Florida International University FIU Digital Commons

$11-15-2017$

\title{
The Bible Against American Slavery: Anglophone Transatlantic Evangelical Abolitionists' Use of Biblical Arguments, 1776-1865
}

Richard Rodriguez

Florida International University, rrodr103@fiu.edu

DOI: $10.25148 /$ etd.FIDC004052

Follow this and additional works at: https://digitalcommons.fiu.edu/etd

Part of the African American Studies Commons, Biblical Studies Commons, Christianity Commons, Intellectual History Commons, Religious Thought, Theology and Philosophy of Religion Commons, and the United States History Commons

\section{Recommended Citation}

Rodriguez, Richard, "The Bible Against American Slavery: Anglophone Transatlantic Evangelical Abolitionists' Use of Biblical Arguments, 1776-1865" (2017). FIU Electronic Theses and Dissertations. 3511.

https://digitalcommons.fiu.edu/etd/3511 


\section{FLORIDA INTERNATIONAL UNIVERSITY \\ Miami, Florida}

\section{THE BIBLE AGAINST AMERICAN SLAVERY: ANGLOPHONE \\ TRANSATLANTIC EVANGELICAL ABOLITIONISTS’ USE OF BIBLICAL ARGUMENTS, 1776-1865}

A dissertation submitted in partial fulfillment of the requirements for the degree of DOCTOR OF PHILOSOPHY

in HISTORY

by

Richard Rodriguez 
To: Dean John F. Stack, Jr.

Steven J. Green School of International and Public Affairs

This dissertation, written by Richard Rodriguez, and entitled The Bible Against

American Slavery: Anglophone Transatlantic Evangelical Abolitionists' Use of Biblical Arguments, 1776-1865, having been approved in respect to style and intellectual content, is referred to you for judgment.

We have read this dissertation and recommend that it be approved.

$\begin{array}{r}\text { Alexandra Cornelius } \\ \hline \text { Noble David Cook } \\ \hline \text { Erik Larson } \\ \hline \text { Jenna Gibbs, Major Professor }\end{array}$

Date of Defense: November 15, 2017

The dissertation of Richard Rodriguez is approved.

Dean John F. Stack, Jr.

Steven J. Green School of International and Public Affairs

Andrés G. Gil

Vice President for Research and Economic Development and Dean of the University Graduate School

Florida International University, 2017 
C Copyright 2017 by Richard Rodriguez

All rights reserved. 


\section{DEDICATION}

To my dear wife Debonaire, whose encouragement and patience was vital to my ability to finish this work. 


\section{ACKNOWLEDGMENTS}

I am grateful and blessed to have completed my graduate studies at Florida International University. From working on my master's thesis to my dissertation, my understanding of abolitionism transformed from a narrowly-focused project on divine retribution for slavery, to how abolitionists used the Bible to challenge the whole system of American slavery. The evolution of this dissertation, and my studies, has been a profound learning experience. I appreciate the intellectual and moral support of Florida International University's History Department. I owe so many people thanks for helping me along the way and encouraging my topic. Kenneth Lipartito and Alex Lichtenstein first saw my potential and encouraged me to apply for doctoral studies while I studied in the Miami-Dade Public Schools Teaching American History (TAH) master's cohort. Alexandra Cornelius was first to help me understand that I had a viable topic. Josue Rey was a great example as a teaching assistant in the TAH program and a supportive friend. Elizabeth O'Kane Lipartito provided sound editing advice on writing graduate level papers.

No dissertation can be attempted, however, without a rigorous study of the historiography of the field of chosen study. For that I can thank none other than my dissertation director, Jenna Gibbs. Her mentorship and commitment to the project and its improvement, and my growth as a scholar, will never be forgotten. I am also indebted to the other members of my committee, Alexandra Cornelius, Noble David Cook and Erik Larson. It has been my privilege to work with and learn from such a distinguished panel. I look forward to their continued advice to take this dissertation, and my work, to the next level. 
I would like to thank my classmates in the Florida International University's History Department. There is something about taking classes together, discussing big ideas, lending a helping hand and reading our papers to each other that sharpens the mind and humbles the heart. Fellow students like René Silva, Lindsey Maxwell, Sven Kube, and Tiffany West, are among others who I respected as fellow travelers willing to lend their help and support.

I am particularly grateful to my Creator for the ability to write this dissertation. And I am indebted to my dear wife Debonaire, and my children: Jade, Daniel, Stephen, and Kris for cheering me on to complete the task. My physical and spiritual family provided any spark I needed to continue this journey and I will always be thankful for them. 


\author{
ABSTRACT OF THE DISSERTATION \\ THE BIBLE AGAINST AMERICAN SLAVERY: ANGLOPHONE \\ TRANSATLANTIC EVANGELICAL ABOLITIONISTS' USE OF BIBLICAL \\ ARGUMENTS, 1776-1865 \\ by
}

Richard Rodriguez

Florida International University, 2017

Miami, Florida

Professor Jenna Gibbs, Major Professor

This dissertation argues that transatlantic abolitionists used the Bible to condemn American slavery as a national sin that would be punished by God. In a chronological series of thematic chapters, it demonstrates how abolitionists developed a sustained critique of American slavery at its various developing stages from the American Revolution to the Civil War. In its analysis of abolitionist anti-slavery arguments, "The Bible Against Slavery" focuses on sources that abolitionists generated. In their books, sermons, and addresses they arraigned the oppressive aspects of American slavery. This study shows how American and British abolitionists applied biblical precepts to define the maltreatment of African Americans as sins not only against the enslaved, but also against God. The issues abolitionists exposed to biblical scrutiny, and that are analyzed in this dissertation, correlate with recent scholarly treatments of American slavery.

American slavery evolved in the period bracketed by the American Revolution and the Civil War. From 1790 to 1808 American slavery transitioned from reliance on the international slave trade to a domestic market. Abolitionists' anti-slavery arguments 
likewise transitioned from focusing on the maltreatment of the immigrant, widow and orphan, to a focus on the proliferation of the sexual exploitation of women and the destruction of African American families. Abolitionists challenged every evolutionary step of American slavery. They argued that slavery was responsible for the destruction of American cities and the split of the British Empire during the crisis of the Revolution. They also denounced the constitutional compromises that protected slavery for 78 years, they challenged its spread westward, decried its dehumanization and sexual exploitation of African Americans, and its destruction of African American families. They galvanized a generation of women anti-slavery activists that launched the feminist movement. Abolitionists' prediction, meanwhile, that divine retribution would come remained constant. Abolitionists produced such a prodigious body of biblical anti-slavery literature that by the Civil War, their arguments were echoed among northern pastors and even President Abraham Lincoln. 


\section{TABLE OF CONTENTS}

CHAPTER

PAGE

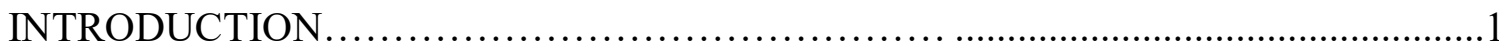

CHAPTER I. The American Revolution as Divine Retribution for Slavery ...................11

CHAPTER II. American Slavery, the Constitution and the Bible...................................53

CHAPTER III. American Slavery, the Bible and Westward Expansion .........................81

CHAPTER IV. George Bourne, the Bible and the Roots of Nineteenth-Century

Immediate Abolitionism.................................................. 105

CHAPTER V. The African American Voice, the Bible and American Slavery ............141

CHAPTER VI. Immediate Abolition, the Bible and Women......................................171

CONCLUSION. The Civil War as Divine Retribution for American Slavery................222

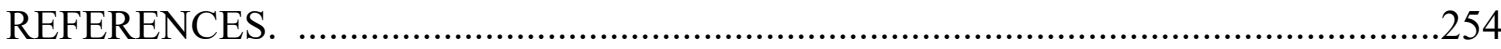

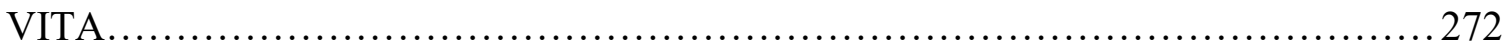




\section{INTRODUCTION}

150 years ago, as the Civil War drew to a close in March of 1865 and casualties surpassed 850,000 men and the war cost eclipsed the $\$ 1.4$ trillion mark, ${ }^{1}$ Abraham Lincoln intimated to the American people that perhaps, "God wills that [the war] continue until all the wealth piled by the bondsman's two hundred and fifty years of unrequited toil shall be sunk, and until every drop of blood drawn with the lash shall be paid by another drawn with the sword..."2 In short, he feared that the war was divine retribution for slavery. Lincoln was not the first head of state to dread divine retribution for slavery; Thomas Jefferson had shared this premonition. ${ }^{3}$ Nor was the Civil War the first cataclysmic event that drove opponents of slavery to invoke divine punishment, as this scripturally inspired rhetoric dated back to the American Revolution in 1776.

Historians have generally agreed that evangelical opponents of slavery figured prominently in the transatlantic debates over slavery. ${ }^{4}$ Yet, no full-length work has

\footnotetext{
${ }^{1}$ Charles R. Cooper, Chronological And Alphabetical Record of the Engagements of the Great Civil War With the Casualties On Both Sides And Full And Exhaustive Statistics And Tables of the Army And Navy, Military Prisons, National Cemeteries, Etc., Etc., Milwaukee, Wis.: The Caxton press, 1904, 313-314, Hathi Trust Digital Library, (accessed September 30, 2017); Sven Beckert, The Monied Metropolis: New York City and the Consolidation of the American Bourgeoisie, 1850-1896 (Cambridge, UK: Cambridge University Press, 2001), 117.

${ }^{2}$ Abraham Lincoln, Second Inaugural Address; endorsed by Lincoln, April 10, 1865, March 4, 1865; Series 3, General Correspondence, 1837-1897; The Abraham Lincoln Papers at the Library of Congress, Manuscript Division (Washington, DC: American Memory Project, [2000-02]) ; URL: http://www.ourdocuments.gov/doc.php?flash $=$ old \&doc $=38$ (accessed December 1, 2015).

${ }^{3}$ Thomas Jefferson quoted in Gary L McDowell and Sharon L. Noble, Reason and Republicanism: Thomas Jefferson's Legacy of Liberty (Lanham: Rowman \& Littlefield, 1997), 285.

${ }^{4}$ David Brion Davis, The Problem of Slavery in Western Culture (Ithaca, N.Y.: Cornell University Press, 1966), 292; Christopher Leslie Brown, Moral Capital: Foundations of British Abolitionism (Chapel Hill: Published for the Omohundro Institute of Early American History and Culture, Williamsburg, Virginia, by the University of North Carolina Press, 2006), 174-75; James D Essig, The Bonds of Wickedness: American Evangelicals against Slavery, 1770-1808 (Philadelphia: Temple University Press, 1982).
} 
explored the recurrent scriptural trope in evangelical abolitionist discourse of how the fear of God and his divine retribution informed and drove Anglophone transatlantic abolitionists to lobby against and ultimately abolish the slave trade in the British Empire. Moreover, despite a plethora of work on proslavery advocates' biblical argumentation, there is very little intellectual scholarship of British and American evangelical abolitionists' biblical argumentation that rejected American slavery and its ancillary institutions and warned of divine retribution in the form of war, civil war, famine, or pestilence. This study offers a sustained analysis of how Anglophone transatlantic evangelical abolitionists used the Bible to argue against slavery and, in the process, invoke the idea of divine retribution between 1776 and 1865.

This study of how evangelical abolitionists used the Bible to oppose slavery makes crucial historiographical contributions. Historians like David Brion Davis and Christopher Brown have woven a transatlantic tapestry of the concerted effort between abolitionists on both sides of the Atlantic. ${ }^{5}$ But despite the richness of their work and that of others, analysis of antislavery theological thought is largely wanting. An exception is John Coffey's “Tremble Britania!,” which traces the idea of divine retribution in the writings and speeches of Anglophone transatlantic abolitionists, but is limited to the British context. ${ }^{6}$ Similarly, the transatlantic evangelical revivalism of the eighteenth and

\footnotetext{
${ }^{5}$ David Brion Davis, Inhuman Bondage: The Rise of Fall of Slavery in the New World (New York City, NY: Oxford University Press, 2006); David Brion Davis, The Problem of Slavery in the Age of Revolution, 1770-1823 (Ithaca, N.Y.: Cornell University Press, 1975); David Brion Davis, The Problem of Slavery in the Age of Emancipation (New York: Alfred A. Knopf, 2014); Christopher Leslie Brown, Moral Capital: Foundations of British Abolitionism (Chapel Hill: Published for the Omohundro Institute of Early American History and Culture, Williamsburg, Virginia, by the University of North Carolina Press, 2006).

${ }^{6}$ John. Coffey, Aug. "“Tremble Britannia!': Fear, Providence and the Abolition of the Slave Trade, 17581807,” English Historical Review, Vol. CXXVII, No. 527 (Oxford University Press, 2012).
} 
nineteenth centuries that was fertile ground for abolitionism is capably covered by, among others, Roger Anstey and Richard Carwardine. ${ }^{7}$ Yet these admirable histories dwell neither on the theological underpinnings of evangelical abolitionism nor the fear of divine retribution as a driving motivation. The historiography of the development of African American folk Christianity also provides a pivotal framework for how African Americans developed their own antislavery theology even as they converted to the chief religion of the land of their oppressors. Albert Raboteau and Eddie Glaude Jr., for example, both demonstrate the ways that African American evangelical antislavery activists, both male and female, used the "Black Jeremiad" to address slavery. ${ }^{8}$ Yet little scholarship has examined black evangelical abolitionists' use of biblical arguments in juxtaposition to that of whites. This project further offers a remediating counter to the abundant scholarship of proslavery argumentation and activism -- like that of Mark Noll and Molly Oshatz -- by instead bringing to light the opposing antislavery biblical arguments made by evangelicals. ${ }^{9}$ Finally, scholarship by Keith Bradley and Jennifer Glancy detailing slavery as it was in the time of Christ informs this dissertation to show that, despite eighteenth- and nineteenth-century pro-slavery advocates' protestations to the contrary, there was a stark difference between the slavery in the time of Christ and

\footnotetext{
${ }^{7}$ Roger Anstey, The Atlantic Slave Trade and British Abolition, 1760-1810 (Atlantic Highlands, N.J.: Humanities Press, 1975); Richard Carwardine, Transatlantic Revivalism: Popular Evangelicalism in Britain and America, 1790-1865, (Westport, Conn: Greenwood Press. 1978).

${ }^{8}$ Albert Raboteau, Slave Religion: The "Invisible Institution" in the Antebellum South (New York: Oxford University Press, 1978); Eddie Glaude Jr., Exodus!: Religion, Race, and Nation in Early NineteenthCentury Black America (Chicago, Illinois: University of Chicago Press, 2000).

${ }^{9}$ Mark Noll, The Civil War as a Theological Crisis (Chapel Hill: University of North Carolina Press, 2006); Molly Oshatz, Slavery and Sin: The Fight against Slavery and the Rise of Liberal Protestantism (New York: Oxford University Press, 2012).
} 
American slavery in the eighteenth and nineteenth centuries. ${ }^{10}$ More broadly speaking, the histories of slavery and the slave trade also form important contextual backdrops, as do the histories of the American Revolution and the Civil War, which caused so much of the crisis, dislocation, upheaval, and destruction that abolitionists pointed to as the divine consequences of what they saw as the iniquity of slavery.

\section{Overall Argument}

In their protests against American slavery, abolitionists from both sides of the Atlantic posited a biblical antislavery message that progressed over time along with the institution, between the American Revolution and the advent of the immediatist abolitionist movement. In that time, they listed how the institution violated scripture while simultaneously harming its victims - the enslaved Africans. They also warned that American slavery was detrimental to the nation because, as a national sin, it left the nation liable to divine retribution. Though this biblical antislavery argument can be traced from the time of the Quakers through the end of the Civil War, particular attention is given to the years between the revolutionary period of 1776 and leading up to 1837 with the advent of the immediatist abolition movement and its engagement of women. The study concludes with a fast-forward look into how biblical antislavery arguments were reprised during the Civil War by abolitionists, pastors, and even Abraham Lincoln, to explain the cataclysm of war as divine retribution for slavery.

The study of the ways in which British and American evangelicals used the Bible to confront American slavery reaches beyond an understanding of the activities of the abolitionists against an oppressive system and provides several key insights. First, the

\footnotetext{
${ }^{10}$ Keith Bradley, Slavery and Society at Rome (Cambridge [England]: Cambridge University Press, 1994); Jennifer Glancy, Slavery in Early Christianity (Oxford: Oxford University Press, 2002).
} 
Bible was influential of the world-views, teachings and arguments of evangelical antislavery activists. Abolitionists were motivated by the authority the Bible held in their lives and the fear of God it generated from their reading of it. For example, Granville Sharp stated in his introduction that he was basing his argument on scripture and that he was writing a "warning" to Great Britain and its Colonies.

Second, evangelical antislavery activists applied the teachings of the Bible to speak to and critique the American brand of slavery and its ancillary institutions and to define them as sins against God worthy of divine retribution. Evangelical abolitionists likened the condition of the enslaved African to the unjust treatment of the poor, the widow, the fatherless and immigrants. They made the case that Africans met all four criteria and as such were afforded special protection by God in the form of divine retribution. They also argued that American slavery was an unprecedented form of oppression that exceeded forms that had been on biblical record as being punished by God. They biblically affirmed the egalitarian message of the Declaration of Independence that "all men are created equal," while they used the scriptures to challenge the dehumanizing compromises of the Constitution that legalized the subjugation of African Americans. Moreover, they argued that the American Constitution's allowance for masters to retrieve their slaves anywhere in the Union and subsequent Fugitive Slave Laws legislated oppression for they violated biblical limits of a master's authority over slaves. They argued that the slave trade, both international and domestic, dehumanized Africans and destroyed families while violating scriptural mandates on the sanctity of marriage and family. They posited that women were particularly at risk and reduced to forced concubinage and prostitution thus systematically violating biblical moral 
standards. They exposed the system of American slavery as an institution that violated God's moral laws. By advancing these varied arguments, the biblical arguments of the abolitionists awakened the moral outrage of a generation of antislavery activists who formed the first national Antislavery Society to fight against American slavery. They also motivated a large contingent of women, largely from the North, and a few key women from the South, that were ready to contend on behalf of their black sisters in bondage. These women formed the genesis of suffragist movement and the modern-day Women's movement.

Third, over 90 years, a rich library antislavery literature based on the Bible developed that from which abolitionists and pastors invoked to make sense of the Civil War. Abolitionists and pastors reprised and updated arguments used during the American Revolution that the war was divine retribution. Evangelical abolitionists made this argument in the highest levels of American government including Congress. Indeed, as the Civil War was ending, Abraham Lincoln conjectured about the link between the war and divine retribution for slavery.

\section{Organization of Chapters}

Chapter 1-1776-The American Revolution as Divine Retribution: Abolitionists on both sides of the Atlantic argued from the Bible that American slavery was a national sin that called for national repentance. With the Quakers' biblical antislavery arguments serving as an antecedent, Samuel Hopkins and Granville Sharp pointed to the Revolutionary War as divine retribution for slavery for both America and Great Britain. Samuel Hopkins responded to the Continental Congress request for national repentance by asserting that American slavery, and particularly the slave trade, was the sin to be 
confessed and repented of for God to give victory to the American colonies. Sharp, likewise, argued that the Revolutionary War was a civil war and as such, according to scripture, was a form of divine retribution for slavery—particularly on Great Britain.

Chapter 2-1787- The Constitution, American slavery and the Bible:

Abolitionists on both sides of the Atlantic, Hopkins and Sharp, argued from the Bible that the newly ratified Constitution codified slave measures (i.e. the slave trade and fugitive slave laws) that were in violation to biblical commands against the oppression of the poor, the widow and the immigrant. Thus, they predicted future divine retribution for American slavery.

Chapter 3-1789-1812- American slavery, westward expansion, and the Bible: Abolitionists from both sides of the Atlantic argued that the expansion of American slavery, especially through the slave trade, would put the nation at risk. David Rice, Thomas Branagan and David Barrow argued that American slavery violated scripture and that its expansion westward was harmful to both its victims and the new republic. These arguments were made post the ratification of the Constitution, leading up to and in the aftermath of the St. Domingue and the Louisiana uprisings. Abolitionists described the particular ways that American slavery morally and adversely impacted enslaved women and the African American family.

Chapter 4-1812-1818 - The Biblical Roots of the Immediatist Movement:

George Bourne, a Presbyterian preacher from Great Britain, emerged as a seminal protagonist in the immediatist abolitionist movement when he developed a framework for his biblical opposition to American slavery. While in Virginia he confronted slaveholders and barred them from his congregation and thus came into conflict with the Presbyterian 
Church. In 1816 he published his The Book and Slavery Irreconcilable, in which he attacked gradual emancipation and introduced his central argument that American slavery should be immediately abolished because it was "manstealing," and therefore a violation of biblical commands against stealing. As a violation of scripture, Bourne posited that American slavery was a national sin and must be immediately abolished to avoid divine retribution.

Chapter 5-1829-1832-The Black voice, American slavery and the Bible: In 1829 the black abolitionist voice emerged, even before the American Antislavery Society (AASS) was established in 1833. David Walker and Maria Stewart were outspoken opponents of American slavery and predicted divine retribution for slavery. They framed their arguments in biblical language and references. Walker predicted the U.S. would turn against itself in internecine war due to slavery.

Chapter 6-1833-1837-The Immediatist and Woman's Movement and the Bible: George Bourne became a key protagonist in the nascent immediatist movement as he advanced his biblical argument against American slavery. He helped influence William Lloyd Garrison's conversion from a proponent of gradual emancipation and later joined him and others to form the AASS. Bourne's book, The Book and Slavery Irreconcilable, was republished as A Picture of Slavery by the newly established AASS in 1833. Seeking to duplicate the success of women in the British antislavery movement, the two men sought to engage women in the American movement. In next books, Bourne payed pointed attention to how American slavery violated scripture while exploiting enslaved women and their families. His biblical arguments helped galvanize northern, largely evangelical women, to join the antislavery movement. Other key women, Sarah 
and Angelina Grimke, former slaveholders, joined and added their biblical abolitionist arguments to the movement.

Conclusion-American slavery, the Civil War and Divine Retribution: Between 1837 and 1865 other abolitionists made biblical arguments against American slavery. By the time the Civil War began in 1861, northern pastors joined abolitionists in using the Bible to interpret the times and to console the grieving nation. As the war ended, abolitionists addressed Congress to interpret the war as divine retribution for slavery. When Abraham Lincoln delivered his second inaugural address at the end of the war in 1865 , he had a large body of biblical antislavery literature from which to draw inspiration to frame the cataclysm of the Civil War in biblical terms, enough to suggest that the Civil War was divine retribution for slavery.

\section{Methodology}

This study used the Gale Cengage Learning Slavery and Antislavery

Transnational and Sabin Americana Databases to find and analyze printed and published pamphlets and books from the Revolutionary Era through to the Civil War, as well as other printed and published matter. The study was organized around the works and activities of key protagonists, both male and female, and on both sides of the British Atlantic. This dissertation covered their arguments against American slavery through six chronological stages bracketed by the American Revolution and the Civil War. Within this chronological schema, the study focused on four key themes of evangelical biblical discourse: the slave trade, the slave codes governing slaves' behavior and punishments, the Fugitive Slave Acts that mandated that Northerners return escaped slaves to their Southern owners by law and the maltreatment to African American women and their 
families in general due to the domestic slave trade. Throughout, the dissertation explores how the Anglophone abolitionists used the Bible to teach and argue that American slavery was particularly offensive to God, and tracks how these transatlantic abolitionists lobbied those in the highest levels of authority to abolish slavery lest the nation suffer the wrath of God. 


\section{CHAPTER I}

\section{The American Revolution as Divine Retribution for Slavery}

In 1776 in Newport, Rhode Island, Samuel Hopkins wrote his appeal to the Continental Congress to cease slavery and the slave trade. Looming just offshore was what he believed to be the judgment of God against his city, state and fledging nation. British warships had taken up positions opposite Newport in 1775 and were laying siege to the city with a sustained fuselage aimed at destroying this major port of trade. Many of the Newport residents were forced to evacuate and stay away for three years. Chief among Newport's imports were kidnapped African people sold into the American slave market. Hopkins believed the importation of slaves to be the cause of God's wrath and the British bombardment to be providential evidence of that. On these grounds, he appealed to the Congress to abolish slavery, which he believed to be the cause of God's wrath. ${ }^{1}$ In opposition to a system of slavery that deemed and maintained Africans should be a debased people condemned to inhuman bondage antislavery advocates like Hopkins and Granville Sharp focused on the social condition of the African slaves, protested against their maltreatment, and made Biblical arguments that their oppression as widows, orphans and immigrants was a sin that provoked God's wrath. They maintained that both the United States and Great Britain were under divine retribution as evidenced by the crisis of war.

The British invasion of the United States that Hopkins witnessed was a transnational manifestation of an empire in crisis. Two nations, who were formerly a part

\footnotetext{
${ }^{1}$ Joseph A. Conforti, Samuel Hopkins and the New Divinity movement: Calvinism, the Congregational Ministry, and reform in New England between the Great Awakenings (Grand Rapids, MI: Christian University Press, 1981), 131-32.
} 
of the British Empire, were at once tearing away from each other while forcefully advancing their conflicting agendas. The ensuing rupture of the British-American Empire was of transatlantic and transnational proportions. In the midst of this conflict and crisis emerged two antislavery prophets who tied the crisis to the interposition of providence. These antislavery prophets, Hopkins and Sharp, proclaimed to their respective nations that the crisis of war engulfing their nations, and the empire at large, was due to divine retribution for slavery. Still both sides had clear issues prompting them into the conflict. The Revolutionary War was initiated by Great Britain in response to patriot intransigence fueled by a special brand of revolutionary ideology of natural rights and equality. Through pamphlets, letters, books, sermons, and newspaper editorials Americans repeatedly voiced their displeasure until it erupted into a series of spontaneous and planned physical demonstrations of open defiance and rebellion. Americans were responding to a decade of British parliamentary decisions they believed were unfair, not representative of their interests, and lacked their consent. Americans increasingly suspected and complained that the British sought to reduce them to political and economic slavery. The Declaration of Independence summarized the sum of British villainies, American defiance to British rule and their desire to stand free and clear among other nations. ${ }^{2}$

The revolutionary rhetoric of the Declaration of Independence, however, proved to be a double-edged sword. While it staked the American claim that American colonists were created and born equal to their British counterparts and had the right to freely

\footnotetext{
${ }^{2}$ Bernard Bailyn, The ideological origins of the American Revolution (Cambridge, Mass: Belknap Press of Harvard University Press, 1967), vi-vii, ix-x, 152-155.
} 
pursue their aspirations, it also exposed the inconsistency of the American cause. Antislavery sympathizers noted the duplicity of Americans who complained of political and economic slavery at the hands of the British while holding Africans in bondage. Several works have made the case that the revolutionary rhetoric complicated notions of African American inferiority. Noted patriots loudly made the case on behalf of African Americans for their right to equality and freedom. Benjamin Rush and Thomas Paine were pointed in their position that American slavery stood athwart to the principles of natural rights upon which patriots made their case against Great Britain. Rush accused Americans of committing "a national crime" against African Americans while Paine publicly wondered about the temerity of American slaveholders who "complain so loudly of attempts to enslave them, while they hold so many hundred thousand in slavery?"3 These antislavery advocates were among those willing to appropriate the language of natural rights on behalf of and in application to the African slaves. ${ }^{4}$

While revolutionary rhetoric and rebellion created occasions for the same principles to be applied to Africans, it also served as a catalyst for the British invasion

\footnotetext{
${ }^{3}$ Benjamin Rush, An Address to the Inhabitants of the British Settlements in America on Slavekeeping (Philadelphia, 1773), 25; Thomas Paine, African Slavery in America (1775), in Human Rights Reader: Major Political Writings, Essays, Speeches, and Documents from the Bible to the Present, ed. Micheline Isha (New York: Routledge, 1997), 130-33 cited in Jenna M. Gibbs, Performing the Temple of Liberty: Slavery, Theater, and Popular Culture in London and Philadelphia, 1760-1850 (Baltimore: Johns Hopkins University Press, 2014), 21.

${ }^{4}$ David Brion Davis, The Problem of Slavery in the Age of Revolution, 1770-1823 (Ithaca, New York: Cornell University Press, 1975), 48-49, 164, 255, 259; Gary Nash and Jean Soderland, Freedom by Degrees: Emancipation in Pennsylvania and its Aftermath (New York : Oxford University Press, 1991), xii; 77-79; David Waldstreicher, Runaway America: Benjamin Franklin, slavery, and the American Revolution (New York: Hill and Wang, 2004), x; J.R. Oldfield, Transatlantic abolitionism in the age of revolution: an international history of anti-slavery, c.1787-1820 (Cambridge; New York : Cambridge University Press, 2013), 14-15; Seymour Drescher, Abolition: a history of slavery and antislavery (Cambridge: Cambridge University Press, 2009), 115.
} 
and the subsequent American Revolution. The crisis that ensued due to that war further complicated American slavery as it triggered dislocations to the institution and the slave trade, even if they would ultimately be followed by booming growth. ${ }^{5}$ Before the war, American slavery was bolstered by the British Empire. ${ }^{6}$ That protection, however, collapsed when Britain invaded and both sides were forced to offer emancipation to Africans who fought in their respective armed forces. During the war Americans felt vulnerable to slave insurrections and slave fugitives. ${ }^{7}$ Furthermore, the international slave trade was suspended by the Continental Congress as hostilities with Great Britain commenced..$^{8}$

Northern states began to pass gradual abolition laws as Pennsylvania and Massachusetts led the way before the war ended. Pennsylvania took the unprecedented first step among the northern states to pass gradual abolition laws in 1780 . The act signaled the first time that any American legislative body abolished racial slavery-even if gradually. ${ }^{9}$ Massachusetts followed in 1781 and 1783 with a series of court decisions in favor of Quok Walker and Elizabeth "Mumbet" Freeman that appealed to the newly ratified state constitution that made slavery unconstitutional. ${ }^{10}$ Soon after the war other

\footnotetext{
${ }^{5}$ George Van Cleve, A slaveholders' union: slavery, politics, and the constitution in the early American Republic (Chicago: University of Chicago Press, 2010), 7, 18-19.

${ }^{6}$ Van Cleve, Slaveholders' union, 3.

${ }^{7}$ Van Cleve, Slaveholders' union, 18.

8 http://www.constitution.org/bcp/res non-import.html, (accessed 3/29/16); https://www.history.org/Almanack/life/politics/resolves.cfm (accessed 3/29/16).

${ }^{9}$ Gary B. Nash and Jean R. Soderland, Freedom by Degrees: Emancipation in Pennsylvania and Its Aftermath (New York: Oxford University Press, 1991), 99.

${ }^{10}$ Christopher Cameron, To Plead Our Own Cause: African Americans in Massachusetts and the Making of the Antislavery Movement (Kent, Ohio: Kent State University Press, 2014), 73-74.
} 
northern states followed suit. The Rhode Island General Assembly passed a gradual emancipation law in 1784 and in 1787 the state also dismantled the very source of their economic success when they outlawed the slave trade. ${ }^{11}$ The loss of the slave trade caused Rhode Island to never recover its economic prowess. ${ }^{12}$ Connecticut also passed a gradual emancipation law in $1784 .{ }^{13}$ In this respect, the American Revolution and its rhetoric had an impact on slavery in much of the northern states.

Besides the dislocation of American slavery, the American Revolutionary crisis also provoked declarations by abolitionists like Hopkins and Sharp of providential displeasure and divine retribution for slavery and its potential risk to both the American republic and the British Empire as a whole. Recent scholarship has demonstrated how Sharp warned that slavery and the slave trade placed the British Empire at risk. ${ }^{14}$ American slavery, being a part of the British Empire before the war, also came under Sharp's scrutiny. But while Sharp's role in warning both the British and the American colonies of how their involvement with slavery placed the empire at risk of divine retribution has been explored; Sharp's biblical rationale has not received due attention. Likewise, Hopkins, Sharp's transatlantic counterpart and ally, crafted a similar biblical argument for his American countrymen that slavery and the slave trade placed the young American republic at risk. While Sharp warned the American colonies of divine

\footnotetext{
${ }^{11}$ David Brion Davis, The Problem of Slavery in the Age of Revolution, 1770-1823 (Ithaca and London: Cornell University Press, 1975), 26.

${ }^{12}$ Van Cleve, Slaveholders' union, 18.

${ }^{13}$ Ibid.

${ }^{14}$ Christopher Leslie Brown, Moral capital: foundations of British abolitionism (Chapel Hill: Published for the Omohundro Institute of Early American History and Culture, Williamsburg, Virginia, by the University of North Carolina Press, 2006), 160-161.
} 
retribution, he did so by addressing them as a part of the British Empire. Hopkins agreed with Sharp that the American Revolution was divine retribution. He addressed Americans, however, as citizens of a fledgling republic seeking its independence from Great Britain. Regardless of their views of empire versus republic, the two men's' shared reverence for the moral authority of the Bible and their use of scripture along with the ideology of human rights, transcended their differences. Without first consulting each other, they each argued that the American Revolution was divine retribution for slavery.

Abolitionist warnings of divine retribution for slavery did not begin with Hopkins and Sharp and can be traced to the writings of the Quakers Anti-slavery Quakers like Ralph Sandiford, Benjamin Lay, John Woolman and Anthony Benezet all opposed American slavery and wrote sustained critiques of the institution. They were, each in different ways, very specific in their contention that God was a defender of the poor and would not tolerate their oppression by the rich. They argued that God would judge any nation that exploited its poor as Americans did through their system of slavery. They warned of a future "day of vengeance" and they used the Bible as their authority. They each warned and wrote that divine retribution would come because of American slavery in the form of wars, famines and pestilence and they used the Bible as their basis of argument. Moreover, they chided their fellow Quakers to consider what they would do if God decided to "visit" their nation with divine retribution for mistreating people whom God created. ${ }^{15}$ Sandiford, for one, warned his fellow Quakers in his 1730 polemic The

${ }^{15}$ Ralph Sandiford, The mystery of iniquity; in a brief examination of the practice of the times, by the foregoing and the present dispensation: whereby is manifested how the Devil works in the mystery, which none can understand and get the victory over but those that are armed with the light ... Unto which is added in the postscript, the injury this trading in slaves doth the commonwealth, humbly offer'd to all of a publick spirit. The second edition, with additions. [Five lines of Scripture texts]. [Philadelphia], anno 1730, 


\section{Mystery of Iniquity; in a brief Examination of the Practice of the Times that God}

"delivered" poor people in the past by working to "frustrate their Enemies, and afflict the Nations at that time with the Sword abroad, and Fire and Pestilence, and Dissentions at home..."16 Shortly after, Lay warned of divine retribution for slavery in the American colonies. In his All Slave-keepers that keep the Innocent in bondage apostates Lay urged his contemporaries to set their slaves free. He believed they should do so in order that God might "secure" them when "the Scourge shall come" in "life or death." He further warned Americans to "quit their hands of them before it is too late" for he believed that "a Day of Vengeance will come." ${ }^{17}$ Woolman decried the hunting of fugitive slaves. He appealed to a passage in Deuteronomy 23:15-16. "If a stranger sojourn with thee in your land," Woolman declared, "ye shall not vex him; but the stranger that dwelleth with you shall be as one born amongst you, thou shall love him as thyself." ${ }^{18}$ And he asked his

55-56, Slavery and Anti-Slavery, Gale, Florida International University (accessed Mar. 25, 2016); Benjamin Lay, All slave-keepers that keep the innocent in bondage, apostates pretending to lay claim to the pure \& holy Christian religion; of what congregation so ever; but especially in their ministers, by whose example the filthy leprosy and apostacy is spread far and near; it is a notorious sin, which many of the true Friends of Christ, and his pure truth, called Quakers, has been for many years, and still are concern'd to write and bear testimony against; as a practice so gross \& hurtful to religion, and destructive to government, beyond what words can set forth, or can be declared of by men or angels, and yet lived in by ministers and magistrates in America. The leaders of the people cause them to err. Written for a general service, by him that truly and sincerely desires the present and eternal welfare and happiness of all mankind, all the world over, of all colours, and nations, as his own soul; Benjamin Lay, Philadelphia, 1737 [i.e., 1738], 5, 119, 179; Slavery and Anti-Slavery, Gale, Florida International University, (accessed Mar. 25, 2016); John Woolman, Considerations on the keeping of Negroes : recommended to the professors of Christianity of every denomination. Tract Association of Friends (Series); no. 85. Philadelphia, [18--?], 4, Slavery and Anti-Slavery, Gale, Florida International University, (accessed Mar. 25 2016); Anthony Benezet, A caution and warning to Great Britain and her colonies, in a short representation of the calamitous state of the enslaved Negroes in the British dominions: collected from various authors and submitted to the serious consideration of all, more especially of those in power by Ant. Benezet, Philadelphia, 1766, 12, Slavery and Anti-Slavery, Gale, Florida International University, (accessed Mar. 25, 2016).

${ }^{16}$ Sandiford, Mystery of Iniquity, 55.

${ }^{17}$ Benjamin Lay, All slave-keepers [...] apostates, 119, 179.

${ }^{18}$ Woolman, Considerations on Keeping of Negroes, 3, 6. 
fellow Quaker a series of haunting questions: "What shall we do when God riseth up? And when he visitheth, what shall we answer him? Did not he that made us, make them? And did one fashion us?" 19 Perhaps most widely known and most often quoted of the Quaker abolitionists was Benezet. ${ }^{20}$ Benezet utilized the book of Exodus to draw a parallel between the Africans in bondage to the Israelites enslaved in Egypt. Observing in his $A$ Caution and Warning published in 1766, Benezet posed a comparative question to Americans: "Will not the groans," Benezet asked, "of this deeply afflicted and oppressed people reach Heaven..."21

Quaker theology did not automatically prohibit the slave trade or slaveholding. Most of its leaders had interests in slaveholding before 1750 and hence were hostile to antislavery rhetoric. ${ }^{22}$ It was such a leadership that Sandiford and Lay faced when they opposed the institution among Quakers. The predominantly slaveholding Quaker leadership vehemently opposed Sandiford for what he wrote and censured him because he published his polemic without their permission. Quaker leadership was even more outraged by Lay in 1738 when he also rebuked and warned a predominantly slaveholding leadership of divine retribution for slavery. Like Sandiford, Lay was disciplined for his antislavery position as well as for his unorthodox methods. He was expelled by the

\footnotetext{
${ }^{19}$ Woolman, Considerations on Keeping of Negroes, 6-7.

${ }^{20}$ Christopher Leslie Brown, 2006, Moral capital: foundations of British abolitionism. Chapel Hill: Published for the Omohundro Institute of Early American History and Culture, Williamsburg, Virginia, by the University of North Carolina Press, 391.

${ }^{21}$ Anthony Benezet, A caution and warning, 12.

22 Jean Soderland, Quakers \& Slavery: A Divided Spirit (Princeton, N.J.: Princeton University Press, 1985), $32,35,166-167$.
} 
Quakers and became an outcast. By the time Woolman and Benezet began to advocate against slavery the Quakers' leadership had changed and more amenable to antislavery rhetoric, which helps explain why Woolman and Benezet, despite also being stridently opposed to slavery and warning of divine retribution, never faced the censure of their fellow Quakers' Meeting. The transition from a slaveholding majority leadership to a leadership critical of slavery facilitated their efforts to encourage the Quakers to be done with slavery by $1776 .^{23}$

As the Quakers were cleansing themselves of slavery in 1776, Americans at-large found themselves under siege as Great Britain sought to suppress rebellion in the colonies. Boston and New York had already been invaded, and Rhode Island, where Hopkins lived, was now under attack. As each port city was attacked by the British, residents fled in droves to the countryside. The Continental Congress was shaken by the invasion of the British in Boston and New York and sent out an urgent distress signal to all of the colonies on March 16, 1776. Their statement is instructive because it hits on nascent American national values. Many Americans, determined to throw off the British and build their own nation, had by now developed a deep sense of patriotism and republican zeal. Also, having been influenced by the first transatlantic evangelical revival known as the First Great Awakening, many Americans were amenable to providential language. Congress' statement prominently features all of these elements:

In times of impending calamity and distress; when the liberties of America are imminently endangered by the secret machinations and open assaults of an insidious and vindictive administration, it becomes the indispensable duty of these hitherto free and happy colonies, with true penitence of heart, and the most reverent devotion, publickly [sic] to acknowledge the over ruling providence of

${ }^{23}$ Soderland, Quakers \& Slavery, 32, 35, 166-167; Nash \& Soderland, Freedom by Degrees, 89. 
God; to confess and deplore our offences against him; and to supplicate his interposition for averting the threatened danger, and prospering our strenuous efforts in the cause of freedom, virtue, and posterity. ${ }^{24}$

This urgent congressional call reveals the enormous pressure Americans felt as they stared at "impending distress" in the form of the British invasion. Leading up to the American Revolution colonists already believed they faced the "secret machinations" of their parent country. But now, with the Royal navy descending upon them in waves, they braced themselves for the "open assaults of an insidious and vindictive administration." This bulletin also provides insight into what Americans believed they were fighting for. Americans believed that the British invasion was a direct assault to "the liberties of America." Congress therefore responded by urgently calling American patriots in the thirteen colonies to pray to God for help in this hour of crisis. Such a call would have resonated with religiously enthusiastic American colonists who were concerned about the survival of the maiden republic. Yet the Congress was not merely calling for a nominal day of prayer and fasting. It was challenging the American colonists, as their "indispensable duty," to "with true penitence of heart, and the most reverent devotion, publickly [sic] to acknowledge the over ruling providence of God." Americans in the early republic tied providential and biblical language to political culture, and here it is evident that the Continental Congress was openly calling for the new and emerging nation to call on God and acknowledge his rule and providence in a time of crisis. American patriots believed that God would protect them from the imposing oppressor that was Great Britain if they would come to him in prayer.

\footnotetext{
${ }^{24}$ Journals of the American Congress from 1774 to 1788 (Washington: Way and Gideon, 1823), Vol. I, pp. 286-287] published in http://www.shadesofgrace.org/2010/05/04/americas-founders-proclamations-forfasting-and-prayer/ (accessed 4/30/16).
} 
Acknowledging God's sovereignty, however, was not enough to save the republic and protect American liberties. Congress also urged the colonists "to confess and deplore our offences against him." If the American people were to pray to God and acknowledge his providential sovereignty over the affairs of nations he would respond. They should also confess their sins against him, so he would forgive them. By restoring a righteous relationship with God they would be in a better position "to supplicate his interposition for averting the threatened danger." American patriots believed that their cause against the British was as righteous as David's cause was against the stronger Goliath, thus Congress also asked for prayers that God would prosper "our strenuous efforts in the cause of freedom, virtue, and posterity." Yet despite their belief that their cause was right, it is clear from this all-points bulletin that Congress felt a sense that they were in grave danger. Hopkins would have been among those who received this urgent call for prayer and try his hand at a fitting response to Congress.

Hopkins was converted by Jonathan Edwards in the context of the First Great Awakening, but he did not learn abolitionism from the renowned evangelist. Indeed, Edwards was a slave owner who defended slavery. Yet, over time, Hopkins became an avid antislavery opponent, as he reflected on the key tenets of his mentor's theology on disinterested benevolence while in Newport, Rhode Island, a major colonial slave port. ${ }^{25}$ He came from humble beginnings, born on a farm in Waterbury Connecticut on September 21, 1721 and was a hardworking and conscientious young man while growing up. By the time he was 14 he began to consider the direction of his life and opted for the

\footnotetext{
${ }^{25}$ Conforti, Samuel Hopkins and the New Divinity Movement, 12.
} 
ministry. He thus decided on an education at Yale to prepare himself. ${ }^{26}$ At Yale he came in contact with Jonathan Edwards and began to seriously look at his life in the light of scripture. There, he was influenced by the powerful preaching of the likes of Edwards, Gilbert Tennant and George Whitefield. Hopkins and other students heard fiery sermons by itinerants who preached extemporaneously without notes. The revival meetings pushed students like Hopkins to evaluate his own religious experience and conversion. Hopkins soon began to feel his own sense of guilt, sinfulness, and need for salvation. After much contemplation, Hopkins deepened his commitment to God. ${ }^{27}$ He also developed a close relationship with Jonathan Edwards. Hopkins accepted Edwards' invitation to be his understudy in Northampton, Massachusetts and there joined Edwards' "school of the prophets," and withdrew from his ministerial studies at Yale. Under Edwards's tutelage Hopkins grew into one of the most well-known of the New Divinity preachers to be trained for the ministry during the Great Awakening. ${ }^{28}$ As a part of the New Divinity faction Hopkins had joined the faction of the Congregationalist denomination open to the revivalism, as opposed to the Old Light party. ${ }^{29}$ Hopkins also became very familiar with Congregationalist doctrine and Consistent Calvinist orthodoxy, while he became Edwards' confidant. After his ordination he accepted a position as minister at the Second Congregational Church of Sheffield, Connecticut. ${ }^{30}$

\footnotetext{
${ }^{26}$ Ibid, 18-21.

${ }^{27}$ Ibid, 26-27.

${ }^{28}$ Ibid, 24-25, 29-30, 33-40.

${ }^{29}$ Ibid, 2.

${ }^{30} \mathrm{Ibid}, 25-37,45$.
} 
Hopkins gained more than preparation for licensure and ministry in his two years at Edwards's Northampton parsonage; he also gained his trust. Later, during a time when Edwards had settled in Stockbridge for eight years to serve at an Indian mission, Edwards's and Hopkins's friendship deepened so much so that after Edwards death in 1757 Edwards's family asked to finish his life's work, particularly his dissertation concerning the Nature of True Virtue. While editing Edwards' work, Hopkins made some key corrections designed to discourage abstraction and emphasize concrete social action. After making the changes, he published True Virtue in 1765. Hopkins's emphasis on social action in his edition of True Virtue became part of his special theology, "Hopkinsianism," which prepared him to advocate for enslaved Africans when he moved to Newport, Rhode Island after losing his position at Sheffield, Connecticut. While closing out his affairs, he sold his slave and accepted a position the same year at Newport, Rhode Island, the hub of the New England slave trade. ${ }^{31}$ At Newport, Hopkins came face to face with the slave trade, which provoked his social activism and pushed him further away intellectually from his mentor, Edwards, who - like Hopkins himself had been a slave owner. For six years he witnessed the heart wrenching sight of chained Africans disembarking and peddled at the Newport slave market. Hopkins heard the horrid accounts of human trafficking from Africa that included disease and death and he was horrified by stories of cruelty and bloody slave insurrection on the Atlantic. The more Hopkins learned the more he became convinced that the slave trade was a sin

\footnotetext{
${ }^{31}$ Edwards A. Park, "Memoir of the Life and Character of Samuel Hopkins," in Sewall Harding (ed.), The Works of Samuel Hopkins, D.D. (3 v., Boston, 1854), 114 in Schultz, "The Making of a Reformer," 354.
} 
against God and humanity. ${ }^{32}$ By the time of the Revolution, he had the moral conviction to write and publish A Dialogue Concerning the Slavery of the Africans. ${ }^{33}$

When Samuel Hopkins wrote to Congress in 1776, in response to their call for public prayer and confession, he defined slavery as sin for which the republic must repent to save the republic. Hopkins was among those making haste plans to flee when he paused enough to read and consider Congress' urgent call. He agreed that the British invasion had origins of a providential source and had a good idea about what he believed to be the sin to be confessed and renounced. Believing slavery was a sin and the main cause of the British invasion, he urged Congress to renounce it. Being a patriot, American liberty meant a lot to Hopkins. He fully supported the Continental Congress and addressed them as "fathers of these Colonies." He was among the many Americans who believed that theirs was a "noble struggle for Liberty." Hopkins believed that the cause of the Colonies, "who are under such a degree of oppression and tyranny," was righteous as they had been "reduced to the most abject state of bondage and political slavery, without just cause" at the hands of the British Empire. ${ }^{34}$ Hopkins, however, also believed that African slavery was the sin and cause of their "distressed land." And he and many fellow Newport residents could point directly to the agents of that "distress" in the form of British warships. The British had laid siege to the Newport slave harbor in 1775 and

\footnotetext{
${ }^{32}$ Conforti, Samuel Hopkins and the New Divinity Movement, 126.

${ }^{33}$ Samuel Hopkins, Timely Articles on Slavery (1854; Mnemosyne Publishing Inc., 1969), iv.

${ }^{34}$ Samuel Hopkins, A dialogue concerning the slavery of the Africans : shewing it to be the duty and interest of the American states to emancipate all their African slaves : with an address to the owners of such slaves : dedicated to the honourable the Continental congress : to which is prefixed, the institution of the Society, in New-York, for promoting the manumission of slaves, and protecting such of them as have been, or may be, liberated ... Hazard pamphlets ;v. 70, no. 3 Norwich [Conn.], 1776, iii-iv, Slavery and Anti-Slavery, Gale, Florida International University, (accessed Mar. 25, 2016).
} 
were pummeling the city so terribly that Hopkins and many other Newport residents were evacuating. When they did return three years later, they found a city badly damaged by the British. In that violent and calamitous context Hopkins wrote his response in $1776 .^{35}$

Challenging the highest level of American leadership over the issue of slavery, however, was not a well-received message. Slavery was legal in all the thirteen colonies. ${ }^{36}$ The Continental Congress included an influential slaveholding voting block. ${ }^{37}$ Anyone challenging slavery had to know that the chances of persuading Congress to get rid of slavery were slim at best. Thomas Jefferson found that to be the case when his antislavery tirade in the original draft of the Declaration was edited out by his colleagues in the Congress. ${ }^{38}$ Hopkins faced a slaveholding leadership in some ways similar to the Quaker leadership that Ralph Sandiford and Benjamin Lay faced in the 1730s when they made their antislavery arguments. The key difference, though, was the rhetoric that permeated revolutionary times, as reflected in the Declaration of Independence in 1776, provided an entry for those like Hopkins who would challenge slavery in a very direct manner. Furthermore, Congress's call for prayer and confession provided Hopkins the opportunity to fashion his biblical argument against slavery, which incorporated notions of natural law. Revolutionary times also provided a sense of patriotism that allowed Hopkins to argue that his antislavery was in fact a way to save the new nation from

\footnotetext{
${ }^{35}$ Conforti, Samuel Hopkins and the New Divinity Movement, 131-32.

${ }^{36}$ George William Van Cleve, "Founding a Slaveholders' Union, 1770-1797," In Contesting Slavery: The Politics of Bondage and Freedom in the New American Nation, edited by Hammond John Craig and Mason Matthew, 117-37, University of Virginia Press, 2011 http://www.jstor.org.ezproxy.fiu.edu/stable/j.ctt6wrnj6.11,121 (accessed 6/18/16).

${ }^{37}$ Kenneth Morgan, Slavery and servitude in colonial North America: a short history (Washington Square, N.Y.: New York University Press, 2001), 105.

${ }^{38}$ Morgan, Slavery and servitude, 105.
} 
destruction before it even had a chance to develop. Thus, Hopkins was able to tie the British invasion to antislavery arguments, the Bible, natural law and the survival of the maiden republic all in one fell swoop.

The Congressional call for national prayer candidly acknowledged the belief in the role of providence in the young republic's belief system. As such, Hopkins' argument that Great Britain's invasion was a manifestation of providential divine retribution for slavery was not rejected immediately out of hand. Congress had, after-all called for the American people to "acknowledge the over ruling providence of God." Hopkins, however, took it a step further. He posited in his Dialogue Concerning the Slavery of the Africans that the invasion was a result of divine retribution for the sin of slavery. $\mathrm{He}$ argued that Americans were committing a sin against God by holding Africans in bondage and that God was punishing America for that sin. In a direct response to the congressional call "to confess and deplore our offences against him" Hopkins asserted that "the slavery in which we hold the blacks is wrong" and was a "very great and public sin; and therefore a sin which God is now testifying against in the calamities he has brought upon us..." ${ }^{39}$ And for Hopkins, American slavery was certainly a sin to be "deplored" by all Americans. Addressing the congressional call "to supplicate his interposition for averting the threatened danger" Hopkins argued that this sin had to be "reformed, before we can reasonably expect deliverance, or even sincerely ask for it." 40 Here, Hopkins gently pointed out that it would be delusional for Americans to expect God to help them when they were blatantly sinning against him by holding others in

\footnotetext{
${ }^{39}$ Hopkins, Dialogue, 5-6.

${ }^{40}$ Hopkins, Dialogue, 6.
} 
bondage. He compared the crisis in Newport to that of Egypt as recorded in the book of Exodus, and referenced how God dealt with Pharaoh and the Egyptians for their oppression of the Hebrew slaves and wondered aloud whether "it may be well worthy our serious consideration, whether we have not reason to fear the hand of God, which is now stretched out against us..."41

Hopkins based his argument to Congress on biblical passages used to identify sinful practices that needed to be confessed and reformed because they brought with them warnings of divine retribution. Congress, had after all, called on the people to publicly acknowledge and confess their sin. For Hopkins, the first sin Americans were creating was the use slaves' labor against their will and without payment. Quoting Jeremiah Hopkins wrote: "Woe unto him that buildeth his house by unrighteousness, and his chambers by wrong; that useth his neighbours service without wages, and giveth him not for his work!" 42 The term "Woe" in this case is a dreadful warning of divine retribution and was applied to warn of the consequences of not paying laborers their wages. Second, he invoked the injunctions in the Bible against the maltreatment of the poor, the immigrant and the fatherless (and their proscribed divine punishments) and applied them to the case of Africans being enslaved in the American colonies. "Be intreated [sic] also seriously to consider," Hopkins wrote, "how very offensive to God unrighteousness, and the oppression of the poor, the stranger and fatherless, is represented to be in the holy scripture. This is often spoken of as the procuring cause of the calamities that came on

\footnotetext{
${ }^{41}$ Ibid, 33.

${ }^{42}$ Hopkins, Dialogue, 37; Holy Bible, Jeremiah 22:13.
} 
God's professing people of old, and of their final ruin." ${ }^{\text {43 }} \mathrm{He}$ expanded his argument by extensively using biblical precedent and scriptural warnings that God is the protector of the oppressed who promises to punish all those who oppress others. To make his point, Hopkins cited the scripture in Jeremiah 21:12. "O house of David, thus saith the Lord, Execute judgment in the morning, and deliver him that is spoiled out of the hand of the oppressor, lest my fury go out like fire, and burn that none can quench it because of the evil of your doings. ${ }^{" 44}$ Hopkins also cited other biblical passages with a similar warning of divine retribution for the maltreatment and oppression of the poor, the needy and the immigrant. For example, quoting Ezekiel, Hopkins wrote, "The people of the land have used oppression, and exercised robbery, and have vexed the poor and needy: yea, they have oppressed the stranger wrongfully. And I sought for a man among them, that should make up the hedge, \&c. - but I found none. Therefore have I poured out mine indignation upon them,' \&c." [sic $]^{45}$ This scriptural quote is particularly telling because it provides a hint as to what drove abolitionists like Hopkins who used the Bible to argue against American slavery: it posits the notion that God looks unsuccessfully for a person "that should make up the hedge" or "stand in the gap," as it were, and be a watchman to warn the people of God's wrath for sin. Abolitionists like Hopkins sought to be prophets who warned people in their time, as the prophets in the biblical record had warned the Israelites, that their oppression of the poor and needy would not go unpunished.

\footnotetext{
${ }^{43}$ Hopkins, Dialogue, 58.

${ }^{44}$ Ibid, 58.

${ }^{45}$ Ibid.
} 
Rhode Island's economy, like the rest of the American colonies, had become dependent on the commodification of Africans. Hopkins, therefore, sought to demonstrate to Congress that the British invasion was God's punishment for the commodification of human beings and he would make further use of other biblical examples. Quoting the book of Amos 2:6, Hopkins wrote, "Thus saith the Lord, for three transgressions of Israel, and for four, I will not turn away the punishment thereof, because they sold the righteous for silver, and the poor for a pair of shoes." 46

Abolitionists like Hopkins maintained that the selling of the "righteous" or those who did nothing deserving such treatment and the trafficking of "the poor," meaning those without the means to protect themselves from such treatment, would cause God to "not turn away the punishment thereof." Hopkins' use of the scriptures demonstrates that he had a wealth of biblical references that he believed could be used as injunctions against the commodification of Africans. Hopkins included the citation of Zechariah 7:9 in his polemic. "Thus speaketh the Lord of hosts," Hopkins wrote, "saying, Execute true judgment, and shew mercy and compassions every man to his brother. And oppress not the widow, nor the fatherless, the stranger nor the poor, and let none of you imagine evil against his brother in your heart. But they refused to hearken — yea, they made their hearts as an adamant stone-Therefore came a great wrath from the Lord of hosts.' \&c." $[\mathrm{sic}]^{47}$ This biblical reference shows that despite repeated pleas to "oppress not the widow, nor the fatherless, the stranger nor the poor..." the people refused to change and even dug themselves deeper in their systematic oppressions of the poor. "Therefore,"

\footnotetext{
${ }^{46} \mathrm{Ibid}, 58$.

${ }^{47}$ Ibid, 59.
} 
Hopkins warned, "came a great wrath from the Lord of hosts." Hopkins argued that divine retribution came as a result of the maltreatment of the poor, widows, the fatherless and immigrants.

Hopkins, and evangelical abolitionists like him, thus viewed the Africans held in bondage, not as people cursed to perpetual slavery, but rather as a population of poor, widowed and orphaned immigrants who, according to the scriptures, were afforded special divine protection even to the point of divine retribution. He thus opposed American slave-owning colonists and the existing slave codes that established American slavery according to "the condition of the [African] mother." ${ }^{48}$ Hopkins focused on the social condition of the African slaves and protested against their maltreatment. He argued that God protected those who were in vulnerable social conditions and applied these scriptures to the Africans. "Are not the African slaves," Hopkins proclaimed, "among us the poor, the strangers, the fatherless, who are oppressed and vexed, and sold for silver? And will not God visit and punish such oppression?"49 Abolitionists who used the Bible to condemn American slavery argued that the Africans were God's creation and were, as strangers, orphans and widows, populations that God had specifically warned to be held harmless and protected—lest his wrath be aroused.

Hopkins and abolitionists like him dreaded the "visitation" and the punishment of God who they believed was bent on defending the rights of the poor, the widows, orphans, and immigrants. Hopkins did not merely see a mass of black people in enslaved Africans. Instead, he saw diverse populations mixed in one whole people that were at

\footnotetext{
${ }^{48}$ John C. Hurd, The law of freedom and bondage in the United States (New York: Negro Universities Press, 1968), 228, 232, 233, 299, 303.

${ }^{49}$ Hopkins, Dialogue, 59.
} 
once poor, widowed, orphans and aliens in a new nation. Enslaved Africans, bereft of any means of supporting themselves, without clothing, food or shelter besides what was provided to them by their captors, were clearly poor. Men and women who had once been married yet forcibly separated from their spouses when captured, kidnapped, and sold into the slave trade were effectively left widowed. Children kidnapped from their parents were essentially orphaned. All Africans forcibly taken from their continental home were strangers and immigrants in a new land. In just about every way, once Africans entered the grind that was American slavery, they were reduced to a vulnerable population primed for exploitation. Slave owning colonists and the governing slave codes applied only to Africans and condemned them to inhuman bondage. Abolitionists like Hopkins, therefore redefined the population by focusing on their social conditions to reveal a special population afforded divine protection due to their vulnerable circumstances.

Yet, despite Hopkins' appeal and Congress's public call for public repentance of sin, Congress was not ready to define American slavery as sin, much less abolish it. They were not willing to go beyond the non-importation agreement in the Declarations and Resolves issued on October $14,1776 .{ }^{50}$ Congress was made of white men with property which included property in humans. As Sandiford, Lay or even Jefferson would find, the notion of getting rid of the livelihood of powerful slave owners was a non-starter. ${ }^{51}$ While northern states slowly began to entertain debates to end slavery even before the war ended, the southern states, save for Virginia which had spirited debates on emancipation,

\footnotetext{
${ }^{50} \mathrm{http}$ ://www.constitution.org/bcp/res non-import.html (accessed Mar. 29, 2016); https://www.history.org/Almanack/life/politics/resolves.cfm (accessed Mar. 29, 2016).

${ }^{51}$ Morgan, Slavery and servitude, 105.
} 
were not as eager to give up the lucrative institution. ${ }^{52}$ Great Britain's Royal Navy and armed forces, meanwhile, eventually made it ashore and invaded Newport in December of 1776 and inflicted such damage that the town never recovered its former prominence. ${ }^{53}$

Other antislavery sympathizers besides Hopkins associated the British invasion and destruction of cities with divine retribution for slavery. For example, when Charleston, South Carolina was devastated by British artillery, Abigail Adams observed the dense smoke from across the bay and wondered if Charleston was "like Sodom" and speculated that it was because of the "sin of slavery" that this calamity had come upon Charleston. ${ }^{54}$ Adams' choice of Sodom and Gomorrah as a metaphor to interpret what happened to Charleston is interesting on a few levels. First, Sodom's destruction, as described in the book of Genesis, notes that Abraham observed "dense smoke rising from the land, like smoke from a furnace. ${ }^{" 55}$ Perhaps that smoke caused Adams to recall Sodom and Gomorrah and make the comparison. Also, according to the book of the prophet Ezekiel, the sin of Sodom was that they were "arrogant, overfed and unconcerned; they did not help the poor and needy." ${ }^{56}$ These connections to crisis as divine retribution for slavery were similar to Hopkins' connections to the maltreatment of the poor as a causal factor of divine retribution. Other active abolitionists, like Benjamin

\footnotetext{
${ }^{52}$ Christopher Brown, Moral Capital: Foundations of British Abolitionism (Chapel Hill: University of North Carolina Press, 2006), 414.

${ }^{53}$ Samuel Greene Arnold, History of the state of Rhode Island and Providence plantations (Spartanburg, S.C.: Reprint Co., 1859), 446-47.

54 Carp, Rebels Rising, 217.

${ }^{55}$ Holy Bible, Genesis 19:28, New International Version, 2011.

${ }^{56}$ Holy Bible, Ezekiel 16:49, New International Version, 2011.
} 
Rush, also associated the destruction of a city as divine retribution for slavery. Observing what the British had done to Philadelphia, Pennsylvania, he remarked that it was "purification" from $\sin ^{57}$ Similarly, Ezra Stiles, referring to Newport, believed "God [brought the] severest calamities of this civil war upon the maritime town..." 58

Across the Atlantic, Granville Sharp was just as convinced as Hopkins that the law of divine retribution was playing out on American soil. As Great Britain was striking the colonists at the onset of the Revolutionary War, Sharp wrote a 360 page jeremiad to that effect, one that started on a blistering note and never let up in its prosecutorial tone. But even as Sharp wrote his treatise on slavery, Great Britain was in the midst of selfscrutiny about its role as an empire. Britons had taken great pride in their supposed role as advocates of freedom. Fond of comparing themselves to their rivals in Spain, Britons conceived themselves to have built their empire by allowing Native Americans and their American colonists the space to practice their own beliefs. ${ }^{59}$ Unlike Spain who had supposedly annihilated Native Americans and enforced their monolithic Catholic orthodoxy, England believed they had done little more than push Native Americans into their own space and had not forced Anglican orthodoxy on the American colonists. ${ }^{60}$ The American Revolution, however, raised questions about the egalitarian nature of their empire as Americans railed about the trampling of their rights as citizens of the empire. Moreover, even on the mainland, some British subjects were shaken as defeat and the

\footnotetext{
${ }^{57}$ Carp, Rebels Rising, 217.

${ }^{58} \mathrm{Ibid}, 216$.

${ }^{59}$ Brown, Moral Capital, 155.

${ }^{60}$ Ibid.
} 
loss of the American colonies loomed. British ministers began to wonder aloud if the empire was in need of repentance and if God opposed the empire. One such minister was David Grant, the Anglican Reverend from the Church in Edinburgh. "Trusting too much in the arm of flesh; loaded with national guilt; scarce ever considering the superintendency of heaven, we have met alas! disappointment, where we expected success; loss, where we expected gain; shame where we expected honor. Anxiety in every breast at home; rage and resentment abroad; poverty and decline of trade; property in a sinking, staggering and fluctuating condition, all proclaim aloud the judgments of heaven."

As the American Revolution entered its second year, Sharp warned and argued that Great Britain and her American colonies had lost their way as an empire and was at a crosshairs with God. And just as Hopkins used the Bible to make his point, Sharp also relied heavily on scripture to craft his argument that God was inflicting punishment for their maltreatment of the poor and their complicity in slavery and the slave trade. The opening salvo set the tone for what followed:

"The People of the Land have used Oppression, and exercised Robbery, and have vexed the Poor and Needy: yea, they have OPPRESSED THE STRANGER WRONGFULLY," \&c. "Therefore have I poured out mine Indignation upon them," \&c. Their OWN WAY have I recompensed upon their Heads, saith the Lord God." Ezek. xxii. 29-31 [sic] ${ }^{62}$

\footnotetext{
${ }^{61}$ David Grant, The Living Manners of the Times, and Their Consequences; Together with the Motives to Reformation; a Sermon Preached in the Tolbooth Church of Edinburgh, on Tuesday the $9^{\text {th }}$ of February 1779; Being the Day Appointed for a General Fast, and Printed at the Desire of Several Who Heard it (Edinburgh, 1779), 19 cited in Brown, Moral Capital, 184-185.

${ }^{62}$ Granville Sharp, The law of retribution, or, A serious warning to Great Britain and her colonies : founded on unquestionable examples of God's temporal vengeance against tyrants, slave-holders, and oppressors ... London, 1776, title page, Slavery and Anti-Slavery, Gale, Florida International University (accessed Mar. 29, 2016).
} 
Thus begins Sharp's explosive The Law of Retribution, an extensive jeremiad against slavery, published in 1776. Summoning the strongest Old Testament language, Sharp rebuked his own nation and issued a serious warning that God's indignation was pouring out upon the people of the land. Imbued with the prophet's righteous indignation Sharp applied Ezekiel's equation that vexing the poor, the needy and the stranger equated with robbery and oppression. The civil slaughter of the Revolutionary War provided menacing Exhibit A evidence that God was visiting upon Great Britain and the American colonies his recompense for the oppression of Africans. Granville Sharp confronted Great Britain on the basis of two familiar standards. His weapons of choice were the laws of England and the laws of God which he used to help Africans in distress and defend their rights. His two-pronged approach earned him the praise of Thomas Clarkson who called him the "father of the cause in England." 63

Sharp solidified his credentials as an abolitionist by his role in the James Somerset case. In November of 1769 James Somerset was brought to England from Virginia by Charles Stewart, his owner. Somerset attempted to run from Stewart but was apprehended by Stewart and remanded into custody to be shipped and sold into slavery in Jamaica. The desperate Somerset summoned Sharp for counsel on January 13, 1772 who responded with advice and legal aid. Sharp quickly hired a legal team for the distressed Somerset. The case went before Lord Mansfield whose decision freed Somerset. While the 1769 decision provided freedom for Somerset, it did not outlaw slavery in the British Empire. Lord William Murray Mansfield, the presiding judge on the case, was careful to not overrun the rights of slaveholders to benefit from the work of their slaves; however,

${ }^{63}$ Thomas Clarkson, The History of the Rise, Progress and Accomplishment of the Abolition of the SlaveTrade by the British Parliament (New York: John S. Taylor, 1936), 196. 
he did limit their ability to hold them in bondage in England. While it did not abolish slavery, its ambiguity left the impression that England was the land of liberty. ${ }^{64}$ Thus, once a slave reached the shores of England, in the popular imagination they were considered free, even if that was not the intent of Lord Mansfield's decision. ${ }^{65}$ Although the decision was limited, it did inspire public debate about the rights of blacks as well as suits for freedom in Scotland and across the Atlantic in Massachusetts. ${ }^{66}$ Though Sharp did not attend any of the Somerset hearings, his influence was felt throughout by virtue of his financial, intellectual and moral capital and he has been associated with the historic emancipatory Somerset decision ever since. ${ }^{67}$

The Somerset decision coincided with Sharp's evolving thought on the idea of divine retribution for slavery and his role in that decision brought him in contact with Anthony Benezet who became his transatlantic counterpart. Mansfield's Somerset decision gained Sharp notoriety as an advocate of Africans both home and abroad and coincided with his incipient correspondence with Benezet who worked in Philadelphia. Benezet reached out to Sharp in May of 1772 in search of a kindred spirit in the war against the slave trade. He hoped to gain an ally to help him stem the tide of the "unnatural and barbarous traffic." Benezet estimated that the traffic brought well over

\footnotetext{
${ }^{64}$ Brown, Moral Capital, 97.

65 Ibid.

66 Ibid, 99.

${ }^{67}$ Prince Hoare, Memoirs of Granville Sharp, Esq., composed from his own manuscripts and other authentic documents in the possession of his family and of the African Institution by Prince Hoare; with observations on Mr. Sharp's Biblical criticisms, by the Right Rev. the Lord Bishop of St. David's, London, 1820, 69-70, 82, 91, Slavery and Anti-Slavery, Gale, Florida International University (accessed September 6, 2016).
} 
100,000 souls into bondage per year by "the English alone." ${ }^{68}$ More specifically, Benezet hoped to enlist Sharp's assistance to petition the King to inquire into the trafficking of Africans when he uttered a supplication that gave insight into his belief in divine retribution. Believing that the Gospel of Jesus Christ "enjoined [us] to love [Africans] as ourselves," Benezet asked Sharp rhetorically, "What shall we do when God riseth up, and when he visiteth? What shall we answer him?" ${ }^{69}$ Benezet's entreaty revealed what drove him and his deep responsibility for his fellow man. The Gospel of Jesus Christ, to which he had devoted his life, "enjoined" him to love the oppressed Africans as himself and to care for their sufferings as if they were his own. Believing Sharp shared his conviction, he asked the question: what would they do if and when God "visiteth?" What would they do when God called them and their nations to account for the slave trade that had destroyed tens and hundreds of thousands of lives? Sharp was Benezet's kindred spirit when it came to this type of providential thinking. They both feared divine retribution for slavery not only for themselves but also for their respective nations.

Sharp's correspondence with Benezet in the summer of 1772 signaled the next phase of Sharp's evolving struggle against British-American slavery. Sharp announced his new project when he wrote to Benezet,

It is on this account that I have now undertaken to write once more upon the subject, in order to apprise disinterested people of the dangerous tendency of such a measure; and shall endeavor to prepare what few friends I have in Parliament, for an opposition to such a destructive proposal, in case it should be renewed. ${ }^{70}$

\footnotetext{
${ }^{68}$ Anthony Benezet to Sharp, May 14, 1772, in Memoirs, 98-100.

${ }^{69}$ Benezet to Sharp, May 14, 1772, in Memoirs, 99.

${ }^{70}$ Granville Sharp to Anthony Benezet, August 21, 1772, in Memoirs, 101-102.
} 
If the pro-slave West Indies interests were to lobby Parliament on behalf of slavery, Sharp would do some lobbying of his own. Sharp determined to focus on "disinterested people" or people without slave holding interests to "apprise them of the dangerous tendency of such a measure" to legalize slavery in England. Sharp had friends in Parliament who he believed would listen to his appeal. In addition to their friendship, Benezet and Sharp had a certain common ground upon which Sharp made his appeal.

Sharp, however, believed that he must appeal to the Bible as his ultimate authority against slavery. In a letter to Benezet he explained his emphasis on scripture,

My former tracts were built chiefly on the laws of England; but my present work is for the most part founded on Scripture, to obviate the doctrines of some late writers and disputers, who have ventured to assert that slavery is not inconsistent with the Word of God. ${ }^{71}$

Sharp here indicated to Benezet the transition from the wielding of one weapon, the laws of England, to one of a divine nature: Scripture. Sharp, who himself believed in the divine inspiration of the Bible, also believed that his "few friends" in Parliament might also take heed to the Word of God; therefore, he decided to found his next tract chiefly on the Scriptures. Sharp's friends in parliament were high officials of the Church of England who ostensibly were beholden the scriptures and, by law, occupied seats in the House of Lord of Parliament. The Archbishops of Canterbury, York, London, Durham and Winchester held automatic seats in the House of Lords and could possibly lend their influence to the cause.

A grandson of John Sharp the Archbishop of York, Sharp was confident he could at least gain audience with these powerful ecclesiastical officials. ${ }^{72}$ But Sharp needed to

\footnotetext{
${ }^{71}$ Ibid, 101-102.

${ }^{72}$ Hoare, Memoirs, 473.
} 
build a theological case against slavery to earn their respect and cooperation. $\mathrm{He}$ continued explaining himself to Benezet, namely his plan to address the Bishops and clergy, "in order to show them the necessity of uniting their influence and interest on this occasion" In fact, Sharp had taken the opportunity to approach Dr. Drummond, the Archbishop of York who himself was "a zealous advocate for the freedom of the Negroes." ${ }^{73}$ When Sharp approached the Archbishop of York, he reached for the second highest ranking official of the Church of England. The opportunity to persuade such a high ranking official to influence other members of the Clergy represented a fruitful opportunity. Based on his letter to Benezet, Sharp hoped to use his next tract "founded on scripture," to influence at least the ecclesiastical members of Parliament -- and perhaps other MPs -- to stem any attempts to advance slavery in England. The tract itself reveals that Granville Sharp also had in mind to build a theological case for destroying the larger network of the slave trade and slavery itself. His appeal was not only based on the Scriptures, but also promoted urgency to avoid the "destructive" nature of BritishAmerican slavery.

The emerging conflict with America provoked Sharp into taking a wide angle shot of British-American slavery that framed it as a sin of the empire. Sharp's major arguments were outlined in a pamphlet of 340 pages. The title of the work itself is provocative, if not authoritative. Mostly set in capital letters Sharp unabashedly declared: THE LAW OF RETRIBUTION; OR, A SERIOUS WARNING TO GREAT BRITAIN AND HER COLONIES, Founded on unquestionable Examples of GOD's TEMPORAL VENGEANCE AGAINST Tyrants, Slave-holders, and Oppressors[sic]. Such was his

\footnotetext{
${ }^{73}$ Sharp to Benezet, August 21, 1772, in Memoirs, 101-102.
} 
theological salvo in his debate with proslavery advocates who employed the Bible to justify the oppression of forced slavery. For Sharp, they demonstrated the immediate divine intervention to repay unrepentant nations based on their deeds. He did not merely opine about the ethical insensibility of slavery. He also issued an urgent warning to his countrymen to repent or perish in God's certain punishment for the oppression of Africans. Sharp maintained that Jehovah punished nations for oppressing the poor and the stranger. And Great Britain, along with its American colonies, could likewise expect similar recompense for its treatment of Africans, who, for Sharp (as for Hopkins), were poor strangers in the realm of their oppressors.

Sharp appealed to divine authority when challenging his nation to dismantle its apparatus of oppression. He called slavery a "National Crime of the most aggravating kind" and predicted that "according to the usual course of God's Providence in the World" it would "probably draw down some exemplary vengeance upon the unrepenting Inhabitants of this Island!" [sic $]^{74}$ Sharp wasted little time and attacked England's highest lawmaking body in the opening paragraph of The Law of Retribution. Parliament, according to Sharp, had for "near a century" abetted the African slave trafficking apparatus that effected "the monstrous destruction of the Human Species." 75 The inhabitants of England were not the only ones incurring God's wrath for slavery. According to Sharp, the British Colonies and their "uncharitable practice of Slaveholding, especially in the West-India Islands and the more Southern colonies" were also

\footnotetext{
${ }^{74}$ Sharp, Law of Retribution, 1.

${ }^{75}$ Ibid.
} 
at risk. ${ }^{76}$ Without explicitly naming proslavery advocates, Sharp noted that "several attempts that have lately been made to justify these branches of abominable National Iniquity by the Holy Scriptures" had "induced" him to "collect, from the History of the Jews in the several Books of the Holy Scripture, some plain examples of God's Vengeance upon that particular nation, expressly for this kind of Oppression...” Sharp wanted to "prove that Slavery was ever detestable in the sight of God..." "Therefore, wrote Sharp, "speedy Reformation is absolutely necessary...if we mean to entertain the least hope of escaping a severe National Retribution..."77

Sharp's vision of divine retribution went beyond national borders. He believed that the Revolutionary War was not just divine retribution for Great Britain, he also believed that the conflict was a civil war within an empire with transatlantic borders. For Sharp the conflict was among brothers with common British roots who were tied together since the earliest British settlers in Jamestown. Sharp maintained that repentance was necessary in both England and the American colonies, and pointed to "our present Civil Dissensions and horrid mutual Slaughters of National Brethren" that "seem ready to burst upon us!" ${ }^{, 78}$ As Sharp put pen to paper the British Empire was rapidly pursuing a crisis of war. The mainland American colonies were chafing under British rule and were ready to declare their independence. The Crown, equally resolute, hastened to bring the upstart Colonies to heel with an invasion in 1775. Each side had well thought out bellicose prerogatives. Sharp, however, saw the rumblings of war as the gathering of dark clouds

\footnotetext{
${ }^{76}$ Ibid.

${ }^{77}$ Ibid, 3.

${ }^{78}$ Ibid.
} 
pregnant with divine retribution for slavery: Jehovah was beginning his visitation on the British-American Empire and Sharp interpreted the perilous times for his countrymen. For both Sharp and Hopkins, the coming conflict was a civil war. ${ }^{79}$ The empire and its colonies had turned to internecine war and British subjects, all with a common heritage were killing each other on the battlefield. For Sharp this was a sign that God was turning the empire against itself as punishment for its oppression of Africans. Like Hopkins, Sharp compared the possible fate of England and the American colonies with that of Egypt, only he cited the Book of Isaiah. Writing about countrymen he believed to be "deluded" he challenged them to "compare our present national condition" with "the horrible debasement of the Egyptians..." God, according to Isaiah, pronounced judgment on the oppressive Egyptians and declared "I (the Lord, or Jehovah) will set THE EGYPTIANS against THE EGYPTIANS: and they shall fight every one against his Brother, and every one against his Neighbour; City against City, (and) Kingdom against Kingdom. And the Spirit of Egypt shall fail in the midst thereof; and I will destroy the council thereof!' Isaiah xix. 2, 3"80 Egypt had long been synonymous with oppression because of the story of Moses and the Exodus of the Israelites out of Egyptian bondage, recorded in the book of Exodus. By citing the scripture in Isaiah about God turning oppressive Egypt against Egypt, Sharp tied the Revolutionary War, a war between British subjects, directly into his argument that God was punishing Great Britain and Americans for their oppression of Africans. For Sharp, Great Britain and the American colonies were in the midst of a brand of divine retribution that Egypt was said to have suffered by the

\footnotetext{
${ }^{79}$ Hopkins, Dialogue, 47.

${ }^{80}$ Sharp, Law of Retribution, 226.
} 
Prophet Isaiah. Sharp's tract was a warning to his countrymen that they must repent of the sin of slavery to avert the same punishment that befell Egypt.

Like Hopkins and the anti-slavery Quakers, Sharp argued that God took the side of the oppressed against their oppressors. God had "mercy" on the Israelites in the midst of their Egyptian bondage and responded with a vengeance on their behalf against the Egyptians. Great Britain, by virtue of its oppressions of Africans was ominously the modern day equivalent of Egypt. Like previous abolitionists, Sharp referenced the Israelite experience in Egypt by quoting the passage in the book of Exodus,

The children of Israel sighed by reason of the Bondage, and they cried; and their cry came up unto God by reason of the Bondage: and God heard their groaning," \&c. Exod. ii. 23, 24. 'And the Lord said, I have surely seen the Affliction of my People which are in Egypt, and have heard their cry by reason of their Taskmasters: for I know their Sorrows, and I am come to deliver them out of the hand of the Egyptians.' Exod. iii. 7, $8^{81}$

As the story goes, God "heard their groaning" because of their "task-masters" and "knew their sorrows." God then meted out divine retribution on Egypt to deliver the distressed Israelites out of bondage. Believing these examples served as warnings to contemporary nations, Sharp wrote, "the tremendous Judgements [sic] whereby this deliverance was effected (viz. the Plagues of Egypt) are so many signal examples of God's severe Vengeance against Slave-holders, which ought to be had in everlasting remembrance, to warn all Nations of the World against the unnatural and baneful practice of keeping Slaves. ${ }^{" 82}$ For Sharp, what happened to the task-masters in Egypt was exhibit A of what God does to slave holders. Here, he was no longer quibbling with the minutiae of

\footnotetext{
${ }^{81}$ Ibid, 12-13.

${ }^{82}$ Ibid, 13.
} 
whether slavery was legalistically biblical. He was expanding the argument of divine retribution to encompass the transatlantic British Empire to argue that God heard the cries and responded on behalf of those who suffered oppression and bondage to punish the nation which insisted on exacting bondage. Sharp's treatise was a warning to the British Empire that included Great Britain and the American colonies to avoid Egypt's mistake.

Sharp argued that because Africans were in fact strangers and foreigners to the British Empire they must be not oppressed, lest the Empire suffer divine retribution. Africans, as forced immigrants to the transatlantic British Empire, were not citizens nor did they have the rights of citizens. Instead, as an enslaved people, Africans were vulnerable to the laws and codes that reduced them to the status of property by their masters. As foreigners, Sharp argued that Africans were afforded special protection by God. He pointed to the Israelites who were commanded not to oppress strangers in their land Sharp proclaimed the biblical text with his commentary, “'thou shalt not oppress a Stranger: for ye KNOW THE HEART (properly THE SOUL) OF A STRANGER, seeing ye were Strangers in the Land of Egypt.' Exod. xxiii. 9." ${ }^{83}$ God's reminder carried pointed implications. If the Israelites were commanded to remember what it was like to be a stranger, what should that mean to white British-Americans? They had not been the slaves of anyone in the way the Israelites had been in Egypt. The moral here, however, is the standard of compassion that the British-Americans should have toward Africans was the same Israel was commanded to have toward strangers. This also had implications for Americans who complained that they were treated as slaves by Great Britain. If the Americans knew what it meant to be mistreated by Great Britain, should they not also in

${ }^{83}$ Ibid, 15. 
compassion know "the heart of a stranger" when it came to the Africans who they held in bondage? Sharp worked to put into practice the message he preached. Compassion led Sharp to help Somerset and others like him in their distress and help release them from their bondage. Sharp demanded that British and Americans have compassion for strangers as God commanded and he decried the oppression of the Africans who were strangers in their Empire. By framing the question of slavery as a matter of oppression of strangers in the land, Sharp opened a new front in the debate against slavery.

Like Hopkins, Sharp also argued that, besides the stranger, God also forbade the oppression of widows and the fatherless. By this definition Sharp again drove a broadside into the system of slavery and the rationale that upheld it. Again, Sharp pointed to the text, "Thou shalt neither vex a Stranger, nor oppress him; for ye were Strangers in the Land of Egypt. Ye shall not afflict any Widow or fatherless Child. If thou afflict them in any wise, and they cry at all unto me, I will SURELY hear their cry..." ${ }^{84}$ While proslavery advocates would argue that God allowed Israelites to buy and hold foreigners in slavery Sharp argued that God forbade the oppression, affliction or vexing of the stranger in the land. In fact, according to Sharp, God actively heard the cry of the stranger against those who vexed them even if it was at the hands of an Israelite. If God was impartial even to hear the cry of a foreigner against his own people, Sharp argued, what would he do about the cry of an African against the oppressions of British-Americans?

Sharp immediately applied this to the British-Americans: “...(mark this, ye African Traders of this Island, and ye West-India and British American Slave-holders!

\footnotetext{
${ }^{84}$ Ibid, 15-16.
} 
For ye are all guilty of the like abominable Oppressions, and God will SURELY avenge the Cause of the Oppressed)..." 85 Sharp thus challenged British-American slave holders to "mark" the warning of God against the oppressor. Sharp brandished a God who actively defended the rights of the oppressed even to the point of anger. Sharp noted the vengeance of an angry God against anyone who dared oppress the defenseless, "“and my wrath shall wax hot, and I will kill you with the sword, and your Wives shall be Widows, and your Children fatherless.' Exod. xxii. 21 to $24 " 86$ Like Hopkins, Sharp viewed the African slaves as widows, fatherless and strangers - the very populations that are enumerated in the Exodus populations that God protected from oppression. Africans kidnapped into slavery were taken from their families, parents, spouses, children and communities. They thus became widows and fatherless, the very populations God specifically commanded his people not to oppress less his anger be aroused. Sharp, like Hopkins, redefined the contours of the debate by defining the oppressed African slaves in biblical terms.

Sharp's quotation here raises the question of the impact of divine retribution on the American population as a whole. If the American Revolution was indeed divine retribution as Hopkins and Sharp argued, the notion that God's "wrath shall wax hot," and that he would "kill you with the sword, and your Wives shall be Widows, and your Children fatherless" is certainly a haunting use of scripture by Sharp. A form of collateral damage of the American Revolution was the proportionately large number of widows that emerged from the war. According to Dr. Elizabeth O'Kane-Lipartito, approximately 8

\footnotetext{
${ }^{85}$ Ibid.

${ }^{86}$ Ibid.
} 
and 12 thousand women became widows due to the conflict with Great Britain.

Extrapolated to current population figures, that number would equal about one million widows. ${ }^{87}$ While there is no indication that Sharp noted this post-war development, it is a chilling use of scripture to warn British-Americans of divine retribution for slavery.

Sharp also reframed the conversation regarding enslaved Africans by identifying them as the poor, who God commanded should also be protected. Sharp focused on the Crown, Parliament and the leaders of the Church of England as responsible for the impending divine retribution over slavery because they were responsible for oppressive laws in England that exploited the poor through British-American slavery. God was portrayed by Sharp as standing to judge his people over the maltreatment of the poor at the hands of their leaders. Again, he relied on the writings of the Isaiah the Prophet to make his point with commentary. "The Lord," Sharp cried, "standeth up to plead, and standeth to judge the People! The Lord will enter into Judgement with the Ancients' (or Senators) of his People, and the Princes thereof: for you have eaten up the Vineyard; the Spoil of the Poor is in your Houses! What mean you that ye beat my People to pieces, and grind the Faces of the Poor?' saith the Lord of Hosts! Isa. Iii. 13 to 15 [sic]. ${ }^{88}$ This scriptural text, among others, expresses God's command to show kindness and justice to the poor and his promise to hold his people accountable for their oppression of the poor. African bondage at the hands of the British-Americans had a distinct way to "grind

\footnotetext{
${ }^{87}$ Elizabeth O'Kane-Lipartito, “The Misfortunes and Calamities of War”: Civilians and Society in the American Revolution and After, 1775-1830, Unpublished Dissertation, University of Houston, $1993,262$.

${ }^{88}$ Sharp, Law of Retribution, 21.
} 
down" those who found themselves in the grist of its mil. Often overlooked in the late eighteenth century discourse over African slavery, is that, besides being strangers, fatherless, and widows, they were poor. They obviously were not remunerated for their labors, they owned nothing, and had no rights unless they could find someone who would advocate for them. The abusive features of the British-American slave system displayed the base, oppressive realities that the highest leadership in Great Britain had endorsed.

To oppose the British-American slave system Sharp used the writings of the prophets to note that God would surely avenge himself against British-America for the commodification of poor people. He noted that the poor were sold for silver in the time of the Prophet Amos just as Africans were sold for silver in the slave markets in his time. The parallels were striking, and Sharp repeated the rebuke of the Prophet Amos who declared, "The Lord hath sworn by the Excellency of Jacob, surely I will never forget any of these works. Shall not the Land tremble for this, and every one mourn that dwelleth therein?' \&c. Amos viii. 4 to 8 [italics Sharp's] ${ }^{89}$ Like Sharp, the prophet Amos inveighed against the commodification of humans and promised retribution for the maltreatment of the poor. The poor were "swallowed up" and overwhelmed by an apparatus far more powerful then they. The poor could be purchased for silver as if a commodity such as corn or wheat. And Amos proclaimed, as did Sharp to Great Britain and its American colonies, that the Lord had determined that the "land would tremble for this" and widespread "mourning" would result. God would surely mete out judgment,

\footnotetext{
${ }^{89}$ Ibid, 22-23.
} 
Sharp argued, because "surely I will never forget any of these works." $" 90$ The specter of an angry God who would not forget British-American commodification of Africans transcended the issue of slavery beyond the legalistic debate of whether the Old Testament allowed slavery. The weightier question that Sharp posited was: Did God permit the commodification of poor people? The answer according to Sharp's Law of Retribution was that he did not and, again, the Revolutionary War seemed to Sharp to be proof positive that God was angry.

The thought that God heard the cries of the oppressed, and that Africans were crying out for relief from their oppressors sobered Sharp, as it did other abolitionists. The case of Somerset among others who themselves had cried out to Sharp jarred him enough to understand the vexation of African slaves at the hands of their oppressors. The Revolutionary War, and its concomitant "mutual slaughters," signaled to Sharp that God had heard their cries and was taking action against their oppressors. Great Britain and its American colonies were involved in a trafficking network reminiscent of the very oppression that the Bible warned against. "And have not the careless Inhabitants of Great Britain and her [American] Colonies too much reason also to apprehend that the same God," Sharp demanded, "(who professes to hear the cry of oppressed Strangers, if they cry at all unto him) soon or later, visit these Kingdoms with some signal mark of his Displeasure?"91 Sharp charged that the oppression of the Africans was "notorious" for it continued to grind at an "innumerable multitude of poor African Strangers, that are harassed, and continually wearing out, with a most shameful involuntary Servitude in the

\footnotetext{
${ }^{90}$ Ibid.

${ }^{91}$ Ibid.
} 
British Colonies!"92 Regardless of the supposed legalistic permissions permitted for slavery in the Bible, the British-Americans would be hard pressed to argue that BritishAmerican slavery was voluntary for Africans in any way. Africans, who largely did not willingly go into bondage, were clearly afflicted by their condition as slaves.

Like Hopkins, who in his Dialogue addressed the Continental Congress in 1776, Sharp's Law of Retribution, also published in 1776, was an appeal to law makers for the abolition of slavery and the slave trade as the Revolutionary War had begun. As the war progressed he used the document to reach out to the Archbishops and Bishops of the Church of England urging them to "publicly oppose any further encouragement of the slave trade" and was encouraged by many of their commitments to advocate against slavery. ${ }^{93}$ After the war, Sharp's argument that slavery was a sin of the Empire punishable by divine retribution made its way into the public discourse. On the heels of losing the North American Colonies, British clergy voiced the possibility that the loss was due to divine retribution. Charles Crawford, an Antiguan exile, urged that an antislavery bill be brought before the House of Commons "to avert the further indignation of heaven." "94 Gilbert Wakefield, of Liverpool, suggested God raised enemies "to punish our disobedience" vis-à-vis the proper treatment of Africans. ${ }^{95}$ Another Oxford

\footnotetext{
${ }^{92}$ Ibid, 16-17.

${ }^{93}$ Sharp to Dr. John Sharp, March 1779, in Memoirs, 186-7.

${ }^{94}$ Charles Crawford, 1783 quoted by Brown in Moral Capital, 202.

${ }^{95}$ Ibid.
} 
clergyman lamented that "the Western Empire" had been taken and "given to another more righteous than we" who would be committed to "the abolition of slavery." 96

These ideas of national divine retribution for slavery can be traced to Sharp and Hopkins, as the American Revolution began. Hopkins, for his part, in response to an urgent call by the Continental Congress for prayer and supplication for divine intervention in the face of a British invasion, used the opportunity to urge Congress to recognize that American slavery was, based on biblical arguments, a national sin. He argued that American slavery was a sin because it systematically exploited vulnerable people who were poor, orphans, widowed and immigrants and he applied the Bible to show that the exploitation of these populations of people was a sin that God punished. $\mathrm{He}$ also argued that the teachings of Christ required Americans to treat African people as they would want to be treated. Hopkins' argument of equal treatment was bolstered by patriot revolutionary rhetoric that demanded for the respect natural human rights for white American patriots. He argued that if natural rights applied to white American patriots, they also applied to Africans who were also created by God. He urged Congress to immediately release the oppressed Africans in order to gain the favor of God in the contest against Great Britain. His Bible based argument became a template for future abolitionists who would use the scriptures to oppose the system of oppression that was American slavery. As for Sharp, beginning with his use of English law and transitioning into the use of scripture, he had initiated a public awareness that slavery was a national sin with consequences for the British Empire which included the American colonies. His voice, along with the handful of Church of England leaders, would only form part of a

\footnotetext{
${ }^{96}$ Quoted by Brown in Moral Capital, 202.
} 
greater movement made of disparate parts of British society. That movement would slowly but surely gain momentum until the slave trade was abolished from the British Empire in 1807, and slavery itself in the early 1830s. As Thomas Clarkson wrote in his History of the Rise of Abolition of the Slave Trade, Sharp was recognized as the "father of the cause in England" by virtue of what he did and what he wrote. ${ }^{97}$ The antislavery biblical arguments of Anglophone transatlantic abolitionists like Hopkins and Sharp not only argued that the Revolutionary War was divine retribution for slavery and the slave trade, they also later argued that Constitutional compromises with slavery, ratified to exploit Africans in America, would expose the United States to further divine retribution.

\footnotetext{
${ }^{97}$ Clarkson, History of the Rise of Abolition, 57.
} 


\section{CHAPTER II}

\section{American Slavery, the Constitution and the Bible}

When Granville Sharp heard the news, he was bitterly disappointed and aggrieved. A supporter of the American cause, he was now alarmed that the Americans had codified into their Constitution two slave measures that, in his estimation, were offensive to heaven. He fired off a letter to Benjamin Franklin, his correspondent and President of the Pennsylvania Abolitionist Society, to inquire as to how Americans could possibly capitulate to the slave states in their new constitution on the issue of slavery, especially when such measures directly contradicted scripture. Sharp complained Franklin that he was, "sincerely grieved to see the new Federal Constitution stained by the insertion of two most exceptionable clauses." The two "most exceptional clauses" were the 20 year extension of the international slave trade and the fugitive slave law that allowed masters to retrieve their runaway slaves anywhere in the Union. Whether out of embarrassment or ambivalence, Franklin never responded in kind to Sharp. While opponents of American slavery like Sharp and Hopkins were hopeful that the new American nation would purge itself of the stain of human bondage, they did not have the power to influence the outcome of the Constitutional ratification debates. ${ }^{2}$ Nevertheless, they had long gone on record with their biblical opposition to the slave trade and fugitive slave laws. As far as Sharp and Hopkins, as well as others were concerned, the U.S.

\footnotetext{
${ }^{1}$ The second "offending clause" that Sharp referred to here was the one in Article IV, Section 2 of the Constitution which gave slave owners the right to have "delivered up on Claim" to them those "held to Service or Labour [sic]" in their state and had "escap[ed] into another [state]." Northern states would have been hard pressed to gain the support of Southern states without these concessions to their institution of slavery. Granville Sharp to Benjamin Franklin, January 10, 1788, quoted in Hoare, Memoirs of Granville Sharp, 253.

${ }^{2}$ Van Cleve, Slaveholders' Union, 144, 172.
} 
Constitutional Delegation ratified slave clauses that stood athwart to the teachings of the Bible and represented the seeds of impending divine destruction for the United States of America.

It is unclear why Franklin did not respond to Sharp's inquiry, but he did implore his fellow delegates to begin each session with prayer to request providential guidance. He harkened to the early days of the Revolution when the Continental Congress was so "sensible of danger we had daily prayer in this room for divine protection." Franklin reminded the Congress that "Our prayers, sir, were heard and they were graciously answered." He was concerned that now in times of peace "we [have] now forgotten that powerful friend? Or do we imagine that we no longer need his assistance?" Franklin warned his colleagues that they would be considered like "the Builders of Babel: We shall be divided by our little partial local interests." Anticipating the disapproval of future Americans, Franklin cautioned that "we ourselves shall become a reproach and bye word down to future ages." And, predicting future catastrophic ramifications of decisions made in the Convention, Franklin pleaded, "And what is worse, mankind may hereafter from this unfortunate instance, despair of establishing Governments by Human Wisdom and leave it to chance, war and conquest." Franklin closed his appeal with a plea for prayers for "the assistance of Heaven [...] before we proceed to business..."3 The results were not as Franklin hoped as he sadly noted that "The Convention, except ' three or four persons, thought Prayers unnecessary." 4

\footnotetext{
${ }^{3}$ Max Farrand, and David Maydole Matteson, eds., The records of the Federal Convention of 1787, vol. 1 (New Haven: Yale University Press, 1986), 451-452.

${ }^{4}$ Ibid, note on page 452 .
} 
Whether or not the delegates prayed, the Constitution that emerged from the Convention's deliberations contained at least two clauses that did not please Sharp or Hopkins because they ran counter to their published biblical arguments. Despite Sharp's opinion that there were "two most exceptionable clauses" favoring slavery, opinions on the number of slave friendly clauses in the U.S. Constitution vary or if the Constitution was proslavery at all. ${ }^{5}$ As many as five clauses have been identified to be directly related to slavery in the Constitution. ${ }^{6}$ Most historians agree, however, on three: First, the "Fugitive Slave Clause," held that, "No Person held to Service or Labour in one State, under the Laws thereof, escaping into another, shall, in Consequence of any Law or Regulation therein, be discharged from such Service or Labour, but shall be delivered up on Claim of the Party to whom such Service or Labour may be due." Second, the Constitution stated that the slave trade "shall not be prohibited by the Congress prior to the Year one thousand eight hundred and eight." Third, the "Three-Fifths Compromise" allowed the slave states to count three-fifths of each black person toward congressional representation. This latter clause has been viewed as symbolically and racially demeaning toward the black race, yet it was the two clauses that most dehumanized African Americans in the early republic and antebellum United States. For while the latter clause gave slave states more congressional representation, those states would have loved for each black person to count one-for-one to further strengthen their collective

\footnotetext{
${ }^{5}$ William W.Freehling, "The Founding Fathers and Slavery," The American Historical Review 77, no. 1 (1972), 81-93.

${ }^{6}$ Paul Finkelman, Slavery and the Founders: Race and Liberty in the Age of Jefferson (M.E. Sharpe, New York, 1996), 3.
} 
congressional strength. ${ }^{7}$ The two latter clauses, by contrast, directly affected the everyday lives of African Americans because they subjected them to commodification, manhunts and a host of other brutal realities of American slavery. Hopkins and Sharp had long argued that these measures, which had been part of American slavery during the colonial period in advance of their enshrinement into the Constitution, were against the Bible. Their arguments were characterized not only by biblical principles but by emphasizing the humanity of Africans being victimized by fugitive slave laws and the slave trade. For Sharp, the two exceptionable clauses represented the future seeds of destruction to the Union. The Constitutional Convention also exposed the seeds of impending division between the states over the issue of slavery.

The American Revolution dealt a blow to American Slavery through its rhetoric of freedom, as slaves fled to fight for the British, as slaves were granted their freedom in exchange for their armed service, and as northern states began to dismantle it through gradual abolition laws. Yet it has been argued that American slavery actually emerged stronger after the Revolution in consequence of the Constitution. ${ }^{8}$ Slave states wielded much power throughout the constitutional ratification process because of their wealth and their threat of refusing to ratify a Constitution that did not protect American slavery. The addition of clauses protecting slavery guaranteed that that American slavery could deepen and strengthen in the South while expanding westward. ${ }^{9}$ Embedding those clauses in the Constitution enabled Southern Americans to create and protect a peculiar brand of

\footnotetext{
${ }^{7}$ Farrand, Records of the Federal Convention, vol. 1, 542.

${ }^{8}$ Finkelman, Slavery and the Founders, 3.

${ }^{9}$ Van Cleve, Slaveholders' Union, 179.
} 
slavery. Because their triumph in the Philadelphia Constitution Convention was

conducted in secret, and the decisions were made outside of the public view, transatlantic abolitionists could not weigh into the debate or encourage public opinion against the inclusion of proslavery clauses in the Constitution. The inclusion of these clauses into the Constitution was not by any means a fait-accompli, and it would be a misnomer to assume that revolutionary rhetoric would completely subsume American slavery. The states were, however, exhibiting nascent clear signs of division over the issue of slavery in the early stages of the nation's development. Southern states flexed their political proslavery muscles even as the war began and as the Thirteen Colonies coalesced around the Declaration of Independence. Thomas Jefferson was forced to delete an anti-slave trade tirade out of his original draft of the Declaration of Independence. James Madison, a Virginian, later observed in 1783 that there was "compromise between the wide opinions and demands of the Southern and other states" and he believed compromise in the Constitution was "material to future harmony and justice among members of the confederacy." ${ }^{10}$ Madison understood early on that there was a divide between the states heading into the Constitutional Convention and remarked that the "difference of interests did not lie where it had hitherto been discussed, between the great \& small States; but between the Southern and Eastern." ${ }^{11}$ Politicians in Northern states therefore knew that concessions would have to be made with the South to maintain the Union. ${ }^{12}$

\footnotetext{
${ }^{10}$ James Madison to Edmund Randolph, Philadelphia, April 8, 1783, in James Madison and Gaillard Hunt, The writings of James Madison, comprising his public papers and his private correspondence, including numerous letters and documents now for the first time printed (New York: G.P. Putnam's Sons, 1900), 523.

${ }^{11}$ Farrand, Records of the Federal Convention, vol. 1, 601.

${ }^{12}$ Ibid, 562.
} 
Reflecting biblical arguments made by transatlantic abolitionists, delegates on both sides of the Mason-Dixon Line raised questions about the morality of American slavery during the Constitutional deliberations over the " $3 / 5^{\text {ths" }}$ Clause. Gouverneur Morris, a delegate from Pennsylvania (a state dominated by Quakers), noted while debating the issue of using slaves for representation called the slave trade a "defiance of the most sacred laws of humanity tears away his fellow creatures from their dearest connections \& damns them to the most cruel bondage." ${ }^{13}$ Morris contended that this was viewed by his constituents with "a laudable horror, so nefarious a practice." ${ }^{14}$ Luther Martin, of Maryland, a slave state, argued that counting slaves toward representation would encourage the slave trade which "was inconsistent with the principles of the revolution and dishonorable to the American character to have such a feature in the Constitution." ${ }^{15}$ Reflecting the writings of transatlantic abolitionists like Sharp and Hopkins, George Mason of Virginia, warned of divine retribution for "this infernal traffic" and cautioning, "They bring the judgment of heaven on a Country. As nations cannot be rewarded or punished in the next world, they must be in this. By an inevitable chain of causes \& effects providence punishes national sins, by national calamities." ${ }^{16}$ Madison also lamented that the young republic's character was marred by slavery and noted that, "where slavery exists, the republican theory becomes still more fallacious."17

\footnotetext{
${ }^{13}$ Ibid, vol. 2, 222.

${ }^{14}$ Ibid, vol. 2, 222.

${ }^{15}$ Farrand, Records of the Federal Convention, vol. 2, 364.

${ }^{16} \mathrm{Ibid}, 370$.

${ }^{17}$ Madison, Notes on the Constitution, 19.
} 
He was also concerned that a twenty year extension to the slave trade would "produce mischief" and that "so long a term will be more dishonorable to the American character than to say nothing about the Constitution." 18 The idea of putting any notion of humans as property anywhere in the Constitution was noxious to some Southern as well as Northern delegates. Madison and others felt it was morally wrong to put the word "slave" or "slavery" anywhere in the Constitution. ${ }^{19}$

Many delegates, in contrast to Madison and Mason, denied that morality or religion had anything to do with the issues at hand. John Rutledge of South Carolina, a slave state that opposed any notions of excluding slave friendly clauses in the Constitution, argued that "Religion \& humanity [have] nothing to do with this questionInterest alone is the governing principle with Nations. ${ }^{20}$ For him keeping the Union intact, with southern states as "parties to the Union" was "The true question at present." 21 In fact, he went on, "If the Northern States consult their interest, they will not oppose the increase of Slaves which will increase the commodities of which they will become the carriers." ${ }^{.22}$ Rutledge later reiterated his point saying that "If the Convention thinks that N.C.; S.C. and Georgia will ever agree to the plan, unless their right to import slaves be untouched, the expectation is vain. ${ }^{, 23}$ Other delegates from Southern states bluntly

\footnotetext{
${ }^{18}$ Ibid, 50.

${ }^{19}$ Ibid, 52,56.

${ }^{20}$ Farrand, Records of the Federal Convention, 364.

${ }^{21}$ Ibid, 364.

${ }^{22}$ Ibid, 354.

${ }^{23}$ Ibid, 373.
} 
informed their Northern counterparts they were voting according to their interests.

Furthermore, they would never tolerate a Constitution without protections to slavery nor join the Union where their property in humans was not safeguarded. According to Madison's notes, General Charles Coteworth Pinkney of South Carolina "declared it to be his firm opinion that if himself \& all his colleagues were to sign the Constitution \& use their personal influence, it would be of no avail towards obtaining the assent of their Constituents." ${ }^{24}$ He maintained that "South Carolina \& Georgia cannot do without slaves" and that "it would be unequal to require S.C. \& Georgia to confederate on such unequal terms. ${ }^{25}$ Abraham Baldwin of Georgia confirmed Pinkney's assertion and said "Georgia was decided on this point." ${ }^{, 6}$ Hugh Williamson, of North Carolina who joined the intransigent Southern block, agreed and maintained that the Southern states simply would not join the Union if the slave trade clause was rejected. ${ }^{27}$

Southern delegates wore down the Northern delegates' opposition and forced their capitulation. Roger Sherman of Connecticut conceded that it was better to allow the Southern states keep the slave trade "if they made that a sina qua non." ${ }^{28}$ Understanding how their decision would be viewed on a moral basis, Edmund Randolph of Virginia summarized the moral dilemma facing the delegates. On the one hand, their agreement would outrage their Quaker and Methodist constituents. On the other hand, if they

\footnotetext{
${ }^{24}$ Ibid, 371.

${ }^{25}$ Ibid.

${ }^{26} \mathrm{Ibid}, 373$.

${ }^{27}$ Ibid.

${ }^{28}$ Ibid, 374.
} 
opposed the compromise on slavery, they risked losing two whole states-South Carolina and Georgia. ${ }^{29}$ Madison quoted Randolph as saying, "Let us then try the chance of commitment [approve the slave trade]. ${ }^{{ }^{30}}$ With the South prevailing on the larger issues of whether the slave trade will continue, even if for twenty years and later the approval of a fugitive slave clause, all the North had to contend over was whether the words "slave" or "slavery" or even "servitude" would appear on the Constitution thus marring it. The South, satisfied that its institution was safely intact, easily ceded the point; and the motion made by Edmund Randolph to exclude the word "slave" or "servitude" from the Constitution of Virginia, passed unanimously. ${ }^{31}$

Despite the Constitutional Delegation's insertion of slave friendly clauses in the Constitution; transatlantic abolitionists had long established their biblical arguments against the slave trade and the fugitive slave measures. Hopkins and Sharp argued that the American Revolution was divine retribution for slavery and they referenced the slave trade and fugitive slave laws as odious features of the oppressive system, and they carefully outlined their biblical arguments against specific aspects of the slave trade and fugitive slave laws. They argued that these particular aspects of American slavery were in direct violation of scripture. Though Sharp was not present in the Constitutional deliberations, his moral influence loomed over the proceedings. Ironically, it was a Sharp's legal antislavery brainchild that provoked one of the constitutional slave friendly clauses. While revolutionary rhetoric and the war itself challenged American slavery,

\footnotetext{
${ }^{29}$ Ibid.

${ }^{30}$ Ibid.

${ }^{31}$ Ibid, 607.
} 
another key pre-war development that affected the institution was the Somerset decision of 1772 across the Atlantic in England. In the 1772 case Somerset v. Stewart Chief Justice Lord Mansfield found for the plaintiff, James Somerset, who was a fugitive slave seeking refuge in England with Sharp's help. After he was captured by his owner Charles Stewart he was chained and placed in custody in preparation for future sale. Mansfield found that Somerset, because he had landed in England, was now under England's laws and the King's subject. As such, he was no longer deemed property but as a person whose legal status was as a slave. Since there was no positive law making slavery legal in England, Somerset's legal status must be declared free. Mansfield's ruling, therefore, set a precedent that a person's legal status (slave or free) was determined by where that person was and what the positive law of that place or jurisdiction was. ${ }^{32}$ Mansfield's ruling had far reaching effects both in England and in the American colonies. First, it reversed a longstanding English (and later American) precedent in which slaves were considered property no matter where they traveled. Second, it encouraged slaves to attempt escape to jurisdictions where they might be legally declared free. Third, it did not allow for slaves to be forcibly taken from the place where they might have sought refuge to be sold or forced back into bondage. Fourth, it forced American slaveholders to scramble to ensure that there were protections in place for their slave property moving forward as they sought to establish the young American republic. The key protection against the Somerset ruling they sought was in the form of fugitive slave laws. ${ }^{33}$

\footnotetext{
${ }^{32}$ Van Cleve, Slaveholders' Union, 31-32.

${ }^{33}$ Ibid, 32-36.
} 
Through the Articles of Confederation, the Northwest Ordinance and the Constitution, the slave states worked hard to ensure that a fugitive slave clause was embedded in the founding documents of the young U.S. A key proponent of this movement was Richard Henry Lee of Virginia, who chaired the slave state delegate majority committees that recommended the language that went in the Articles of Confederation and the Constitution for the Fugitive Slave clause. The clause was specifically designed to protect "slave property against the operation of the principles of the Somerset decision and the post-1776 legal authority of states to ban slavery." 34 That the slave state powers like Lee had to diligently work to install fugitive slave laws in the Articles of Confederation, the Northwest Ordinance, and the Constitution to counteract the Somerset decision is evidence that Sharp had an impact on American slavery, even if it was to put it on the defensive. Sharp worked not only to help James Somerset secure legal defense, but also publicized the decision by sending dispatches to America where his abolitionist cohorts such as Anthony Benezet and Benjamin Rush disseminated the findings to their antislavery networks. ${ }^{35}$ The news spread fast and soon slaves were suing for freedom and their attorneys were using the Somerset decision as precedent in their arguments for slave manumission. Meanwhile slave owners were forced to consider ways that they might protect their "property" by determining slaves' flight to places where they could become free. ${ }^{36}$

\footnotetext{
${ }^{34}$ Ibid, 168-169; George Van Cleve argues that "slave states deemed the ordinances fugitive slave proviso an essential means of controlling slavery within slave states by preventing slave flight to a new "territorial magnet."

${ }^{35} \mathrm{Ibid}, 35$.

${ }^{36}$ Ibid, $35-36$.
} 
There has been scholarly debate as to whether American slavery was preceded by racism or if the need to maintain and control a permanent labor force necessitated a racial definition for who could be deemed slave property. The former camp is led by Winthrop Jordan while the latter has Edmund Morgan as its dean. What both camps agree on, however, is that racism and slavery were inseparable parts of American slavery from as early as the late $17^{\text {th }}$ century ${ }^{37}$ Virginia set the precedent for slave codes as early as 1662 , when it was established that Africans brought in through the slave trade, and their children, "shall be slaves for their lives" according to the "condition of the mother." 38 The Legislature thereafter established a series of harsh codes that deemed slaves to be "real estate" and "chattel" and under the complete power of their masters. ${ }^{39}$ Slaves had no civil liberties as they were prohibited from meeting. ${ }^{40}$ They had no recourse to provide for themselves as they were prohibited from planting and growing their own crops or keep livestock. They could not own property or build wealth as they could not rent houses or purchase property. ${ }^{41}$ Slaves had no power even over themselves as their masters were given leeway in punishing them. If a slave died in the process of punishment, the master was held harmless. ${ }^{42}$ Slaves could not move from their master's

\footnotetext{
${ }^{37}$ Winthrop D. Jordan, White over Black: American attitudes toward the Negro, 1550-1812 (New York: Norton, 1977), 44; Edmund S. Morgan, American Slavery, American Freedom: The Ordeal of Colonial Virginia (W.W. Norton \& Company, Inc.: New York, 1975), 315.

${ }^{38}$ John C. Hurd, The law of freedom and bondage in the United States (New York: Negro Universities Press, 1968), 228, 232, 233, 299, 303.

${ }^{39}$ Ibid, 240, 242.

${ }^{40}$ Ibid, 300 .

${ }^{41}$ Ibid, 307.

${ }^{42}$ Ibid, 232.
} 
plantation unless with a "ticket" or "certificate" and it was lawful for such a slave to be "corrected by any white person." 43 Upon correction, it was the responsibility of the slave to submit; 44 and if upon correction the slave instead "assaulted" or struck the white person, such a slave could be "lawfully killed." 45 Slaves received thirty lashes at the mere "lifting [of] his hand against a white person;" 46 and slaves who were considered disorderly could legally be dismembered. ${ }^{47}$ If the slave died in the process, provided the death was considered unintentional, it would not be considered murder but perhaps manslaughter after trial. ${ }^{48}$ Africans could not legally defend themselves since their testimony against a white person was inadmissible in a court of law. ${ }^{49}$ They could not bear arms "unless on the frontier and with a license." $" 50$ Trial by jury for slaves was illegal. ${ }^{51}$ Castration was legal if a slave or "Negro" were to "attempt to ravish a white woman." 52 It was unlawful to teach slaves to read. ${ }^{53}$ Slaves could not vote nor could they

\footnotetext{
${ }^{43}$ Ibid, 234, 304.

${ }^{44} \mathrm{Ibid}, 304$.

${ }^{45}$ Ibid.

${ }^{46}$ Ibid, 244.

${ }^{47}$ Ibid, 242.

${ }^{48}$ Ibid.

${ }^{49}$ Ibid.

${ }^{50}$ Ibid.

${ }^{51}$ Ibid, 238, 245.

${ }^{52}$ Ibid.

${ }^{53}$ Ibid.
} 
hold public office. ${ }^{54}$ Many of these codes were still in place in Virginia at the time of the Constitutional Convention of 1787.

Southern colonies sought to safeguard their harsh institution with fugitive slave laws. As early as 1663 , one year after officially defining slaves as hereditary property according to "the condition of the mother," Virginia instituted a law that fugitives "be pursued. ${ }^{.55}$ Other Southern colonies also established laws that provided for the apprehension and detention of fugitive slaves from other slave colonies and provided for rewards for their capture. ${ }^{56}$ The punishment for captured fugitive slaves could be as severe as death. ${ }^{57}$ The slave codes, however, could not safeguard the human property of the Southern states in a rapidly expending union. The slave states understood that fugitive slave laws provided the legal framework to undergird and maintain their peculiar institution. Without fugitive slave laws in place, American slavery would have probably collapsed and bled out through a heavy hemorrhaging of runaway slaves. The American Revolution had already spurred many to run away. With Northern states steadily moving toward gradual abolition laws, the vast unsettled territory in North America with plenty of inviting space for fugitives to roam and the burgeoning popularity of the Somerset decision, Southern states had to pass fugitive laws that could safeguard their property in humans. Richard Henry Lee and his cohort of southern lawyers were therefore predictably focused on creating a fugitive slave law leading up to and in the

\footnotetext{
${ }^{54}$ Ibid.

${ }^{55} \mathrm{Ibid}, 232$.

${ }^{56} \mathrm{Ibid}, 244,307$.

${ }^{57}$ Ibid, 300.
} 
Constitutional Convention to protect their slave institution. Sharp likewise placed the issue of runaway slaves and fugitive slave laws in the crosshairs of his biblical argument.

Sharp had a deep conviction that American slavery was against the Bible, or rather, that the Bible stood against American slavery because it depended on fugitive slave laws for its survival. He argued that the hunting of slaves, was specifically prohibited by scripture. The cornerstone of Sharp's biblical argument against the fugitive slave laws can be found in Deuteronomy 23:15 which reads:

"Thou shalt not deliver unto his Master the Servant which is escaped from his Master unto thee: he shall dwell with thee (even) among you, in that place which he shall choose, in one of thy gates where it liketh him best: thou shalt not oppress him." $" 58$

Sharp used this scripture to make the point that the slave had the right, if he deemed it in his best interests, to "escape" and "dwell" anywhere "he shall choose" and where "he liketh him best." Furthermore, those who heeded this scripture were commanded "Thou shalt not deliver [the slave or servant] unto his Master." This scripture then would appear to be a cornerstone part of Sharp's biblical critique of British-American slavery and a driving force behind his work on Somerset. He clearly persuaded Lord Mansfield, who decreed that Somerset was considered free because he had landed in England and could not be compelled to go with his master back into bondage. Indeed, to compel or turn over a runaway slave to go back to his master was considered an act to "oppress him." To be sure, those who heeded this scripture, Sharp argued, were commanded: "Thou shalt not oppress him." It would appear then that to turn or compel a slave to return to his master or turn him over to his master would be considered oppression. Sharp therefore vehemently protested upon learning that the Fugitive Slave Clause had been enacted into

${ }^{58}$ Deuteronomy 23:15 quoted in Sharp's Law of Retribution. 
the U.S. Constitution. In his mind, the United States of America, a nation ostensibly established as a republic of freedom was in fact enacting a Constitution that officially bolstered inhuman bondage.

Sharp, therefore, condemned the brutality of manhunts to recover fugitive slaves. Fugitive slaves ran at the risk of brutal beatings once taken into custody by their masters. Most often it was a bounty hunter who did the hunting on behalf of the master seeking to retrieve his slave. Slave autobiographies describe the harrowing feeling of runaway slaves being pursued under the threat of being caught and severely punished.$^{59}$ In his condemnation, Sharp referenced Amos 1:11 and applied it to American slavery:

"Thus saith the Lord; for three Transgressions of Edom, and for four, I will not turn away (the punishment) thereof; because he did pursue his Brother with the Sword, and did CAST OFF ALL PITY towards their poor RUNAWAY SLAVES! for I have seen rewards publicly offered for the Heads of those poor oppressed People." 60

Here, Sharp referenced the pitiless process by which humans were hunted and applied the ire of the prophet Amos over slavery in antiquity to African slavery in America. Sharp coupled this passage in Amos with a notice from the Carolina Gazette by a Robert Wells dated 30 Dec. 1774 titled, "A Hundred Pounds Reward” for a runaway slave. Sharp was appalled by the extent to which the colonists vigorously pursued their "oppressed" runaway slaves. For Sharp, scripture applied because the African slaves were his brothers and sisters worthy of freedom. This stood in stark contrast to proslavery apologists who while showing no regard for these social conditions among the African slaves, used the

\footnotetext{
${ }^{59}$ Henry Louis Gates, ed. The Classic slave narratives (New York, N.Y., U.S.A.: Penguin, 1987), 421-423, 546-553.

${ }^{60}$ Sharp, Law of Retribution, 237-238.
} 
Bible to argue that Africans were condemned to the lowest forms of slavery. ${ }^{61}$ For Sharp, fugitive slaves were not to be handed over to their masters nor were they to be pitilessly "pursued with the sword" as it were. Both hunting and turning over fugitive slaves as featured in American slavery were against scripture according Sharp. The Constitutional Fugitive Slave Clause was therefore, in Sharp's eyes, not only a violation of a biblical command but also a license for masters to pitilessly pursue their fugitive slaves all over the Union.

Sharp engaged in a debate with proslavery apologists over the issue of fugitive slaves. The point of contention was a hotly debated scripture used by proslavery apologists to argue for the return of slaves to their masters. ${ }^{62}$ He took on Thomas Thompson, a fellow Anglican who had traveled throughout the West Indies, New Jersey and back to England, Sharp argued that the Bible did not allow for the return of a fugitive slave to his master. ${ }^{63}$ Thompson, for his part, centered on whether, or not, the legal slave trade was forbidden by God's law, and thus a national sin. He argued that it was not. Citing Leviticus 25:39-55-which apparently allowed Israelites to buy and retain foreigners as slaves for life even willing them to their children if they wishedThompson maintained that the Bible did not forbid the buying and selling of slaves. The

${ }^{61}$ Drew Gilpin Faust, The Ideology of slavery: proslavery thought in the antebellum South, 1830-1860 (Baton Rouge: Louisiana State University Press, 1981), 14-15; William Sumner Jenkins, Pro-slavery thought in the Old South (Gloucester, Mass: P. Smith, 1960), 201; Mark A. Noll, The Civil War as a theological crisis (Chapel Hill: University of North Carolina Press, 2006), 34.

${ }^{62}$ Thomas Thompson, The African Trade for Negro Slaves, Shewn to Be Consistent with Principles of Humanity, and with the Laws of Revealed Religion (Canterbury, n.d. [1772 or possibly 1773]), pp. 8-12, 31; Lev. 25:39-55 discussed by Davis in Problem of Slavery, 531-532.

${ }^{63}$ Granville Sharp, An essay on Slavery, Proving From Scripture its Inconsistency with Humanity and Religion (Burlington, West Jersey, 1773; reprinted London, 1776), pp. 19-22; Sharp, The Just Limitation of Slavery in the Laws of God, Compared with the Unbounded Claims of the African Traders and British American Slaveholders (London, 1776), 10-11, 14, 26. 
debate between Sharp and Thompson also involved the story of Onesimus as recorded in the New Testament book of Philemon. Onesimus, a slave of Philemon, a Christian and pupil of the Apostle Paul, had run away to Paul. Paul, a former Pharisee and thoroughly educated in the Law of Moses thus aware of the edict in Deuteronomy 23, returned Onesimus to Philemon, apparently in contradiction to the scriptures. If slavery was wrong, Thompson argued, why did Paul return Onesimus to Philemon? Thompson's tract was provocative and sent ripples across the Atlantic where the Philadelphian Quaker antislavery advocate, Anthony Benezet, was infuriated. Sharp, Thompson's his fellow Anglican congregant, took leave of absence from the Office of Ordnance to write 4 tracts, two of which directly addressed Thompson and the issues he outlined. Sharp took Thompson to task over the issue of Onesimus and argued that Paul's instructions to Philemon were not for Philemon to receive Onesimus to re-enslave him. Instead Philemon was to accept Onesimus "not as a slave, but better than a slave, as a dear brother." ${ }^{94}$ Sharp therefore argued that if a runaway slave were to be returned to his master, according to Paul's instructions to Philemon, he must be returned in a humanely fashion, not as a criminal. This was in contrast to the racist nature of American slavery which never approached any pretense of brotherhood or familial ties. Captured runaway slaves were to be hunted and severely punished upon apprehension. Southern delegates, far from suggesting that fugitive slaves were their brothers, argued during the Constitutional Convention that runaways should be delivered up as criminals. That motion, which was rejected out of hand, displays that fugitive slaves would not be

\footnotetext{
${ }^{64}$ Sharp, An essay on Slavery, 24-25; Apostle Paul, Philemon 16-17, The Holy Bible, New International Version (Holman Bible Publishers: Nashville, 1986).
} 
received in the spirit that the Apostle Paul urged Philemon to receive Onesimus, but would have allowed Southern states, by law, to treat runaway slaves as property and even criminals.

The regard for Africans as brothers worthy of brotherly love is a hallmark of the biblical arguments deployed by American abolitionists like Hopkins against the slave trade. Their scriptural arguments quoted scriptures and demonstrated how the slave trade dehumanized and destroyed the lives of its victims. This abolitionist argument stood in contrast to the deliberations during the Constitutional Convention which largely overlooked how a continuance of the slave trade would impact Africans. Meanwhile, the suffering and hardship of Africans victimized by the slave trade were a hallmark of the writings of transatlantic abolitionists. Hopkins described the sufferings of Africans due to the slave trade and cited scriptures that showed God's displeasure with the trafficking of humans. Hopkins described how the slave trade created widows, orphans and strangers out of the Africans and thus made them vulnerable populations that were expressly afforded divine protection. Hopkins argued that the slave trade was an atrocity, and described the process by which captured Africans were reduced to the status of "beasts" as they were ripped away from their homeland regardless of "their acquaintances, relations, family members and friends." ${ }^{\circ 5}$ Africans, Hopkins asserted, were transformed into widows and orphans, as men and women lost their spouses, and children were torn away from their parents, as if those loved ones were now dead to them. Thus, they instantly became widows and orphans.

\footnotetext{
${ }^{65}$ Hopkins, Dialogue, 10.
} 
After their separation from loved ones, Africans were then commodified as they were in the slave market. Hopkins decried that Africans were "put in irons" to be "sold at the market places after being examined by a surgeon" representing the slave traders. ${ }^{66}$ Purchased Africans were branded and squeezed into small quarters of a ship to be transported across the Atlantic via the Middle Passage. Hopkins angrily noted that only seven out of ten enslaved Africans reached the final destination. By his count, roughly 30,000 Africans a year died on the way and perhaps as many as 3 million in the $18^{\text {th }}$ century through the transatlantic slave trade.$^{67}$ After being torn from their homeland, sold and brought to a new world, they became impoverished strangers in a new land. Those who survived the middle passage were sold to their eventual owners regardless of familial ties. Their new owners, Hopkins noted in disgust, "assigned their work" giving no consideration to disability as the "infirm and feeble, the females and even those who were pregnant" had to work in the fields with everyone else or "face the lash." The food the slaves ate was "was coarse and scant" and they often went without food ${ }^{68}$ Slave masters were harsh and slaves dared not complain lest they "expose them [selves] to severe punishment or death." The masters were quick to "punish the least intimation of [freedom] in the severest manner" and took any hint of desire for freedom as an "affront and insult" to their authority. Africans often died due to the harsh working conditions. Hopkins wrote that "their labour [sic] is so hard, and their diet so scant" that they

\footnotetext{
${ }^{66}$ Ibid.

${ }^{67}$ Ibid.

${ }^{68}$ Ibid.
} 
"constantly decrease in population" forcing the planters to "purchase five to every hundred he has on his plantation to keep his numbers from diminishing."

Regardless of the hardships the slave trade placed on Africans, the slave states understood that the slave trade was vital for the replenishment of their institution. It should be noted that compared to slavery in the West Indies the demographic evidence available shows that the numbers of slaves in North America did not diminish. ${ }^{70}$ The southern slave states also wanted to spread slavery into the territories which would require a large influx of slaves that the international slave trade, expanded by twenty years, fueled. By prolonging the international slave trade by twenty years the slave states were able to infuse roughly over 170,000 new slaves into their slave economy between the years of 1791 and 1810. Five new slave states were added on the backs of slaves between 1791 and 1820 which gave the slave states 10 new Senators and at least 10 new congressional seats in the House of Representatives. ${ }^{71}$

But, as Hopkins would argue, a slave labor force acquired through the slave trade and protected by a Constitutional clause was, in fact, made up of stolen property. Borrowing the language of natural rights and combining it with biblical mandate against stealing, Hopkins maintained that the Africans had been enslaved despite "having never forfeited their liberty, or given any one a right to enslave and sell them..." Thus for Hopkins slave traders were "piratical tyrants," who not only stole the Africans away from

\footnotetext{
${ }^{69}$ Ibid, 11.

${ }^{70}$ Van Cleve, Slaveholders' Union, 147-148; Philip D. Curtin, The Atlantic Slave Trade: A Census (Madison: University of Wisconsin Press, 1969), 88-89 cited in Albert J. Raboteau, Slave Religion: The "Invisible Institution" in the Antebellum South (Oxford: Oxford University Press, 2004), 89-92.

${ }^{71}$ Van Cleve, Slaveholders Union, 150.
} 
their land and families, thus reducing them to widowhood and orphans, but they also violated and usurped their rights. By stealing them from their homeland, Hopkins argued, "piratical" slave traders were stealing the most precious God-given right Africans possessed at birth - liberty. ${ }^{72}$ Hopkins raised questions about the very industry that many Americans deemed essential to expand American slavery west. Hopkins wrote that "holding these blacks in a state of slavery, is a practical justification of the slave-trade, and so brings the guilt of that on the head of him, who so far partakes in this iniquity..."73 For Hopkins, to hold slaves was tantamount to dealing in stolen goods. He believed that "the partaker is as bad as the thief." 74 Hopkins scoffed at slave owners who demanded compensation for the losses incurred from the manumission of slaves or the loss of human property was basing his claim on a faulty premise. Hopkins demanded instead that the slaves should be compensated for the loss of their freedom and ability to work to enrich themselves and their families stating, "we have made them our slave without the least right; and ought to retract it, and repair the injury done to them, so far as is in our power, by setting them free, and compensating them otherwise, so far as we are able." ${ }^{275}$ Hopkins simply asked: Should a slave owner be compensated for returning property he acquired from someone who stole it? ${ }^{76}$ Hopkins, in essence, saw the Constitutional Convention's extension of the slave trade another 20 years as tantamount to extending human thievery for 20 years.

\footnotetext{
${ }^{72}$ Hopkins, Dialogue, 15.

${ }^{73}$ Ibid.

${ }^{74}$ Ibid.

${ }^{75}$ Ibid, 16.

${ }^{76}$ Ibid, 16-18.
} 
Abolitionists like Hopkins and Sharp also defended the rights of Africans as strangers in a foreign land and used the scriptures to support their point. As has been noted, central to the abolitionists' biblical arguments was their insistence that the people who were being exploited by American slavery were those in vulnerable positions in society regardless of race. As strangers, or foreigners or immigrants in a foreign land, abolitionists maintained that enslaved Africans were vulnerable and thus were afforded the special protection of God. This, as has also been noted, stood in contrast to proslavery apologists who used the Bible to argue that Africans were cursed by God to a life of perpetual bondage. But while proslavery advocates used the story of the Curse of Ham in which Noah cursed his son's progeny for reporting that he saw his father naked in his tent, abolitionists used a host of scriptures that were direct quotes attributed directly to God. The biblical verses often were from the books written by Moses or one of the Prophets who emphasize God's insistence that the widow, the orphan, and the stranger were to be treated well and not oppressed in any way. Abolitionists like Hopkins and Sharp all came back to this point repeatedly to emphasize how God was the prime defender of the widow and orphan and that aliens were included in that group. A key example of this is Sharp's use of a passage in the book of Deuteronomy to argue that God was the defender of these mentioned groups. Sharp wrote:

"Thou shalt neither vex a Stranger, nor oppress him; for ye were Strangers in the Land of Egypt. Ye shall not afflict any Widow or fatherless Child. If thou afflict them in any wise, and they cry at all unto me, I will SURELY hear their cry..."”77

As Africans were extracted from their homes, pushed through the gauntlet of the slave trade and the middle passage, they were reduced in the Americas to being impoverished

\footnotetext{
77 Sharp, The Law of Retribution, 15-16.
} 
and vulnerable widows and widowers, orphans and strangers in a land not their own. Thus, for abolitionists they became a population that God had specifically warned most be held harmless. According to scripture, God would "surely hear their cry..."

Abolitionists vehemently warned that God would not only hear their cry, but he would also respond through divine retribution. This passage then is central to the theological underpinning of Sharp's argument against British-American slavery.

In a nation where enslaved "strangers" were dehumanized by the newly ratified Constitution, Sharp emphasized that the Bible condemned the oppression of strangers. He quoted the biblical text with his commentary, "'thou shalt not oppress a Stranger: for ye KNOW THE HEART (properly THE SOUL) OF A STRANGER, seeing ye were Strangers in the Land of Egypt.' Exod. xxiii. 9." 78 This passage takes on new meaning when one considers that European-Americans were originally strangers in the Americas. Sharp posited they should "know the heart of a stranger" for they themselves were strangers in the Americas, just as the Israelites had been in Egypt. As strangers in America, Africans, therefore, should not be oppressed. "'Thus saith the Lord,' (i.e. Jehovah) 'God of Israel:'” Sharp proclaimed, "'I brought you up from Egypt, and brought you forth out of the House of Bondage;' (more literally 'from the House of Slaves') 'and I delivered you out of the hand of Egyptians, and out of the hand of all that oppressed you,' \&c. Judges vi. 8." ${ }^{, 79}$ Sharp believed the Israelites were reminded of their oppressions in Egypt to spur them to "sympathetic concern for the Sufferings of the

\footnotetext{
${ }^{78}$ Exodus 22:21-23 (KJV) quoted by Sharp in Law of Retribution, 15.

${ }^{79}$ Ibid, 13-14.
} 
Oppressed, and more particularly of Oppressed Strangers." ${ }^{80}$ By virtue of extracting Africans from their homeland and bringing them in a forced migration to the Americas, British-Americans slave traders were creating and "vexing" a population of "strangers" that God had warned should not be "vexed" or oppressed.

After the Constitution became official Sharp and Hopkins remonstrated against the decisions that clearly went against what they had argued years before. Sharp's response to Franklin has been noted. And for Hopkins the Constitutional compromises represented disrespect for providence that helped the United States in its struggle against Great Britain during the Revolution. He noted that the first Congress had resolved in 1774 to no longer import slaves beginning in 1775 . Hopkins had been buoyed by this development as it appeared to be the will of the people and God's kind providence secured. Years later he reflected on this development:

All the people appeared to acquiesce in this resolution, as reasonable, important, and necessary, in order to act a consistent part while contending for their own liberties, and to have any ground of hope in the protection and smiles of a righteous God, and success in the struggle into which we were entering. With this resolution we entered the combat, and God appeared to be on our side, and wrought wonders in our favor, disappointed those who rose up against us, and established us a free and independent nation. ${ }^{81}$

Hopkins wondered aloud why the United States ratified measures that violated of God's law. He feared that the nation might undergo divine retribution because of the Constitutional compromises over slavery:

${ }^{80}$ Ibid, 15.

${ }^{81}$ Samuel Hopkins, "A Discourse Upon the Slave Trade and the Slavery of the Africans Delivered before The Providence Society for Abolishing the Slave Trade, \&c, At Their Annual Meeting, May 17, 1793," Timely Articles on Slavery (1854; Mnemosyne Publishing Inc., 1969), 606 cited in Rodriguez, "Spirit of $76, " 20$. 
When all this is taken into view by the truly pious, who fear God and believe his word, is it to be wondered at that their flesh trembleth for fear of the righteous judgments of God? Are they to be condemned as superstitious enthusiasts? Have we not all reason to fear that the vengeance of Heaven will fall upon us, as a people, in ways perhaps which are not now thought of, unless we repent and reform? ${ }^{82}$

Hopkins, who died in 1803, would never see the national repentance and reform for which he prayed. But in his lifetime he believed there would be a divine reckoning for slavery. Writing in 1787 to Moses Brown, a Quaker abolitionist, he protested the slave friendly Constitution by calling it an "Achan" and predicting that the "Supreme Ruler of the universe" would "vindicate [the] oppressed and break [the] arm of [the] oppressor in his own way and time; and cause [the] wrath of man to praise." ${ }^{\prime 83}$ Hopkins' "Achan" reference referred to an instance in Jewish history when the Israelites were routed by a smaller nation because, one among them, Achan, had stolen items that were supposed to be set aside for God. In view of Achan's actions, God in turn refused to help the Jewish army in their battle against Ai thus causing their defeat, according to the Achan account related in Joshua 7. In Hopkins's mind, and as previously mentioned, the Africans, who as God's creatures belonged to him, also had been stolen from their homeland. Therefore oppressive Americans could expect that God would in his wrath "vindicate" the stolen Africans and "break the arm of the oppressor," namely the Americans, in "his own time." Like Sharp, Hopkins believed that the United States had

\footnotetext{
${ }^{82}$ Hopkins, Discourse, 606.

${ }^{83}$ The Achan reference is from Joshua 7; quote cited by James H. Smylie in his "Protestant Clergymen and American Destiny: I. Promise and Judgment, 1781-1800," The Harvard Theological Review 56, (July 1963): 217- quote on p. 227-28; from Samuel Hopkins to Moses Brown, October 22, 1787, Moses Brown Papers, Rhode Island Historical Society.
} 
opened itself for future divine retribution by codifying measures in the Constitution that supported an unjust system.

As Sharp and Hopkins maintained, constitutional compromises over slavery had dire consequences for Africans as Africans became grist for the economic development of the burgeoning American empire. The ratification of the U.S. Constitution in 1789 left the southern states with a mandate to strengthen the slave institution and its spread into the western territories. The Constitution allowed the states free reign to do as they pleased within their own borders without interference from the federal government. ${ }^{84}$ The southern states had a twenty year window to add thousands of stolen African slaves fresh from the international slave trade into their developing cotton enterprise. From 1787 to 1807 Americans hastened to import up to 100,000 Africans to meet the constitutional deadline. ${ }^{85}$ That number amounted to roughly $25 \%$ of the total of 400,000 African slaves that were imported in over a century. ${ }^{86}$ The closing of the international slave trade, however, did not close the slave trade as it was still perfectly legal domestically. The Constitution had only promised to close the international slave trade in twenty years, but said nothing of regulating a domestic slave trade. States like Virginia and Maryland simply "diffused" their slaves by selling them to entrepreneurs who resold them further

\footnotetext{
${ }^{84}$ George Van Cleve has argued, “The fundamental result of applying federalism to American slavery was to leave the major slave states, which collectively had contained 87 percent of the 1770 slave population free to maintain and expand slavery for a generation after the Revolution," Founding a Slaveholders, Union, 122.

${ }^{85}$ Edward E. Baptist, The Half has Never been told: Slavery and the Making of American Capitalism, (Basic Books: New York, 2014), 40.

${ }^{86}$ Philip D. Curtain, The Atlantic Slave Trade: A Census (University of Wisconsin Press: Madison, 1969), 88.
} 
south and west. ${ }^{87}$ As a result of the domestic slave trade, almost a million African Americans were torn from their families and forced to migrate from the Upper South to the Lower South and west over a 70 year period between 1790 and 1860 . Americans, therefore, doubled down on the slave trade. ${ }^{88}$

Despite the biblical arguments of Samuel Hopkins and Granville Sharp, the Three-Fifths Compromise and slave trade (both international and domestic) allowed the south to maintain political strength. In Congress a smaller population was able to effectively play defense against any legal intrusions to their peculiar institution. In 1793 the southern states managed to pass, without much opposition, a Fugitive Slave Law which put more teeth into the already existing Fugitive Slave Clause embedded in the Constitution to trap further enslaved Africans. ${ }^{89}$ Because the Electoral College mirrored the House of Representatives, southern states were able to see strength at the top of the Executive branch. Over the next 70 years, four of the first five presidents were slaveholding presidents and eight of the next twelve held property in humans. One slaveholding president, Thomas Jefferson, engineered the Louisiana Purchase which made millions of acres available for the spread of slavery. The South's political power allowed slavery to grow as a part of the nation's expansion west.

\footnotetext{
${ }^{87}$ On the "diffusion" of slaves through the domestic slave trade see Baptist, The Half, 30, 34-37, 48 and Van Atta, Wolf by the Ears, 3, 35-38.

${ }^{88}$ Baptist, The Half has Never been told, 2-3.

${ }^{89}$ Finkelman, Slavery and the Founders, 81, 98-99.
} 


\section{CHAPTER III}

\section{American Slavery, the Bible and Westward Expansion}

Thomas Branagan, a former slave trader and planter, could not sleep. His conscience tortured him. Horrible scenes of African victims flashed through his mind. $\mathrm{He}$ remembered the trusting and unsuspecting Africans once lured into the chains slavery. Branagan lamented the children he ripped away from wailing and shrieking mothers to be sold at auctions. He bemoaned the dead Africans who were thrown overboard after dying from disease contracted in the miasmic holds of ships. He could still hear the blood curdling screams of men and women as scalding water splashed against their newly whipped bodies. Branagan was alarmed by the imaginary swell of African voices rising in appealing to God for justice. He believed God heard their voices and he found no solace in the possibility that God heard and would take up their cause against him and other oppressors like him. When he could no longer take the pangs of conscience he decided to quit the slave trading business and join the antislavery crusade. He unloaded his guilty conscience into his antislavery tracts beginning in $1804 .{ }^{1}$ Branagan's pained polemics coincided with South Carolina's reengagement of the international slave trade and as Congress geared up to close the 20 year constitutional window to the African slave

\footnotetext{
${ }^{1}$ Thomas. Branagan, Serious remonstrances, addressed to the citizens of the northern states, and their representatives : being an appeal to their natural feelings \& common sense : consisting of speculations and animadversions, on the recent revival of the slave trade, in the American republic: with an investigation relative to the consequent evils resulting to the citizens of the northern states from that event Interspersed with a simplified plan for colonizing the free negroes of the northern, in conjunction with those who have or may emigrate from the southern states, in a distant part of the national territory : considered as the only possible means of avoiding the deleterious evils attendant on slavery in a republic, (Philadelphia, 1805), Slavery and Anti-Slavery, Gale, Florida International University, (accessed July 5, 2016); Thomas Branagan, The penitential tyrant, or, Slave trader reformed: a pathetic poem, in four cantos. $2 \mathrm{~d}$ ed., enl. ... (New-York, 1807) Slavery and Anti-Slavery, Gale, Florida International University, (accessed July 5 , 2016); Thomas Branagan, A preliminary essay, on the oppression of the exiled sons of Africa: consisting of animadversions on the impolicy and barbarity of the deleterious commerce and subsequent slavery of the human subspecies ... (Philadelphia, 1804) Slavery and Anti-Slavery, Gale, Florida International University (accessed July 5, 2016).
} 
trade. Anti-slavery activists like Branagan, David Rice and David Barrow were among those who made biblical arguments to warn Americans against the spread of slavery into the western territories after the ratification of the Constitution.

From the ratification of the Constitution to 1819 , when the expansion of slavery westward encountered its first major obstacle during the Missouri Crisis, the south pulsated westward by adding slave states. First Kentucky in 1792, then Tennessee in 1796, followed by Louisiana in 1812, Mississippi in 1718 and Alabama in 1819 southern states added to their geo-political strength as each state gained two more Senators in the U.S. Senate. American slavery was not, however, without opposition. Northern states had already begun to gradually abolish the institution before the Constitutional Convention. Abolitionists societies began to emerge just prior to the Revolutionary War in northern states like Massachusetts (1773), Pennsylvania (1775), Rhode Island (1785), New York (1785) and Delaware (1788) who all had viable abolitionist societies (though Delaware did not abolish slavery before the 13th Amendment). The abolitionists' societies saw their states pass gradual abolition bills. First Vermont (1777) then Pennsylvania (1780) then Massachusetts (1781) through its state constitution and litigation in the Quok Walker case, Connecticut and Rhode Island followed in 1784, finally New York and New Jersey in 1799 and 1804 respectively. ${ }^{2}$ The correspondence between transatlantic anti-slavery activists like Benezet and Sharp led to the formation of "Society for Effecting the Abolition of the Slave Trade" chaired by Sharp in Great Britain in 1787, the same year of the U.S. Constitution Convention.

\footnotetext{
${ }^{2}$ Christopher Cameron, To Plead our Own Cause: To Plead Our Own Cause: African Americans in Massachusetts and the Making of the Antislavery Movement (Kent State University Press: Kent, Ohio, 2014), 51, 72.
} 
As American slavery faced its gradual demise in the northern states, some like Kentucky Presbyterian Reverend David Rice opposed its spread west of the Appalachian fearing it would harm the young republic. Speaking at the Kentucky convention in 1792, Rice made an impassioned plea against slavery's inclusion into the Kentucky constitution. The Virginia native contended, based on republican values and the Bible, that slavery was bad policy. Rice was not alone in his contention; other Americans often warned of the deleterious effects slavery could have on the budding republic Americans were building. ${ }^{3}$ Rice warned that, "The prosperity of a country depends upon the industry of its inhabitants. Idleness will produce poverty; and when slavery becomes common, industry sinks into disgrace. To labour, is to slave; to work, is to work like a Negroe: and this is disgraceful. Youth are hereby tempted to idleness, and drawn into other vices..."4

As an ordained minister, Rice was not just concerned about the effects slavery would have on the young republic, he believed the institution was unjust. Rice provided a cogent definition of a slave as "a human creature made by law the property of another human creature, and reduced by mere power to an absolute unconditional subjection to his will." His published treatise had as its thematic scripture Isaiah 58:6 which read: "Let the Oppressed go free." Like predecessors who wielded the Bible against slavery, he argued that the institution denied Africans of rights they had never willingly relinquished and forced them to obey laws to which they never consented. ${ }^{5}$ Rice appealed to the sense

\footnotetext{
${ }^{3}$ Davis, Problem of Slavery in the Age of Revolution, 283.

${ }^{4}$ David Rice, Slavery inconsistent with justice and good policy, proved by a speech delivered in the convention, held at Danville, Kentucky by the Rev. David Rice, London, 1793, 11, Slavery and AntiSlavery, Gale, Florida International University, (accessed June 29, 2016).

${ }^{5}$ Rice, Slavery inconsistent with justice and good policy, 8.
} 
of American humanity as he probed with thought provoking questions about the fairness of slavery. The reality of American slavery as Rice saw it was that slaves lived in a state of war and siege under the power of the master. "The master," Rice cried, "is the enemy of the slave: he has made open war against him, and is daily carrying it on in unremitted efforts." Rice questioned the premise that slaves were bound to serve masters under such circumstances. "Can any one [sic] then imagine," Rice questioned, "that the slave is indebted to his master, and bound to serve him? Whence can the obligation arise? What is it founded upon? What is my duty to an enemy, that is carrying on war against me?" Rice allowed that masters under American law were allowed to exercise such warfare against their slaves, but he questioned the justice of such laws. "The master may," Rice challenged, "and often does, inflict upon him all the severity of punishment the human body is capable of bearing; and the law supports him in it. If he does not spare his life and his limbs, he dare not complain: none can hear and relieve him; he has no redress under heaven."

Rice, like other antislavery writers, believed that African slaves inherently possessed the same rights as whites. He probed the hearts of his fellow white Americans to question if they had compassion and challenged them to empathize with the plight of slaves. Rice challenged his audience to "consider these things" and ask themselves the justice of a system that forced "a fellow creature, who has never forfeited his freedom, into this wretched situation; and confine him and his posterity in this bottomless gulph of wretchedness for ever." $[\mathrm{sic}]^{7}$ Rice wondered aloud, "Where is the sympathy, the tender

\footnotetext{
${ }^{6}$ Ibid, 7-8.

${ }^{7}$ Ibid, 8 .
} 
feelings of humanity? Where is the heart that does not melt at this scene of woe? Or that is not fired with indignation to see such injustice and cruelty countenanced by civilized nations, and supported by the sanction of law?" ${ }^{8}$ Like Hopkins, Rice believed that African slaves had the same claim to freedom that American patriots had and slavery was an injustice because the slave "has never forfeited his freedom" and is forced into obedience "to laws he never consented"9

He maintained that slavery made it impossible for Africans, who were equally created by God with freedom, to be at liberty to practice their religion in a nation ostensibly created on the foundation of freedom of religion. ${ }^{10}$ Rice also detailed the many other ways in which American slavery unjustly abrogated Africans' moral freedoms. $\mathrm{He}$ used the example of African women being violated by their masters: "A virtuous woman" who "esteems her chastity above every other thing" only to have it "forcibly" taken from her by her master, he "is treating her with the greatest injustice." A master could compel his slave "to steal or rob" or be punished for disobedience. He could also "deprive [a slave] of all the means of religious and moral instruction, either in private or in public" all with "the terror of the lash." The master ruled over the slave's potential for personal moral and educational improvement at "it is put out of their power to learn to read; and their master may restrain them from other means of information.” Rice observed that "Masters designedly keep their slaves in ignorance, lest they should become too knowing to answer their selfish purposes; and too wise to rest easy in their degraded situation."

\footnotetext{
${ }^{8}$ Ibid.

${ }^{9}$ Ibid.

${ }^{10}$ Ibid.
} 
Rice also cited instances where African families were destroyed by American slavery. He declared that African families were "formed by divine authority" but were immorally assaulted and invaded for the sake of the slave trade. "The principles of conjugal love and fidelity," Rice declared, "in the breast of a virtuous pair, of natural affection in parents, and a sense of duty in children, are inscribed there by the finger of God; they are the laws of heaven: but an inslaving [sic] law directly opposes them, and virtually forbids obedience." He was even more specific about how masters violated specific familial relations as well as relevant biblical laws. Regarding the marriage relationship, Rice proclaimed that, "The divine law says, ["] Whom God hath joined together, let no man put asunder ["]: the law of man says, to the master of the slave, ["] Though the divine law has joined them together, you may put them asunder when you please ["]. Here, Rice asserted that American slavery allowed masters to come between the sacred laws of marriage for the purpose of selling husband or wife. Likewise, regarding the responsibility of a parent toward a child, Rice argued, American slave owners meddled with the parental responsibility that Africans had toward their children. "The divine law says, ['] Train up your child in the way he should go['] the law of man says, [']You shall not train up your child, but as your master thinks proper.[']" In other words, the master could interfere by American law in the formative role and responsibility that a parent had toward the child. Lastly, American masters usurped any divine ordered relationship and fidelity from a child to his parents. On this subject Rice proclaimed, "The divine law says, [']Honour your father and mother, and obey them in all things[']: but the law of man says, [']Honour and obey your master in all things, and your parents just as far as he shall direct you.[']" In this case the master usurped the 
divinely sanctioned relationships within the African families in the process of establishing American slavery. ${ }^{11}$

Rice angrily asserted that African slaves were stolen from their homes, their families and their countries and treated with indignity in this nation. "They are stolen," Rice charged, "or violently borne away by armed force, from their country, their parents, and all their tender connections; treated with an indignity and indecency shameful to mention, and a cruelty shocking to all the tender feelings of humanity; and they and their posterity forced into a state of servitude and wretchedness for ever." ${ }^{12}$ To those who might justify the slave trade by positing that Africans captured and sold Africans, Rice would still lay the responsibility on Europeans. "It is true, they are commonly taken prisoners by Africans;" Rice conceded, "but it is the encouragement given by Europeans that tempts the Africans to carry on these unprovoked wars." ${ }^{13}$ Rice therefore argued that slavery should be outlawed and should not be ratified into the Kentuckian constitution.

Rice answered a key objection to the emancipation of slaves-the amalgamation of the races; by exposing what he believed was a greater evil—incest and intentional. He pointed out the common practice of white masters, and their progeny, impregnating their black slaves for the purposes of breeding more slaves. "How often" Rice asked, "men have children by their own slaves, by their fathers' slaves, or the slaves of their neighbours?" Conceding this amalgamation of the races as "evil", Rice pointed out that the current practice among slaveholders was more even more "disgraceful, and unnatural,

\footnotetext{
${ }^{11}$ Ibid, 6-7.

${ }^{12}$ Ibid, 15.

${ }^{13}$ Ibid.
} 
than intermarriages." Rice went into detail recounting a system more heinous and incestuous than the "evil" of intermarriage:

Fathers will have their own children for slaves, and leave them as an inheritance to their children. Men will possess their brothers and sisters as their property, leave them to their heirs, or sell them to strangers. Youth will have their grey headed uncles and aunts for slaves, call them their property, and transfer them to others. Men will humble their own sisters, or even their aunts, to gratify their lust. $^{14}$

Racial and relational lines were blurred in such an incestuous system. White men had sex with their black sisters to beget mulatto children to eventually be held and sold as property. The system confused and contorted even the slaveholder's view of what family lines existed in his own household. "An hard-hearted master will not know," Rice lamented, "whether he has a bold relation, a brother or a sister, an uncle or an aunt, or a stranger of Africa, under his scourging hand. This is not the work of imagination it has been frequently realized."15

Rice upheld the scriptures in contradiction to this incestuous practice. Unlike the slave codes that limited the status of Africans to the "condition of the mother," Rice asserted that in the Old Testament slaves were accepted and admitted into Hebrew families. Combining passages in Genesis 17 and Leviticus 25 Rice argued that Abraham welcomed slaves into his family through the rite of circumcision. Doing so, he made them eligible and heirs to Abraham and thus "suitable provision was made by the divine law that they should be properly educated, made free, and enjoy all the common privileges of citizens. ${ }^{.16}$ By employing this line of argument then, Rice asserted that

\footnotetext{
${ }^{14}$ Ibid, $17-18$.

${ }^{15}$ Ibid.

${ }^{16}$ Ibid, 19.
} 
Africans had every right to be treated as citizens and should therefore be allowed to access education, freedom and the civil liberties that accompany citizenship. He denied that the children of Africans could rightfully be denied these privileges just as the Law of Moses did not condemn the children of servants to chattel slavery. Rice maintained that if the Law of Moses allowed for the perpetual slavery of the first generation of slaves, it was limited to that generation and not to their progeny. "It cannot be necessarily implied in the expression," Rice explained, "They shall be your bondmen for ever; because the word for ever [sic] is evidently limited by the nature of the subject; and nothing appears, by which it can be more properly limited, than the life of the servants purchased. The sense then is simply this, they shall serve you and your children as long as they live."17 Rice therefore argued that the American notion of slavery that established that "the condition of the child followed that of the mother" was anathema to the scriptures.

In answer to those who might argue that the Bible sanctioned slavery, Rice denied that the scripture condemned people to perpetual slavery. "But it is further objected," Rice summarized the opposing argument, "That the Apostle advises servants to be contented with their state of servitude, and obedient to their masters; and, though he charges their masters to use them well, he nowhere commands them to set them free." 18 Here Rice alluded to the maxim that Paul laid down that "slaves should obey their masters." ${ }^{\prime 19}$ Rice countered that Paul was addressing slaves who were under Roman "heathen" rule "who were watching every opportunity of charging them with designs

\footnotetext{
${ }^{17}$ Ibid.

${ }^{18}$ Rice, Slavery inconsistent with justice and good policy, 20.

${ }^{19}$ Ibid.
} 
against their government, in order to justify their bloody persecutions. ${ }^{20}$ Rice reasoned that had Paul "proclaimed liberty to the slaves, [it] would have probably exposed many of them to certain destruction, brought ruin on the Christian cause, and that without the prospect of freeing one single man; which would have been the height of madness and cruelty." ${ }^{21}$ Rice reasoned that Paul was "wise" to not venture to say more on the subject than to advise "If thou mayest be made free, use it rather." 22

Rice added that Christians in the United States could and should, unlike Paul, openly call for the end of the unjust system that was American Slavery. Rice argued that the teachings of Jesus Christ demanded that the cruel system be abolished. "Though the Apostles acted with this prudent reserve," Rice reasoned, "the unreasonableness of perpetual unconditional slavery may easily be inferred from the righteous and benevolent doctrines and duties taught in the New Testament." Rice appealed to the higher teachings of Jesus Christ himself. "It is quite evident," Rice proclaimed, "that slavery is contrary to that excellent precept laid down by the divine Author of the Christian institution, viz. Whatsoever ye would that men should do to you, do ye even so to them." ${ }^{23}$ The Golden Rule, that ultimate scriptural maxim that abolitionists loved to quote, was a favorite arrow in the quiver of abolitionist arguments against American slavery. No white slave holder dared take the place of Africans in their debased condition. Rice dared any white man take the place of an African:

\footnotetext{
${ }^{20}$ Ibid.

${ }^{21}$ Ibid.

${ }^{22} \mathrm{Ibid}$, this is a reference to Paul's advice to slaves in I Corinthians 7:21 where he advises slaves that they should try to be content in their circumstances, but if they could they should try to obtain their freedom.

${ }^{23}$ Rice, Slavery inconsistent with justice and good policy, 20.
} 
A precept so finely calculated to teach the duties of justice, to inforce their obligation, and induce the mind to obedience, that nothing can excel it. No man, when he views the hardships, the sufferings, the excessive labours, the unreasonable chastisements, the separations between loving husbands and wives, between affectionate parents and children, can say, 'Were I in their place, I should be contented. I so far approve this usage, as to believe the law that subjects me to it is perfectly right; that I and my posterity should be denied the protection of law, and by it be exposed to suffer all these calamities; thought I never forfeited my freedom, nor merited such treatment, more than others. ${ }^{24}$

Like abolitionists predecessors, Rice warned that there would be a reckoning for American slavery. "The slavery of the Negroes," Rice warned, "began in iniquity; a curse has attended it, and curse will follow it." Rice further warned, "National vices will be punished with national calamities." He pleaded with his fellow Kentuckians that they should take heed. "Let us avoid these vices," Rice urged, "that we may avoid the punishment which they deserve; and endeavor to act, as to secure the approbation and smiles of Heaven." Rice hoped that his fellow Kentuckians would break away from Virginia not only as a separate state, but also free of the stain and "guilt" of the sin of American slavery. "Holding men in slavery is the national vice of Virginia; and, while a part of that state, we were partakers of the guilt. As a separate state, we are just now come to the birth; and it depends upon our free choice, whether we shall be born in this sin, or innocent of it." Rice believed American slavery to be a "national crime" and Kentuckians had a chance to repudiate that crime with their state constitution. "We now have it in our power," Rice declared, "to adopt it as our national crime; or to bear a national testimony against it. I hope the latter will be our choice; that we shall wash our hands of this guilt, and not leave it in the power of a future legislature, ever more to stain

\footnotetext{
${ }^{24}$ Ibid.
} 
our reputation or conscience with it." ${ }^{25}$ Despite Rice's impassioned speech, the lure of profits overcame notions of piety as the Kentucky convention promptly out voted him and his fellow antislavery advocates, $26-16$, and ushered in slavery into its state constitution in $1792 .{ }^{26}$

Even as American slavery staked its claim in Kentucky, Africans were smashing French slavery on the island of St. Domingue. The year before Kentucky's ratification of its slave-friendly constitution, Africans erupted throughout the island taking hold of cities, towns, provinces, plantations, mansions, and swallowed the very lives of their French masters in a bloody coup. In one fell swoop slavery no longer existed on the island. Despite losing one of their main leaders, Toussaint Louverture, to French capture, the former slaves resisted waves of Napoleon's military over the next twelve years to establish themselves as an independent nation. Frustrated by his shocking and devastating loss, Napoleon made an equally startling offer to U.S. officials of New Orleans for $\$ 10$ million. Napoleon's hasty offer was that for $\$ 15$ million the U.S. could have New Orleans and French Louisiana, the equal of 828,000 square miles and 530 million acres. Jefferson's envoy Robert Livingston promptly agreed. In an ironic turn of events, the U.S. had now in 1803 doubled in size making more land available for the diffusion of chattel slaves and the westward expansion of American slavery—all courtesy of the triumph of slave rebellion in St. Domingue. ${ }^{27}$

\footnotetext{
${ }^{25}$ Ibid, 24.

${ }^{26}$ Dumond, Antislavery, 61.

${ }^{27}$ Baptist, The Half has Never been Told, 44-47; C. L. R. James, The Black Jacobins; Toussaint L'Ouverture and the San Domingo Revolution (New York: Vintage Books, 1963); Laurent Dubois, Avengers of the New World: the story of the Haitian Revolution, (Cambridge, Mass: Belknap Press of Harvard University Press, 2004).
} 
While St. Domingue's uprising and the subsequent Louisiana Purchase opened new territory for the domestic slave trade to spread west, it was a harbinger of danger for some white Americans who used it to warn Americans of the potential for a reprisal on American soil. Thomas Branagan, a radical native of Dublin, and a former slave trader, overseer, and slaveholder, was suffering from pangs of conscience when he decided to write a confessional about the inner working of the slave trade. ${ }^{28}$ His time in Antigua had exposed him to horrid scenes that allowed him little sleep. Branagan left the business, immigrated to Philadelphia and formed a partnership with the Quakers to warn Americans of the injustice and dangerous potential of slavery. Starting in 1804 he published three successive tracts, A Preliminary Essay, Serious Remonstrances, Addressed to the Citizens of the Northern States, and The Penitential Tyrant. As a former slave trader Branagan's account amounted to a confessional and testimonial and therefore authoritative, especially in the light of the bloody rampage in St. Domingue. ${ }^{29}$ The scenes he recounted pained him greatly. "[W]hile I recollect the tragical scenes at which I have been present," Branagan recalled, "and in which, alas! I performed my part, my soul recoils; tremor seizes my whole frame; I can hardly restrain my knees from smiting one against another, while my blood hangs shivering in my veins." ${ }^{30}$ Branagan was tormented of the sinister ways in which he clandestinely moved among the Africans making the most of their "humanity and hospitality" while concocting ways to lure them into

\footnotetext{
${ }^{28}$ Betty Fladeland, Men and brothers; Anglo-American antislavery cooperation (Urbana: University of Illinois Press, 1972), 70; Dumond, Antislavery, 80; Branagan, Preliminary Essay, 29.

${ }^{29}$ Dumond, Antislavery, 80.

${ }^{30}$ Branagan, Preliminary Essay, 29.
} 
cooperation into the slave trade. He had become a master of intrigue deploying multiple strategies for acquiring Africans by "distributing among them toys, and trinkets, and ardent spirits, to purchase slaves" or "if they were not ready, to provoke the different nations to go to war, in order to procure them for us." ${ }^{31}$ His duplicity made Branagan feel dirty and deep self-loathing. "The dishonourable, base methods we used to accomplish our infernal designs," Branagan regretted, "are a disgrace to human nature. Every sentiment of honesty and honour we seemed totally to have forgot." 32

To Branagan the deceptive nature of the slave trade perpetrated on an unsuspecting and yet kind and hospitable people was a sin. He understood that among the Africans he was as a wolf among sheep disguised in sheep's clothing. "They, in the kindest manner," Branagan confessed, "invited me to their homely habitations, and treated me, not as an enemy, but as a friend; not as a stranger, but as a relative." That he returned their kindness with cruelty was a burden too horrible for his conscience to bear. African tears, "shrieks and lamentations" rang in Branagan's ears years after his cohorts tore "and dragged [them] from their happy country, and from their nearest and dearest relatives and connexions." ${ }^{.33} \mathrm{He}$ was tortured by his conscience. "Day and night my mind continues to be haunted," Branagan lamented, "by the image of those unhappy victims to our avarice and ambition." 34

${ }^{31}$ Ibid, 31.

${ }^{32}$ Ibid, 32.

${ }^{33} \mathrm{Ibid}, 32$.

${ }^{34}$ Ibid, 33. 
Like others who argued that the slave trade was intrusive of human rights, Branagan sought through his account to establish that divine authority stood opposed to the practice of dealing in humans. Striking a familiar chord and perhaps having been influenced by Sharp, another transatlantic abolitionist, Branagan sounded the alarm for Americans. "Hear this, ye American task masters," wrote Branagan, "hear and tremble. Verily there is a God that judgeth in the earth." Branagan continued that God not only judged the world, but he was not on the side of those who held power over Africans. Instead, "the sighs and groans of the oppressed he hears;" and Branagan wrote, "their stripes and wounds he feels." And lest the Americans feel secure, Branagan warned "And though for reasons best known to himself, he delays the execution of alarming threatenings and the infliction of his tremendous judgments, his determination to punish is fixed and irrevocable." He reminded them of a biblical verse. "Vengeance is mine, says he, and I will infallibly repay," Branagan cried. He argued, like Sharp, that other nations in antiquity had suffered divine retribution for their complicity with oppression. "On account of injustice and oppression," Branagan warned, "the most extensive, opulent, and powerful empires have been subverted; kingdoms and commonwealths overthrown; cities great and populous are now no more." 35

Like other antislavery writers Branagan argued that God was the defender of those who were vulnerable in society and that he heard their prayers for deliverance. $\mathrm{He}$ demanded of American slaveholders, "shall not He, who ever is the patron of the widow, the fatherless, and every other species of the afflicted of mankind avenge and deliver the

\footnotetext{
${ }^{35}$ Ibid, 16.
} 
unhappy sons and daughters of Africa, who, by their deep sighs and doleful groans, cry day and night unto him?" Branagan was unnerved by the thought that thousands African widows and orphans were crying to God against him and other oppressors like him. He was convinced that God heard their collective groans and avenge their affliction. Like other antislavery activists, Branagan described how the slave trade created widows and orphans and how he participated in that process. "Children are torn from their distracted parents;" Branagan remembered, "parents from their screaming children; wives from their frantic husbands; husbands from their violated wives; brothers from their loving sisters; sisters from their affectionate brothers." After separating kin, he recalled how the Africans were dehumanized and animalized on their way to the ships even as they resisted their captivity. "See them collected in flocks," Branagan wrote, "and, like a herd of swine, driven to the ships. They cry, they struggle, they resist; but all in vain." 36 Branagan remembered how the Africans cried and resisted "but all in vain" as they could nothing to prevent being forced into "the hold of the vessel" and in the process their "limbs, already wounded and lacerated, and bloody." To maximize space, large "numbers [of Africans] are compressed within so small a space" causing a miasma of death. Branagan recalled "that the air almost immediately becomes pestilential; from the putrid effluvia of which they contract diseases, which, in a very short time, terminate in death." Pity found little foothold among the slave traders for the suffering of the Africans had little emotional effect among them. Branagan confessed that his cohorts dispatched dead Africans "with the utmost indifference, [were] thrown overboard, to feed the monsters of the deep. Not one tear; not one sigh, on the occasion." Africans who survived endured the

\footnotetext{
${ }^{36}$ Ibid, 33.
} 
capricious and indiscriminant treatment of sadistic slave traders. "Survivors have I seen," Branagan remembered "[were] severely flogged for no reason, that I could perceive, but to gratify the infernal malevolence of those diabolical tyrants, who now had them perfectly in their power, and seemed to sport with their misery." The cruelty of slave traders included the pouring of scalding hot water on sick Africans to force them to move. $^{37}$

Branagan's account as a former slave trader, however, went beyond charging the slave trade with just oppression or sadism, he charged that it was mass murder. His accusation was not hyperbole. "The wretched Africans are not merely enslaved;" Branagan charged, "they are, in instances innumerable, oppressed, and starved, and tormented, and murdered." ${ }^{38}$ Describing the ordeal of Africans in the Middle Passage and what many would describe as collateral damage due to the rigors of the slave trade, Branagan also related what he believed were the results of the slave trade. "According to a calculation made by well-informed persons," Branagan wrote, "it is supposed, that of those, who are annually transported from Africa to the West-India settlements, not less than thirty thousand die, I ought rather to have said, are murdered, on their passage." 39 This new way of looking at the deaths of the slaves as "murders" had to be jarring for his readers. Branagan's way of looking at the demise of African victims of the slave trade led him to call for the criminalization of the murder of Africans in the slave trade or at the hands of a slave master. "Let the murder of a slave, no less than of another person," wrote

\footnotetext{
${ }^{37}$ Ibid, 34-35.

${ }^{38}$ Ibid, 29.

${ }^{39}$ Ibid, 35.
} 
Branagan, "be, by law, declared to be a capital crime; and the law ascertaining death to be the punishment of it, in the most rigid manner, excecuted." Branagan appealed to the scriptures for his authority for setting the proper punishment for the death of an African at the hands of a slave trader or master. "For this purpose, let the antediluvian law," Branagan declared, "Whosoever sheddeth man's blood, by man let his blood be shed, be put in full force. Let the inhuman, the irrational, the antiscriptural, the scandalous practice of the master atoning for the murder of a slave, by paying a certain sum of money, be known no more. ${ }^{40}$

The prospect of importing thousands upon thousands of men and women who were systematically victimized and made natural enemies frightened Americans. St. Domingue was the glaring example and the cautionary tale of the wages of importing an angry population. Add to that the notion that perhaps God would aid the Africans, rather than the Americans, was a very real fear for Americans. Thomas Jefferson said as much when he intimated that he did not see how God could do otherwise than to support the Africans in a bloody slave rebellion. Branagan's writings reflected for Americans that the African slave trade was not only an injustice but a menace to society; a danger for which they could not count on the help of God who takes the side of orphans, widows and the poor in their oppressed state. In his urgent caution to Americans Branagan borrowed the words of Thomas Jefferson who "trembled for [his] country":

"But, without cogent measures, the body politic must one day feel what I shudder even to think; for, as slavery began with a vengeance, as it has been continued with a vengeance to thousands of mariners annually destroyed in the slave-trade, by the cruelty of their captains, the inclemency of the climate, and by the Africans raising upon them to regain their liberty it will assuredly end (as in St. Domingo)

${ }^{40}$ Ibid, 123. 
with a vengeance. To expect any thing better, is to expect that God will alter the course of nature and perform a prodigy to save the traitors and tyrants of mankind. But, in order to illustrate this topic, we will transcribe an observation made by the greatest statesman and philosopher in America, who cannot be supposed to be prejudiced in favour of the African race:--'I tremble,' says he, 'I tremble for my country, when I remember that God is just; that his justice cannot sleep for ever; and that an exchange of circumstances is among probable events. The Almighty as no attribute which can take side with us in such a conflict.' Judicious, candid observation. The reasonableness of and truth of which is as clear to me as a ray of light - as plain as A, B, C; and they must be rogues or fools that will not see it. $^{41}$

Branagan believed the degraded, oppressed and provoked Africans posed a great threat to the domestic security of the newly formed United States. And he believed, like Jefferson, that Americans could not possibly hope that God would come to their aid should the Africans be emboldened to rise in bloody rebellion. St. Domingue stood as a cautionary example of what he warned.

Branagan's fears led him to propose the resettlement of freed Africans from mainland United States into the territories. He believed Africans posed a threat to American society. Beyond posing a violent threat, they also threatened the racial purity of white America. He warned of miscegenation and the "mongrelization" of the white race if Africans were not resettled somewhere far from where white America dwelled. Branagan's proposal was outlined in his tract titled Serious Remonstrances. His proposal however, does not engage the Bible as a rationale for his resettlement scheme. Unlike his reliance on scripture to make the case that God opposed the oppression of the Africans, in Serious Remonstrances Branagan sought to appeal to the "natural feelings and common

${ }^{41}$ Ibid, 233. 
sense" of Americans. He did not quote a single scripture in his 132 page tract to bolster his rationale or argument that Africans should be deported upon their emancipation. ${ }^{42}$ Louisiana residents were not heeding Branagan's warnings. Apparently a heavy influx of St. Domingue refugees and African slave imports did not register on the concern meter. There was a considerable hunger for African slaves. ${ }^{43}$ But by January 5, 1811 Americans faced the biggest slave rebellion in the United States before the Civil War. ${ }^{44}$ An army of slaves native to West Africa, Jamaica, Southern U.S. and St. Domingue conspired to sweep through New Orleans on a bloody rampage as had been done in Haiti. The Louisiana whites squelched the rebellion within a week making quick and severe work of the captured rebels. U.S. whites had several advantages that their counterparts on St. Domingue did not have. They were without the severe disadvantage in numbers and had the support of the federal government to suppress rebellions. Responding to the revolt slaveholders in Louisiana clamped down on the slaves with greater vigilance and regular sweeps of slave quarters to ensure that a repeat did not occur. Also, Louisiana saw their need for connection to the Union. They applied for statehood and were granted entrance as a slave state in $1812 .{ }^{45}$

If St. Domingue frightened some white Americans, it also inspired some opponents of slavery in the U.S. Some Americans sympathized with the Africans

\footnotetext{
${ }^{42}$ Branagan, Serious Remonstrances, 73.

${ }^{43}$ As Edward Baptist writes, "Seemingly unable to think beyond a playbook that had already ended in vengeance, Saint Domingue refugees and their French- and Spanish-speaking compatriots demanded more slaves," The Half has Never been Told, 51.

${ }^{44}$ Baptist, The Half has Never been Told, 57.

${ }^{45}$ Baptist, Half has Never been Told, 57-64.
} 
believing their revolution to be based on the same ideals of their own against Great

Britain. Such was the case in Kentucky when a group of ministers led by Barrow

belonging to the Baptist Elkhorn Association began to openly teach on emancipation. The association did not think it appropriate "of ministers, churches, or associations meddling with the subject of emancipation from slavery or any other political subject." 46 Barrow had come into a dispute with a member of his congregation over two slaves perhaps arguing that the slaves ought to be emancipated. ${ }^{47}$ The association censured and removed Barrow and the ministers from their positions. Although later reinstated, Barrow refused to be muzzled and wrote a polemic arguing that perpetual slavery was against the principles of nature, reason, justice, good policy and lastly, scripture. ${ }^{48}$

Barrow's main contention was the perpetual nature of American slavery. Barrow defined slavery:

When I use the words slave or slaves, I would be understood to mean such beings of the human race who are (without any crime committed by them, more than is common to all men) with their offspring to perpetual generations, considered legal property; compelled by superior force, unconditionally to obey the commands of their owners, to be bought and sold, to be given and received, to go and come, to marry or forbear, to be separated when married at pleasure, to eat, drink, sleep, war, labour, and to be beaten at their owner's discretion; and all this sanctioned by civil authority.- This is what I consider slavery, with a witness; and the propriety of this is what I am about to examine on the principles of Nature, Reason, Justice, Policy and Scripture. ${ }^{49}$

\footnotetext{
${ }^{46}$ Mark Fisher Miles, "Friends of Humanity: A Quaker Anti-Slavery Influence," Church History 4, no. 3 (1935): 187-202,194-195, http://www.jstor.org.ezproxy.fiu.edu/stable/3160844 (accessed June 29, 2016).

${ }^{47}$ Robert Hamilton Bishop, An outline of the history of the church in the state of Kentucky, 297.

${ }^{48}$ David Barrow, Involuntary, unmerited, perpetual, absolute, hereditary slavery, examined on the principles of nature, reason, justice, policy, and scripture (Lexington [Ky.]: Printed by D. \& C. Bradford, 1808), http://memory.loc.gov/award/icufaw/bbf0103/0001v.jpg (accessed July 2, 2016).

${ }^{49}$ Ibid, vi.
} 
David Barrow denied that Africans were bound by scripture to serve perpetually and that their children were also bound to such a term. He quoted Leviticus 25:10 and Exodus 21:6 to argue that among Jews slavery could not last more than 50 years or in the year of Jubilee. ${ }^{50} \mathrm{He}$ denied that children could be used in the same way arguing from Ezekiel 18 that forced slavery could only be used as a punishment for crimes and that the children could not be punished for the crimes of their parents. ${ }^{51}$ Barrow examined Noah's prophecy and after arguing that the curse only applied to Canaan, who he wrote did not settle in Africa, Barrow denied that it was also not perpetual for if it was "they must be still in slavery." 52 He related the story of Abraham and his slaves and also denied that Abraham held his slaves in perpetuity. He gave as proof that by arguing that "we read nothing of said servants, or their progeny, when his grandson Jacob, moved into Egypt;-though the number of souls, are particularly mentioned, who went down with that patriarch $[\ldots]$ not a servant, or bond-man or woman, mentioned in the whole can be gathered out of this account, in favour of - perpetual, hereditary slavery." ${ }^{, 53}$ Also on the subject of Abraham, Barrow argued that when he slept with his slave Hagar with his wife's full knowledge, the product of that union, Ishmael, was not treated as a slave or the property of his brother Isaac. The same was true in the story of Jacob's union with Bilhah and Zilpah the maidens belonging to Rachel and Leah, Jacob's wives. The children of those unions were treated as sons and not as slaves or property of their

\footnotetext{
${ }^{50}$ Ibid, vii.

${ }^{51}$ Ibid, vii.

${ }^{52}$ Ibid, $29,43$.

${ }^{53}$ Ibid, 29.
} 
siblings from Jacob's union with Rachel and Leah. ${ }^{54}$ Like Rice, Barrow argued that once the children of slaves were circumcised they could not be used rigorously because they were now considered members of the nation of Israel. ${ }^{55}$ Barrow attacked the slave trade by arguing that kidnapping was a sin and gave several biblical references concerning the practice that included Exodus 21:16 and 1 Timothy 1:9-10. ${ }^{56}$

Overall, Barrow contended that the whole "oppressive" institution, when instituted in perpetuity, was "highly offensive to God" and that such should be obvious "to those who are conversant with the Bible." ${ }^{57}$ Like some predecessors who used the Bible to attack American slavery, Barrow also warned of divine retribution. He feared that perpetual slavery would go on until "God be provoked, to avenge those suffering fellow-creatures of ours, who for ages have groaned under the heavy hand of oppression, the galling chains of abject slavery" and he warned that Americans "we may reasonably expect the visitation on our part, will be awful indeed!" Like Anthony Benezet he quoted Jeremiah 5: 9 and 29: "Shall I not visit for these things? Saith the Lord: and shall not my soul be avenged on such a nation as this[?]" 58 Despite his contention that perpetual slavery was against the Bible and was concerned about the possibility of divine retribution, Barrow was not an immediatist calling for the immediate emancipation of all

\footnotetext{
${ }^{54}$ Ibid, 30-31.

${ }^{55}$ Ibid, 31-32.

${ }^{56} \mathrm{Ibid}, 33$.

${ }^{57}$ Ibid, 37.

${ }^{58}$ Ibid, 42.
} 
slaves. "I do not know one among us," Barrow wrote, "who is in favour of an immediate general emancipation.” Barrow concluded that emancipation,

will require time, to prepare those sons and daughters of wretchedness, to receive the blessings of liberty, as well as to remove the prejudices, etc. of the citizens in general. $^{59}$

If the Southern states won a Constitutional mandate to diffuse and spread slavery into the territories, they did still meet with opposition. Antislavery activists and preachers like Thomas Branagan, David Rice and David Barrow raised issues of conscience and deployed the scriptures to make the case that American slavery was immoral and harmful to the republic. They believed and predicted that there would be divine retribution for slavery. As such they vehemently opposed the spread of American slavery into the territories or its ratification into state constitutions. Yet, their protests were rather disparate. They were not part of a movement nor were they catalysts to start a movement. That reformist voice would soon arrive from across the Atlantic.

${ }^{59}$ Ibid, 42. 


\section{CHAPTER IV}

\section{George Bourne, the Bible and the Roots of Nineteenth-Century Immediate Abolitionism}

In 1812 George Bourne had been at Rockingham County, Virginia, leading the Presbyterian Church for about three years. The congregation, growing increasingly hostile to his critique of slavery, asked him to preach on the eighth commandment against stealing. His specific assignment was to apply the passage to the slaves who had been pilfering such items as poultry from their masters. Bourne complied with a message that first counseled the slaves against stealing chickens. But then he sent shockwaves throughout the congregation when he pivoted his attention to the masters among the congregants. To them he posed the question: If stealing chickens "was a sin," what did they think of "stealing" human beings from Africa who made were in the image of God? Which "sin" was greater in their estimation? What, he further asked, did they think of "stealing" humans from their families and communities in Africa simply because of the color of their skin? He also inquired what they thought of reselling the stolen human beings, and their children, within the American system of slavery. The congregation's reaction was visceral. The countenances of his parishioners quickly hardened as anger swept over the congregation. Incensed congregants leaped to their feet and surrounded the young preacher after the service was over. Undaunted, the young antislavery firebrand neither recanted nor was silenced. Instead, he wrote and self-published his first book, The Book and Slavery Irreconcilable, detailing how slavery ran afoul of the scriptures. $^{1}$

\footnotetext{
${ }^{1}$ Theodore Bourne, Rev. George Bourne : the pioneer of American antislavery, [Louisville, Ky.], [1882], Slavery and Anti-Slavery, Gale, Florida International University, 22 Oct. 2016, 74.
} 
Most scholars agree that the American radical immediatist chapter of the abolitionist movement began in earnest during the early $1830 \mathrm{~s}^{2}$ At this time, the American Anti-Slavery Society (AASS), the first American national abolitionist organization, was established and William Lloyd Garrison emerged as the movement's iconic leader. ${ }^{3}$ Very few scholars, however, have identified George Bourne as either a key contributor to the 1830 s movement or traced his abolitionist convictions, which he held at least 20 years before the AASS was formed in $1833 .{ }^{4}$ As early as 1812 , Bourne preached, wrote, and stood against American slavery, called for its immediate abolition, and put forward a biblical framework and vocabulary that would be used twenty years later in the national call for the immediate end of American slavery. Of course, immediatism did not begin with him. Samuel Hopkins and Granville Sharp had called for the immediate end of slavery in 1776. But Bourne used a vocabulary of manstealing that would be applied to Americans slavery two decades later when the nineteenth-century national movement began in earnest.

\footnotetext{
${ }^{2}$ Richard Newman, The Transformation of American Abolitionism: Fighting Slavery in the Early Republic (Chapel Hill and London: University of North Carolina Press, 2002), 2; Gilbert Barnes, The Antislavery Impulse, 1830-1844 (Gloucester, Mass: P. Smith, 1973), 55; John L. Thomas, The Liberator, William Lloyd Garrison: A Biography (Boston: Little, Brown \& Company, 1963), 3-5; Bertram Wyatt-Brown, Lewis Tappan and the Evangelical War against Slavery (New York: Atheneum, 1971), 80-81; Nell I. Painter, Sojourner Truth: A Life, a Symbol (New York, 1996), 64-65; Lewis Perry, Radical Abolitionism: Radical Abolitionism: Anarchy and the Government of God in Antislavery Thought (Knoxville: University of Tennessee Press: 1995), 9; David F. Ericson, The Debate over Slavery: Antislavery and Proslavery Liberalism in Antebellum America (New York: New York University Press, 2000), 18. For a dissenting view of this argument see Dwight Lowell Dumond, Antislavery: The Crusade for Freedom in America (Ann Arbor: The University of Michigan Press, 1961), 175; John W. Christie, Dwight Lowell Dumond, and George Bourne, George Bourne and the Book and slavery irreconcilable (Wilmington: Historical Society of Delaware, 1969); Kenneth P. Minkema and Harry S. Stout in "The Edwardsean Tradition and the Antislavery Debate, 1740-1865," The Journal of American History 92, (June, 2005),: 47-74. Stanley K. Schultz's “The Making of a Reformer: The Reverend Samuel Hopkins as an Eighteenth-Century Abolitionist," Proceedings of the American Philosophical Society 5 (Oct. 15, 1971): 350-65.

${ }^{3}$ Barnes, Antislavery Impulse, 56-58.

${ }^{4}$ Bourne, The Book and Slavery; Theodore Bourne, Rev. George Bourne, 74; Dumond, Bourne and the Book and Slavery Irreconcilable, 50.
} 
Bourne's arrival in Virginia was on the heels of the close of the international slave trade on two fronts in the Atlantic. First, the British Parliament had passed the Slave Trade Act of 1807 which abolished the slave trade within the British Empire in the Atlantic. Secondly, the United States, in accordance with the Constitutional mandate to allow the international slave trade to continue unmolested for 20 years, brought the international slave trade to a legal end by passing the Act Prohibiting the Importation of Slaves of 1807 to go into effect on January 1, 1808. Slavery continued in the British Empire and the American domestic slave trade continued unabated to fuel southern expansion westward.

Born on June 13, 1780 in Wiltshire England, Bourne had descended from martyrs and members of the Reformation. His father, Samuel Bourne, was a 30 year deacon of the Congregational Church in Westbury, England; while his mother, Mary Rogers, was descended of martyrs during Queen Mary's persecution of Protestants during the $16^{\text {th }}$ century. Growing up, he was drawn to discussions on slavery and slave trade in Great Britain led by British abolitionists like William Wilberforce, Thomas Clarkson and others. For some time, Bourne helped his father in the family clothing manufacturing business; however, after some contemplation, he decided instead that his life's work was to prepare and enter the ministry. Soon after marriage on September 6, 1804 he immigrated to the United States. After some time in New York and Baltimore he settled in Virginia in 1809 where he led a Presbyterian church in Rockingham County. There he witnessed American slavery and would become a critic of it for the rest of his life. ${ }^{5}$

\footnotetext{
${ }^{5}$ Ibid, 73.
} 
Upon reaching Virginia, Bourne came face to face with an institution fueled by the domestic slave trade and protected by fugitive slave laws. Although he was familiar with slavery through the antislavery debates Bourne did not begin his ministry as an avowed abolitionist. Indeed he admitted that he once owned a slave. ${ }^{6}$ His antislavery views, however, evolved dramatically upon arriving in Virginia. While leading the Presbyterian church in Rockingham Bourne witnessed aspects of American slavery that deeply disturbed him. The oppression bewildered him as a British immigrant to the United States - a nation ostensibly established on the premise of equality and freedom. His decision to come to the United States, after all, was based on his belief that he could enjoy greater freedom of conscience than he could in Great Britain. ${ }^{7}$ Now, however, he was confronted with the nagging question of how such deep oppression could persist in the "land of the free." He wondered aloud how oppressions that were ten times worse than those found in Egypt could have gained traction in a nation that, less than 40 years earlier, declared all men to be created equal. ${ }^{8}$ What Bourne learned from 1809 to 1815 , about the realities of slavery, gave him great pause and challenged him to look to the Bible for answers. These realities of slavery also compelled him to speak out - to his own great peril.

First and foremost, Bourne attacked what he believed to be the number one sin of American slavery: human theft. The term "Manstealing" was a favorite of Bourne's as he

\footnotetext{
${ }^{6}$ Dumond, Bourne and the Book and Slavery Irreconcilable, 6.

${ }^{7}$ Dumond, Bourne and the Book and Slavery Irreconcilable, 6; Theodore Bourne, "Rev. George Bourne: The Pioneer of American Antislavery," 72.

${ }^{8}$ Dumond, Bourne and the Book and Slavery Irreconcilable, 6; Theodore Bourne, "Rev. George Bourne: The Pioneer of American Antislavery," 72; Bourne, The Book and Slavery, 16.
} 
railed against the institution. He argued that every enslaved African who reached American soil had been kidnapped and stolen from Africa. Since each individual was made in the image of God as a "lord over the earth" with the right to benefit from the works of their hands, they were stolen from their rightful selves. He also asserted that the children of such persons being held in bondage, was stolen from their parents to whom they were born. This theft, Bourne argued, was a violation of the Eighth Commandment which forbids stealing. Bourne made no distinction between slaveholder and the slave trader. For him, the one holding or selling someone in bondage in America was equally culpable as the one who kidnapped and sold them from Africa. He believed that the Bible, the major denominations, and the Bill of Rights stood in opposition to American slavery. ${ }^{9}$

Bourne also averred that enslaved Africans should be considered and treated as "neighbors" and "brothers" in a nation where by and large enslaved Africans were not considered as such. ${ }^{10} \mathrm{~A}$ view of the enslaved Africans as neighbors and brothers therefore made American slavery theologically problematic. Bourne maintained that American slavery was "irreconcilable" to the teachings of Jesus Christ. "The denunciations of the sacred volume," Bourne asserted, "must not be mitigated [and] the consequent exhibition[s] of unholy conduct are totally incompatible with the instructions and the example of Jesus of Nazareth and his Apostles; a direct and incessant violation of the eighth commandment cannot be compounded with the rectitude which Christianity

\footnotetext{
${ }^{9}$ Bourne, The Book and Slavery, 3.

${ }^{10} \mathrm{Ibid}, 6,7$.
} 
enjoins." ${ }^{11}$ Bourne wondered aloud, therefore, why would anyone who stole his brother shall be considered a Christian. ${ }^{12}$ Such a stance was problematic in Virginia in which enslaved Africans were debased and treated less than brothers.

Virginia led the nation in diffusing slaves into the new territories. According to Michael Tadman, Virginia sold off 41,097 enslaved African Americans between 1800 and 1809. The closest state behind Virginia was Maryland who sold off 19,960 in that same time period. And Virginia was just getting their momentum going as their numbers would grow steadily up to the Civil War reaching their peak of 118,474 in the 1830s and never dropping below 75,562. No state ever surpassed Virginia's contribution of sold humans into the domestic slave trade. ${ }^{13}$ So when Bourne landed in Virginia he witnessed the emerging stages of a slave trade that was focused on commodifying humans into U.S. regions that produced cotton and sugar for other nations. This machinery of commodification was the result of plantation owners, slaveholders, overseers and slave traders who colluded to make merchandise of the enslaved. An essential part of the commodification of the enslaved was their dehumanization. Since the Virginians had been working on diffusing their slaves as early as 1790 , the practice had by 1809 become part of their slaveholding culture for two decades. Virginians had thus grown accustomed to and were becoming adept at the multifarious aspects of the trade. The practice of growing and diffusing enslaved humans had embedded itself into their culture.

\footnotetext{
${ }^{11}$ Ibid, 5-6.

${ }^{12}$ Ibid, 7.

${ }^{13}$ Michael Tadman, "The Interregional Slave Trade in the History and Myth-Making of the U.S. South," in The Chattel Principle: Internal Slave Trades in the Americas, Ed. Walter Johnson (Yale University Press: New Haven, 2004), 120.
} 
Formerly enslaved Africans raised this issue of dehumanization. Although sources are limited because the enslaved were often unlettered, slave narratives and interviews with former slaves show that the problem of degradation and dehumanization as slaves was a source of continued pain for the enslaved. Former slaves recalled how they were dehumanized and treated as animals by the ways they were worked, disciplined, fed, clothed, bred, separated from family, inspected and sold at auctions and even as they were emancipated. ${ }^{14}$ Scholars have noted the view of white Americans toward the enslaved, their social death and the inhuman conditions under which the enslaved toiled in the antebellum period. ${ }^{15}$

Bourne noted the dehumanization of the enslaved in Virginia from 1809 to 1815. Slave owners, in many cases fellow congregants, spoke offhandedly of the enslaved as if animals. They spoke of "damaged slaves" as if a "damaged horse." They sought to purchase some "working slaves" while also acquiring "breeding slaves." They traded enslaved women for "a Ram and Sheep.” Bourne saw scantily dressed enslaved women prepared to be sold as "breeding wenches," who were intrusively inspected and later weighed on a scale to be sold "by the pound." Bourne was shocked to find that cash rewards were given to encourage breeding and "amalgamation" of the enslaved to be placed for sale. The "amalgamation" of the enslaved involved a breeding process that involved race mixing, that is sex between a white male owner, his son or an overseer and

\footnotetext{
${ }^{14}$ Mia E. Bay, The White Image in the Black Mind (New York: Oxford University Press: 2000), 117-149.

${ }^{15}$ Orlando Patterson, Slavery and Social Death: A Comparative Study (Cambridge Mass.: Harvard University Press, 1982), 5-9; David Brion Davis, Inhuman Bondage (New York: Oxford University Press), 3; Winthrop Jordan, White Over Black: American Attitudes toward the Negro, 1550-1812 (Chapel Hill: University of North Carolina Press, 1968), 29, 30; Jan Nederveen Pieterse, White on Black: Images of Africa and Blacks in Western Popular Culture (New Haven, Conn.: Yale University Press, 1992), 43.
} 
an enslaved woman to create mulatto slaves that could later be sold. Slaves, representing wealth for slave owners, naturally brought wealth upon the multiplication of their numbers on the planation. As such, it was not outside the possibility for them to be intentionally bred for that very purpose. Bourne not only bore witness to dehumanization of the enslaved, he conversed with members of his congregation and other Virginians and was informed of the extent of it in Virginia. ${ }^{16}$

At first blush, the notion of the "amalgamation" of enslaved African Americans would seem to be farfetched, extreme or voyeuristic. Scholars have noted that abolitionists seemed to obsess with the sexual sins of slaveholders. ${ }^{17}$ Scholars have also noted, however, that sexual exploitation was not a figment of abolitionist imagination. ${ }^{18}$ Former slaves themselves noted they were intentionally bred on the plantation according to their body types. ${ }^{19}$ Demand in the domestic slave market for enslaved mulattoes to be used as concubines has also been documented. ${ }^{20}$ The enslaved, after all, were considered by U.S. law to be property and without rights as citizens. There have been competing

${ }^{16}$ Dumond, Bourne and the Book and Slavery Irreconcilable, 6; Theodore Bourne, "Rev. George Bourne: The Pioneer of American Antislavery," 72; Bourne, The Book and Slavery, 16, 88, 110.

${ }^{17}$ Carol Lasser, "Voyeuristic Abolitionism: Sex, Gender, and the Transformation of Antislavery Rhetoric," Journal of the Early Republic 28, no. 1 (2008): 83-114. http://www.jstor.org.ezproxy.fiu.edu/stable/3004357, 93, (accessed February 28, 2017); Ronald Walters, "The Erotic South: Civilization and Sexuality in American Abolitionism," American Quarterly 25, May 1973, 177-201.

${ }^{18}$ Gregory D. Smithers, Slave Breeding: Sex, Violence, and Memory in African American History (Gainesville: University of Florida Press, 2012); Baptist, The Half Has Never Been Told, 240.

${ }^{19}$ Bay, The White Image, 130.

${ }^{20}$ Solomon Northup, Twelve years a slave: narrative of Solomon Northup, a citizen of New-York, kidnapped in Washington City in 1841, and rescued in 1853, from a cotton plantation near the Red River, in Louisiana, Auburn, 1853, 52, 86-87, Slavery and Anti-Slavery, Gale, Florida International University (accessed 28 Feb. 2017); Deborah G. White, Ar'n't I a woman?: Female slaves in the plantation South (New York: W.W. Norton, 1999), 36-37; Walter Johnson, Soul by Soul, 113; Edward Baptist, The Half Has Never Been Told, 240-243. 
studies considering the possibility of systematic breeding in the Upper South for the Lower South. ${ }^{21}$ But whether breeding was intentional or systematic, the practice was not illegal since the enslaved were considered and could be treated as chattel property. As chattel slaves they could be bought and sold at will. The enslaved could therefore also be purposely, if not systematically, bred to satisfy an existing niche market for mulatto girls. Enslaved mulattoes were marketed and sold by their traders as "fancy girls" or "fancy maids." 22 As one slave trader gleefully announced to a fellow trader, "I sold your fancy maid Alice for $\$ 800$. There are great demand for fancy maid. I do believe that a likely Girl \& a good seamstress could be sold for $\$ 1100 .{ }^{23}$ If they were selling them in 1833 , it is probable they were growing them in 1812 on the Virginia plantations.

Instances of "amalgamation" became apparent to Bourne who was revolted by the prospect that enslaved persons were being bred on plantations of Virginia like cattle. As a preacher he was incensed to find that the breeding and amalgamation took place through fornication, adultery and incest for economic purposes. He recalled what one Virginia plantation owner, whose identity he chose to obscure, did on his plantation and he applied the words of the Prophets Amos and Joel to the twisted scenes:

"In the lower counties of Virginia, this white-washing system and these amalgamating processes were carried on to a diabolical perfection. A picture of one plantation will serve for the whole... Major E is too cunning to buy negroes; he breeds and sells them... The language of the Prophets Joel and Amos here rightly may be applied; and in all the sacred solemnity of divine inspiration, they

\footnotetext{
${ }^{21}$ Richard G. Lowe and Randolph B. Campbell, "The Slave-Breeding Hypothesis: A Demographic Comment on the "Buying" and "Selling" States," The Journal of Southern History 42, no. 3 (1976): 401-12. doi:10.2307/2207159, (accessed February 25, 2017); Dumond, Antislavery, 68-70.

22 Baptist, The Half Has Never Been Told, 240.

23 Isaac Franklin to Rice Ballard November 1, 1833, quoted by Baptist in The Half Has Never Been Told, 239.
} 
furnish a clue into the slave-trader's labyrinth. 'They have cast lots for my people, and have given a boy for a harlot, and a girl for wine that they may drink.' Joel $3: 3$. 'A man and his father will go in unto the same maid, to profane my holy name.' Amos 2:7. ${ }^{24}$

Bourne used the terms "amalgamation" and "white-washing" to censure the breeding process employed by plantation owners; not because he was concerned about the "purity" of the white race, but because he was critical of plantation owners' intent to "clear his plantation of every real [sic] African.” Bourne observed that plantation owners kept a small "stock" of full blooded Africans which he made available to "regular slave dealers" while he sold off those who demonstrated some form of "debility or discontent." Bourne called this system of breeding the enslaved a "labyrinth" and abjured the intentional and sometimes meticulous ways in which the enslaved were bred to be sold. ${ }^{25}$

The gradation system Bourne found was akin to perfecting a certain breed of cattle further troubled him. Plantation owners sought to create a certain breed of slave whose economic worth rose according to the slave's "final tinge." To that extent, according to Bourne, plantation owners were willing to lend the sons, overseers, even themselves, to the breeding process in order to produce a breed of slaves whose value rose with the lighter black skin of the slave. Bourne charged that the continued intergenerational "regular system" relied on incest for its breeding and the passivity of white women. "It was manifest," Bourne found, "that there is scarcely a gradation in the crime of incest, to say nothing of the minor offences, which was not constantly and openly perpetrated, if not actually before the eyes, evidently within the knowledge of his

\footnotetext{
${ }^{24}$ George Bourne, Picture of slavery in the United States of America, Middletown, Conn., 1834, 95, Slavery and Anti-Slavery, Gale, Florida International University (accessed July 10, 2016). ${ }^{25}$ Ibid.
} 
wife and daughters." One Virginia woman explained their role in what transpired on her plantation. "We are called wives," the woman explained, "and as such are recognized in law; but we are little more than superintendents of a coloured seraglio." 26

Another aspect of the dehumanization of the enslaved was the savage beatings that they received. No one was spared the whip. The beatings had a dual purpose. They were designed to shape behavior in the one being chastened and the ones observing the whipping. Edward Baptist has noted how whippings were used to extract more productivity from slaves who picked cotton from 1790 to $1860 .{ }^{27}$ The dual purpose for the floggings, as Bourne described them, was to at once teach a lesson to other slaves and soften resistance to the overseer's lust. "On the slave plantations," Bourne wrote, "not only men and boys, but women and girls are often scourged in rotation, not for any real, alleged, or even pretended fault, but merely for the sake of example and that all the gang may remember the lacerations and tortures." But that was not all. Bourne contended that the whippings were administered to soften the resistance of enslaved women to the sexual advances of the white men on the plantation. Bourne continued that the whippings "provided the slave-driver or his overseer, to gratify lust, or satiate revenge, or fiend-like, from sheer love of mischief, choose to direct that the lash and stripes shall be inflicted." 28 He described how a friend "discovered a coloured woman naked to the loins, tied by the neck to the rail of a fence, and her feet similarly pinioned below; while S. was lacerating her with the cowskin or hickory rod in his hand." Furthermore, Bourne decried how so-

\footnotetext{
${ }^{26}$ Ibid, $96,92$.

${ }^{27}$ Baptist, The Half has Never been told, 131-135.

${ }^{28}$ Bourne, Picture of Slavery, 99.
} 
called Christians would whip their slaves mercilessly and carry on innocently in church services. He retold a story of a man who often stripped his female slave and "tied them to the rafters of his house, scourged them, left them there fastened" while he went to church service, preached, and returned to the same enslaved woman still so tied, to continue the flogging until he was completely satisfied or tired. Bourne wondered how such a man was never censured or called to account for his merciless cruelty. Bourne wondered how so-called Christians could blend "torturing girls and preaching Christian love."29

The torture of the enslaved had severe consequences to their bodies while the law allowed slave owners to get away with torture and the severe mutilation of their slaves. Slave narratives document instances of brutal beatings suffered by the enslaved. Solomon Northup described the brutal beating of Patsey in which she was stripped, tied to four pegs on the ground and beaten until her skin from her back was flayed and the blood flowed. Frederick Douglass recollected when as a young boy he witnessed the whipping of his aunt, a slave, and the blood that dripped unto the floor from her hanging body. ${ }^{30}$ In Virginia one owner beat his female slave so severely that the woman died. The woman's legs, according to Bourne, were "literally cut in pieces." ${ }^{31}$ After a protracted trial, the man was acquitted after his lawyer argued that the woman had not received more than the required number of lashes and that she was his property just as much as "a sheep." As a

\footnotetext{
${ }^{29}$ Ibid, 95 .

30 "CHAPTER XVIII," In Twelve Years a Slave: Narrative of Solomon Northup, a Citizen of New-York, Kidnapped in Washington City in 1841, and Rescued in 1853, edited by Wilson David, by Northrup Solomon, 167-75. University of North Carolina Press, 2011. doi:10.5149/9780807869444_northup, 21, 170-173 (accessed February 25, 2017; Frederick Douglass, Narrative of the Life of Frederick Douglass, in Henry Louis Gates, ed., The Classic slave narratives (New York, N.Y., U.S.A.: Penguin, 1987), 343-344.

${ }^{31}$ Bourne, Picture of Slavery, 122.
} 
sidebar, the attorney lamented during his closing argument that times had changed, for in his time and where he was from in Virginia it was "considered the greatest notice of a gentleman for killing a Negro!"32 Bourne conjectured that the ability to prosecute the murder of an enslaved woman was nearly impossible based on the difficulty of acquiring the necessary evidence to convict an owner of the murder of his property. ${ }^{33}$

Because the enslaved were considered property, there was no level to which they could be leveled in the world of their owners. Mia Bay has noted how "chattel slavery gave white people license to treat black people like beasts. The institution [of slavery] itself drew a line between the races that seemed to allow for the humanity of only one race." ${ }^{34}$ Virginia slaveowners took it a step lower by treating their enslaved as literal gambling chips. Bourne was shocked to find that enslaved Africans were further degraded when used by their owners as gambling chips. The crime was further exacerbated when the enslaved who were gambled away were in fact the biological children of the losing gambler. "Slaves are articles of gambling. Men, women and children,” Bourne lamented, "often the dissolute lawless profligate's own adulterous progeny, are transferred form one domestic tyrant to another, by the turn of a card, or the shake of the dice, or the fleetness of a horse, or any of the other numerous mods of fraud and robbery, which these debauched gamesters have invented to swindle each other with

\footnotetext{
${ }^{32}$ Ibid.

${ }^{33}$ Ibid.

${ }^{34}$ Mia Bay, The White Image in the Black Mind: African-American Ideas About White People, 1830-1925 (New York: Oxford University Press, 2000), 119.
} 
impunity $[\ldots]^{\prime 35}$ This practice, Bourne decried, was a practice in Washington of members of Congress who were supposedly "dignified citizens". Instead, Bourne wondered, were they not "speculating, predatory freebooters?"36 Dignified lawmakers were not limited to using their slaves as gambling chips, they used their slaves to pay off heavy gambling debts. Bourne related the story of a member of the Virginia legislature who purchased a mulatto girl, beat her "mercilessly" until she succumbed to his desires, and had several children with her. After a gambling dispute in which he was forced to give up the enslaved woman and her children, he was later able to recover them because of "the quirks of law." ${ }^{37}$

The dehumanization of the enslaved also involved their commodification and with good reason. The enslaved were valuable property to their owners, even if they treated them like less than humans. Over the course of the early nineteenth-century, slave values rose three-fold and reached prices as high as $\$ 1,800$ and in some cases $\$ 5,000$. In today's prices that could be between $\$ 30,000$ and upwards. ${ }^{38}$ Such prices made the enslaved a valuable, if degraded, commodity. Their collective worth in 1860 reached $\$ 3$ billion. As such, slave owners had incentive to disregard their relations because of their economic value. The auction block, therefore, was where the payoff was. The auction block, however, was where families were destroyed and Bourne was deeply troubled to witness

\footnotetext{
${ }^{35}$ Ibid, 121.

${ }^{36} \mathrm{Ibid}$.

${ }^{37}$ Ibid.

${ }^{38}$ Steven Deyle, "The Domestic Slave Trade in America: The Lifeblood of the Southern Slave System," in Chattel Principle, 95; Baptist, The Half Has Never Been Told, 239; Daina Ramey Berry, "We'm Fus Rate Bargain": Value, Labor, and Price in a Georgia Slave Community" in The Chattel Principle, 59-64.
} 
the disintegration of enslaved families on the plantation. Parental authority among the enslaved was completely usurped as they became grist for the machinations of the plantation owner who preempted their authority as he made arbitrary financial decisions affecting their families. Thus "all maternal and parental and pure domestic feelings," Bourne lamented, "wither and die.” The sexual appetites of slave owners also preempted the "natural authority" of enslaved parents by impregnating and having children with enslaved women and making unilateral decisions about their offspring offering them for sale. It was the sum of these types of actions that Bourne called "an abominable traffic" and the "attempt to vindicate or even to palliate it" that drove him suggest that these practices did not originate with Christ but rather "Devils." 39 While Bourne's accusations seem to be inconceivable, two things must be kept in focus: these are pictures that he maintained he witnessed or heard of happening while he ministered in Virginia — and they were legal. The families of the enslaved were not spared by the domestic slave trade. As Michael Tadman has concluded, "one in five marriages would have been destroyed by the trade and one in three children aged under fourteen years would have been separated from one or more parents. $" 40$

Bourne was appalled by the heart-wrenching scenes at public auctions in which humans and cattle were dually placed for sale. "They are always advertised together," Bourne protested, "and the descriptions are in the same beastly style, 'young, sound, without fault,' \&c." [sic] ${ }^{41}$ Like cattle the victims of the domestic slave trade were

\footnotetext{
${ }^{39}$ Bourne, Picture of Slavery, 32.

${ }^{40}$ Tadman, "Interregional slave trade of the U.S. South," in The Chattel Principle, 131.

${ }^{41}$ Bourne, Picture of Slavery, 111.
} 
offered for sale. The enslaved Africans were put out "half covered with rags, and loaded with chains" to be "sold and bought" and "bartered off like brute animals!"42 Though the slaves were dehumanized and treated like "brute animals" Bourne sought to humanize the faceless souls being sold into bondage. He related the scene described to him by a friend from Virginia. "Draw near to that wretched group," his friend implored, "Great have been their sufferings; but still they have feelings $[\ldots]$ Their minds are revolving those hideous pictures of Carolina and Georgia cruelty [...] The whole prospect of future of future life to them is dismal, dark and frightful. Soon the only tie which binds them to life is to be severed. See the convulsive embrace! [I]t is the last expression of connubial love, their last, long farewell.." ${ }^{23}$ Bourne sought to shed light not only on the dismal thoughts of the enslaved being sold, he also shed light on the families being destroyed by the slave trade. "This is but the beginning of misery. Those visages of grief indicate the desolation of whole families, all are dragged from each other, husband from wife, mother from child, father from son, and brother from sister, never more to meet on the earth." ${ }^{" 44}$ The pain experienced by enslaved families was not limited to separation, it was the trauma caused by their being torn apart. "Hark!" cried Bourne's friend, "[T]hose groans and shrieks and plaints of wo are the language of wretchedness, distracted love, and wild despair." ${ }^{45}$

Since the enslaved were such a valuable commodity, owners fiercely guarded their property. As a result, runaways were hunted like animals. To protect slaveholders'

\footnotetext{
${ }^{42}$ Ibid.

${ }^{43}$ Ibid.

${ }^{44}$ Ibid.

${ }^{45}$ Ibid, 111-112.
} 
property in humans, drafters of the Constitution gave them the right to pursue fugitive slaves anywhere in the Union, even as they required the African slave trade to sunset in 1808. Bourne equated the fugitive slave laws with the practice of kidnapping free Africans for the African slave trade. The former was law of the land, the latter was now outlawed. "The pursuit and seizure of a runaway slave," Bourne declared, "as he is disgracefully denominated, is equally as direct and ruffian kidnapping as it is to sail to Liberia, raise a palaver, with 'rum, guns, and gunpowder,' storm a village, then steal every defenceless African in the vicinity, and ship them to Charleston or Savannah." ${ }^{\prime 46}$ The equating of the two practices hinged, in Bourne's mind, on the fundamental principle that Africans had a basic human right to their own freedom.

Bourne also maintained that the Fugitive slave laws kept slaves in bondage and that those who enforced those laws cooperated in maintaining a whole race of people in bondage against the precepts of the Bible. He wrote:

Every public officer who aids to arrest and every Magistrate or Judge wo delivers his sentence, by which the coloured citizen who has escaped from the American 'house of bondage,' is again forced to return to 'the land of Egypt,' to experience all its terrors and anguish, and to wither and die amid its inexpressible toils and tortures, is not only guilty of willful and corrupt perjury; but he is a daring violator of the divine commandment, Deuteronomy 23:15, which peremptorily enjoins: 'thou shalt not deliver unto his master, the servant who is escaped from his master unto thee. ${ }^{, 47}$

Bourne found it unbelievable that the highest and more venerated body of laws in the world encouraged the practice of American slavery. Bourne attacked the U.S.

Constitution and its compromises on slavery believing that the law of God held more

\footnotetext{
${ }^{46}$ Ibid, 117.

${ }^{47}$ Ibid, $117-118$.
} 
authority. "The laws of Congress upon this subject," Bourne cried, "are now, as they always have been, utterly null and void; being directly opposed to the supreme law of Jehovah; and no Christian ever did or possibly can conscientiously execute them." The laws of God according to Bourne were designed to protect people. Any human law, therefore, that abrogate the human rights of people, could not take precedence over the laws of God. No human court or legislative body could establish laws that ran roughshod over human rights could rightfully expect to be respected and in fact were dangerous to the nation. They must be rejected. "They are a flagrant violation of the rights of man;" Bourne declared, "they are an insult to common sense; and they are an indelible disgrace to our republic and the world. Away with them!"48

Soon the incongruences between Bourne's faith and the slavery that he beheld began to emerge. Increasingly he began to feel that these practices were not in line with the precepts of the Bible and the gospel of Jesus Christ. He saw correlations between the oppressions he found were described and denounced in the Bible. Bourne began to speak on the issues with his congregation, not only retelling how stories of oppression in the Bible were condemned, be applied the lessons to what he witnessed in Rockingham County. He pointed out the issues he saw with a provocative style that challenged his parishioners, who heretofore were unaccustomed to hearing their peculiar institution so directly maligned. The notion that the good book and its peculiar institution were incongruent and irreconcilable was obnoxious to the residents of Rockingham County. Despite their irritation, Bourne increased the intensity of his preaching until things came to a head when he applied the eighth commandment against stealing to slave holding.

\footnotetext{
${ }^{48}$ Ibid, 119.
} 
Slaveholders in Rockingham increasingly wanted him gone. Despite their opposition, Bourne resolved to stay in town to testify against the slave system he witnessed in Rockingham. So determined was he to go public against American slavery right there in Virginia that he learned typesetting and self-published The Book and Slavery Irreconcilable in $1812 .^{49}$

The thesis of Bourne's book was that the Bible opposed American slavery. He saw it to be his task to challenge Virginians, and Americans at large, to repent of their sins against God and Africans. The front page of the The Book and Slavery Irreconcilable began with the admonition that God had until now "winked" at the sin of slavery, "but now commandeth all men, every where, to repent." ${ }^{, 50}$ Invoking Jesus, Bourne declared that the "Spirit of the Lord! Who didst anoint Jesus of Nazareth, to preach deliverance to the captives: O, illumine! O, Regenerate! Blind, corrupt oppressors!" 51

It was in this first book that he to put to paper his conviction that there must be an immediate abolition of slavery without compensation to slave holders and mocked the idea of taking a "moderate" stance against slavery as "absurd." 52 He interrogated slaveholding Americans with a central question: How could Americans regard a man "who stealeth his brother, makes merchandise of him, sells him or if he be found in his

\footnotetext{
${ }^{49}$ Theodore Bourne, "Rev. George Bourne," 74.

${ }^{50}$ George Bourne, The book and slavery irreconcilable: with animadversions upon Dr. Smith's philosophy, Philadelphia, 1816, Slavery and Anti-Slavery, Gale, Florida International University, accessed 8 July, 2016, front page. Note: Though the publishing date for this book is 1816, Theodore, Bourne's son, writes that the first edition of this text was first self-published by his father while in Virginia. This is a plausible explanation as it was ready in January of 1816, only one month upon arriving in Pennsylvania after being forced to leave in December of 1815.

${ }^{51}$ Ibid, 3.

${ }^{52}$ Ibid, 4.
} 
hand, whom the Word of God proclaims to be a Thief, is an honest man and a Christian[?]"53 Bourne maintained that as far as the Bible was concerned, "Slavery is condemned." Bourne believed that American slavery must attract the strongest rebuke possible. "Among the various modes by which they are displayed, the detention of men in bondage indefinite, should receive unmitigated execration..." ${ }^{54}$ The purpose, therefore, of his "investigation" was to test "the uprightness of those pretences which Oppressors offer, why they should be considered Christians. ${ }^{" 55}$ Bourne maintained that the American slavery system was beyond cure and thoroughly corrupt and must be immediately abolished. "The system is so entirely corrupt," Bourne declared, "that it admits no cure, by a total and immediate, abolition. For a gradual emancipation is a virtual recognition of the right, and establishes the rectitude of the practice. If it be just for one moment, it is hallowed for ever; and if it be inequitable, not a day should it be tolerated." 56

Bourne's central argument against slavery was that it was theft. His premise was based on the scripture in Exodus 2:16 which stated that "He that stealeth a man, and selleth him, or if he be found in his hand, he shall surely be put to death." Bourne maintained that there was "no real distinction between him, who steals the woman from her husband. [sic] The child from its parent, or the whole family, on the eastern or the western shores of the Atlantic, whether for exportation or domestic vassalage." Bourne believed that the stealing of humans from Africa was the same as Israelites kidnapping

\footnotetext{
${ }^{53} \mathrm{Ibid}, 7$.

${ }^{54}$ Ibid, 16.

${ }^{55}$ Ibid, 7.

${ }^{56} \mathrm{Ibid}, 154$.
} 
others within their community to be sold into slavery. Bourne cried that everyone involved in the process of kidnapping, selling, buying and holding in bondage to be complicit with a dehumanizing system. 'By this law," Bourne argued, "every manstealer, and every receiver of the stolen person, lost his life: whether the latter stole the man himself, or gave money to a Slave-Captain or Negro-Dealer to steal for him. All kidnapping and slave-dealing are prohibited, whether practiced by individuals or the state." ${ }^{\prime 57}$ As far Bourne could see in the Bible, those who participated in the system of slavery that commodified and merchandized Africans were guilty as such a high crime that they deserved the death penalty. He quoted scripture to back up his argument. "If a man be found stealing any of his brethren of the children of Israel," Bourne declared, "and maketh merchandize of him, or selleth him, then that THIEF shall die.' Deuteronomy 24:7."58

Bourne also used the Bible to condemn the concomitant system fugitive slave laws that prevented enslaved Africans from self-emancipation. He cited four examples of scriptures that spoke against the turning over a fugitive to their masters. The first example Bourne used was the scripture Deuteronomy 23:15-16. "Thou shalt not deliver unto his master," Bourne quoted "the servant who is escaped from his master unto thee: He shall dwell with thee, even among you, in a place which he shall choose, in one of thy gates where it liketh him best: thou shalt not oppress him. ${ }^{, 59}$ In a second citation, Bourne used an occasion in the scriptures that seems to condemn fugitive slave laws. Retelling a story

\footnotetext{
${ }^{57}$ Ibid, 25.

${ }^{58}$ Ibid, 26.

${ }^{59}$ Ibid.
} 
detailed in 1 Samuel 30:10-16 of David and an Egyptian servant, Bourne recalled that the Egyptian servant made David promise to "swear unto me by God, that thou wilt neither kill me, nor deliver me unto the hands of my master" in exchange for his leading David and his men to the location where his master was hiding. ${ }^{60}$ The third example is listed in Isaiah 16:3 which states, "Take counsel, execute judgment; make thy shadow as the night in the midst of the noon-day: hid the outcasts, betray not him who wandereth." ${ }^{61}$ And finally, Bourne used Obadiah 1:15 to assert that the prophet Obadiah abjured those who "stood in the crossway to cut off those who did escape" and "delivered up [those] who did remain in the day of distress. ${ }^{{ }^{62}}$ Bourne used these scriptures to proclaim that "slaveholding is an abomination in the sight of God" because he "justifies the slave in absconding from his Tyrant, and enjoins upon every man to facilitate his escape, and to secure his freedom." ${ }^{63}$ Bourne thus linked American slavery to the system of hunting and handing over fugitive slaves to their masters.

Bourne, like previous abolitionists, predicted divine retribution for a system that held, sold, hunted, and handed slaves over to their masters - and he used scriptures to make his argument. "The prophesies," Bourne proclaimed, "are filled with divine denunciations against Judah and Israel, for their oppression, fraud, rapine, cruelty, and the varied enormities which originated in their covetousness; and Tyre was destroyed for

\footnotetext{
${ }^{60}$ Ibid.

${ }^{61}$ Ibid.

${ }^{62}$ Ibid.

${ }^{63}$ Ibid.
} 
having traded the persons of men." ${ }^{64}$ Bourne also cited the Apostle Paul's denunciation of "slave-holders," however, by citing Romans 1:30 this seems to be a typo. ${ }^{65}$ Bourne did, however, use Revelation 18:13 in which the Apostle John wrote that "The Lord God who judgeth her, will effuse his wrath upon Babylon, because she makes merchandize of Slaves, the bodies, and souls of men." ${ }^{96}$ Bourne equated American slavery with a system that stole, kidnapped, sold, held, hunted and handed over humans to their masters. In a word, humans were commodified and held against their will in this system. For Bourne, the Bible stood against it all and prescribed God condemnation and retribution for those who practiced and benefitted from it.

On the basis of Bourne's conviction that the Bible stood athwart to American slavery, he began to question the Methodist and Presbyterian denominations. Bourne maintained that the Bible condemned "the buying and selling of men, women, or children, with an intention to enslave them. ${ }^{.67} \mathrm{He}$ also cited the Methodist discipline's assertion that those who wish to place membership should "'desire to flee from the wrath to come, and to be saved from their sins"” as a condition of entrance into the denomination. Bourne, however, reasoned that if the Bible establishes that such a system of slavery as he described was roundly condemned, how could "Methodist Christians engage in this evil" and still be in good standing as members? ${ }^{68}$ In other words, for

\footnotetext{
${ }^{64} \mathrm{Ibid}, 28$, the scripture reference is Ezekiel 27:13.

${ }^{65}$ Paul denounces slave traders in 1 Timothy 1:10.

${ }^{66}$ Bourne, The Book and Slavery, 30.

${ }^{67}$ Ibid, 31 .

${ }^{68}$ Ibid.
} 
Bourne, American slavery as a criminal system, had no place in the church. The "system of slavery, Bourne decried, "is justly held unwarrantable; because, by it, persons are involved in the enormous crime of manstealing." ${ }^{69}$ Bourne therefore pushed for the idea that American slavery, as a criminal system rife with kidnapping and human theft, was grounds for expulsion from the church since "slave holding is man-stealing." ${ }^{.70}$ It was a crime against one's neighbor just as sure as stealing their property, sheep, or money. ${ }^{71}$ The theft was against families as children were stolen from parents and wives were pilfered from husbands. It was an "outrage on the sacred rights of liberty, of justice and of humanity." It made no difference if the theft was committed in Guinea or Virginia, theft was theft and such a crime was against the "law of God" as written in Exodus $21: 16 .^{72}$

Bourne was astounded that Americans, who were ostensibly influenced by the Bible and stood for liberty, would tolerate oppression in their nation. "What an intolerable evil!" Bourne lamented, "How incredible! that men in the Land of Liberty and filling official stations under the authority of the Book, require to be instructed, that to steal, buy and sell men, women and children is contrary to the Gospel." What is more, the poor treatment of a whole race of people even as the nation was supposedly based on Christian principles. Bourne felt that Americans should know better. Bourne listed the litany of maltreatment of enslaved Africans in his indictment of Americans. He declared

\footnotetext{
${ }^{69}$ Ibid, 32.

${ }^{70}$ Ibid.

${ }^{71}$ Ibid.

${ }^{72}$ Ibid, 33-34.
} 
that Americans must know that "to defraud the labourer of his hire, to rob the mind of necessary light and the heart of indispensable melioration, and to doom the human race to labour lasting their existence, without food, raiment, a habitation, and other necessaries to support life and recruit nature exhausted by endless fatigue" were actions that were "totally incompatible with the precept, do justly, love mercy, and walk humbly with God" These actions toward enslaved Africans, Bourne charged, were an "odious and most criminal violation of the eighth commandment," and those involved, "should cease every pretension to Christianity." 73

Bourne argued American slavery was a violation of several of the Ten Commandments and other facets of the Mosaic law. As for the commandment: Thou shalt not kill, Bourne accused that "slavery is the most benign form [of] slow-paced murder." Regarding the commandment to not bear false witness against thy neighbor, Bourne asserted that "no man can possess a slave, until he has virtually sworn, that men, women, and children are brutes." Of the commandment prohibiting the coveting of anything belonging to one's neighbor (i.e. house, wife, servant, ox, etc.) Bourne argued that "the Slave-holder not only desires, but actually steals them, with his neighbor also; thus consummating his guilt by the most daring rebellion and transcendent depravity." Other laws that American slavery trampled was the decree which stated, "Thou shalt not defraud thy neighbor, nor rob him." Bourne referenced this scripture to assert that "this unceasing cheating and robbery commence when the child first breathes and ends only at his death." In essence, enslaved Africans were defrauded of their freedoms and their very lives. Regarding the proper treatment of the poor Bourne quoted the scripture "Thou shalt

\footnotetext{
${ }^{73}$ Ibid, 69-70.
} 
not oppress him who is poor and needy, lest he cry against thee unto the Lord, and it be a sin unto thee; is stealing a sin, and giving him no necessaries, oppression?" Regarding the treatment of the immigrant, who enslaved Africans were in the U.S., Bourne proclaimed "Thou shalt not neither vex a stranger, nor oppress him" and asserted American slaveholders "kidnap the Stranger; to chain him in endless vexations and calamities." In regards to the unrequited toil of enslaved Africans, Bourne appealed to the scripture in James. "Behold," Bourne cried, "the hire of the labourers who have reaped down your fields, which is of you kept back of fraud, crieth: and the cries of them who have reaped are entered into the ears of the Lord of the Sabaoth..." Bourne continued by accusing that "the Slave-Tyrant's reapers are never paid." Insofar as the widows and orphans Bourne charged that "Ye shall not afflict any widow or fatherless," but at the hands of American slaveholders, Bourne accused, "the incessantly afflictive experience of coloured females and orphans, neither eloquence can display, nor imagination comprehend."74

Because of such widespread violations of God's laws, Bourne prophesied that American slaveholders should expect that God would respond with retribution. Channeling the words of the prophet Malachi, Bourne proclaimed God's words:

I will come near to you to judgment; and I will be a swift witness against falseswearers, and against those who oppress the hireling in his wages, the widow, and the fatherless, and who turn aside the stranger from his right, and fear not me, saith the Lord of Hosts. ${ }^{75}$

\footnotetext{
${ }^{74}$ Ibid, 81; Exodus 22:22.

${ }^{75}$ Ibid, 82; Malachi 3:5.
} 
The list of scriptures that Bourne referenced to argue against American slavery brought him to summarize that this system stood condemned by God. "Slavery is adverse," Bourne asserted, "to all the principles and requisitions which the Scriptures reveal." It was not merely because American slavery stood alone. Bourne maintained that American slavery was intimately tied to the slave trade. He charged that the "purchase, or sale, or vassalage, or involuntary hire of men or women" created a systematic denial of human "rights which were granted by the God of nature." Such a dehumanizing system, Bourne wrote, "nullifies the evangelic law of love and equity, and is unequivocally denounced by the Holy Bible, as the highest degree of criminality connected with this temporal state of probation." ${ }^{76}$

While Bourne condemned American slavery, he distinguished it from the servitude of the Bible. "Servitude in Abraham's family," Bourne explained, "was very different from the degradation of our colored population." He provided examples of slaves in the Bible and how they held more rights than the slaves in the U.S. Bourne used an example from Abraham. "Eliezer of Damascas," Bourne explained, "was the Patriarch's steward, and his servants, had he died childless, would have been his heirs." 77 The notion that an American slave or servant could conceivably become an heir to all that his master owned was preposterous in American slavery. Bourne pointed out that Abraham and his slaves worshipped together and were "included in the covenant made with him, by circumcision." ${ }^{\text {78 }}$ In other words, by the rite of circumcision, Abraham's

\footnotetext{
${ }^{76}$ Ibid, 89.

${ }^{77}$ Ibid, 122; Genesis 15:3.

${ }^{78}$ Ibid.
} 
slaves were ushered into the communal relationship with God that Abraham enjoyed. Abraham thus welcomed his slaves as family members with "paternal benevolence." While Bourne's reference to "paternal benevolence" smacks of the southern defense of their peculiar institution of paternalism; Bourne makes a distinction when he avers that Abraham displayed true "paternal benevolence" when he was willing to designate a servant as his heir.

As for the New Testament writers and slavery, Bourne denied that either Jesus Christ, the Apostles or the New Testament supported American slavery. Jesus, for one, "who had not where to lay his head" had nothing in common with the wealthy slaveholders. Secondly, the Apostles, according to Bourne, "were not human flesh weighers." Bourne believed that those who used the New Testament to defend American slavery could no more "join heaven and hell" than defend such an untenable position. Bourne maintained that "joining heaven and hell" would likewise involve joining "vice and virtue, equity and injustice, kindness and cruelty, oppression and benevolence, thieving and probity, infidelity and religion," thus making them all "identical." If such could be done, then American slavery could be justified by the Bible. Instead, Bourne argued that the principal New Testament teaching stood in opposition to American slavery. Repeating the words of Christ, Bourne taught that "ALL things whatsoever ye would that men should do unto you, do ye even so unto them: for this is the LAW and the Prophets." Bourne wondered how anyone with sound morals could deduce from that scripture that the Bible supported American slavery. "If any man," Bourne exclaimed, "can deduce the injustice, the barbarity, and the oppressions of man-stealing, from this fundamental rule of social reciprocity, his moral alembic must combine properties vastly 
different from any extractor yet discovered." Indeed, Bourne believed the New Testament roundly condemned the key factors that drove the industry that was American slavery and promoted those values that called for the amelioration of such a system. "These citations," Bourne declared, "either immediately reprobate covetousness, extortion, and tyranny, or they inculcate justice, philanthropy, and mercy; and it is absolutely impossible to conjoin these directions and examples with the bondage of men, or to explain them in any manner, by which Slave-holders are not most indignantly and awfully censured."${ }^{79}$

Bourne found himself in an absurd world in which slaveholders savagely treated the enslaved and yet claimed to be Christians. He wondered aloud how slave owners could claim to obey the Bible or properly worship God while holding humans in bondage. "Genuine Christian prayer and slavery cannot be conjoined," Bourne declared. "What can be more shockingly absurd," Bourne asked, "than the petition; 'forgive us our trespasses, as we forgive them who trespass against us!' uttered by a slave-driver in the presence of his slaves, whom he robs, starves, and scourges; and whose tears, tortures, and blood daily cry to Heaven for retribution?" ${ }^{\prime 80}$ Furthermore, Bourne demanded from church leaders what correlation could be drawn between slavery's "incestuous defilements, its sleepless barbarity, its daring impiety, and its desolating curse" with Jesus a "friend of sinners, who came to "preach the gospel to the poor, to heal the brokenhearted, to preach deliverance to the captive, to set at liberty them who are bruised, and to

\footnotetext{
${ }^{79}$ Ibid, 131-132.

${ }^{80} \mathrm{Ibid}, 132$.
} 
seek and to save that which was lost." ${ }^{81}$ By invoking Jesus Christ, Bourne sought to paint a contrast with American slavery with Christ's teachings.

Notwithstanding Christ's teachings, churches in the South abided the dehumanizing treatment of the enslaved. Bourne could only conjecture that American slavery was tolerated in the church because of the money that flowed into its coffers from wealthy slave-holding congregants. Bourne lamented that people must "remember the large donations which are contributed by the southern churches to benevolent institutions, as a proof of their philanthropy and religion." Further, Bourne lamented that the churches willingly received these gifts purportedly “avowed holy purposes.” Bourne believed it was "deplorable" that the churches allowed themselves to be so influenced by the large contribution from wealthy slave owners. Bourne called such a corrupt system an "unhallowed combination in our country, which so influences our northern Christian citizens, that they will accept the spoils of kidnappers, as suitable voting offerings to the treasury of brotherly love, or Christian zeal [...]"82 Bourne condemned this corruption and quoted the Prophet Isaiah by proclaiming that such contributions were an “abomination" and thus rejected by God. ${ }^{83}$

In the startling reality that was American slavery, men who stole the souls of men and dehumanized them held places of respect within the southern Christian churches. The systematic theft of human beings, according to Bourne, was the fundamental problem

\footnotetext{
${ }^{81}$ Ibid, 132-133.

${ }^{82}$ Ibid, 140.

${ }^{83} \mathrm{Ibid}$, Isaiah 66:3ff quoted.
} 
with American slavery and those who held slaves against their will were therefore "manstealers." As such, every "manstealer" must be excommunicated from the church if this system were to be abolished. "But as a man-stealer is the very highest criminal in the judgment of God," Bourne cried, "and all rational uncorrupted men, he cannot be a Christian, and therefore, it is an insult to the Lord Jesus Christ, the head of the church, to record the most notorious criminal, as an acceptable member of the "household of faith." 84 "[Manstealing] is both the root and offspring of modern American slavery," Bourne declared. He also lamented that the churches did not eradicate the problem of American slavery immediately after the nation gained its independence. Their failure to do so exposed the nation to future divine retribution. "Had the various Christian denominations in the United States, immediately after the close of the revolutionary war, honestly promulgated evangelical truth," Bourne lamented, "and faithfully preserved the order of the Lord's house upon this momentous subject, no slave would now exist, to implore the curse of God in his retributive vengeance, upon our slave-dealing republic." 85

The theology that was employed by southern churches to mollify the enslaved appeared void of any true meaning to Bourne. Instead of showing slaves the way to true spiritual freedom, the leaders of American slavery had created an absurd world that made no sense. To make them docile and content with their circumstances, Bourne accused, Christian leaders taught the slaves that if they be "turbulent, or lazy, or wish to become free; and above all, if they attempt to run away then, according to [Jesus'] account, from

\footnotetext{
${ }^{84}$ Ibid, 147-148.

${ }^{85}$ Ibid, 148.
} 
hell at last they cannot escape" and instead incur "the curse of God." ${ }^{86}$ Further, slaves were taught to adhere to a "system of theology" that to "obey his ruffian kidnapper is to please God; to take away his own chicken to satisfy his hunger, incurs his divine wrath; to endeavor to become a Christian freeman is only to fall into the devil's clutches; a desire to learn to read, that he may search the scriptures, is rebellion against God." Bourne believed that the slave had as his "birthright privilege" to freely "love and serve God with all his heart, and mind, and strength, and soul" but to do so in the system that was American slavery he was made to feel that to do so as a free man was "a sin." To desire to live as such a free man only incurred the slave "pitiless severity and harsher privations" the likes of which included "scourging or maiming" and even the white man's threat of "eternal condemnation." 87 Bourne thus was galled that white Christian leaders dared add insult to injury by insisting that enslaved Africans not only tolerate their bodies being sold, but that they allow their minds, souls and spirits be chained as well. Bourne dubbed such false teaching "pseudo-religious instruction." 88

To a preacher, to whom every soul was valuable and should be saved and enlightened about the ways of Christ, Bourne was appalled to find that the enslaved were barred from access to religious instruction. Bourne held slave-holding preachers responsible. "Preachers publicly," Bourne lamented, "and as readily exchange men for horses, and women for sheep, or sell and buy and traffic boys and girls, as any other class

\footnotetext{
${ }^{86} \mathrm{Ibid}, 175$.

${ }^{87}$ Ibid, 175.

${ }^{88}$ Ibid.
} 
of men-stealers!" ${ }^{89}$ Bourne believed that their being barred from education, further kept enslaved persons in an animalized station in society. "In the Negro quarter belonging to preachers," Bourne charged, "the slaves live with no more religious instruction, equally destitute of food and clothing, and labour as incessantly, and are scourged as often and as barbarously, as on the neighboring farms and plantations, of which the domestic despots are avowed sons of Belial. ${ }^{" 90}$ For Bourne, it was one thing for those who claimed to follow the benevolent Christ to act this way and quite another for those who made no such claims. While the latter might be expected to act this way toward their enslaved, the former had no excuse. And, Bourne believed they would be held accountable for the role their hypocrisy had played in establishing American slavery. "You preachers," Bourne charged, "are the existing cause of the wickedness and curse of slavery in America; and as long as we have myriads of men-stealing ministers and professors, so long will all our churches be justly chargeable with being one half hypocrites, and the other half confederates." ${ }^{\prime 91}$ In other words, the nation could not rid itself of the stain of American slavery if the churches continued as a haven for slaveholders.

On the basis of Bourne's conviction that both the Old and New Testaments in the Bible condemned American slavery, he challenged church leaders to evaluate themselves in the light of scripture. "You are now," Bourne proclaimed, "all called to repentancePreachers, Elders, Exhorters, Deacons, Leaders, and Professors: how can you deny your own faith?" Bourne wondered how church leaders could tolerate slavery and still profess

\footnotetext{
${ }^{89} \mathrm{Ibid}, 177$.

${ }^{90}$ Ibid.

${ }^{91}$ Ibid, 180.
} 
to be followers of Jesus Christ even while they acknowledged its injustice. "[H]ow can you profess that slavery is the highest crime against God and Man," Bourne asked, "and practice it? how [sic] can you promulgate that a Slave-holder is the most guilty Thief, and notwithstanding yourselves continue to steal, and affirm that you are sanctified?" Bourne called it a "contradiction" and a "Satanic delusion" to mix "religion and slavery." Those who sought to harmonize the two were "deceived." He cautioned Christians against believing the two were compatible. "Be not deceived," Bourne warned, "to affirm that a Slave-holder is a genuine disciple of Jesus Christ, is most intelligible contradiction." He also questioned the logic of claiming to be a "brother" of Jesus "who went about doing good" and yet "steal, enslave, torment, starve, and scourge a man because his skin is of a different tinge!" Bourne could only conclude that "such Christianity is the Devil's manufacture to delude souls to the regions of wo." [sic $]^{92}$

If Bourne's challenges to his congregation were anything like his writings he was sure to rile those congregants who owned slaves. And he did. He began to bar slaveholders from his congregation drawing even more opposition to his ideas in Rockingham. Persecution became intense in the community at-large. Apart from the opposition he received from his congregation, a mob seeking to destroy his home and drag him out to punish him paid a visit to his home. After ransacking the first floor the mob had plans to go upstairs and continue their rampage. They were only dissuaded upon learning that Bourne's wife was upstairs ill and alone. Incidents like this one, and other threats, often left his wife wondering when she would receive word of her husband's assassination. Despite threats like these upon his life, he carried through on his stance

${ }^{92}$ Ibid, 137. 
against slaveholders and made a motion to the Presbyterian General Assembly to bar slaveholders according to the Presbyterian Church Constitution.

Bourne was not content to oppose American slavery at his congregation or even in Virginia. In 1815 he set his sights on barring slaveholders from the Presbyterian denomination as well. That year he made a motion to the General Assembly in Philadelphia to bar slaveholders from the Presbyterian denomination per the Presbyterian Constitution's prohibition of menstealing. His local actions against slaveholders had received the support of some of his congregants. But if his local efforts earned him opposition, his motion in Philadelphia gained him even more fierce enemies. Bourne went before the General Assembly and issued accusations against four leaders within the Presbyterian Church in Virginia who had treated their slaves in brutal fashion. He did so, however, without naming them. Despite his refusal to name them, however, he managed to impugn a whole class of Virginia slaveholders in Rockingham since the allegations were not specific enough to acquit those not named. The General Assembly, not wishing to alienate the powerful slaveholding minority, did little more than issue a slight admonition to treat their slaves humanely and provide education to prepare them for their eventual freedom. Bourne meanwhile gained more enemies as he managed to insult a whole class of pastors, teachers and elders who owned slaves by calling them "manstealers" and "thieves." Needless to say, Bourne condemned the non-action of the General Assembly. Even some of his friends, who up to then had supported them, were caught in the crossfire and forced to turn their backs on them. In the meantime, because he had publicly maligned slaveholders, who were generally held in high regard, to the 
General Assembly, he was forced to leave Rockingham, Virginia. He did so in December, $1815 .{ }^{93}$

A contingent of these maligned Virginia leaders made it their business to not only remove Bourne, but also remove the language from the Presbyterian Constitution that he invoked to motion for their removal. They zeroed in on Question 142 of the Constitution of the Church which named manstealing as a violation of the Eighth Commandment against stealing. By 186 they had managed to remove the question from the Constitution and secure Bourne's ouster as a preacher within the Presbyterian Church. But if they thought they had heard the end of Bourne and his argument that manstealing was a violation of the Eighth Commandment against stealing, they were wrong on both accounts. His case came before the General Assembly twice more with the General Assembly equivocating on the issue until finally taking the slaveholders' side by refusing to eject them from the Church. Bourne did leave the state, but regained his license to preach in the Presbyterian Church, albeit in a northern Presbyterian Church in Germantown, Pennsylvania. Ultimately, however, it was not the last they would hear of George Bourne and his brand of immediatist antislavery theology. ${ }^{94}$

\footnotetext{
${ }^{93}$ Dumond, Bourne: The Book \& Slavery, 22-26, 29-34, 49.

${ }^{94}$ Ibid, 51-52, 58-63.
} 


\section{CHAPTER V}

\section{The African American Voice, the Bible and American Slavery}

David Walker had seen enough. After a tour of slave states and viewing the depths of the wretchedness of his brethren in the slave states, he decided to write an appeal. His appeal contained his vision of God. It was a vision of God who ruled the armies of heaven and held sway over the inhabitants of the earth. Walker's God was holy, just and untarnished by the corruptions of man. His eyes always saw the condition of the oppressed. He saw their tears and heard the cries and felt their groans. God moved in history on behalf of the oppressed and was now ready to act. God was ready to stop the avaricious progress of the oppressors and set in motion their destruction. This destruction would be God's doing, not necessarily by the "effect" of the oppressed. And in a flash of clear forward vision that his pen could scarcely keep up with, Walker predicted the "destruction" of the oppressors of his wretched brethren in the U.S. "The Lord our God," Walker declared, "will bring other destructions upon [the oppressors] — for not unfrequently will he cause them to rise up one against another, to be split and divided, and to oppress each other, and sometimes to open hostilities with sword in hand." In his prophetic assertion, David Walker gave a glimpse of the future civil strife in the U.S. that he believed God would provoke on behalf of the oppressed. Doing so, Walker became the first abolitionist to publicly predict the internecine nature of divine retribution for American slavery.

Walker's public prediction was not the first time an African American publicly warned of divine retribution for American slavery. Caesar Sarter, a former slave, wrote an essay that was published on August 17, 1774 in Massachusetts which called for the 
immediate emancipation for slaves lest Americans suffer "the miserable end of Pharaoh." Sarter couched his appeal to the people of Massachusetts in the revolutionary context in which they found themselves. He called the slave trade an "iniquitous business" and a "great evil" and urged the citizens of Massachusetts to "pity and relieve the poor, distressed, enslaved Africans" even as they sought their freedom from Great Britain. $\mathrm{He}$ did not purport to answer every proslavery argument, but appealed to their Christian ethos and their respect for the Golden Rule. "I shall not," Sarter pleaded, "pretend a refutation of the arguments, generally brought in support of it; but request you, to let that excellent rule given by our Saviour, to do to others, as you would, that they should do to you, have its due weight with you." He attempted to humanize the plight of the slave by asking his readers to put themselves in the places of the enslaved and suppose they were the taken away as a "husband from the dear wife" or the "wife from the affectionate husband" or even the "children from the fond parents." Sarter even invoked the story of Exodus in which God heard "the groans of the oppressed and will sooner or later, avenge them of their oppressors!" and quoted the passage in Exodus 20:16 proscribing kidnapping: "And he that stealeth a man, and selleth him, or if he be found in his hand, he shall surely be put to death.” Others followed where Sarter left off. ${ }^{1}$ David Walker and Maria Stewart were the key African American voices that used the Bible to offer a sustained critique of American slavery and argue for its immediate abolition lest the nation suffer divine retribution.

\footnotetext{
${ }^{1}$ Caesar Sarter, "Address to Those who are Advocates for Holding the Africans in Slavery," in Carol Sue Humphrey, Voices of revolutionary America: contemporary accounts of daily life (Santa Barbara, California: Greenwood, 2011), 213-216.
} 
Walker's Appeal was the apex of black rhetorical resistance to the advent of colonization schemes, racist ideology and American slavery. Preludes to colonization schemes began with altruistic motives and with cooperation from African Americans. As northern states were emancipating their slaves in the late $18^{\text {th }}$ century, churches were sending African Americans as missionaries to Africa. Samuel Hopkins and Ezra Stiles raised money to send to Africa John Quamine and Bristol Yamma, two willing Congregationalist African American missionaries. British abolitionist Granville Sharp also helped establish an African settlement of freed slaves. Other African Americans, like James Forten, were eager to develop emigration programs to Africa or Haiti in search of settlement opportunities in places where African Americans would ostensibly not have to face racial discrimination. As the $19^{\text {th }}$ century came around more African Americans like Paul Cuffe and Prince Saunders saw emigration to encourage slave owners to emancipate their slaves with the assurance they would not settle locally. These efforts ended, however, with mixed results and only strengthened African American resolve to improve their conditions in the U.S. rather than emigrate abroad. ${ }^{2}$

Due to a confluence of trends and events, however, emigrationist schemes slowly took a sinister and paternalistic turn as white America took an interest in emigration to diffuse and colonize free African Americans. The belief was that free African American would not remain local to influence enslaved Africans. African Americans soon found themselves resisting schemes they initially eagerly sought. White Americans created opportunities to diffuse African Americans. The Louisiana Purchase of 1803 made

\footnotetext{
${ }^{2}$ Christopher Cameron, To plead our own cause: African Americans in Massachusetts and the making of the antislavery movement (Kent, Ohio: Kent State University Press, 2014), 100-113.
} 
828,000 square miles of land available for the westward spread of American slavery. This major acquisition coincided with the domestic slave trade that was hitting its stride. States in the Upper South like Virginia, Maryland and Delaware sold their surplus of slaves to the lower South as a part of the trade's forced migration that fueled the lucrative cotton plantations. The territories were not just viewed as opportunity for the expansion of American slavery, it was considered as a source of funds to promote the colonization of free African Americans back to Africa. The American Colonization Society (ACS) had already been established in 1816, with the express purpose of sending free blacks to Africa and not just as missionaries. It was therefore no great surprise that Henry Meigs, a New York Congressman, introduced a resolution in 1820 that "a committee be appointed" to explore the possibility for "devoting the public lands as a fund for the purpose of" destroying the slave trade, "the emancipation of the slaves in the United States; and "colonizing them in such way as shall be conducive to their comfort and happiness in Africa, their mother country." James Madison and James Monroe, both Virginia planters, were arguably on board with this resolution. ${ }^{3}$

African Americans obviously had no objections with being freed. They did, however, have a problem with any notions of being repatriated from the land of their birth or in which they had grown up. The only rationalization for colonization schemes like those of Henry Meigs were that they were based on race. African Americans, it was thought, would be of more "comfort and happiness in Africa, their mother country."

\footnotetext{
${ }^{3}$ Baptist, The Half has Never been told, 47; Tadman, Speculators and Slaves, 12; quote from Annals on Congress, 16th Cong., 1st sess., pp. 1113-14 quoted in Robert P. Forbes, "The Missouri Controversy and Sectionalism" in Congress and the Emergence of Sectionalism: From the Missouri Compromise to the Age of Jackson, eds. Paul Finkelman and Donald R. Kennon (Athens, OH: Ohio University Press, 2008), 87-89.
} 
Blacks opposed any such notions, never having been consulted and understanding that such plans were poorly disguised schemes to rid America of black people. African Americans considered themselves as Americans, even if they did not enjoy status as citizens. They envisioned and nurtured a collective desire to live as American citizens. African Americans took to the streets in Philadelphia in public protest in 1817 and again in 1819 proclaiming that "the plan of colonizing was not asked for by us; nor will it be required, in our present or future condition, as long as we shall be permitted to share the protection of the excellent laws and just government which we now enjoy." Similar sentiments were expressed in other major northern cities as blacks coalesced in opposition to colonization. White Americans, however, were not convinced that African Americans were able to be fellow citizens. Members of the ACS averred that blacks could not survive in white America because of its pervasive racism. Furthermore, as Meigs' resolution states, they believed that Africans were more biologically suitable to the environs of Africa, their "mother country." 4

Henry Meigs's resolution, meanwhile, was submitted at the height of the Missouri Crisis that had a domino effect on the south and particularly Charleston, South Carolina where David Walker resided. Americans barely had enough time to enjoy the so called "Era of Good Feelings" as immediately after the victory of the War of 1812 New York Rep. James Tallmadge submitted an explosive resolution, "[t]hat the introduction of slavery or involuntary servitude be prohibited" in Missouri if it would become a state." The resolution abruptly ended any good feelings between the North and the South and

\footnotetext{
${ }^{4}$ Petition presented by Philadelphia blacks "To the Humane and Benevolent Inhabitants of the City and County of Philadelphia ," cited Mia Bay in The White Image in the Black Mind: African-American Ideas about White People, 1830-1925 (New York: Oxford University Press, 2000), 22-24.
} 
plunged the nation into a two-year bitter dispute over slavery's advancement into the territories. Up to this point, the South had enjoyed unfettered advancement of slavery into the territories. Since the ratification of the U.S. Constitution, four slave states, Kentucky, Tennessee, Louisiana and Mississippi had been admitted with nary a peep and one, Alabama, was in line to be admitted that year. The South had been rolling right along. Now, for the first time since the ratification of the Constitution, the South was forced to justify on a national level why it should be allowed to admit yet another slave state into the Union. The South began to suddenly feel under siege as antislavery opponents sprang up even among their midst in Congress. Besides Tallmadge and later Meigs, Senator Rufus King of New York gave an impassioned anti-slavery speech that reverberated deep into the South, as far as Charleston, South Carolina. Denmark Vesey, in Charleston, reportedly heard of the blistering speech and it served as fuel for his fire for rebellion. ${ }^{5}$

If the attacks on slavery in Congress did anything else, it provoked the South to ramp up their proslavery propaganda apparatus. Up to then, the South did not feel the need to defend their institution, but now, with Tallmadge's proposal, the South now saw the need to vehemently defend their peculiar institution. Proslavery arguments using the Bible were relatively quiet from the ratification of the Constitution through the Missouri Crisis as the South was given free rein to expand American slavery westward. The establishment of constitutional safeguards in the form of 3 clauses protecting the rights of human property, Eli Whitney's invention of the cotton gin facilitated cotton production,

\footnotetext{
${ }^{5}$ David Brion Davis, Challenging the Boundaries of Slavery, Annals, $15^{\text {th }}$ Cong., 2d sess., p. 1170 cited in Forbes, "The Missouri Controversy," 75; Ibid., 91.
} 
the nation was expanding west in search of land for cotton production, slave states were being added west of Georgia and cotton production was booming. Slavery in the South was on the move without powerful challenge. The first wave of abolitionist agitation of the late $18^{\text {th }}$ century was unable to effectively do much more than effect the establishment of gradual abolitionist laws in the North and cap the international slave trade to end by 1808. By then, there was a seamless transition from the international trade to the domestic slave trade for while the Constitution allowed for the sunset of the international, it said nothing about the slave trade and certainly did not make the domestic slave illegal. In 1819 things changed as a powerful challenge emerged on a national level with Tallmadge's motion. Now Southerners were on the defensive and forced to justify their institution. What is especially significant about the Missouri debates is that they forced proslavery apologists to develop a systematic biblical defense of slavery. Proslavery apologists like Dr. Thomas Cooper of South Carolina College published pamphlets arguing that slavery was never forbidden by the Bible, that slavery had always existed and that slaves in the South were well cared for compared to how the poor in other countries fared. These basic arguments were repeated in defense of slavery during heated congressional debates and challenges from those of the Colonization society. These debates raged throughout the 1820 s and grated on African Americans. ${ }^{6}$

African Americans were practically unanimous in their vehement opposition to the ACS. Samuel Cornish, minister for the Black Presbyterian Church of New York, rose as a key voice of black dissent and created the first black publication, Freedom's Journal,

\footnotetext{
${ }^{6}$ William Sumner Jenkins, Pro-slavery thought in the Old South (Gloucester, Mass: P. Smith, 1960), 48,
} 66, 73. 
to voice opposition to the ACS. Writing years later, he recalled that the black community protested the ACS from day one first in Richmond, Virginia in August of 1817. Later that year, 3000 blacks gathered to discuss the issues germane to colonization. James Forten, who formerly was involved in emigration schemes to Haiti, presided over the discussion. After much discussion, the ACS was unanimously rejected. Like meetings took place in Washington DC, Baltimore, New York, Providence and Boston and everywhere there was a large black community—with like results, colonization schemes were roundly rejected. African Americans largely believed that the ACS was an organ of southern slaveholders designed for "perpetuating their system of slavery, undisturbed." "7 Cornish asserted that African Americans loved this nation and that "it was the country of their fathers for generations, and of their own nativity" and where land was available "abundant and cheap," where "labor was in demand" and "education could be obtained." And so, blacks had no desire to return to Africa. ${ }^{8}$

Besides a more vigorous biblical defense of slavery, South Carolina began to crackdown on the threat of rebellion. In June, 1822 the plot of rebellion led by Denmark Vesey and his co-conspirators was uncovered in Charleston while in its planning stages. The Charleston authorities wasted little time dealing with those who were allegedly involved executing them within a month. They also, out of fear of future rebellions, used the opportunity to pass repressive laws designed to curtail slaves' access to free blacks

\footnotetext{
${ }^{7}$ Samuel E. Cornish and Samuel Eli, The colonization scheme considered: in its rejection by the colored people, in its tendency to uphold caste, in its unfitness for Christianizing (Newark, NJ: 1840) 4-5, Sabin Americana, Gale, Cengage Learning, (accessed April 18, 2017).

${ }^{8}$ Ibid., 5-6.
} 
from out of town by passing the Negro Seaman's Act that required visiting black seamen to stay in the local jail while their ship docked in any South Carolina port. Some South Carolinians felt the Seaman statute, and other South Carolina laws already prohibiting slave literacy did not go far enough to restrict slaves from assembling or reading religious materials, but their petitions went unheeded by the state legislature. ${ }^{9}$ But if the South Carolina authorities thought they would not hear again about antislavery agitation through the seamen, they were mistaken. A resident of Charleston, David Walker, left the city and did just that.

It's not exactly known when David Walker was born. His first biographer, Henry Highland Garnet, has his birth at September 28, 1785 in Wilmington, North Carolina to a free mother and an enslaved father. His father died before David was born. According to Garnet, Walker knew at an early age that he hated slavery and "his soul became so indignant at the wrongs which his father and his kindred bore" and soon decided to leave the South vowing that "as true as God reigns, I will be avenged for the sorrow which my people have suffered." When old enough he left North Carolina, and wound up in Boston, Massachusetts. ${ }^{10}$ The investigation of Walker's story by Peter P. Hinks, however, has Walker's birth at in 1796 or 98 in Wilmington, North Carolina. He was born free but his

\footnotetext{
${ }^{9}$ Hinks, Awaken My Afflicted Brethren, 30; Forbes, "The Missouri Controversy," 91-92; Nicholas May, "Holy Rebellion: Religious Assembly Laws in Antebellum South Carolina and Virginia," The American Journal of Legal History 49, no. 3 (2007): 237-56. http://www.jstor.org.ezproxy.fiu.edu/stable/25664424, (accessed April 18, 2017).

${ }^{10}$ David Walker and Henry Highland Garnet, 1830, Walker's appeal: with a brief sketch of his life (New York: Printed by J.H. Tobitt), v, http://find.galegroup.com/sas/infomark.do?docType=ECCO\&contentSet=ECCO\&type=getFullCitation\&ta $\mathrm{bID}=\mathrm{T} 001 \&$ prodId $=$ SAS\&version $=1.0 \&$ docLevel $=$ TEXT_GRAPHICS\&resultListType $=$ RESULT_LIST\& bookId=SSM000A6847100\&source=library, (accessed April 18, 2017).
} 
parents are unknown. He managed to gain an education possibly among the Methodists where he also attended church and developed his faith. When ready to seek employment he found Wilmington to be a tough place to find work, so he moved to Charleston, South Carolina between 1810 and 1815 where he expected to find work. When he arrived he became a member of the Charleston AME church where he possibly came in contact with Denmark Vesey and became aware of Vesey's plot for slave rebellion. When the plot was discovered Walker soon made his way to Boston, Massachusetts where he settled and gathered his thoughts for his Appeal. ${ }^{11}$

When David Walker put pen to paper in 1829 , he had seen enough of slavery to make him feel that the nation had reached the apex of its depravity. Indeed, as Garnet asserted, probably using Walker's widow as a source, Walker declared his soul was “indignant at the wrongs which his father and his kindred bore." He further asserted in explaining why he must leave Wilmington "I cannot remain where I must hear their chains continually, and where I must encounter the insults of their hypocritical enslavers. Go, I must.” In the opening of his Appeal Walker declared that he "had travelled over a considerable portion of these United States" and "taken the most accurate observations of things as they exist." Walker's conclusion after his "observations" was that "we, (colored people of these United States) [sic] are the most degraded, wretched, and abject set of beings that ever lived since the world began..." That Walker began his career as an abolitionist by travelling to take a "accurate observations of things as they exist" hearkens to when Moses, as recorded in Exodus 2:11 and Acts 7:23, "went out to where his own people

\footnotetext{
${ }^{11}$ Hinks, Awaken My Afflicted Brethren, 11-38, 62-64.
} 
were and watched them at their hard labor." Whether he saw himself as a Moses figure we cannot tell, however, he framed his Appeal in biblical language. ${ }^{12}$

African American “wretchedness" under American slavery were indeed on display. In several ways, that "wretchedness" was apparent to Walker. He decried the brutal treatment of his brethren at the hands of slaveholders.

They brand us with hot iron - they cram bolts of fire down our throats - they cut us as they do horses, bulls, or hogs - they crop our ears and sometimes cut off bits of our tongues - they chain and handcuff us, and while in that miserable condition, beat us with cow-hides and clubs - they keep us half naked and starve us sometimes nearly to death...they put us fifty-sixes and chains, and make us work in that cruel situation, and in sickness... ${ }^{13}$

Walker's many years observing slavery allowed him, like Moses, to note the harshness of American slavery which included cruelty, mutilation, and neglect. Dehumanization to the point of treatment as cattle is an issue Mia Bay has noted as she charted how former slaves described their former treatment while in bondage. Walker also noted the maltreatment of women and children who were in bondage and he urged those in bondage to take note as well. Walker hearkened "the bosoms" of "loving wives heaving with untold agonies" and lamented "the cries of poor children." Fathers "bore" the "stripes," while mothers were "tortured" and filled with "disgrace" due to American slavery. Speaking directly, as Bourne did, Walker decried the violent sexual exploitation that enslaved women endured in American slavery. He called those who thus exploited enslaved women, in a biblical term, "incarnate devils."14

\footnotetext{
${ }^{12}$ Walker and Garnet, Walker's Appeal, vi.

${ }^{13}$ Walker, Appeal, 65.

${ }^{14}$ For Mia Bay's analysis of how African Americans defended their humanity see her chapter titled "Us is Human Flesh: Race and Humanity in Black Folk Thought" in her The White Image in the Black Mind:
} 
Like Bourne, Walker also excoriated hypocritical religion in encouraging the oppression of enslaved blacks. His rebuke came with a warning the nation for relying on false religion to perpetuate an oppressive system. "Will the Lord suffer this people to go on much longer, taking his holy name in vain? Will he not stop them, PREACHERS and all? Americans! Americans!! I call God-I call angels—I call men, to witness, that your DESTRUCTION is at hand, and will be speedily consummated unless you REPENT.” Walker appealed to God as his authority in calling out false religion. He proclaimed that he was not speaking lightly, or "using the Lord's name in vain" when issuing his warning of divine retribution. Walker maintained that African Americans did not owe their freedom to white Americans, but only to the third member of the Trinity—-the Holy Spirit. Freedom was their "natural right" as God's creatures. "Should tyrants take it into their heads to emancipate any of you, remember that your freedom is your natural right. You are men, as well as they, and instead of returning thanks to them for your freedom, return it to the Holy Ghost, who is your rightful owner." There is biblical precedent for what Walker asserts in terms of the notion of being innately free through Christ's Spirit but that freedom being usurped by man. The Apostle Paul often wrote on freedom: "Now the Lord is the Spirit, and where the Spirit of the Lord is, there is freedom." "It is for freedom that Christ has set us free. Stand firm, then, and do not let yourselves be burdened again by a yoke of slavery."

"This matter arose because some false brothers had infiltrated our ranks to spy on the freedom we have in Christ Jesus and to make us slaves." 15

African American Ideas about White People (New York, NY: Oxford University Press, 2000), 117-149; Walker, Appeal, 65.

${ }^{15}$ Scriptures cited are 2 Corinthians 3:17; Galatians 5:1; Galatians 2:4. 
Walker asserted that white Americans, therefore, had no right to enslave African Americans who belong to Jesus Christ just as much as white Americans. "Have we any Master," Walker declared, "but Jesus Christ alone? Is he not their Master as well?_What right then, have we to obey and call any other Master, but [Christ]?” For these reasons, Walker, like other African Americans, rejected the colonization of blacks to Africa. Walker declared what he believed to be the inconsistent position of white Americans regarding blacks. "[W]e ought not to be set free in America, but ought to be sent away to Africa!!!- That if we were set free in America, we would [lead] the country in a civil war..."16

Because of the sum of villainies that was American slavery, Walker declared that the United States had reached the limits of their oppression. The biblical term he used was "their cup is full." Like Bourne, who had spent some time in Virginia, and the Grimke sisters also in Charleston at the time, Walker would have seen the domestic slave trade ravage the families of slaves in his travels throughout the south. In the decade of the 1820s South Carolina sold off over 20,000 slaves and it was only getting started. In the next 3 decades, it would sell off over 171,000 slaves. ${ }^{17}$ Virginia sold off 75,562 in the 1810 s and 76,157 in the 1820 s. Maryland sold 33,070 and 32,795 respectively in the same period. North Carolina, Walker's home state, sold 13,361 and 20,113 in that time. ${ }^{18}$ Each slave sold likely represented a ruptured marriage or family unit. American slavery

\footnotetext{
${ }^{16}$ Appeal, 43, 16, 66.

${ }^{17}$ Tadman, Speculators and Slaves, 12.

${ }^{18} \mathrm{Ibid}$.
} 
was ruining the lives of African Americans and Walker had much to say to America in a jeremiad laced with an urgent warning that the time for divine retribution was at hand:

Respecting slavery, which is ten thousand times more injurious to this country than all the other evils put together; and which will be the final overthrow of its government, unless something is very speedily done; for their cup is nearly full. [emphasis mine]--Perhaps they will laugh at or make light of this; but I tell you Americans! that unless you speedily alter your course, you and your Country are gone!!!!!! For God Almighty will tear up the very face of the earth!!! Will not that very remarkable passage of Scripture be fulfilled on Christian Americans? Hear it Americans!! "He that is unjust, let him be unjust still:--and he which is filthy, let him be filthy still: and he that is righteous, let him be righteous still: and he that is holy, let him be holy still." ${ }^{19}$

Walker warned Americans that "slavery" is "ten thousand times more injurious to this country than all other evils put together." And He warned that it will be the "final overthrow of the government" if something is not "speedily done." If Americans did not repent of the sin of slavery, Walker emphatically warned that, "you and your Country are gone!!!!!!" The notion that America's "cup is nearly full" is a metaphorical allusion to a biblical reference in Psalm 75:7-9 of divine retribution. In this reference God judges the wicked of the earth "exalting one" and "humbling another." In his hand is a "cup full of foaming wine mixed with spices" which he "pours out" on the "wicked of the earth." Therefore, that America's cup is nearly full means that God's judgment is close at hand and fast approaching. ${ }^{20}$

This idea of a "full cup" is a millennial term that is alluded to in the book of Revelation 14:10 where the wrath and fury of God are metaphorically called the "cup of

\footnotetext{
${ }^{19}$ Walker, Appeal, 45.

${ }^{20}$ See also pages 14, 24, 42 of Walker's Appeal.
} 
his wrath." ${ }^{21}$ Walker uses this theme in Revelation as a warning for America and the threat of divine retribution:

But there is a day fast approaching, when (unless there is a universal repentance on the part of the whites, which will scarcely take place, they have got to be so hardened in consequence of our blood, and so wise in their own conceit.) [sic] To be plain and candid with you, Americans! I say that the day is fast approaching, when there will be a greater time on the continent of America, than ever was witnessed upon this earth, since it came from the hand of its Creator. Some of you have done us so much injury, that you will never be able to repent.--Your cup must be filled. [emphasis mine]--You want us for your slaves, and shall have enough of us--God is just, who will give you your fill of us... ${ }^{22}$

For Walker, "there is a day fast approaching" and the only thing that can avert it is universal repentance. However, Walker is not optimistic that there will be universal repentance because Americans might have done "so much injury, that you will never be able to repent." Because of her stubborn depravity and greed, Walker was not optimistic of the prospects of America repenting of the sin of slavery. Respecting that depravity and greed he commented that part of divine retribution is God's patience with the wicked to give them, in effect, enough rope to hang themselves:

Thus we see the depravity of men's hearts, when in pursuit only of gain-particularly when they oppress their fellow creatures to obtain that gain--God suffers some to go on until they are lost forever. ${ }^{23}$

Walker witnessed South Carolina's response to the Missouri Controversy and the Vesey Affair and surmised there that very little could cause the slave state to humbly

\footnotetext{
${ }^{21}$ See also Revelation 16:19; 17:4; 18:6.

${ }^{22}$ Walker, Appeal, 54-55.

${ }^{23}$ Walker, Appeal, 56.
} 
repent of slavery. He also witnessed the state's intent on profiting from the domestic slave trade, even if it meant destroying African American families. He likely observed the resolute, strong and aggressive nature of the westward expansion of slavery. Walker therefore concluded that the nation was deeply entrenched in the system that had become so vital to its economy. Walker therefore saw God giving America over to "depravity" and a "reprobate mind" because of her intent to make a profit through the oppressive institution:

This is a fair illustration of the state of society in this country--it shows what a bearing avarice has upon a people, when they are nearly given up by the Lord to a hard heart and a reprobate mind, in consequence of afflicting their fellow creatures. God suffers some to go on until they are ruined for ever!!!!! [sic $]^{24}$

Walker's critique of the United States was based on a comparison to Egypt, the oppressive nation described in the emancipatory story of Exodus. Here Walker made an interesting observation coupled with a refrain he mentioned in the preceding quotes. That America, because of her avarice, was "nearly given up by the Lord to a hard heart and a reprobate mind, in consequence of afflicting their fellow creatures." Here a "hard heart" and a "reprobate mind" are coupled together. And they are a form of divine retribution and "ruin" at the hands of God. This is an implicit reference to the Exodus account in which, as it were, God hardened Pharaoh's heart in order to bring his full complement of 10 plagues on him and Egypt, as well as the final demise of the army in the Red Sea. Because the Pharaoh refused to repent of his enslavement of the Israelites, God decreed that his nation must feel the full measure of his wrath. ${ }^{25}$ By virtue of their "hardened"

\footnotetext{
${ }^{24}$ Walker, Appeal, 46.

${ }^{25}$ See also Exodus 7:3; 9:12; 10:20; 11:10; 14:4.
} 
hearts and "reprobate" minds, Americans would foolhardily plunge headlong into their own destruction. By using the word "reprobate" to describe the mindset of America Walker was indeed saying that America, insofar as her insistence on "afflicting" slavery on her "fellow creatures," had become "morally depraved, unprincipled; bad and had been given up on and rejected by God and beyond hope of salvation." It was America's cruelty and sexually exploitive institution of slavery that prompted Walker to call America "depraved" and of a "reprobate mind."

Having toured the South and studied slavery, Walker made the case that African Americans were victimized by the breaking up of families, the not too infrequent use of slave girls for a means of sexual fulfillment by slave owners, and the way fugitive slaves were hunted down and forcibly retrieved by their masters. These acts were slowly but surely filling America's cup. And for Walker the hardening of America was taking place before his eyes and its cup was almost at capacity. In other words, America was developing a reprobate and depraved mind, and was not ready or able to repent. Because of the dim prospects for repentance Walker foresaw divine retribution:

[B]ut I tell you Americans! that unless you speedily alter your course, you and your Country are gone!!!!!! For God Almighty will tear up the very face of the earth!!!26 Walker's prescient prediction of civil strife begs the question of where he might have summoned such a notion? He did not quote any scripture nor did he invoke any biblical example of civil strife as a form of divine retribution. Yet there are biblical references and precedents that point to that point to divine retribution through civil strife. Granville Sharp wrote as much in his Law of Retribution. In referring to the Revolutionary War, he called the conflict "our present Civil Dissensions and horrid mutual Slaughters of

\footnotetext{
${ }^{26}$ Walker, Appeal, 46.
} 
National Brethren" and a cited the scripture in Isaiah 19:2-3 to aver that the British Empire and its Colonies were under "Divine Vengeance" for "oppression." In the scripture that Sharp invoked the Prophet Isaiah proclaimed that "I (the Lord, or Jehovah) [sic] will set THE EGYPTIANS against THE EGYPTIANS: and they shall fight every one against his Brother, and every one against his Neighbour; City against City, (and) [sic] Kingdom against Kingdom. And the Spirit of Egypt shall fail in the midst thereof; and I will destroy the council thereof!'” Without quoting the scripture, Walker was predicting that the same thing would happen in the United States because of slavery. Besides this quote, there are several other instances in the Bible that describe God's working among men to divide them as a part of divine retribution for past sins. Walker likely was heartened by these scriptures and it is also quite possible that Walker made his prediction with biblical instances in mind but just opted to leave the references out. ${ }^{27}$

The Appeal made its way down south and wreaked havoc. Arrests were made in Georgia, Virginia, North Carolina, South Carolina and Louisiana of men who were caught with the Appeal and its "inflammatory" language. George Gilman, Georgia's Governor, was incensed when he discovered 60 copies of the Appeal in his state. He wrote Harrison Grey Otis, the Mayor of Boston, urging him to silence and extradite Walker. Otis refused both requests. Many of the states quickly reinforced their laws against slave literacy and further curtailed black religious activity while cracking down on free black interaction with the slave populations. These laws were a response to reports that the Appeal was being read by free blacks to illiterate slaves. Rumors of slave

\footnotetext{
${ }^{27}$ Sharp, Law of Retribution, 226; Judges 7:19-22; Judges 9:23-24, 56; 1 Samuel 14:20-23; 1 Kings 12:1-
} 24. 
rebellions in connection to Walker's Appeal abounded. In further response new southern laws provided serious penalties for distribution of literature that was seditious in nature or made blacks "discontented or insubordinate." These laws carried with them penalties that included life imprisonment or death. Georgia wanted Walker dead or alive and some from that state took a vow to eat little until they apprehended Walker. Walker received word that there was a bounty on his heard but refused to flee Boston for Canada as his family urged him to. Within a year, he was dead, presumably from poisoning. ${ }^{28}$

When Walker died, Maria W. Stewart lost someone she deeply admired. To her he would always be "the most noble, fearless, and undaunted David Walker" and she relished the thought of becoming a "martyr" in "pleading the cause of oppressed Africa" like her friend. ${ }^{29}$ Born in 1803 in, Stewart became an orphan at the age of five. She grew up in a minister's family where she developed her Christian convictions. She took the initiative to educate herself, learn how to read and acquire Christian instruction. Stewart married James W. Stewart, veteran of the War of 1812, at the age of 23. It was around the time of her marriage in 1826 that she made the acquaintance of David Walker and developed a friendship that would influence her for years to come. Within three years of marriage James took ill and never recovered and passed away leaving Stewart a widow. That year, Walker published his Appeal that not only made an impact on the emerging antislavery discourse, had a deep impression on Stewart. When her now good friend

\footnotetext{
${ }^{28}$ Garnet, Walker's Appeal, vi-vii; Hinks, My Afflicted Brethren, 119-150.

${ }^{29}$ Maria Stewart, Meditations from the pen of Mrs. Maria W. Stewart, 24.
} 
Walker died, Stewart tried her hand at abolitionist writing and took a manuscript to William Lloyd Garrison. Garrison was impressed enough to publish her work in The Liberator in 1831, the paper's inaugural year. Thus she became the first black woman to publicly oppose American slavery. ${ }^{30}$

Like Walker, Stewart framed the African American experience in biblical terms and issued her own warning to the United States. Stewart cried out:

$\mathrm{O}$, America. America, foul and indelible is thy stain! Dark and dismal is the cloud that hangs over thee for thy cruel wrongs and injuries to the fallen sons of Africa. The blood of her murdered ones cries to heaven for vengeance against thee. Thou art almost drunken with the blood of her slain; thou hast enriched thyself through her toils and labors; and now thou refuseth to make even a small return. And thou hast caused the daughters of Africa to commit whordoms and fornications; but upon thee be their curse. ${ }^{31}$

Just like that, Stewart summarized the sum of villainies that made up American slavery. Never had one paragraph been so pregnant with all the charges and warnings that immediatist abolitionists pinned on the system of American bondage. First, the charge was against all of America—not just the South. Second, the ominous clouds that hung over the nation were a portend of divine retribution for slavery. Third, as the blood of Abel that cried out to God in the book of Genesis, African blood cried out to God for vengeance in America. Fourth, the nation had become rich on the backs of slaves. Fifth, untold numbers of enslaved women had been personally victimized and induced to sexual immorality and the curse remained on American slavery for such misconduct.

\footnotetext{
${ }^{30}$ Maria W. Stewart and Marilyn Richardson, Maria W. Stewart, America's first Black woman political writer: essays and speeches (Bloomington: Indiana University Press, 1987), 3-27.

${ }^{31}$ Ibid., 33.
} 
The tentacles of American slavery stretched from North to South as the domestic slave trade left a trail of human misery from states as north as Delaware and by 1831 reached as far southwest as states such as Louisiana, Arkansas and Missouri. ${ }^{32}$ Furthermore, northern banks financed speculators in human flesh. ${ }^{33}$ Stewart, therefore, blamed all of America for slavery and not just the South. Whereas Bourne focused on the South, and especially the churches for their complicity with slavery, Stewart maintained that the whole nation was responsible for the institution. Like Granville Sharp, who blamed the entire British Empire including the American colonies for their complicity regarding slavery, Stewart understood that both the South and the North shared some blame for "the stain" that was American slavery. Northern states had initially acquiesced to the demands of their southern constitutional delegates in allowing the constitutional compromises that protected property in humans. While American slavery thrived in the South, northern banks and financial institutions supported and sustained its growth and expansion. About 20,000 northern cotton mill workers processed southern cotton. Northern courts cooperated with the capture and return of fugitive slaves to the South. ${ }^{34}$ Like other immediatist abolitionists, Stewart predicted there would be divine retribution for the nation over American slavery. Her reference to "dark and dismal is the cloud that hangs over thee" is a metaphor for impending doom for the nation. All the

\footnotetext{
${ }^{32}$ Michael Tadman, "The Interregional Slave Trade in the History and Myth-Making of the U.S. South," in Walter Johnson, ed. The Chattel Principle (New Haven: Yale University Press, 2004), 119.

${ }^{33}$ Baptist, The Half has never been told, 33-34, 90-91; Sven Beckert, The Monied Metropolis: New York City and the Consolidation of the American Bourgeoisie, 1850-1896 (Cambridge, UK: Cambridge University Press, 2001), 117.

${ }^{34}$ Baptist, The Half has never been told, 318.
} 
antislavery critics, save for a very few, issued urgent warnings of divine retribution for slavery unless redressed. Walker most recently cried that if the nation did not repent, their country would "be gone." Abolitionists maintained that the cruelty of American slavery was so heinous that it begged for divine retribution. Stewart cried that the "dark and dismal" clouds hung over the nation because of its "cruel wrongs and injuries to the fallen sons of Africa." Stewart was clear that she did not believe that American slavery was a paternal institution. It was cruel, wrong and injurious to "the sons of Africa." If abolitionists went into detail about American slavery, it was to demonstrate how cruel, wrong and injurious it was and as such begged for redress, even by God.

African American blood shed while in captivity was a theme that abolitionists used in their critique of slavery. Stewart, likewise, issued a biblical reference of innocent African blood that must be avenged by God. Though she did not provide chapter and verse, the reference to "the blood of her murdered ones cries to heaven for vengeance against thee" is pregnant with biblical and emotional meaning. First, there is the matter of blood "crying out for vengeance against thee" is a reference of the story of Cain and Abel as recorded in Genesis. When Abel was murdered by his brother Cain, God said to Cain, "what have you done? Listen! Your brother's blood cries out to me from the ground." Stewart contended that America had done to the Africans what Cain had done to Abel and African blood therefore was "crying out for vengeance" against America. The other meaning in this sentence is the personification of Africa as a woman and mother who mourned because her children had been murdered. When Herod ordered the extermination of all the children less than two years of age in Bethlehem in his attempt to kill the baby Jesus, the writer called it a fulfillment of prophecy: 
"A voice is heard in Ramah, weeping and great mourning, Rachel weeping for her children and refusing to be comforted, because they are no more." 35

In the context of American slavery, Stewart was implicitly comparing the United States to Herod. And though the blood of Africans made no audible sound, Stewart maintained that spiritually speaking, the blood, which "cried for vengeance" was clear to God.

American slavery was a lucrative institution for $19^{\text {th }}$ century United States. Stewart maintained that America had become rich through the toil of enslaved Africans. While she did not provide facts and figures to bolster her claim, the wealth of the nation due to slavery was real. The U.S. Treasury was filling up due to the cotton induced revenue that was pouring in. The United States, by 1831, was becoming a financial powerhouse because of cotton. Whereas in 1791 the U.S. produced 0.4 percent of the world's cotton, by 1831 the U.S. produced 49.6 percent. ${ }^{36}$ Whereas the value of American cotton in 1791 stood at less than one million dollars, by 1831 it stood at 38.5 million dollars. In today's value that would be over 2 trillion dollars. ${ }^{37}$ Whereas the value of American cotton exported was at 17.5 million dollars, in 1831 it stood at 25.2 million dollars (1.2 trillion today) and was ascending. ${ }^{38}$ Within 5 years it would almost triple to 71.2 million (3.5 trillion today).${ }^{39}$ From 1820 to 1830 the national economy had grown 38 percent. ${ }^{40}$

\footnotetext{
${ }^{35}$ Matthew 2:18; Jeremiah 31:15.

${ }^{36}$ Stuart Weems Bruchey, Cotton and the growth of the American economy, 1790-1860: sources and readings (New York: Harcourt, Brace \& World , 1967), 7, Table 1A.

${ }^{37}$ Ibid., 8, Table 2A.

${ }^{38}$ Ibid., 22, Table $3 \mathrm{~K}$.

${ }^{39}$ Ibid.
} 
Whereas in 1790 the total U.S. wealth in slaves was roughly 200 million dollars (10 trillion today), by 1830 that number had grown to 577 million dollars (28.8 trillion today). ${ }^{41}$ Meanwhile, the enslaved, bearing the brunt of the burden, shared none of the wealth.

Fifth, untold numbers of enslaved women had been personally victimized and induced to sexual immorality and the curse remained on American slavery for such misconduct. Stewart's words were guided by the evangelical zeal for sexual morality. She, like Bourne, was a severe critic of that part of American slavery that involved sexual exploitation. Unlike Bourne, however, he was not as explicit in her description of the sexual nature of the institution. Like Bourne she blamed America for any of the "whordoms and fornications" committed by enslaved women because they were "induced" as women without rights to have a say with what happened with their bodies. As such, the "curse" for the "whordoms and fornications" of the enslaved women fell on the nation that so exploited them. She had more to say on this subject. In another address, she likened the U.S. to Babylon:

It appears to me that America has become like the great city of Babylon, for she has boasted in her heart, -'I sit a queen, and am no widow, and shall see no sorrow? She is indeed a seller of slaves and the souls of men; she has mad the Africans drunk with the wine of her fornication; she has put them completely beneath her feet, and she means to keep them there; her right hand supports the reins of government, and her left hand the wheel of power, and she is determined not to let go her grasp. ${ }^{42}$

\footnotetext{
${ }^{40}$ Baptist, The Half has never been told, 229.

${ }^{41}$ Baptist, The Half has never been told, 246.

${ }^{42}$ Maria W. Stewart, Productions of Mrs. Maria W. Stewart: presented to the First African Baptist Church $\&$ Society of the city of Boston (Boston, 1835), 71, Sabin Americana, Gale, Cengage Learning, (accessed April 18, 2017).
} 
Stewart likened the U.S. to Babylon by invoking the millennial image recorded in Revelation 18. The Babylon of Revelation had "fallen" and had "become a dwelling for demons" because the city had "committed adultery" and the "merchants of the earth grew rich from her excessive luxuries." Babylon also dealt in the commerce of all kinds of cargoes which included "human beings sold as slaves" or "the souls of men." Stewart appropriated the metaphor of Babylon and compared it to the U.S. in terms of wealth, power, sexual immorality and the domestic slave trade. On all accounts, America compared to Babylon; and just as Babylon had fallen, America would also fall due to divine retribution. This, of course, is not the first time the U.S. would be compared to Babylon or Egypt for that matter. Prior abolitionists and critics of American slavery like Granville Sharp and Benjamin Lay compared the slaveholding U.S. to Babylon and Egypt, nations noted in the Bible for oppression. And it was on that basis that they made the case that the nation was liable to divine retribution. Only here, Stewart was also following Walker's lead in comparing the plight of African Americans as a spiritual Israel under oppression. Doing so, she gave public voice to the notion of African Americans as a nation and a people of God.

Abolitionists who used the Bible to critique American slavery believed that there must be a price to be paid for the sin of slavery. Stewart, likewise, predicted divine retribution on America because she believed that the prayers of the African Americans had been heard by God. Perhaps like others thinking of the uprising of St. Domingue, and Nat Turner's bloody rampage in Virginia, she envisioned the enslaved African Americans, rising up to reject sexual immorality and claim their freedom as major players in that divine retribution. The scene made her tremble with fear: 
But many powerful sons and daughters of Africa will shortly arise, who will put down vice and immorality among us, and declare by Him that sitteth upon the throne, that they will have their rights; and if refused, I am afraid they will spread horror and devastation around. I believe the oppression of injured Africa has come up before the Majesty of Heaven; and when our cries shall have reached the ears of the Most High, it will be a tremendous day for the people of this land; for strong is the arm of the Lord God Almighty. ${ }^{43}$

Here Stewart mixes her biblical metaphors. While continuing to assert her argument that America would face divine retribution, she appropriates and adds the story of Exodus in which the Israelites "groaned in their slavery and cried out, and their cry for help because of their slavery went up to God. God heard their groaning..."44 In this scenario, the enslaved Africans are likened to the Israelites and their prayers have also been heard, just as the Israelite prayers were heard by God. The U.S., besides being Babylon, is also now compared to Egypt and if Egypt was punished, so would America. As such, she urged the Americans to not become arrogant and think that they could not be stopped. Stewart warned America to not scoff at the warning of divine retribution or he haughty of its powers especially over the enslaved Africans. Her warning was bold:

You may kill, tyrannize, and oppress as much as you choose, until our cry shall come up before the throne of God; for I am firmly persuaded, that he will not suffer you to quell the proud, fearless and undaunted spirits of the Africans forever; for in his own time, he is able to plead our cause against you, and to pour out upon you the ten plagues of Egypt. We will not come out against you with swords and staves, as against a thief; but we will tell you that our souls are fired with the same love of liberty and independence with which your souls are fired. ${ }^{45}$

\footnotetext{
43 Ibid., 71.

${ }^{44}$ Exodus 2:23-24.

${ }^{45}$ Stewart, Productions, 19.
} 
Though Stewart referenced the possible uprising of the Africans, she encouraged them to patiently wait for God to deliver them from bondage. Stewart believed that the war on their degraded condition and slavery required spiritual weaponry. Africans must not fight with the weapons of this world though they be degraded as a people. They must "out of fear of Him who is able, after he had killed, to destroy both soul and body in hell" control their anger and "passions" and "sheath your swords." She urged her "brethren" to "stand still and know that the Lord is God." Stewart assured her brethren that "Vengeance is his, and he will repay." Ultimately it was this assurance of faith that God, a God of vengeance, heard their prayers as he heard the prayers of the oppressed Israelites in Egypt. He would repay America in due time for all the troubles Africans endured at their hands. As an African American abolitionist, she believed that a weapon she and other opponents of slavery was knowledge. Africans must, therefore, not allow themselves to be "discouraged," but must now turn to God who "is able to fill you with wisdom." Stewart proclaimed to her downtrodden people that "knowledge is power." 46 Other weapons that Stewart urged upon African Americans was prayer and Bible study. It was prayer that would help her people "dispel your fears." Africans must "arm yourselves with the weapons of prayer." Rather than give way to fear, Africans must put their "trust in the living God." It was prayer that would bring about their deliverance-a deliverance brought about by God in his own time. "Let nothing be lacking on your part," Stewart entreated, "and in God's own time, and his time is certainly the best, he will surely deliver you with a mighty hand and with an outstretched arm." Stewart was deeply

\footnotetext{
${ }^{46}$ Ibid., 26, 29, 35.
} 
religious and she bathed her thoughts in biblical language. Her worldview was thoroughly colored with biblical hue and she defined the United States, African Americans, slavery, and just about any topic that she addressed in Old and New Testament language and metaphors. "I have borrowed much of my language," Stewart related, "from the Holy Bible." Stewart had been trained in the scriptures since childhood. "During the years of childhood and youth," Stewart wrote, "it was the black book that I mostly studied; and now, while my hands are toiling for their daily sustenance, my heart is most generally meditating upon its divine truths." She believed that "the black book" would have to be used for "the chains of slavery" to be destroyed and it was incumbent on "professing followers of Christ" to "arise and shine forth, and prove to the world that there is a reality in religion." ${ }^{47}$

The Bible provided the principles that Stewart used to launch her critique of the United States and the sin of American slavery. Though she fundamentally loved this nation and called it "the land of freedom" in which "the press is at liberty" and "every man has a right to express his opinion;" she took issue with and rejected any American notion that the African was inferior simply because their "skins are tinged with a sable hue." Speaking to the African Americans, Stewart asserted that "God does not consider you as such. He hath formed and fashioned you in His own glorious image, and hath bestowed upon you reason and strong powers of intellect." Stewart further asserted that far from their lowly state in this nation, God "hath made you to have dominion over the beasts of the field, the fowls of the air, and fishes of the sea. He hath crowned you with

\footnotetext{
${ }^{47}$ Ibid., $35,36$.
} 
glory and honor; hath made you but a little lower than the angels..." She also noted that "according to the Constitution [probably referring to the Declaration of Independence] of these United States, he hath made all men free and equal." Stewart, therefore, scoffed at any notion that white people were superior when that was not the intent of the Creator. "It is not the color of the skin that makes the man," Stewart proclaimed, "but it is the principle formed within the soul." 48

America was not ready for the likes of Maria Stewart or David Walker. Though Garrison was supportive to the end, within a couple of years, she was forced to leave public life. Like Walker, her fiery antislavery speeches proved to be intolerable for white crowds who hardly tolerated white men like Garrison. It was one thing for a white male to criticize the U.S. and quite another for a black woman, or black man like David Walker, to declare white America to be guilty of a national crime. On September 21, 1833, she delivered her farewell address, just less than 2 years after delivering her first address in October 1831. Her farewell address, however, provided a glimpse into her soul as she shared the reasons why she was emboldened to speak on behalf of her enslaved brothers and sisters. She had been encouraged by Garrison and Isaac Knapp because her "female influence was powerful." Stewart felt "I had a work to perform" and so she worked hard to do her part to forward the cause. But speak as she did, her status as a woman was constantly in question. Stewart could not understand why that made a difference. "What if I am a woman?" She hearkened to important women in the Bible who served God like Deborah, Queen Esther and Mary, and believed that if God could use them, he could use her as well. Yet, despite her desire to be a meaningful voice in the

${ }^{48} \mathrm{Ibid}$. 
emerging movement, Stewart would have to acquiesce. Stewart went on with her life by taking a position as a teacher in New York. Stewart's exit, however, signaled the beginning of women public involvement in the abolitionist movement. Others would follow, namely the Grimke sisters to lend their voices to a movement that was beginning to grow in influence and impact in the U.S. 


\section{CHAPTER VI}

\section{Immediate Abolition, the Bible and Women}

William Lloyd Garrison is considered the iconic leader of the $19^{\text {th }}$ century American immediatist abolitionist movement. And his famous declaration on January 1, 1831 when he famously vowed that "I WILL BE HEARD," is considered the opening salvo of that movement. Exploring the origins of the movement, however, through a different paradigm that traces how the Bible was applied by abolitionists to the system of American slavery, uncovers other key abolitionists that played a key role in the early development of the movement. The American immediatist abolitionist movement that Garrison gets credit for starting, had at its roots in it a biblical system of thought that the obscured George Bourne authored. Moreover, what gave that movement its impulse was a biblical critique of American slavery that exposed how the system dehumanized African Americans, victimized African American women and destroyed African American families. This line of argument engaged and galvanized women like Sarah and Angelina Grimke into the movement who themselves biblically arraigned American slavery, and inspired other women to become activists and campaigners against the oppressive system. ${ }^{1}$

George Bourne and his biblical writings influenced Garrisons in the early days of the abolitionist movement. This point has been implied and even argued before. ${ }^{2}$ What has not been argued is the sustained influence on Garrison that Bourne had in the early

\footnotetext{
${ }^{1}$ Quote by William Lloyd Garrison in The Liberator, January 1, 1831.

${ }^{2}$ John L. Thomas, The Liberator William Lloyd Garrison: A Biography, 104-105; Christie and Dumond, George Bourne and The Book and Slavery Irreconcilable, vii-viii.
} 
years of the immediatist movement, especially with targeting women for engagement in the campaign against American slavery. The early years of Garrison's paper, the Liberator, provides clues as to the regard that Garrison had for Bourne's convictions about the "sinfulness" of American slavery. It is also evident that Bourne, and later the Grimké sisters, Sarah and Angelina, awakened and strengthened Garrison's impulse to focus engage women to join the cause on behalf of their sisters in bondage. An exploration of Bourne's writings between the years of 1816 and 1837, as well as the Grimké's writing in 1836 and 1837, juxtaposed to the events between 1831 and 1837 provide indications that Bourne's biblical writings inspired Garrison to immediate abolitionism and his inclusion of women into the abolitionist movement while the Grimké's emergence and antislavery writings further supported the engagement of women into the crusade against American slavery.

The abolition of slavery in the British Empire in 1833 was a seminal moment in the Transatlantic Antislavery movement as American abolitionists were inspired by the victory won against slavery across the Atlantic. Arthur and Lewis Tappan, New York businessmen, took note and summoned a group of men they thought capable of launching such a movement in the U.S. It was probably not lost on the Tappans, evangelicals themselves, that the British effort had a strong revivalist and evangelical aspect to it as members of the Clapham sect that actively promoted a largely moral and biblical antislavery message. It therefore probably made sense to duplicate a similar religious thrust in the U.S. To be sure, Americans were already looking at ways to eradicate slavery in the U.S. and the Tappans had already begun as early as 1831 to bring together men they thought could launch a campaign in the U.S. Bourne was one of the men they 
tapped early on. The other men that joined the Tappans at that original meeting were Joshua Leavitt, Simeon Jocelyn, William Goodell and Theodore Weld. An evangelical and a Briton, Bourne had credentials that none of these would-be abolitionists possessed. He had witnessed and studied slavery close-up and had applied the Bible to the institution in an unsparing critique, he had a thorough knowledge of the scriptures and was unflinching in his conviction that American slavery was a national sin. He had already published a book on the subject in which he argued that American slavery was "manstealing" and "irreconcilable" to the Bible. And, he was willing to spar with anyone, including his own denomination, on the issue of American slavery — even at the risk of his own career. For the preceding 15 years Bourne had labored in Pennsylvania, Canada and now New York serving the church and had consumed himself in a fight against the Catholic Church. All this was after his skirmish with the Presbyterian denomination ended amicably and allowed him to be restored to the pulpit. Bourne therefore was always ready for a fight. Bourne, however, come with some liabilities. The depth of his convictions made him very opinionated and intolerant to opinions he felt were less informed. Notwithstanding his shortcomings, the Tappans found in Bourne someone who possessed experience with American slavery and the biblical knowledge to articulate a moral and biblical case against the institution. ${ }^{3}$

In Bourne, Tappan and this small group of abolitionists also had an iconoclast who had already authored polemical literature that the group could use launch its recruitment efforts. The group had undoubtedly already read his 1816 publication The Book and Slavery Irreconcilable and understood his depth of insight into the institution

\footnotetext{
${ }^{3}$ Dumond, Antislavery, 175; Barnes, Impulse, 35; Bertram Wyatt-Brown, Lewis Tappan and the evangelical war against slavery (New York: Atheneum, 1971), 104.
} 
they were combating. Furthermore, his biblical stance against slavery was public. Though perhaps his assertions about slavery South were jarring, and directly contradicted southern assurances that theirs was a paternalistic society, the abolitionists could at least be assured that Bourne was a witness with firsthand knowledge of American slavery. Bourne was all too eager to paint a fuller picture for the gentlemen and other potential recruits to form a national antislavery society.

Though he was not at that early 1831 meeting Garrison, a newspaper editor, became interested in antislavery in 1828 when he met Benjamin Lundy, the publisher of the antislavery newspaper titled The Genius of Universal Emancipation. Antislavery attracted the young firebrand but only from the standpoint of a colonization for freed African Americans. Being a neophyte to the issues, Garrison initially adhered to the tenets of colonization and gradual emancipation. That is until he came in contract with Bourne's The Book and Slavery Irreconcilable. The change was almost instantaneous. Whereas on July 4, 1829 he defended the notion of gradual emancipation, by August of the same year he was sharing his newfound faith in immediatism with Lundy and had written a full recantation of gradual emancipation and colonization for Lundy's paper. Within a year, September of 1830 he was writing to a friend and quoting from Bourne's book. ${ }^{4}$ As Garrison admitted to Bourne's son about his father many years later:

"I confess my early and large indebtedness to him for enabling me to apprehend, with irresistible clearness, the inherent sinfulness of slavery under all circumstances, and its utter incompatability with the spirit and precepts of Christianity."

\footnotetext{
${ }^{4}$ Dumond, George Bourne and The Book and Slavery Irreconcilable, 78-80.

${ }^{5}$ William Lloyd Garrison to Theodore Bourne, George Bourne's son Nov. 18, 1858, in Theodore Bourne, Rev. George Bourne: the pioneer of American antislavery, [Louisville, Ky.?], [1882?], Slavery and AntiSlavery, Gale, Florida International University (accessed April 3, 2017).
} 
As the quote suggests, Garrison felt indebted to Bourne for having taught him much about slavery. Indeed, he saw the institution with a "clearness" that revealed its "inherent sinfulness" and its "incompatability" with Christianity. It seems that Garrison himself recognized that he did not see American slavery clearly while he held to gradual emancipation and mass deportation of newly freed African Americans.

It took a man with the experience and biblical knowledge that Bourne possessed to mentor the young inexperienced Garrison in immediate abolitionism. Garrison shared the knowledge he learned from Bourne on the Liberator. The book had a profound impact on Garrison and he began to incorporate its doctrine of the sinfulness of slavery and the need for immediate abolition of slavery right away in the first year of The Liberator's existence in 1831. It was Garrison's practice that inaugural year to place quotations from antislavery authorities prominently in the newspaper. By the end of the year he put together a full page of all the quotes he published in the newspaper that year. Bourne was quoted nine times that year, more than any other antislavery author which included William Wilberforce, Thomas Jefferson, Thomas Branagan and David Rice. Illustrating the regard that Garrison had for Bourne's book, all the quotes, were from Bourne's 1816 The Book and Slavery Irreconcilable. It is a noteworthy that the Bourne quotes that Garrison displayed prominently were biting indictments of slavery, gradual emancipation and the hypocrisy of claiming Christian belief while holding slaves in bondage. These quotes resonated with and influenced Garrison.

The quotes were Bourne's full-throated denunciations of American slavery, "manstealing," slave-holding, and gradual emancipation. The biting commentary that 
came to be hallmarks of Garrison's commentary on the Liberator is evident in Bourne's style and it is easy to see Garrison's affinity to Bourne's style. In one quote Bourne proclaimed, "We assert, that no slaveholder is innocent..." Another he demanded, "Is not the plea, that emancipation is impracticable, the most impudent hypocrisy, and the most glaring absurdity ever propounded for contemplation?" Yet another quote challenged religious slaveholders that, "To pray and kidnap... are the most preposterous delusion, and the most consummate mocker." Bourne's sarcasm was evident in another as he cried, "Every man who holds slaves, and who pretends to be a Christian or a Republican, is either an incurable idiot who cannot distinguish good from evil." In another Bourne sneered, "If the most guilty and daring transgressor be sought, he is a Gospel Minister, who solemnly avows his belief of the Presbyterian Confession of Faith, or of the Methodist Discipline, and notwithstanding himself is a Negro-Pedlar." ${ }^{\text {It }}$ is no wonder then, that Garrison famously cried, "NO UNION WITH SLAVEHOLDERS!" when faced with the prospect of Texas joining the union as a slave state. ${ }^{7}$

The following year, Garrison began to openly gush about Bourne in the pages of the Liberator. Besides promoting his book, he spoke glowingly of Bourne. When a Georgia editor wrote the Liberator to defend slavery in his state and claim the slaves were their "friends" and "treated as members of our families," Garrison scoffed and suggested the editor either "knows" that his claim was "utterly destitute of truth" or is "insane." Furthermore, Garrison did not feel the need to respond to the Georgia editor. Instead, he said, he "could leave him... in the hands of the Rev. George Bourne." Garrison went on to

${ }^{6}$ Garrison, “Texts on Slavery," The Liberator, December 24, 1831, Issue 52 quoting George Bourne's The Book and Slavery Irreconcilable, 154, 152, 105, 137, 3, 16, 10, 151, 24 in order.

${ }^{7}$ Garrison, “Texas-The Prospect,” The Liberator, Friday, May 24, 1844, pg. 83; Issue 21. 
describe Bourne with high praise and as "one of the most extraordinary men of the age...he resembles Luther—for faithfulness, the apostle Paul—for courage, John Knox— and for zeal, the indefatigable [George] Whitefield." Garrison also touted Bourne as someone who "had to struggle almost singlehanded and endure severe privations." Garrison promised to "extend this panegyric next week" when Bourne would write a column for the Liberator. On another occasion, Garrison compared to Bourne to Benjamin Lay, the Quaker antislavery polemicist, and described Bourne's "remarks on the subject of slavery [as possessing] the impress of a strong mind, and the clearest perception of reason and justice." Garrison clearly admired Bourne, who he called a "veteran abolitionist" and one who spoke "like one having authority...because he comprehends all [of slavery's] abominations, and declares what his own eyes have witnessed, as well as what his ears have heard." ${ }^{8}$ In the two years leading up to December 1833 and the establishment of the American Anti-Slavery Society (AASS), the two men built a conspicuous and mutual respect for one another.

On December 4, 1833 Garrison's and Bourne's mark on the early part of the early years of the abolitionist movement was cemented. Garrison was appointed Foreign Correspondent for the Society while Bourne's book became the manifesto of the movement. The AASS issued a statement styled after the Declaration of Independence. It asserted the natural rights of African Americans and that "every American citizen, who retains a human being in involuntary bondage, is [according to Scripture] [sic] a manstealer." The statement also demanded "that slaves ought to instantly be set free, and

\footnotetext{
${ }^{8}$ Garrison, "Controversial," The Liberator, March 3, 1832, pg. 35, Issue 11; Garrison, "The Rev. George Bourne," The Liberator, Saturday, August 25, 1832; Garrison, "Rev. George Bourne," The Liberator, Saturday, November 16, 1833, pg. 182, Issue 46.
} 
brought under the protection of law." The AASS wanted to address Methodists and Presbyterians and all Christians in the United States. As such, they saw fit to appoint a committee of three that included Bourne, Garrison and Charles W. Denison to prepare a summary of John Wesley's Thoughts on Slavery along with the controversial note on slavery in the Presbyterian catechism which Bourne had invoked during his 1812 trial before the Presbyterian General Assembly. Bourne complied with this request by gathering the information and publishing it the following year with a reissue of his The Book and Slavery Irreconcilable — renamed Picture of Slavery. Bourne simply added vignettes of slavery that he witnessed in Virginia to his 1816 book and bolstered his biblical doctrine of immediate abolition of slavery. All this was published with the full sanction of the Society. ${ }^{9}$

The Society also accepted a motion by Garrison that had far reaching effects on the early years of the American abolitionist movement and signaled his desire to replicate the success of the British abolitionist movement. Garrison sought to involve women in abolition on a large scale and influenced the AASS to reach out to women. Citing the "one million of their colored sisters pining in abject servitude" and "the exertions of the females of Great Britain" who had "been signally instrumental in liberating eight hundred thousand slaves in the Colonies," they invited the women to form societies "in every state, county and town in the Union." And, they encouraged the women to "publish tracts and addresses calculated to wake up a slumbering nation.” If Garrison wanted to produce tracts and pamphlets that were specifically "calculated" to awaken the masses, he

\footnotetext{
${ }^{9}$ Garrison, “Anti-Slavery Convention,” The Liberator, Saturday, December 21, 1833, pg. 102, Issue 51.
} 
engaged just the right person in Bourne to write them. Bourne's immediate publication the very next year, Picture of Slavery, reviewed the most shocking aspects of American slavery witnessed by him in Virginia, and combined them with his brand of biting biblical commentary. ${ }^{10}$ Bourne highlighted the plight of women, whether beaten while pregnant, or groomed for concubinage or even being weighed and sold by the pound. $\mathrm{He}$ described the facts of the maltreatment of women in the South and how that maltreatment violated God's law. The accounts had a particularly shocking effect on readersespecially women, and were enough to galvanize them to join not just a movement, but what they might consider a moral crusade.

Garrison spent a lot of time engaging women in the abolitionist movement and enlisted Bourne's talents in that regard. There is scholarship that tracks Garrison's efforts to include women in the immediatist movement. ${ }^{11}$ It is evident that Garrison and Bourne produced the very tracts "calculated to wake up" and sharpen an army of women who were ready to take the cause of their oppressed sisters in bondage. Besides his Picture of Slavery in 1833, Bourne also published two more books in four years that were targeted to women: The Abrogation of the Seventh Commandment (1835) and Slavery Illustrated in its Effects Upon Women (1837). Each book made a specific appeal to women and demonstrated how American slavery had a damaging effect on marriage, family and the

${ }^{10}$ Ibid.

${ }^{11}$ Lois A. Brown, "William Lloyd Garrison and Emancipatory Feminism in Nineteenth-Century America," In William Lloyd Garrison at Two Hundred, edited by STEWART JAMES BREWER, 41-76, Yale University Press, 2008, http://www.jstor.org.ezproxy.fiu.edu/stable/j.ctt1np71c.6, accessed 4/3/17, 41-72. 
sanctity of womanly virtue and urged women to arise and defend the rights of their African American sisters victimized by slavery.

Female abolitionist societies responded to the gospel call to crusade for their sisters in bondage and they did so on the premise that American slavery was a sin against God, was crime infested, produced untold misery, made the nation likely to come under divine retribution and ought to be immediately abolished. They noted that their sisters' bodies were subject to being commodified and "trafficked," were without the protection of "law or manly shame," and subjected to "merciless stripes" and "cruel outrages." Furthermore, they objected to "the sudden and cruel sundering of the most sacred relations of domestic life." In other words, they resented how American slavery destroyed the lives and families of their sisters in bondage and they saw it as their Christian duty to labor on their behalf. Female societies sprang up in Boston, New York and Philadelphia with like language in their constitutions and literature. ${ }^{12}$

Bourne's biblical writings painted a picture for women that provoked a response among women against American slavery. He sought to show that the treatment of women and their families was harsh, immoral and in violation of the Bible. And if the institution infringed on God's law, it was subject to divine retribution. This argument resonated with women as is reflected by the constitutions and literature of their societies. In his Slavery An Abrogation of the Seventh Commandment (1835) he sought to demonstrate that American slavery as a system stood athwart to the commands of God regarding marriage

\footnotetext{
12 "Preamble to the Constitution of the Boston Female Anti-Slavery Society" on Society for the Study of American Women Writers on http://www.lehigh.edu/ dek7/SSAWW/writBoston\%20FASS.htm, (accessed March 22, 2017); "Preamble and Constitution of the Female Anti-Slavery Society of Chatham Street Chapel" on Abolitionism and the Cult of True Womanhood on https://femaleabolitionism.voices.wooster.edu/documents/document-5/, (accessed March22, 2017).
} 
and family. By its execution, American slavery established exploitive sexual norms that violated the seventh commandment against adultery. The marriages of the enslaved were neither recognized or respected. As such, simple commands having to do with the sanctity of marriage were disregarded for the sake of the domestic slave trade, the masters' sexual predilections and the concubinage of enslaved women. Such conditions made it impossible for the enslaved to build and protect their marriages and families. In his Slavery and its Effects on Women (1837) Bourne probed the depths of American slavery to unearth its depravity.

As women established female antislavery societies, Bourne continued to stoke their activism with pointed commentary. The very next year he was at it again, this time accusing American slavery of systematically violating the seventh commandment concerning the sanctity of marriage and the prohibition of adultery. In his 1834 tract titled The Abrogation of the Seventh Commandment, Bourne blamed women of the South for the existence of American slavery. ${ }^{13}$ He was convinced that "had American females come forward in all the mightiness of their legitimate and resistless influence and demanded the extirpation of that complicated iniquity" the system now known as "American Slavery" would have been used only to express a dead monster, loathed amid universal execration." Bourne believed that to challenge and motivate women to act against American slavery, he needed "to illustrate the operation of slavery in reference to females, in domestic and social life, and in professedly Christian relations." He decried that besides "all the other most odious and criminal attributes of American slaveholding,"

\footnotetext{
${ }^{13}$ George Bourne, The abrogation of the Seventh commandment, by the American churches, New-York, 1835, 3, Slavery and Anti-Slavery, Gale, Florida International University (accessed April 3, 2017).
} 
within the system "a licentiousness of intercourse between the sexes, constant, incestuous, and universal, exists." Bourne saw a system that defied description, the sum of which contained "aggravated corruptions of which, no pen can describe, and no unpolluted imagination conceives." He lamented that this "direful calamity is $[\ldots]$ the very heart's blood of that debasing bondage in which the colored women are held, and by which they are defiled and destroyed." Bourne urged his readers to "grasp at once all the hideous and awful deformity and wickedness of slave-holding in this Republic" as enslaved women were "kept in ignorance, and compelled to live without God, and die without hope, by a people professing to reverence the obligations of Christianity" while they are "ever subject to violation in the most flagrant forms of turpitude, without the possibility of complaint or redress." 14

Enslaved women were easy targets for sexual exploitation in the southern slavery and they were victimized in every way imaginable and their victimization violated not only their bodies, but the scriptures. Bourne offered a list of the variety of ways and proofs that enslaved women were being victimized in the South in violation of scripture. He pointed to "the increasing multitude of the mixed people, who by their diversity of color, American features, and physical conformation, betray their parental origin, [and] incontestably demonstrate the wide spread and incessant licentiousness of the white population." He decried the inability of the enslaved women to "offer any resistance to the attempts of their master, when they choose to coerce them to submission, or to wheedle them into compliance with their lascivious inclination," and he lamented that "there is no law to preserve them, and no protecting authority to which they can appeal."

\footnotetext{
${ }^{14}$ Bourne, Abrogation, 3-4.
} 
He charged that planters grew more than cash crops as a "vast number of persons in Maryland and Virginia now riot [live] in splendor and luxury, solely through the increase and traffic of slaves. Many plantations are equally devoted to the rearing of slaves, as a Northern farm is set apart for the products of a dairy or of grain." And he vehemently rebuked the blatant disregard for marriage in the enslaved community and the attack on the African American family. He charged that "The matrimonial connection among the slaves is altogether nullified. There are fathers, mothers, and children, but there are no families!" He placed much blame on the church for having "fostered and prolonged the curse of slavery in the United States," believing that slavery's eradication could only be achieved "by gospel principles" and "by regenerating the temple of Jehovah" which had by now, in Bourne's estimation, become a "den of thieves and adulterers." 15

It was impossible for white women in the south to be completely unaware of how enslaved women were being victimized. As a result, they came under Bourne's harsh criticism. Far from being gentle southern belles, he declared that if it were known how they referred to their so called "colored wenches" they would be denied entrance to the churches in the north; and if it became public knowledge how severely they "scourge and lacerate their slaves" they would be "discarded" from the churches in New England "as monsters." Bourne, accused that they behaved toward the enslaved Africans with "hard heartedness" and exhibited behavior that violated "every principle of feminine sensibility, and Christian morals and philanthropy." Their behavior deserved, in Bourne's estimation, "the indignant denunciations of the gospel, in all their most pungent and strictly

\footnotetext{
${ }^{15}$ Ibid., 6 .
} 
individualized application." He wondered how white women of the South could feign ignorance of the sexual escapades of the men on the plantation when the evidence of mixed-raced enslaved Africans walked about in plain sight. He rhetorically asked if northern women would tolerate "the spurious offspring of their own husbands, brothers, sons, borne under their own eyes by their constant female attendants [...]."

Divine retribution for slavery was a foregone conclusion for Bourne who believed that even the white women of the south suspected it would come sooner or later. Bourne warned that the women of the south were in fact mortgaging their moral futures hoping "emancipation and retribution will not arrive in their time, and transfer to their daughters and granddaughters the agonies which they are assured await their posterity, unless slavery shall be swept from our Republic." Thus, he urged for women to rise against American slavery in the "authority of Christian principles [...] to demand the immediate and total abolition of that nefarious domestic servitude, which fills every Southern state with all diversified ungodliness and anguish." He maintained that because of the sexual permissiveness of slaveholders regarding their slaves, the Northern churches were bound to adhere to the scripture in 1 Corinthians 5:9-13 that urged adherents, "Not to company with fornicators." He chided northern women for tolerating "preachers who allowed illicit sexual activity between slave owners and slaves." 17

The variegated levels of sexual exploitation violated the chief biblical command against adultery. The Ten Commandments which contained the command against adultery was routinely violated by American slavery and Bourne bore witness. He

\footnotetext{
${ }^{16}$ Ibid., $7-8$

${ }^{17}$ Ibid., 8-10.
} 
lamented that American slavery encouraged the routine violation of the seventh commandment by both white American owners and even enslaved Africans who were at the mercy of their masters. White married owners, for their part, could routinely partake in the violation of their female slaves without their personal character being impugned. "All white men can habitually violate their nuptial vows," Bourne charged, "and the laws of chastity, if they please, without forfeiting their moral or Christian character; because the enactments of slavery preclude the proof, and consequently that disgrace which conviction of the fact might produce." Enslaved Africans, who because of the domestic slave trade were forced to separate from their wives and never to see them again, were thus forced into a subsequent relationship that led to a moral dilemma for the enslaved. Though their marriages were not recognized by American law, Bourne maintained that before God, whose laws he maintained superseded American laws, the slaves were in fact married, and could not be separated. Bourne averred that all marriages were sacred. "A necessary consequence of slavery," Bourne lamented, "is the absence of the marriage relation. No slave can commit bigamy, because the [American] law knows no more of the marriage of slaves, than it does of the marriage of brutes. A slave, indeed, may be formally married, but, so far as legal rights and obligations are concerned, it is an idle ceremony. His wife at any moment may be legally taken from him and sold in the market. The slave laws utterly nullify the injunction of the Supreme Lawgiver- 'What God hath joined together, let no man put asunder."'18

\footnotetext{
${ }^{18}$ Ibid., 11; Bourne quotes a Mr. Jay’s “Inquiry,” 10; Matthew 19:6.
} 
Sexual promiscuity was a key part of American slavery according to Bourne. He made the case and provided scriptural references to support his argument. Bourne argued that "promiscuous licentiousness of intercourse is not a morbid excrescence which has unnaturally been engrafted upon the tree of slavery," instead, he continued, "it is the very sap which gives life, vigour, and perpetuity to the whole system.. ${ }^{19}$ He quoted scripture.

They have cast lots for my people; and have given a boy for a harlot, and sold a girl for wine, that they might drink,'- - but they also practice the transgressions for which the Lord threatens; 'I will not turn away punishment thereof: because they sold the righteous for silver, and the poor for a pair of shoes; that pant after the dust of the earth on the head of the poor, and turn aside the way of the meek: and a man and his father will go unto the same maid, to profane my holy name:' Amos ii. 6,7. ${ }^{20}$

On this point, his argument might strike some as an overreach. It would also seem that it is enough to allege that sexual promiscuity and immorality were embedded in a system that dehumanized and commodified enslaved women. To extend the argument to allege that the driving force for the system was sexual is an assertive one. It is a point, however, that agrees with the argument of a few current scholars concerning American slavery. ${ }^{21}$ Other scholars have also presented evidence that breeding was a large part of the system known as American slavery. ${ }^{22}$

\footnotetext{
${ }^{19}$ Ibid., 13.

${ }^{20}$ Ibid.

${ }^{21}$ Baptist, The Half has never been told, 217-217, 233-244, 305, 359; Barbara Seyda and Nicholas Wright, Celia, a Slave (New Haven: Yale University Press, 2016); Michael Tadman, "The Interregional Slave Trade of the U.S. South," in Walter Johnson, ed., The Chattel Principle, 126.

${ }^{22}$ Gregory D. Smithers, Slave Breeding: Sex, Violence, and Memory in African American History (Gainesville: University Press of Florida, 2012); Michael Tadman, Speculators and Slaves: Masters,
} 
While Bourne accused southern women of being compliant with southern slavery, two southern women proved to be the exception. Sarah and Angelina Grimké they agonized over the institution, and like the oppressed, even daydreamed of freedom in the North. White women of a slaveholding family in South Carolina, they were constantly in anguish over the injustice they saw and heard. They were torn because to run to the North would require them to tear away from loved ones, family and friends. But an overwhelming sense of duty compelled them to speak out against a system that constantly allowed "the oppressor to stand on the neck of the Slave." Sarah had decided early in life that she hated slavery while Angelina was constantly haunted and tormented by horrid scenes she witnessed from childhood growing up in "the house of Bondage." And Angelina knew that if she spoke out there in Charleston she would lose her friends and families. Yet she had an overwhelming sense that God had called her and was preparing her for some "usefulness to [the slaves]." After moving to the North, Angelina and her sister Sarah decided it was time to unburden their souls and put to pen an appeal to their relatives and friends down South regarding what they believed the Bible had to say about their most peculiar institution. They wrote not only to the ones who knew them, they wrote to clergy and women of the South in general out of a conviction that American slavery was a sin. Angelina Grimké was willing to declare to her sisters in the South that, "It will be, and that very soon, clearly perceived and fully acknowledged by all the

Traders, and Slaves in the Old South (Madison, Wis: University of Wisconsin Press, 1989), 122, chapters 6 and 8. Daina Ramey Berry, The Price for Their Pound of Flesh: The Value of the Enslaved from Womb to Grave in the Building of a Nation (Boston: Beacon Press 2017). 
virtuous and the candid that in principle it is as sinful to hold a human being in bondage who has been born in Carolina, as one who has been born in Africa." Now she and Sarah were ready to use the Declaration of Independence and the Bible to "test" the slavery. ${ }^{23}$

Sarah and Angelina Grimké were born in 1792 and 1805 respectively in

Charleston, South Carolina. The daughters of influential slave owners, they grew up in all the wealth and comforts that owning slaves afforded them and their family. Their father, John, was a South Carolina Supreme Court judge and their brothers were influential in Charleston public life. The Grimké sisters, however, felt uncomfortable in their family that lived in a world rife with codes designed to keep African Americans in ignorance and deep bondage. Sarah chafed under the laws and family mores that forbade the teaching of the enslaved how to read and secretly flouted them by teaching her personal slave how to read. When her father discovered that Sarah had taught their slave how to read he was furious; but despite his fury, Sarah was unbowed and by then had already rejected the system that taught her not to teach her slave to read — even if it meant going against her parents and family. Her younger sister, Angelina, never felt close to her mother. She constantly complained that her mother was "cold" and indifferent. If anyone supplied what was lacking from her relationship with her mother, it was her sister Sarah, who became her godmother, lifelong companion and an equally outspoken partner in antislavery for years to come. ${ }^{24}$

${ }^{23}$ Angelina Emily Grimké, Appeal to the Christian women of the South [s.l.], [1836?], 1-2, Slavery and Anti-Slavery, Gale, Florida International University (accessed April 3, 2017); Gerda Lerner, The Grimké Sisters from South Carolina: Pioneers for Women's Rights and Abolition (Chapel Hill: The University of North Carolina Press, 2004), 11-19.

${ }^{24}$ Ibid. 
Sarah set the example in 1835 for her younger sister Angelina in opposing American slavery by publishing "An Epistle to the Clergy of the Southern States.” As the title states, she addressed leaders of churches in the South. Her hope was to "soften the hearts of all, who hold their fellow men in bondage. She was straightforward in her concern about how their "interpretation of the Word of God induced thousands and tens of thousands to receive as truth, sanctioned by the authority of Heaven, the oft repeated declaration that slavery, American slavery, stamped as it is with all its infinity of horrors, bears upon it the signet of that God whose name is Love?" She understood, therefore, that the southern slaveholders had used the Bible as the authority to sanction American slavery. This notion jarred her understanding that God was the embodiment of love. Furthermore, God, Sarah argued, had from the very beginning endowed all men with his likeness and with authority over the earth. This dispensation, she argued, extended to all men, including Africans. Sarah charged that American slavery reduced enslaved African Americans to "a thing." As such, American slavery was at odds with "God's unchangeable decree" and deprived the enslaved of his "inalienable rights" that were rightfully his from the very beginning. She quoted Genesis 1 to make her point: "Let us make man in OUR IMAGE, after our likeness, and let them have dominion over the fish of the sea, and over the fowl of the air, and over the cattle, and over all the earth, and over every creeping thing, that creepeth upon the earth [sic]." Sarah lamented what American slavery had done to the enslaved:

He was created a little lower than the angels, crowned with glory and honor, and designed to be God's vicegerent upon the earth - but slavery has wrested the scepter of dominion from his hand, slavery has seized with an iron grasp this God-like being, and torn the crown from his head. Slavery has disrobed him of 
royalty, put on him the collar and the chain, and trampled the image of God in the dust. $^{25}$

Sarah argued that God "renewed" that mandate about man after Noah came out of the ark after the Flood. Man, according to Sarah, was given "authority" over creation and his right to his own life was to held inviolable by God who held all men accountable for the shedding of human blood. She again quoted Genesis:

And God said, 'And surely your blood of your lives will I require, at the hand of every beast will I require it, and at the hand of man, at the hand of every man's brother will I require the life of man. Whoso sheddeth man's blood, by man shall his blood be shed, for in the image of God made he man.' 26

It is on this point that Sarah warned that South faced the strong possibility of divine retribution. She made the distinction between humans and animals and what the law said about shedding the blood of animals and human blood but quoting a familiar scripture:

This distinction between men and things," Sarah explained, "is marked with equal care and solemnly under the Jewish dispensation. 'If a man steal an ox, or a sheep, and kill it, or sell it, he shall restore five oxen for an ox, and four sheep for a sheep.' But 'he that stealeth a man and selleth him or if he be found in his hand, he shall surely be put to death.'27

From this scripture Sarah extended the argument by asking a searching question: What would happen "If this law were carried into effect now, what must be the inevitable doom of all those who now hold man as property?" Sarah declared that the South had placed itself at risk of divine retribution for holding in bondage those who were made in God's likeness.

\footnotetext{
${ }^{25}$ Sarah Moore Grimké, An epistle to the clergy of the southern states, [New York], [1836?], 1-2, Slavery and Anti-Slavery, Gale, Florida International University (accessed April 3, 2017). 
Sarah not only believed that the Africans were made in God's likeness and that their blood was precious in his sight, she argued that they were Christ's brothers. She averred that Christ had come into the world to die for all mankind and that in dying for them, he called them brothers. This included the Africans. Sarah explained to the clergy that, "Christ Jesus, wearing our form and dying for our sins, thus conferring everlasting honor upon man by declaring "both he that sanctifieth and they who are sanctified are all of one: for which cause he is not ashamed to call them brethren." Based on this scripture, Sarah lamented that the South had unwittingly enslaved Christ's brothers. "It is then," Sarah cried, "the Lord's brethren whom we have enslaved; the Lord's brethren of whom we say 'slaves shall be deemed, taken, reputed, and adjudged, chattels personal in the hands of their owners and possessors to all intents and purposes whatever.'-Laws of South Carolina. [sic]" She further maintained that the laws of South Carolina could not "annul" the laws of God nor could they "sanctify" oppression legal in his sight. She further maintained that Christ would say to "our guilty country" that they should "Do unto others as ye would they should do unto you." 28

Sarah denied that American slavery had any biblical basis for its existence. She maintained that "Jewish servitude, as permitted by God, was as different from American slavery, as Christianity is from heathenism." She averred that while the scriptures "prohibited cruelty and oppression" the slave states maintained that "the master may, at his discretion, inflict any species of punishment upon the person of his slave" while the

${ }^{28}$ Ibid., 5-6. 
laws of South Carolina further protected the masters by not allowing a slave to testify against their masters. She asserted that the Hebrew language did not contain a word in its vocabulary that was "equivalent to slave." The word used, "obed," could be used interchangeably to mean "bond servants and hired, to kings and prophets, and even to the Saviour of the world." As examples of languages and culture that had no word for a concept that the culture could not conceive of, she provided the Burmese who had no concept of eternity so they did not have the word in their vocabulary; or the Greeks or Romans who had no word equivalent to humility, "because they acknowledged no such virtue." As such, she further attested that "the want of any term therefore in the Hebrew, to mark the distinction between a slave in the proper sense of the term and other servants, is proof presumptive to say the least, that no such condition as that of slave was known among the Jews of that day." 29

To those who justified slavery based on Abraham owning slaves, Sarah categorically rejected such assertions. "To assert that Abraham held slaves is a mere slander." Sarah maintained that Abraham's "servants" gathered around him "voluntarily" and that Abraham held no one in bondage. "Would he have been called from a heathen land to be the father of the faithful in all generations, that he might enslave the converts he made from idolatry?" Sarah answered her own question with a resounding "No" and further asserted that "from the confidence which Abraham reposed in his servants we cannot avoid the inference that they clustered voluntarily around him as the benefactor of their souls" and as their "patriarch." It would seem on this point she could have further

\footnotetext{
${ }^{29}$ Ibid., 6-7.
} 
asserted that there is no record of any of his "servants" were bound by chains or that Abraham hunted any of them down as was done in the South. ${ }^{30}$

To those southern preachers who maintained that southern slaveholders were merely fulfilling prophesy holding Africans in bondage, Sarah maintained that this did not exculpate their crimes against the Africans. She provided two examples as warnings. She retold the story in Genesis 15 in which God predicted for Abraham what would happen to his descendants in Egypt for 400 years. Sarah explained that though what happened came to pass, this did not excuse Egypt and Pharaoh the divine retribution that came in the form of plagues. She also related the story of how the Jews were held accountable for the crucifixion of Christ although his death for the sins of the world was predicted through Old Testament prophesies. The South could therefore not claim ignorance since the Egyptians and the Jews were held accountable for their oppressions. ${ }^{31}$

To those who maintained that Christ never condemned slavery, Sarah maintained that Christ condemned the Pharisees for less. "We have added a deeper shade to their guilt," Sarah lamented. She maintained that while Christ rebuked the Pharisees as such, "Wo unto you, Scribes and Pharisees, hypocrites! for ye devour widow's houses, and for a pretence make long prayers, therefore ye shall receive the greater damnation [...]" Meanwhile, Sarah accused the southern slaveholders who "make widows by tearing from the victims of a cruel bondage, the husbands of their bosoms, and then devour the widow herself by robbing her of her freedom, and reducing her to the level of a brute." Though she did not, she could have easily added that the widow was robbed of her offspring due

\footnotetext{
${ }^{30}$ Ibid., 7.

${ }^{31}$ Ibid., 8-9.
} 
to the domestic slave trade. Sarah maintained, therefore, that American slavery was worse than even the crimes committed by the Pharisees whom Christ excoriated and she warned the southern clergy to join her in the movement to redress American slavery. "We entreat the Christian ministry," Sarah cried, "to co-operate with us to unite in our petitions to Almighty God to deliver our land from blood guiltiness; to enable us to see the abominations of American slavery by the light of the gospel." She believed that it was impossible to support American slavery and hold to the "whole counsel of God." For someone to defend and support slavery, they must according to Sarah, ignore scriptures like one in James which asserted, "Behold the hire of hour laborers which is of you kept back by fraud crieth, and the cries of them which have reaped, are entered into the ears of the Lord of Sabaoth." Moreover, to support American slavery "multitudes of other texts must be virtually expunged from the Bible of the slave holding minister; every denunciation against oppression strikes at the root of slavery." Therefore, Sarah warned her southern brethren that "'The Lord said I have surely seen the affliction of my people, and have heard their cry by reason of their task-masters, for I know their sorrows."” As such she declared that God "knows the sorrows of the American slave, and he will come down in mercy, or in judgement to deliver them." 32 In this way, Sarah agreed with Maria Stewart that God "heard the cry" of his people, the enslaved Africans.

The following year Sarah's younger sister, Angelina, tried her hand at addressing slaveholders in the South. Like her sister, she cared deeply about her relationship with God and was given to keen self-examination and reflection. Her thoughts, as expressed in her diary, reflect a young woman who desired to be all she could be for God. Angelina

\footnotetext{
32 Ibid., 10-12.
} 
was uncomfortable with slavery growing up. The maltreatment she witnessed bothered her and when she was given a personal slave to manage, she rationalized her acceptance of the responsibility as a way protect the young slave from harm from others. As she approached her twenties, however, she began to make a clean break with slavery, her hometown and even her family. She believed that the Bible and the Gospel condemned what she witnessed in Charleston insofar as the treatment the enslaved. She believed the Golden Rule made it impossible to hold men and women in bondage. Increasingly she engaged in debates with family and friends about their stance on slavery and was loudly opinionated with her biblical convictions. In the light of the Golden Rule to "do unto others as they would have done unto them," Angelina often challenged family members if they themselves were willing to subject themselves to the same treatment and bondage they subjected their slaves. But beyond engaging in debate, she felt unable to do more for the slaves than to "weep" in solitude. She was now relieved she could address the issue with a direct appeal to her sisters to the south without immediate repercussion.

Long viewed in the North as a sin and abolished, the international slave trade had now also lost favor in the South in favor of the domestic slave trade. Angelina therefore addressed the southern "sophistry" that made it a sin to participate in the now illegal international African slave trade while holding in bondage their descendants born in America. She insisted that the Declaration of Independence applied to the enslaved African Americans as equally as it did to white Americans. And she believed that the forefathers were with her on that point. "We must come back," Angelina declared, "to the good old doctrine of our forefathers who declared to the world, 'this evident truth that all men are created equal, and that they have certain inalienable rights among which are life, 
liberty, and the pursuit of happiness." 33 She found it even more "absurd" to think a man, no matter their color, could be born in what was ostensibly a "free Republican

Government" be born a slave and yet free in the supposed "despotisms of barbarian Africa." ${ }^{\prime 34}$ The two did not equate. Angelina declared:

If then, we have no right to enslave an African, surely we can have none to enslave an American; if it is a self evident truth that all men, every where and of every color are born equal, and have an inalienable right to liberty, then it is equally true that no man can be born a slave, no man can every rightfully reduced to involuntary bondage and held as a slave, however fair may be the claim of his master or mistress through wills and title-deeds. ${ }^{35}$

By invoking the Declaration of Independence, Grimké joined the ranks of immediatist abolitionists. But she quickly pivoted to her "highest authority," the Bible. ${ }^{36}$

Angelina, like many in the South, revered the Bible as her ultimate authority.

"Now," she exclaimed, "the Bible is my ultimate appeal in all matters of faith and practice, and it is to this test I am anxious to bring the subject at issue between us." With that she began her argument that all men, including Africans, were born free, with an invocation of Adam. Angelina maintained, like Sarah, that God had ordained man to have "dominion over the fish and sea... and over every living thing that moveth upon the earth." She reiterated this by quoting the eighth Psalm in which the psalmist wrote that God had "madest him [man] to have dominion over the works of thy hands; thou hast put

\footnotetext{
${ }^{33}$ Ibid, 2.

${ }^{34}$ Ibid.

${ }^{35}$ Ibid, 2-3.

${ }^{36}$ Ibid, 3.
} 
all things under his feet." Angelina made these allusions to make the point that man was given a mandate over God's creation and "things" made by the hand of God. Likewise, man was never given a "charter" to rule over other men as "things." As such, the enslaved Africans, who had been reduced to that status of "things" and "a chattel personal" by American slavery in the South, were done so against the will of God. "Man, then, I assert," Grimké declared, "never was put under the feet of man, by that first charter of human rights which was given by God, to the Fathers of the Antediluvian and Postdiluvian worlds, therefore this doctrine of equality is based on the Bible." ${ }^{37}$

In anticipation of those who would use the so-called Curse of Ham described early in Genesis, Angelina equivocated as to whether that curse was limited to Canaan and extended to "all the children of Ham." But she was adamant in her belief that the prophecy was not of what "ought to happen" but what perhaps "actually" happen. As such, to "justify America for enslaving the children of Africa, we must also justify Egypt for reducing the children of Israel to, for the latter was foretold as explicitly as the former." Angelina went on to explain that just because something was prophesied did not mean that it would not be condemned by God. She quoted Jesus on the subject. "Hear what our Saviour says on this subject; 'it must needs be that offences come, but woe unto that man through whom they come." She also referenced the prophesies concerning the crucifixion of Christ and the subsequent of the guilt of those who partook in his execution. For this point, she quoted the Apostle Peter: "[Jesus] being delivered by the determinate counsel and foreknowledge of God, ye have taken, and by wicked hands

\footnotetext{
${ }^{37}$ Ibid.
} 
have crucified and slain." On this point, it is noteworthy, and Grimké does not make the point, that those who Peter addressed were "cut to the heart" when they heard Peter's words accusing them of executing Jesus Christ. ${ }^{38}$ In other words, Grimké's argument was that just because something might be predicted in the Bible, such predictions cannot be used as exculpatory evidence to acquit the collective slaveholding South.

Angelina also addressed the paternalistic arguments employed by the South who maintained that Abraham held slaves so therefore slavery must be sanctioned by the Bible. On this point an incredulous Angelina asked the South a probing question: "Do you really believe that partriarchal servitude was like American slavery? Can you really believe it?" All they had to do was read their Bible, she believed, to be cured of any comparisons between American and that of the patriarchs. Abraham and Sara served as her examples of how unlike the patriarchal system of servitude differed from American slavery. Grimké pointed out how Abraham and Sarah both performed what could be considered menial tasks usually reserved for servants. Grimké, the daughter of slave owners defied anyone to provide examples of any southern slave owners who themselves cooked or baked food "with their own hands" for guests as Abraham and Sarah had done as recorded in Genesis. Then she asked the obvious question: "If the servants they had were like Southern slaves, would they have performed such comparatively menial offices for themselves?" Grimké further contrasted Abraham's view of his servants and his intent to appoint one an heir of his estate while he still found himself to be without a son who could be his heir. Grimké made the application to American slavery: "Is this like Southern slavery? I leave it to your good sense and candor to decide.” On the issue of

\footnotetext{
${ }^{38}$ Ibid, 4; Acts 2:36-37.
} 
bearing arms, Grimké made this contrast with American slavery: Besides, such was the footing upon which was with his servants, that he trusted them arms. Are slaveholders willing to put swords and pistols into the hands of their slaves?" Grimké even attacked the whole notion of a paternalistic form of slavery in the south. "[Abraham] was as a father among his servants; what are planters and masters among theirs?" It is here that she questioned the slavery she grew up with. While proslavery apologists claimed that theirs was a paternalistic slave society, Angelina, a woman who grew up in a slave owning family and culture, denied that the system of slavery she grew up observing was anything like the one she read about in the Bible. ${ }^{39}$

Besides denying that American slavery was paternalistic, Angelina denied that slave owners were even concerned about the moral development of their slaves. And again, it was on this point that Angelina painted a stark contrast between American slave owners with Abraham and his servants. She cited the directive from God to Abraham in Genesis to circumcise every member of his household, including his servants, and to "command his children and his household after him, and they shall keep the way of the Lord to do justice and judgment." Here Angelina posed a question to her sisters in the south she already knew the answer to:

Now my dear friends many of you believe that circumcision has been superseded by baptism in the Church; Are you careful to have all that are born in your house or bought with money of any stranger, baptized? Are you as faithful as Abraham to command your household to keep the way of the Lord? I leave it to your own consciences to decide. Was patriarchal servitude then like American Slavery? ${ }^{40}$

\footnotetext{
${ }^{39}$ Ibid.

${ }^{40}$ Ibid.
} 
That Angelina stated that she would leave it to their consciences to decide if southern slave owners directed their children and households to "keep the way of the Lord" signals Grimké's level of modesty and restraint in describing the immorality that marked American slavery. It is evident that she did not want to delve into the darkest features of American slavery as others like Bourne were willing to go. That she was unwilling to do so does not mean that she censured abolitionists like Bourne who were willing to go there. In fact, she flatly stated later in her appeal that she read the work of other abolitionists and assured his sisters of their veracity:

I have regularly taken the Liberator, and read many Anti-Slavery pamphlets and papers and books, and can assure you I never have read a single insurrectionary paragraph, and never read any account of cruelty which I could not believe. Southerners may deny the truth of these accounts, but why do they not prove them to be false. Their violent expressions of horror at such accounts being believed, may deceive some, but they cannot deceive me, for I lived too long in the midst of slavery, not to know what slavery is. When I speak of this system, 'I speak that I do know,' and I am not at all afraid to assert, that Anti-Slavery publications have not overdrawn the monstrous features of slavery at all. And many a Southerner knows this as well as I do. ${ }^{41}$

The authority of Angelina's assertion about the "monstrous feature of slavery" lay in the fact that "I lived too long in the midst of slavery," and therefore "I speak that [which] I do know." It bears mentioning here that George Bourne had published his Picture of Slavery which described what he saw of slavery in Virginia. It is not a stretch to assume that Grimké was familiar with Bourne even though she does not mention him. And she

${ }^{41}$ Ibid, 29. 
asserts that she had read nothing about slavery, presumably even from Bourne, that she "could not believe." 42

While proslavery apologists argued that slavery was permitted under the Mosaic Law Grimké maintained that it was not the same as American slavery. She seeded the point that there was "a species of servitude was permitted to the Jews..." But while allowing the point, she countered by arguing that "the servant was guarded from violence, injustice and wrong." She built her argument by contrasting how Hebrew servants became servants with how African Americans were enslaved. Grimké outlined 6 ways in which Hebrews entered servitude and the corresponding scripture:

1. He sold himself if impoverished-Lev. 25:39

2. A father might sell his daughter with the understanding she would become a wife-Lev. 21:7

3. Those in debt would be sold to pay off their debt -2 Kings 4:1

4. Thieves unable to pay restitution might be sold to pay restitution-Ex. 21:4

5. Born into servitude-Ex. 21:4

6. Sold themselves to a wealthy Gentile-Lev. 25:47-55 $5^{43}$

After outlining the ways in which Hebrews entered servitude, Grimké asked several piercing questions of her readers designed to illustrate the contrast between how the Hebrews entered servitude and African Americans were enslaved. She queried her readers:

I would just ask whether American slaves have become slaves in any of the ways in which he Hebrews became servants. Did they sell themselves into slavery and receive the purchase money into their own hands? No! Did they become insolvent, and by their own imprudence subject themselves to be sold as slaves?

No! Did they steal the property of another, and were they sold to make restitution

$$
\begin{aligned}
& { }^{42} \text { Ibid. } \\
& { }^{43} \text { Ibid, } 5 .
\end{aligned}
$$


for their crimes? No! Were they born in slavery? No! No! not according to Jewish Law, for the servants who were born in servitude among them, were born of parents who had sold themselves for six years: Ex. xxi, 4. Were the female slaves of the South sold by their fathers? How shall I answer this question? ${ }^{44}$

It is instructive to observe that Angelina maintained that African Americans should be considered as Hebrews because they were born in the U.S. and ought to be considered citizens. It is also worthy of observation that it is here where she must be very delicate in how she answered the last question, since the issue of "fathers and their daughters" in American slavery was a doubled edged sword. If the father of the female slave was a slave himself, then the answer to the question was of one sort. But if the father of the female slave was the plantation owner himself due to a miscegenous and sexually exploitive relationship, the possibilities grew darker, indelicate and too sinister a topic for Grimké to address with her audience. First a look at the former possibility and its inherent injustice:

They [enslaved father and daughter] labor day by day, and year by year, side by side, in the same field, if haply [sic] their daughters are permitted to remain on the same plantation with them, instead of being as they often are separated from their parents and sold into distant states, never again to meet on earth. ${ }^{45}$

Here Grimké points out that the father, a slave, has no agency to direct the affairs of his home. That power rested with the plantation owner who could separate the father's family by selling the daughter to parts unknown, never to be seen by her family again.

The latter possibility was much harder for Grimké to articulate as a $19^{\text {th }}$ century Southern woman. While other male abolitionists freely discussed the sexually exploitive nature of American slavery, Angelina found herself unable to pen the sexual horrors

\footnotetext{
${ }^{44} \mathrm{Ibid}$.

${ }^{45}$ Ibid.
} 
visited on enslaved females. Just the thought seemed to make her tremble and content to leave it to the imagination of the reader:

But do the fathers of the South ever sell their daughters? My heart beats, and my hand trembles, as I write the awful affirmative, Yes! The fathers of this Christian land often sell their daughters, not as Jewish parents did, to be wives and daughters-in-law of the man who buys them, but to be the abject slaves of petty tyrants and irresponsible masters. Is it not so, my friends? [I] leave it to your own candor to corroborate my assertion. ${ }^{46}$

That Grimké left to her readers' "candor to corroborate [her] assertion" is indication that she is hinting at sexual exploitation of female slaves. Earlier in the paragraph she asserted that fathers of slaves did sell their daughters. What fathers could she have been referring to if it was not the plantation owners who, after fathering enslaved females, sold them not to be wives but to be the previously mentioned "fancy maids."

If Grimké was squeamish about addressing the sexual exploitation of enslaved women, George Bourne was not. In no uncertain terms, and in the same year, he outlined the various ways in which enslaved women and their families were sexually exploited and reduced to "things" by their masters. He had personally observed how American slavery effected women and their families and decided to address the issue specifically to the women abolitionist societies. In his 1837 book titled Slavery Illustrated in its Effects upon Woman and Domestic Society Bourne plumbed the depths of depravity that American slavery descended to and how women, white and black, were damaged by the institution. Bourne focused on six areas affecting enslaved African American women and their white female counterparts: Marriage, the condition of female slaves, the effects of slavery upon domestic relationships, the duty of the slave-holders female relatives, the

\footnotetext{
${ }^{46}$ Ibid, 5-6.
} 
impurity within the Christian Churches and lastly, the duty of Northern Christian Women ${ }^{47}$ From the title page, Bourne wasted little time deploying prophetic scriptures to abjure American slavery, its ancillary domestic slave trade and its incestuous culture:

"They have given a boy for a harlot, and sold a girl for wine, that they might drink!"48

"They sold the righteous for silver, and the poor for a pair of shoes; and turn aside the way of the meek. A man and his father will go in unto the same maid, to profane my holy name!"49

In Slavery Illustrated in its Effects upon Woman and Domestic Society, Bourne cried out to "all the members of female anti-slavery societies" that "those sisters in philanthropy may be stimulated to untiring exertion in behalf of twelve hundred thousand women, who are now chained in the American house of Bondage." He called their plight "the most important theme in the whole controversy upon slavery." He believed that the system of American slavery, the most modern version of slavery, was unprecedented and equally condemned by the Bible. "American slavery is always, in all its modifications, and from beginning to end, condemned by divine revelation. Such a thing as an American slave was unknown to the Israelites and Jews." And he believed it to be "insulting to man and dishonoring to God" to instruct $19^{\text {th }}$ century Christians to first consult century Roman and Greek pagans "to learn their duty as followers and disciples of Jesus, the Lord of all" regarding to slavery. But such "theology," Bourne maintained, could not mask or distract

\footnotetext{
${ }^{47}$ George Bourne, Slavery illustrated in its effects upon women and domestic society, Boston, 1837, iv, Slavery and Anti-Slavery, Gale, Florida International University (accessed April 3, 2017).

${ }^{48}$ Ibid, Title Page.

${ }^{49}$ Ibid.
} 
from what "a Bible-robbing, a man-stealing, a woman-selling, a chain-forging, a marriage-destroying, a slave-manufacturing, and a man-slaying system," American slavery was. Because of the profound impact of American slavery on enslaved women, Bourne appealed to Northern white women to "combine, 'with one heart and soul,' to cast out the Legion of Devils which there dwell.".50

In this book, Bourne sought to lay out the biblical case against American slavery and its devastation on enslaved women and their families. Bourne believed that American slavery was "unscriptural and barbarous" even as it was "unconstitutional as it is unjust" and must be opposed. Bourne also believed American slavery to be unprecedented in history. "No melancholy facts in the annals of human depravity are more direful than the prominent circumstances connected with American slavery.” Beyond the inhumanity and injustice of American slavery, Bourne equally decried the immorality and "profligacy" that American slavery openly displayed and the role it played in ruining families. Furthermore, he arraigned the churches for their complicity in perpetuating its social degeneracy. ${ }^{51}$ Bourne wrote:

American slavery is often condemned as unjust and inhuman; but it is also more pernicious, when considered as the ever-flowing fountain of all uncleanness. That profligacy is not even attempted to be concealed. It is public, notorious, and uncovered as the daylight. Mothers and daughters are acquainted with the flagrant sensuality of their sons and brothers. Wives and daughters are certified of the constant adulterous intercourse of their husbands and fathers. This social degeneracy has been continually increasing, and now is extending itself in an equal ratio with the numerical progression of the slaves. Ministers of the gospel in the southern States know these heaven-daring crimes to be undeniable; and yet by their silence they virtually sanction them. ${ }^{52}$

\footnotetext{
${ }^{50}$ Ibid, vii.

${ }^{51}$ Ibid.

${ }^{52}$ Ibid, 22-23.
} 
Bourne could not think of a time in history where the system of slavery that was American slavery was ever paralleled "either in enormity, or extent, or continuance, to the degradation of the colored women in the United States.."53

The southern churches had long defended the rights of southerners to hold slaves. And while there were exceptions, southern churches, Bourne found, did little to constrain the sexual predilections of their slaveholding members and did little to defend enslaved women. He therefore did not just rebuke the church's complicity with American slavery, he was a strident advocate on behalf of enslaved women as is evident in this next quote:

Despoiled of all protection; exposed to every indignity; obliged to submit to the brutal demand of any lawless white man; coerced to degradation by heartrending tortures; doomed to sacrifice the tenderest affections; scourged to conceal their instinctive sensibilities; and robbed of a husband's love, a father's guardianship, a son's aid, and a brother's endearment; they are merely human tools to pander to the sensuality, and to gratify the unclean desires of their inhuman task-masters. ${ }^{54}$

Bourne mocked the farce on display in the marriage ceremonies that enslaved African Americans pantomimed under the watchful eyes of their owners. "Base and servile preachers" did not exact an oath from the enslaved bride and groom to live together until death did them part, but "'as long as circumstances will permit;"” or, in other words, "until the man-stealer wants money, and can sell one or both of them," Bourne lamented. "And instead of using the Lord's words," Bourne chided, “What God hath joined together, let man not put asunder,' he altogether omits the divine approbation of their

\footnotetext{
${ }^{53}$ Ibid, 26.

${ }^{54}$ Ibid.
} 
union, or substitutes his own adage-What slave-drivers join together, let men-stealers put asunder." 55

Since southern slave holding states maintained that the enslaved were "chattel" and thus property, slave holders could sell their enslaved women to be used in any wayincluding for purely for sexual use. In effect, slave holding states operated legalized prostitution. Bourne maintained that American slavery reduced the slave states to a "vast brothel." He accused the whole of it to contain "multiform incests, polygamy, adultery, and other uncleanness are constantly perpetrated." He suspected "there is not a man, or woman, or boy, or girl, or any who has arrived at the age of puberty, that is not acquainted with nearly the whole mass of abomination." As such, he challenged anyone to prove from scripture how such a system that produced such sexual immorality and the desolation of families could receive biblical sanction. "We defy any man," Bourne challenged, "to adduce from the law, or the prophets, or the psalms, or the evangelists and apostles, one solitary word which justifies the dissolution of the nuptial covenant; and destroys all domestic relations; and necessarily transforms men and women as a creature for defilement without redress or possibility of escape whenever her vile tyrants choose to trample upon the seventh commandment." Bourne called any notion that American slavery, and its legal transformation of a million enslaved women "to be used whenever the men-stealers please, for loathsome intercourse, to be "sanctioned by the bible" as "the father of lies." 56

\footnotetext{
${ }^{55}$ Ibid, 26-27.

${ }^{56}$ Ibid, 27-29.
} 
Such salacious and scandalous accusations were not for the squeamish who charged that they went beyond decorous public discourse. And if they were not leveled by an eye witness they would be unbelievable and outrageous. Yet, this is where such testimony is powerful when delivered by a witness to the facts. And like many runaway slaves who bore witness by virtue of their, autobiographies Bourne, though not a former slave, was an unabashed witness to American slavery by virtue of his living in Virginia for 6 years. To those who charged that Bourne's representation of American slavery was "indecorous and reproachful," his retort was that it was "unimpeachably accurate" and predicted that a "tremendous retribution" would come upon the nation because Bourne, an Evangelical preacher, placed heavy emphasis on the sanctity of marriage and he maintained that the institution of marriage had its origin in the Garden of Eden and was "ratified" by Jesus Christ. He cited Genesis 2:18-24 that describes the relationship of Adam and Eve and he also cited Jesus' words in Matthew 19:3-6 regarding the sanctity of marriage. Furthermore, Bourne argued that "the inspired Apostle," likely Paul, further sanctioned marriage when he wrote, "Let every man have his own wife, and let every woman have her own husband." The sanctity of marriage applied to enslaved African Americans, whom Bourne believed, had the right to expect that their marriages would be respected by everyone. Furthermore, he believed that enslaved women had the right to be "undefiled" and to be "honorably wooed, prior to the sanctified and endeared intercourse of connubial life." Therefore, Bourne decried that "this inestimable attribute which combines the wife's affection, the mother's love, and the sister's tenderness, in all their energetic purity, is entirely eradicated by slavery." ${ }^{, 57}$

\footnotetext{
${ }^{57}$ Ibid, 29-32.
} 
Slave breeding was part and parcel of the chattel slavery that existed in the south. There is research that attests to its existence. And it was an issue that Bourne savagely attacked. He maintained that the enslaved were bred for domestic slave trade that underwrote the opulent Southern lifestyle and the westward expansion of the U.S. "In countless instances, many of the southern families life in sloth and voluptuousness and 'frolic,' solely from the annual sales of the colored people as they arrive at the ordinary age of manhood." Bourne likewise lamented how the breeding of a lighter version of Africans, only served to expand the slave states westward driven by greed. "The trade in 'breeding wenches," Bourne wrote, "and the constant contrivances to diminish the sable color, to augment the number, and to extend the traffic of slaves, are facts notorious as the existence of slavery itself; and every attempt to extend the United States by admitting slave-holding communities into the Commonwealth, is merely expanding the present market for our colored citizens; and directly sanctioning that hell-born system which encourages its adherents to "work all uncleanness with greediness." 58

Regardless of whether or not all enslaved women actually faced sexual harassment, they had no legal recourse to defend themselves from sexual predators, especially if they were owned by the predator. While Bourne tried to qualify his statements to avoid generalizing, he lamented that American law and society stood against enslaved women. He did not believe that all enslaved Africans had been so violated or defiled nor were all white men involved in so violating their enslaved women. But Bourne alleged that the system was rife with incidences in which white men violated and defiled their enslaved women for the purposes of breeding. Furthermore, the

\footnotetext{
${ }^{58}$ Ibid, 38.
} 
legalities that sustained such a system allowed white men the latitude to do as they pleased with their female "property." "There is no law against female violation," Bourne lamented, "and no redress for the injured colored woman. No earthly tribunal exists to which she can appeal." He lamented that in the one place where enslaved women should ostensibly be kept safe and free to protect her chastity, the church, is where she was most at risk at the hands of officers of the church, no less. She would have no recourse and no one to appeal to within or without of the church. "Thus even the colored Christian women," Bourne cried, "with the most delicate virgin modesty and women with the most reserved chastity and faithfulness to their lovers, are almost universally doomed to submit to defilements which they loathe, and to agonies of conscience equally perplexing and full of disquietude; because the civil jurisdiction legalizes their debasement, and the church tacitly sanctifies their habitual pollution and groans.” Bourne therefore believed that enslaved women only had one option for redress: appeal to God. And Bourne believed he would hear and act in the form of divine retribution. Bourne declared:

Their appeal for deliverance can be made to God alone; and however long the Hearer of prayer may delay the answer, yet the prophetic vision is equally applicable in this case, as to myriads of other events in divine Providence. The vision is yet for an appointed time; but at the end it shall speak, and not lie. Though it tarry, wait for it; because it will surely come, it will not tarry. ${ }^{59}$

Slave codes were such that the enslaved could not testify in court. For enslaved women this was doubly troubling because not only were they black, they were women. Bourne, therefore, condemned the legal conditions of female slaves in American slavery. "The whole code of slave legislation," Bourne decried, "is diabolically contrived to admit

\footnotetext{
${ }^{59}$ Ibid, 41-42.
} 
the slave-drivers and the kidnappers to perpetrate their heinous crimes with impunity." Fundamentally speaking, Bourne understood that the system gave absolute power to white men to do as they pleased with enslaved women. "What are the cardinal principles of American slavery?" Bourne rhetorically asked. "Slaves are under the absolute power of their kidnappers; and are deemed to be chattels and personal estate, except in the case of descents, when they are real estate." In American slavery, by law, white men could do as they pleased, even in the church, regardless of the wishes of the enslaved. The enslaved could not enter any legal contract or covenant such as marriage. Much less could they resist a beating or being raped; and if violated, there was no way for the enslaved to sue for redress or damages. Bourne therefore also pointed out how the laws in the southern slave states were diametrically opposed to the biblical rights of the oppressed to expect to be unmolested in their quest for self-emancipation. Speaking of Fugitive slave laws, Bourne pointed out the challenges facing slaves seeking to escape sexual abuse. "The doomed victim of lust cannot ascertain how to escape her pollution and anguish." Bourne lamented, "It is true the law of God enacts, (Deuteronomy xxiii. 15, 16) - 'Thou shalt not deliver unto his master the servant who is escaped from his master unto thee. He shall dwell with thee, among you, in that place which he shall choose, where it liketh him best; thou shalt not oppress him.' But the detestable laws of our country are in direct opposition to the enactment of Jehovah." ${ }^{60}$ By making this point, Bourne tied the oppression of African Americans to the violation of scripture.

${ }^{60}$ Ibid, 45-46. 
The world that northern white women lived in was far and away from the one that enslaved women of the south lived. A bridge needed to be built to connect the polar experiences of the two disparate sets of women. Bourne, therefore, contrasted the plight of enslaved African American women with that of white women. White women could expect that their parents, brothers, extended family, friend and ultimately the law to protect them if they are sexually harassed. Not so with enslaved African-American women. "A young [enslaved] woman," Bourne lamented, "sensitive as feminine modesty can imbue her with decorum, is agonized with constant solicitations voluntarily to abandon herself to her tyrant driver, or his son, or both of them, and intimidated with menaces of their scourging, if she resists their authority and lecherous desires." Enslaved African-American women could also be under duress from a white man who, because he shares the same father being the plantation owner, also happens to be her brother. In such a case the enslaved woman, who did not want to receive his advances had no recourse than to submit or suffer violent lacerations. ${ }^{61}$ Bourne described the incestuous nature of an enslaved woman's sexual exploitation:

Her own brother may be the debauchee who is resolved to violate her. Her sole friend and lover would instantly be murdered by slow-paced tortures if he dared to murmur, much less to oppose the vile design, or if their mutual attachment was only suspected. Complaint to a JUSTICE of the peace would be answered by urging his own claim to the right of carnal knowledge of her, or by commanding the public whippers [sic] to give 'her fifty lashes well laid on." 62

Such were the moral quandaries that enslaved African-American women found themselves in. Escape, being a possibility for enslaved women, presented the risk of

\footnotetext{
${ }^{61}$ Ibid, 46.

${ }^{62}$ Ibid, 46-47.
} 
capture and severe punishment by their masters. Fugitive slave laws - laws Bourne was careful to point out violated scripture, loomed over the cherished dreams of freedom that enslaved women nurtured within their hearts even as they endured "moral anguish" and "a revolting guilt which woman is doomed to suffer." 63

The absurd world of the enslaved women who lived under constant sexual siege had to be plumbed and a variegated picture had to be painted so white women of the north could get a sense of the sexual horrors that their black sisters faced daily. One after another, Bourne shared vignettes of women violated by their unnamed masters who acted with impunity because the law of American slavery protected them. First there was the story of a Virginia legislator who purchased a mulatto female slave to openly live with while he moved his family to another home. The unhappy woman confided in a neighbor that the legislator tried to seduce her. After several unsuccessful attempts the legislator finally resorted to violence and ordered that she be beaten until she succumbed to his sexual advances. In another story, Bourne recounted how a woman was whipped publicly until her skin peeled from her body and the blood flowed. In yet another illustration, he related the occurrence of a man who dragged his enslaved woman for three hours behind his horse and then whipped her while tied to a tree. After the whipping, he went in the house leaving her tied to the tree while he ate and conversed for several hours. Bourne said these scenarios were "the universally habitual course of life among the vast majority of the slave-holders in the southern States." 64 Practices as these left enslaved African American women at the complete mercy of their white male owners.

\footnotetext{
${ }^{63}$ Ibid, 47.

${ }^{64} \mathrm{Ibid}, 48-50,53,53-58$.
} 
Slave owners, according to Bourne, could and would legally decide what to do with their enslaved women's bodies. The effects of their decisions could be felt by the enslaved females at an early age. If they thought best, they could themselves, or their male sons, introduce the young women to intimacy. It was in those sexual encounters with their young female slaves that the "effervescence of lewdness" and the "wantonness of ferocity" were combined; and the "perversion of the most delicate and tender of our emotions" would "degenerate into the most abhorrent impulses." He described a world in which "men-stealers" portrayed their sexual excursions among the enslaved young women as appropriate and even "just and indispensable." Bourne related, without using a name, the story of a Virginia planter who confessed to his wife that he "first carnally know at a very early age, every female slave on his plantation, as they successively advanced to maturity, and to that fact might be attributed their regard for him; so that they were very obedient and faithful, and he had not cause subsequently to exercise toward them any peculiar severity of treatment." In other words, the Virginia planter credited his sexual intimacy with these enslaved adolescent children for their loyal service to him and his family. As a result, the planter did not feel the need to apply severe treatment to coerce their obedience. The increase of his stock of slaves due to his sexual proliferation had a dual effect: it raised his net financial worth and social prestige while it forced his wife to live in a world and be served by mulatto slaves who all resembled her husband while she tried to ignore his infidelity. Once the plantation owner initiated such intimacy, they fiercely guarded the relations of their enslaved women and would "mercilessly scourge" the lovers of their enslaved adolescents in their presence. ${ }^{65}$

${ }^{65}$ Ibid, 59-60. 
On the flip side, young enslaved women were often bred specifically to be sold as virgin companions for their buyers. Bourne told of a story of a business man who delayed a transaction with an associate of Bourne's because he was attending a "girl-market" for "a sale of a number of likely nigger wenches this afternoon" between the ages of "fourteen to eighteen years of age." The buyer was excited because he planned "to buy one for my own use." ${ }^{66}$ The associate remarked that "they were all warranted virgins, and were sold expressly for concubinage and the manufacture of light colored slaves." At the "girl-market" the enslaved adolescents were demeaned and "were exposed, examined, [and] handled," in "open daylight" by "profligates half-drunk and constantly uttering the grossest obscenities which their lewd imaginations could invent[...]" The examinations by prospective buyers were excruciating as questions about "their personal purity, their age, their capacity for usefulness, and their various acquirements..." Bourne's friend saw the Georgia slave buyer the next day and he "was delighted with his female bargain" and had already "defiled his new purchase" the night before. ${ }^{67}$

Chattel slavery destroyed the familial bonds of African Americans on a daily basis for the sake of the domestic slave trade. Bourne therefore denounced the system of American slavery that legally condemned enslaved women to an unimaginable level of subjugation while it violated the moral precepts of God and erased family ties:

Slavery abolishes all the ties of consanguinity, for no relationship is admitted to exist between the white and the colored members of the same household. Under this ungodly evasion, the father will have carnal knowledge of a colored woman, and also with his own daughter by her; and the son will defile his own sister and

\footnotetext{
${ }^{66}$ Ibid.

${ }^{67}$ Ibid, 62-63.
} 
her mother; and thus all the distinctions of domestic life and commingled in one indiscriminate assemblage of unnatural monsters, who not only destroy the law of God and the instincts of humanity, but degrade woman to the lowest abyss of pollution and iniquity. ${ }^{68}$

Bourne believed that even women in the church could not expect to be protected because upon confiding to anyone in the church, "they would only unite to punish her." ${ }^{69}$ It would appear then that within American slavery sex trafficking, child sexual exploitation and incest were all legal and even protected in churches where the white offenders were not punished or excommunicated.

In a world when slave owners were sexual masters of the plantation universe and legally could and did as they wished with their female property, moral lines were not only blurred, they were completely erased and eventually were crossed by subsequent generations. Bourne, therefore, described lurid scenes of illicit sexuality between whites and blacks on Southern plantations. He believed that the sexually predatory behavior of plantation owners created an environment of "lewdness" and commonality of adolescent sexuality between white boys and black girls. In other cases, the permissiveness extended in sexual relations between the "colored women and her white nurselings." Even the white daughter of slave owners was influenced by an enslaved woman, who wanted revenge for her own violation at the hands of the white girl's father, to have sex with her son. In that way, Bourne believed that way "the sins of the fathers and mothers are visited upon their children." Bourne wondered aloud what would happen if black men, due to divine retribution, grew to wield the same sexual power over white women. $\mathrm{He}$

\footnotetext{
${ }^{68}$ Ibid, 64.

${ }^{69}$ Ibid, 70 .
} 
maintained that that, "If no other argument could be adduced in favor of immediate and universal emancipation, that single fact is sufficient." ${ }^{\prime 70}$

The sum of all villainies that took place on the plantation led Bourne to reject American slavery and urge white women in the north and south to advocate for its abolition. He believed the system to be both oppressive and corrupting. He observed how the system made white men and women eroded their work ethic thus infecting them with "incurable indolence." Slavery made the plantations "harem-like" insofar as it allowed white men to hold power over the bodies of as many enslaved women as his money could afford. White women who depended on the slave economy were forced to be complicit with the corruption, lacking the financial means to sustain themselves. Often they sought the comfort of a northern man, however, the man might himself, though initially shocked by the lurid plantation lifestyle and its "abominations" might soon grow accustomed to it and even become an apologist of the system. "It is therefore manifest," Bourne lamented, "that the customs of a slave plantation are destructive of personal purity and social order, and that the system can produce 'only evil continually."'71

Bourne therefore used the Bible to challenge white women in the south to take a stand against slavery leave southern plantations and to describe the institution in the most lurid terms. "The command of God is this: (2 Corinthians, vi. 14-18) 'Come out from among them, and be ye separate, and touch not the unclean!' Women who profess Christianity in the slave-holding States have a peculiar class of duties to perform." He urged them to hold no fellowship with preachers who were "kidnappers" and "man-

\footnotetext{
${ }^{70}$ Ibid, 73.

${ }^{71}$ Ibid, 73-74, 81-82, 85, 87-88, 99.
} 
stealers" or to remain in a church that was "sustained" by "slave-holding" lest they be considered being a part of an "ungodly confederacy" and be "rejected at the last day, as a consummate hypocrite, who in actual result aided to obliterate the command of God from its authority over the understandings and hears, and the consciences of men." Bourne had perhaps the strongest detestation possible for the American system of slavery equating it as, "only another name for rape, incest, polygamy and all unutterable uncleanness." Further, he described the system to "include every diabolical ingredient that is commingled in the "the golden cup full of abominations and filthiness of fornication," referencing Revelation 17:4. They were to even reject any donations or financial contributions because the money was said to be morally tainted. "A very large proportion of the wealth that is so prodigally squandered by the slave-holders," Bourne lamented, "is the direct result of that unrestricted licentiousness which is so universally practiced and encouraged. Yet much of that plunder has been cast into the treasury of the Lord." Bourne compared the revenue to that of brothels or robberies and considered them "an abomination unto the Lord thy God." Bourne attacked American slavery for the sexual lines that blurred within the system. He observed slave owners took liberties with their enslaved women while encroaching the marital relationships of the enslaved. ${ }^{72}$ He believed the link between American slavery and adultery would draw divine retribution and he applied scripture to make his point.

"When I had fed them to the full, then they committed adultery, and assembled themselves by troops in the harlots' houses. They were as fed horses in the morning. Every one neighed after his neighbor's wife. I have seen thine adulteries, and thy neighings, the lewdness of thy whoredom, and thine abominations on the hills in the fields. Shall I not visit for these things? saith the

\footnotetext{
${ }^{72}$ Ibid, 105-106, 111, 114, Deuteronomy 23:18.
} 
Lord. Shall not my soul be avenged on such a nation as this? Wo unto thee, $\mathrm{O}$ Jerusalem! wilt thou not be made clean?"73

It was on those moral grounds that Bourne called white women of the South to reject American slavery.

The Golden Rule was the cornerstone of Bourne's doctrine against American slavery. He urged white women to place themselves in the place of enslaved women that they might understand their plight. "Endeavor to place yourselves in the exact condition of the colored women" Bourne pleaded, "“who are drawn unto death, and ready to be slain.' Fancy yourselves every moment liable to be polluted — and, if you refuse submission, to be lacerated, and then forced by your tyrant to comply." Bourne, knowing his appeal would reach the ears of mothers, wives, lovers, daughters and sisters, urged compassion and a remembrance of the commandment against adultery. "Remember," he implored, "that as a mother, you would be exposed to separation, without a moment's warning, from your children, and as a lover, to be sent to an impassable distance from him who possessed all your affection. Recollect that the heart-rending anguish of that severance would be the punishment of a resistance to voluntary defilement combining all the most heinous transgressions of the seventh commandment." And he urged them to understand that the enslaved women had no recourse to defend themselves from there debased condition and forced to deal with such realities until death. "Add to all that melancholy picture the circumstance," Bourne beseeched, "that your compound wretchedness is thus certified without redress, and until the termination of your mortal

\footnotetext{
${ }^{73}$ Ibid, 120; Jeremiah 7:8-9.
} 
existence. ${ }^{.74}$ With such an appeal Bourne hoped to arouse the compassion of white women and encourage them to hate and fight against American slavery.

The writings of Bourne and the Grimké sisters had a considerable effect on northern women. And Garrison was pleased in 1837 when he surveyed the amount of work that female antislavery societies had done on behalf of abolition. And if 1837 made him happy, he had to be overjoyed by the time 1838 came around. An organized petition campaign spearheaded which the female societies participated was launched in May 1837. By December 1838 the campaign netted 414,000 signatures against the annexation of Texas as a slave state and the abolition of slavery in the District of Columbia. Of those signatures, 201,130 were the signatures of women. Garrison was giddy about the participation level of women in the movement and he compared them to the efforts of women in the British antislavery movement. "As in England, so in this country," Garrison said, "the women have done and are doing more for the extirpation of slavery than the other sex. In their petitions to Congress, they outnumber us at least three, perhaps five to one." 75 That the women signatures only amounted to just less than half the total of signatures might cast doubt on Garrison's estimation that the women petitions were "five to one." He might have been exaggerating. Notwithstanding his overstatement, he was pleased that women were engaged in a real way in the crusade against American slavery. He could thank George Bourne, Maria Stewart and the Grimké sisters for their

\footnotetext{
${ }^{74}$ Ibid, 126.

${ }^{75}$ William Lloyd Garrison to Elizabeth Pease, 6 November 1837, in Louis Ruchames, ed., The Letters of William Lloyd Garrison, vol. 2: A House Dividing Against Itself, 1836-1840 (Cambridge: Harvard University Press, 1971), 326 quoted Lois A. Brown in "William Lloyd Garrison and Emancipatory Feminism in Nineteenth-Century America," 43.
} 
biblical first-hand testimony against American slavery that by its sheer moral force of exposition provoked northern females to rise and fight for their sisters in bondage, even if southerners largely ignored their entreaties against American slavery. 


\section{CONCLUSION}

\section{The Civil War as Divine Retribution for American Slavery}

When Abraham Lincoln delivered his second inaugural address on March 4, 1865 , he finally did what every abolitionist since the $18^{\text {th }}$ century hoped would be done: he took national responsibility before God for the national sin of American slavery. But alas, it was too little too late. The divine retribution abolitionists warned of was not averted. The sum of all villainies had totaled into massive destruction on multiple levels. Sure, he had done all he could to abolish slavery. Lincoln issued the Emancipation Proclamation that freed the slaves in the rebellious states in 1863, and recently worked with Congress to pass the $13^{\text {th }}$ Amendment abolishing slavery throughout the nation. His reforms, however, were only done as the nation was embroiled in internecine war that by the time of his address had caused over 850,000 casualties. ${ }^{1}$ The Emancipation Proclamation only took effect after ten battles, the fiercest of which, Antietam, had demanded over 22,000 lives in a single day. ${ }^{2}$ It was exactly what the abolitionists had implored the nation to avoid. The abolitionists had predicted destruction would come because of American slavery, some even prophesied the internal and divisive nature of the conflict that would result from the institution. Abolitionists made their arguments using the Bible as their guide and Lincoln would respond in kind in his second inaugural address.

\footnotetext{
${ }^{1}$ Charles R. Cooper, Chronological And Alphabetical Record of the Engagements of the Great Civil War With the Casualties On Both Sides And Full And Exhaustive Statistics And Tables of the Army And Navy, Military Prisons, National Cemeteries, Etc., Etc., Milwaukee, Wis.: The Caxton press, 1904, 313-314, Hathi Trust Digital Library, (accessed September 30, 2017).

${ }^{2}$ Ibid.
} 
From 1837 to 1865 abolitionists from both sides of the Atlantic continued their biblical arguments against American slavery and warned the nation of the coming wrath over the institution. William Lloyd Garrison, George Bourne, The Grimke Sisters, Theodore Weld, Sojourner Truth, George Thompson, Frederick Douglass, Harriet Beecher Stowe, John Brown, and George B. Cheever all leveled some sort of biblical rationale for the immediate abolition of slavery to avert divine retribution and national disaster. ${ }^{3}$ These, of course, do not include those who made the same argument prior to 1837 and as far back as the time of the Quakers in the mid- $18^{\text {th }}$ century. The $19^{\text {th }}$ century arguments were not leveled in an obscure manner but were broadcast to the nation in the form of pamphlets, tracts, books, proclamations, publications, etc. Abolitionists argued within the context of every national development and made the connection to overall

\footnotetext{
${ }^{3}$ William Lloyd Garrison, "Anti-Slavery Celebration of the Fourth of July, 1856," William Lloyd Garrison, President, National Anti-Slavery Standard (New York, New York, United States), Saturday, July 12, 1856; Issue 8, Slavery and Anti-Slavery, Gale, Florida International University (accessed October 1, 2017); George. A Bourne, condensed anti-slavery Bible argument, New York, 1845, 17, 19, Slavery and AntiSlavery, Gale, Florida International University, (accessed October 1, 2017); Anti-Slavery Convention of American Women (1st: 1837: New York, N.Y.), An appeal to the women of the nominally free states: issued by an Anti-Slavery Convention of American Women: held by adjournments from the 9th to the 12th of May, 1837, 2nd ed. Boston, 1838, 10, Slavery and Anti-Slavery, Gale, Florida International University, (accessed October 1,. 2017); Theodore Dwight Weld, The Bible against slavery: an inquiry into the patriarchal and Mosaic systems on the subject of human rights, New York, 1837, Slavery and AntiSlavery, Gale, Florida International University, (accessed October 1, 2017); Olive Gilbert, Narrative of Sojourner Truth : a northern slave, emancipated from bodily servitude by the State of New York, in 1828 : with a portrait, Boston, 1850, ix-x, Slavery and Anti-Slavery, Gale, Florida International University, (accessed October 1, 2017); George Thompson, American slavery : a lecture delivered in the Music Hall, Store Street, Monday, Dec. 13th, 1852 by George Thompson, London, 1853, 6, Slavery and AntiSlavery, Gale, Florida International University, (accessed October 1, 2017); Frederick Douglass, Narrative of the life of Frederick Douglass : an American slave, Boston, 1846, 121-123, Slavery and Anti-Slavery, Gale, Florida International University, (accessed October 1, 2017); Harriet Beecher Stowe, The key to Uncle Tom's cabin : presenting the original facts and documents upon which the story is founded: together with corroborative statements verifying the truth of the work, Boston, 1854, 104, 191, 206, 488, Slavery and Anti-Slavery, Gale, Florida International University (accessed October 1, 2017); Richard Davis Webb, The life and letters of Captain John Brown, who was executed at Charlestown, Virginia, Dec. 2, 1859, for an armed attack upon American slavery: with notices of some of his confederates edited by Richard D. Webb, London, 1861, 447, Slavery and Anti-Slavery, Gale, Florida International University, (accessed October 1, 2017); George Barrell Cheever, The fire and hammer of God's word against the sin of slavery : speech of George B. Cheever, D.D., at the anniversary of the American Abolition Society, May, 1858, NewYork, 1858, Slavery and Anti-Slavery, Gale, Florida International University, (accessed October 1, 2017).
} 
oppression characterized within American slavery. Whether it was the removal of Native Americans from their lands, to the war with Mexico, to the Compromise of 1850, the Dred Scott decision and John Brown's execution, Abolitionists continued their sustained critique of the nation's tolerance of American slavery. They went from house to house and spoke in public places to anyone who would hear their plea on behalf of the enslaved Africans. By the time Lincoln addressed the nation in 1865, there was a wealth of biblical antislavery literature from which to draw inspiration to frame the cataclysm of the Civil War in biblical and providential terms. Only, by the time of Lincoln's second inaugural address, pastors, chaplains and congressmen throughout the North were chiming in with their own biblical critiques and interpretations of the catastrophe they were witnessing in their nation.

Even before the war began, there was a dread throughout the nation as Lincoln was elected to office. Immediately after his election, South Carolina declared on November 9, 1860 that Lincoln's election was a "hostile act" and announced plans to convene delegates from throughout the state to consider secession from the Union. Within a month, on December 17, South Carolina state delegates voted unanimously to secede from the Union and announced their decision. Understanding that the nation was tearing apart, President James Buchanan, meanwhile, appealed to the nation on December 14, 1860 that they should pray. Despairing that "Hope seems to have deserted the minds of men," Buchanan believed that "God's arm alone can save us from the awful effects of our own crimes and follies." ${ }^{4}$ It would seem, therefore, that Buchanan somehow sensed

\footnotetext{
${ }^{4}$ James Buchanan quoted by T. H. (Thomas Hewlings) Stockton, Address by Thomas H. Stockton, Chaplain U.S.H.R.: delivered in the hall of the House of Representatives, on the day of National
} 
that the present crisis that the nation faced was due to the nation's "crimes and follies."

As the Continental Congress had done in 1776, Buchannan was now, as outgoing

President, calling for a day of "fasting, humiliation and prayer" to take place on January

4, 1861. Pastors responded to the call to pray and fast by delivering sermons that

interpreted the times.

As southern states began to follow South Carolina's lead into secession, pastors in the North began to voice their overwhelming sense of guilt over the crime of American slavery. They spoke to their congregations and openly asked why the nation was "clothed with mourning" and their hearts filled "with anxiety and the most dreadful apprehensions?"5 They averred that it was "God's judgments" that were at hand to "teach righteousness." ${ }^{\prime 6}$ Others expressed an overwhelming sense of guilt and proclaimed that "we are verily guilty concerning our brother" meaning enslaved African Americans. ${ }^{7}$ They invoked images of the spilt blood of African Americans that "cried out to God"

Humiliation, Fasting, and Prayer, Friday, January 4, 1861, Washington, [D.D], 1861, 4, Slavery and AntiSlavery, Gale, Florida International University, (accessed September 28, 2017).

${ }^{5}$ John H. Chew, God's judgments teaching righteousness: a sermon delivered on the national fast day, January 4, 1861, in St. Matthew's parish, Prince George's County, Md. Washington, 1861, 3, 6, 10, Slavery and Anti-Slavery, Gale, Florida International University (accessed September 28, 2017).

${ }^{6}$ Ibid.

${ }^{7}$ Rev. Sir Henry Moncrieff, "Speech of Rev. Sir Henry Moncrieff," National Anti-Slavery Standard (New York, New York, United States), Saturday, March 23, 1861; Issue 45, Slavery and Anti-Slavery, Gale, Florida International University (accessed September 28, 2017); "The War-Its Cause and Cure," The Liberator (Boston, Massachusetts), Friday, May 03, 1861, 70; Issue 18, Slavery and Anti-Slavery, Gale, Florida International University (accessed September 28, 2017); Samuel J. May, "A Sermon on Our Civil War," The Liberator (Boston, Massachusetts), Friday, May 24, 1861, 84; Issue 21, Slavery and AntiSlavery, Gale, Florida International University (accessed September 28, 2017); "The National Disaster," The Principia (New York, New York, United States), Saturday, July 27, 1861, 709; Issue 37, Slavery and Anti-Slavery, Gale, Florida International University, (accessed September 28, 2017). 
from the ground in accusation against their oppressors. ${ }^{8}$ The biblical names they repeated were those of the brothers Cain and Abel. As the story goes in Genesis 4, Cain murdered his brother Abel and Cain spilled his blood. When God confronted Cain for his actions, he said to Cain that Abel's blood "cries out to me from the ground." Another refrain preachers used was that of the woman Rachel who unconsolably wept for her children (Jeremiah 31:15, Matthew 2:18). White pastors felt an overwhelming sense that the cry of this spilt blood due to American slavery had reached the ears of God and that divine retribution was at hand. ${ }^{9}$ They invoked the prophets Ezekiel and Jeremiah who cried that "the iniquity Land is full of blood and the city is full of injustice" and that the Lord was now asking, "Shall I not visit for these things?" and "Shall not my soul be avenged on such a nation as this?" 10 Pastors understood that the nation was descending into internecine war and they interpreted this to be nothing other than the hand of God. Pastors warned their adherents that they must prepare themselves because for "God's vengeance" and his "judgment upon the whole nation." 11 They entreated their congregants to pray, fast and confess the sins of the nation. Yet, even as they urged their

\footnotetext{
${ }^{8}$ J.B. (Joseph Baugher) Bittinger, A sermon preached before the Presbyterian churches of Cleveland: on the national fast day, September 26, 1861, Cleveland, 1861, 19-20, Slavery and Anti-Slavery, Gale, Florida International University (accessed September 29, 2017).

${ }^{9}$ Samuel May, The fugitive slave law and its victims, Rev and enlarged ed., New York, 1861, 5, 162, Slavery and Anti-Slavery, Gale, Florida International University, (accessed September 29, 2017).

${ }^{10}$ George Duffield, The God of our fathers: an historical sermon preached in the Coates' Street Presbyterian Church, Philadelphia, on Fast Day, January 4, 1861, Philadelphia (Philadelphia), 1861, 8, 20, 22, Sabin Americana, Gale, Cengage Learning (accessed September 28, 2017); Scripture references are Ezekiel 9:9 and Jeremiah 5:9; See also Slavery in rebellion: an outlaw: how to deal with it, American Reform Tract and Book Society (Series): Occasional; no. 5. [Cincinnati, Ohio], [1861?], 1, Slavery and Anti-Slavery, Gale, Florida International University, (accessed Sept. 28, 2017).

${ }^{11}$ Slavery in rebellion: 1-2; Catechism for free working men / by the son of a blacksmith. [S.1.], [n.d.] Slavery and Anti-Slavery, 7, Gale, Florida International University, (accessed September 29, 2017).
} 
members to pray, they pointed to the sin that should be confessed and decried. It was the sin of slavery and its concomitant oppression. God had finally heard the cries and the groans of the oppressed just as he had the cries of the Israelites in Egypt. ${ }^{12}$ The "bitterest" cries of the oppressed had become irresistible to God and "very piercing" into his ears. ${ }^{13}$ Though unseen by human eyes, the blood of the oppressed was everywhere and had "polluted the land." 14 That innocent blood shed by the oppressor drenched the land in plain sight of the Almighty and he was ready to act on their behalf. Pastors bemoaned this load of guilt and hoped desperately before their congregations that the "God in infinite mercy grant, that we may, this day, so heartily repent of our sins, that the atoning [sic] generation may not be our own." 15

One year into the war, as the death count of young American men was mounting and their home communities were collectively mourning, ministers and chaplains tried to make sense of the carnage. It was as they suspected: a visitation from God. The numbers of the dead were staggering and unlike anything the American people had seen. ${ }^{16}$ The almost 26,000 Mexican-American war casualties never approached the same numbers as

\footnotetext{
12 The North and the South misrepresented and misjudged, or, A candid view of our present difficulties and danger and their causes and remedy, Philadelphia, 1861, 18-19, Sabin Americana, Gale, Cengage Learning, (accessed September 28, 2017).

13 Ibid.

14 Ibid.

${ }^{15}$ Duffield, God of our Fathers, 20; see also Oakey, P. D.. The war, its origin, purpose, and our duty respecting it: a sermon preached in the First Presbyterian Church, Jamaica, L.I., on the day of ... NewYork, 1861, 20, Sabin Americana. Gale, Cengage Learning, (September 29, 2017).

${ }^{16}$ Charles R. Cooper, Chronological And Alphabetical Record of the Engagements of the Great Civil War With the Casualties On Both Sides And Full And Exhaustive Statistics And Tables of the Army And Navy, Military Prisons, National Cemeteries, Etc., Etc., Milwaukee, Wis.: The Caxton press, 1904, 313-314, Hathi Trust Digital Library, (accessed September 30, 2017)
} 
what Americans were witnessing in the first year and a half. Well over 100,000 soldiers were cut down between the beginning of the war and the end of $1863 .{ }^{17}$ In funerals ministers sought to console family members by offering a rationale for the death of their sons, brothers, husbands and fathers. Blood was a recurring theme of the comforting and emotive discourse as ministers sought to square the blood of soldiers with the "crying blood" of the oppressed. Though at the beginning of the war, there was talk of the national sin of American slavery, no one anticipated the extent of the carnage the war would bring about. Pastors warned their congregants that "We must fight against our brethren; [and] blood must flow, and there must be wailing all over the land." 18

Abolitionists like William Lloyd Garrison readily reminded Americans that they had warned the nation that such a time might come. At a speaking engagement in 1862 Garrison reminded his hearers that abolitionists had for 30 years publicly warned the nation. He asked, "Would there now be any civil war to talk about?"19 Garrison bemoaned that the nation had failed to heed abolitionist warnings. Instead the nation had "been hunted as outlaws, or denounced as wild fanatics; while the slaveholders have been encouraged to go on making one demand after another." ${ }^{20}$ Garrison therefore said that the

\footnotetext{
${ }^{17}$ Ibid, 335 .

${ }^{18}$ William A. Stearns (William Augustus), Necessities of the war and the conditions of success in it: a sermon preached in the village church, before the college and the united congregations of the town of Amherst, Mass., on the national fast day, Thursday, September 26, 1861. 2nd ed., for the college, Amherst, Mass., 1861, 15, Slavery and Anti-Slavery, Gale, Florida International University (September 29, 2017);

Henry D. Moore, Our country--its sin and its duty: A discourse: on the occasion of the national fast, September 26th, 1861, Portland [ME], 1861, 8, Slavery and Anti-Slavery, Gale, Florida International University, (accessed September 29, 2017).

${ }^{19}$ William Lloyd Garrison, Three unlike speeches, New York, 1862, 40, Slavery and Anti-Slavery, Gale, Florida International University, (accessed September 29, 2017).

${ }^{20}$ Ibid, 41.
} 
results spoke for themselves. "Therefore it is that the vials of Divine Retribution," Garrison cried, "are poured out so impartially. We are suffering; our blood flowing, our property is melting away — and who can see the end of it?" ${ }^{21}$ While Garrison saw no end in sight God's visitation on the land, he was convinced about the source of the controversy. "Our crime against these four millions of slaves," Garrison lamented, "and against a similar number who have been buried can not be adequately described by human language." 22 Garrison confessed for the whole nation. "Our hands are full of blood," Garrison cried, "and we have run to do evil; and now a heavy but righteous judgment is upon us!"23 Female abolitionists in Philadelphia, like Garrison, bemoaned that their warnings had not been heeded. They too, had warned the nation for thirty years against the oppression of "the widow and the fatherless, the stranger and the poor." ${ }^{24}$ Yet, the abolitionist society of Philadelphia believed that the there was more suffering to come that depended on the nation's willingness to repent. If the nation refused, they the nation should expect that in "the dim future stands the angel of sterner retribution, waiting the nation's response to God's judgment call."25

Congressmen found themselves reaching for biblical explanations for the catastrophe of war. "This is" opined the Indiana Congressman George W. Julian of

\footnotetext{
${ }^{21}$ Ibid.

${ }^{22}$ Ibid.

${ }^{23}$ Ibid.

${ }^{24}$ Philadelphia Female Anti-slavery Society, Twenty-eighth annual report of the Philadelphia Female Antislavery Society, Philadelphia, 1862, 16, Slavery and Anti-Slavery, Gale, Florida International University, (accessed September 29, 2017).

${ }^{25}$ Ibid.
} 
Indiana, "one of the grand judgment days of history." ${ }^{26}$ As far as he understood, "the voice of Jehovah, calling the nation to account for its sins, and teaching, through the terrible lesson of civil war, that the unjust thing shall not prosper." ${ }^{27}$ He called the war a "national retribution." 28 Other pastors believed that only the convulsion of war could dislodge "so huge a wrong" that was so deeply rooted in American culture. They posited that "If God is just, so huge a wrong can never die a natural death." ${ }^{29}$ Because it had stood so long in American life, it had to be dealt with by God himself. Americans had "a long-standing debt of retribution [that] must be audited and canceled."30

Pastors were moved by the thousands of grieving families that mourned their fallen husbands, fathers, sons, and brothers and sought to console them. They pointed them to the grand scale of God's purposes and reasoned that for the nation to make a "new covenant of freedom, righteousness and God" the nation must be baptized in blood. ${ }^{31}$ They called the fallen soldiers "martyrs" who were "shedding the blood of a new covenant" and were "striking off the chains from millions of human beings." 32 They

\footnotetext{
${ }^{26}$ George Washington Julian, The cause and cure of our national troubles: speech of Hon. Geo. W. Julian, of Indiana, delivered in the House of representatives, Tuesday, ... Washington, D.C., 1862, 2, Sabin Americana, Gale, Cengage Learning, (accessed September 29, 2017).

${ }^{27}$ Ibid.

${ }^{28}$ Ibid.

${ }^{29}$ Frederick Gorham Clark, Gold in the fire, our national position: a sermon, preached ... on Thanksgiving Day, Nov. 27th, 1862, New-York, 1862, 14, Sabin Americana, Gale, Cengage Learning, (accessed September 29, 2017).

${ }^{30}$ Ibid.

${ }^{31}$ Ibid.

${ }^{32}$ William Henry Furness, $A$ word of consolation for the kindred of those who have fallen in battle: a discourse delivered September 28 1862, Philadelphia, 1862, 7, Sabin Americana, Gale, Cengage Learning, (accessed September 29, 2017).
} 
sought to explain the reason for the enormous bloodshed in the nation. Slavery was such a deep sin that it required a price to be paid. As Christ had shed his blood on the cross for the "remission" or forgiveness of sins, so soldiers most shed their blood as "martyrs and heroes" for the "new covenant" the nation was "making with Righteousness, and with Liberty, and with God." "33 They sought to make sense of the "the terrible conflict that is desolating and drenching the land" and declared that "It has been a year of blood." 34 They spoke of "ensanguined battle fields" and of "carnage and death," the ground "drank in the life-blood of thousands upon thousands of the noblest of America's Sons." 35 This was necessary to wipe away "so heinous" a sin as slavery, that only "blood could wipe it out." ${ }^{36}$ This was, as the pastors saw it, "the philosophy of the Atonement." 37 Pastors invoked the example of Egypt; how Pharaoh refused to let the slaves go free until "the angel of death had visited every household and sealed the reluctant decree of deliverance with the life-blood of her first born." 38 Pastors consoled by gently asking,

If history makes it fearfully manifest that great national crimes must be atoned for with human blood, what must we not expect as punishment and as price of deliverance from a crime so aggravated and immeasurable as Americans slavery ${ }^{39}$

\footnotetext{
${ }^{33}$ Ibid, 22-23.

${ }^{34}$ Frederick A. Noble, Blood the price of redemption: a Thanksgiving discourse delivered in the House of Hope, Nov. 27, 1862, 3, St. Paul, 1862, 3, Slavery and Anti-Slavery, Gale, Florida International University (accessed September 29, 2017); Ezra Mundy Hunt, The war and its lessons, New York, 1862, 26, Sabin Americana, Gale, Cengage Learning, (accessed September 29, 2017.

${ }^{35}$ Noble, Blood the price of redemption, 4.

${ }^{36} \mathrm{Ibid}, 6$.

${ }^{37}$ Ibid.

${ }^{38} \mathrm{Ibid}, 8$.

${ }^{39}$ Ibid, 19.
} 
Lincoln decided to formally interject the issue of slavery into the conflict in 1862 and issued the Emancipation Proclamation that freed the slaves in states that were in rebellion. The measure would take effect on January 1, 1863. The executive order also allowed African Americans to join the Union armed forces. Though it is not mentioned in the executive order, what the order did in effect was vacated the Fugitive Slave Law of 1850, by declaring that slaves escaping from the states in rebellion would not be turned over to their masters in the South. The measure, in effect, provided a sigh of relief not only to enslaved African Americans, it also officially interjected moral authority to the North. Lincoln's action gave at least one pastor to the room to exhort his congregants to believe further in the war's righteous cause and their loved ones had died within the will of God. "The President has spoken," cried Rev. Frederic A. Noble of Minnesota, "The issue is defined. A proclamation has been uttered, that not only immortalizes its author, but puts our nation in line of God's requirement." ${ }^{40}$

While Lincoln's Proclamation freed thousands of slaves, it did not mitigate the blood flow and the nation's suffering. Among the most bloody battles that took place in the summer of 1863 in Gettysburg, Pennsylvania, where there were over 50,000 casualties in a series of skirmishes between July 1-3. At the dedication of the battleground at Gettysburg on November 19, 1863, Lincoln sought to make sense of all the bloodshed for the American public and put the war itself in a biblical context. While Lincoln and others were there to, "dedicate a portion of that field," in Gettysburg for men "who here gave their lives that that nation might live." ${ }^{41}$ In this sense, Lincoln positioned

\footnotetext{
${ }^{40}$ Noble, Blood the price of redemption, 20.
} 
the soldiers as martyrs and Christ-like figures who were giving their lives "full measure of devotion" so that others "might live." 42 This gave their lives and deaths a redemptive quality as pastors throughout the north had been affirming to their grieving families. Lincoln also used the occasion to exhort his national adherents that the war was for them the opportunity to be inspired and to gain "from these honored dead we take increased devotion to that cause for which they gave the last full measure of devotion. ${ }^{43}$ Lincoln urged the national congregants just as a sinner repents and is baptized for the forgiveness of sins and a rebirth, so "this nation, under God, shall have a new birth of freedom—and that government of the people, by the people, for the people, shall not perish from the earth. ${ }^{.44}$ Lincoln was now not just Commander-In-Chief, he was now Pastor-In-Chief, comforting and exhorting a grieving nation. The Inaugural Thanksgiving provided Lincoln another opportunity to minister to the grieving nation. In October, Lincoln issued a proclamation to appoint the last November of every year "as a day of Thanksgiving and Praise to our beneficent Father who dwelleth in the Heavens." ${ }^{45}$ Ever mindful of the sins that caused the war and grieving families of those who had died in the Civil War thus far, Lincoln urged that prayers be offered up "with humble penitence for our national perverseness and disobedience, commend to his tender care all those who have become

\footnotetext{
${ }^{41}$ Abraham Lincoln, and Roy P. Basler, Abraham Lincoln: His Speeches and Writings (Millwood, New York: Kraus Reprint Co, 1976), 734.

${ }^{42}$ Ibid.

${ }^{43}$ Ibid.

${ }^{44}$ Ibid.

${ }^{45}$ Lincoln and Basler, Lincoln: His Speeches and Writings, 726-729.
} 
widows, orphans, mourners or sufferers in the lamentable civil strife in which we are unavoidably engaged..." ${ }^{46}$

Lincoln's consoling words were not enough to stem the tide of grief. Blood continued to flow and reports from the front lines continued to pour in. Questions searching for the meaning for so much bloodshed persisted. By 1864 there was now a new consideration. Besides hemorrhaging blood, the United States was now losing money on a war that seemed to go on interminably. Lincoln and the Union poured $\$ 67$ million into the Civil War from the beginning of the year to June 30, 1861. Within the next year, the federal government expended another $\$ 469$ million. By 1864 the U.S. was well on its way to spending more than $\$ 1.4$ trillion to keep the Union together. ${ }^{47}$ The nation's treasury was just about tapped out and even had to borrow money by offering bonds to its richest citizens. The American people now added "treasure" to their lament of "losing blood" for the cause of freedom. Whereas between 1861 and 1863 the nation lamented the blood that had been shed for freedom, as early as 1863 and now in 1864 they mourned the loss of "blood and treasure," now a recurring theme in the speeches concerning the war. ${ }^{48}$

\footnotetext{
${ }^{46}$ Ibid.

${ }^{47}$ Sven Beckert, The Monied Metropolis: New York City and the Consolidation of the American Bourgeoisie, 1850-1896 (Cambridge, UK: Cambridge University Press, 2001), 117.

${ }^{48}$ W. E. Adams, The slaveholders' war: an argument for the North and the Negro, Manchester, 1863, Slavery and Anti-Slavery, Gale, Florida International University (accessed September 30, 2017); Charles Eliphalet Lord, Slavery, secession and the Constitution: An appeal to our country's loyalty, Boston, 1864, 49, 52, Slavery and Anti-Slavery, Gale, Florida International University, (accessed September 30, 2017); Chaplain of the U. S. Army, The nation's sin and punishment, or, The hand of God visible in the overthrow of slavery, New York, 1864, 16, Slavery and Anti-Slavery, Gale, Florida International University, (accessed September 30, 2017); Charles P. Kirkland, (Charles Pinckney), The destiny of our country, New York, 1864, 63, Slavery and Anti-Slavery, Gale, Florida International University (accessed September 30, 2017); Robert Dale Owen, The wrong of slavery, the right of
} 
Abolitionists, meanwhile, continued to keep the pressure on Congress and the President, to abolish slavery and they based their message on biblical arguments. One who emerged with the opportunity to directly challenge Congress was George B. Cheever. Although trained as a minister, Cheever was a standard bearer of Christian orthodoxy and a critic of American slavery. Born and raised in Hallowell, Maine by an encouraging mother after having lost his father at the age of 12 . Cheever made a name for himself as a human rights advocate by challenging President Andrew Jackson's Indian Removal policy. He wrote and published a piece for the American Monthly Magazine in 1830 titled, "Removal of the Indians" in which he excoriated the nation's forced migration of the Southeast Indians. ${ }^{49}$ By the 1850 s Cheever's was crusading against slavery and earning a national reputation as an abolitionist. His targets were the Compromise of 1850, the Fugitive Slave Act, and the Kansas-Nebraska crisis and he was joined by abolitionists throughout the land. Cheever joined in the attack by publishing pamphlets and having his sermons reprinted for his religious audiences. He enjoined slavery in his unique and dynamic way when in 1857 he wrote and published God Against Slavery: And the Freedom and Duty of the Pulpit to Rebuke it, As a Sin Against God. His preaching against slavery took on a more biblical tone when in 1858 Cheever published The Fire and hammer of God's Word Against the Sin of Slavery. In his The Guilt of Slavery and the Crime of Slaveholding, Demonstrated from the Hebrew and Greek Scriptures Cheever relied on the Hebrew Old Testament, the scriptures used by the emancipation, and the future of the African race in the United States, Philadelphia, 1864, 21, Slavery and Anti-Slavery, Gale, Florida International University, (accessed September 30, 2017).

${ }^{49}$ Nicholas Guyatt, Providence and the Invention of the United States, 1607-1876 (New York: Cambridge University Press, 2007), 280. 
Hebrew Prophets against slavery while defining it was a sin against God. ${ }^{50}$ This theological progression thus prepared him to interpret the Civil War in biblical Old Testament terms and in public terms.

On September 30, 1861, the war had only been five months old. The Confederate States of America (CSA) had won the first major battle in the war at the First Battle of Bull Run and early optimism gave way to trepidation. Many in northern and southern states alike called for days of fasting to seek providential help in the war. One such occasion provided Cheever with the chance to interpret the meaning of the war in a sermon chronicled in the New York Times. On this day Cheever expounded on his doctrine that the war was a punishment from God for the "sin" of slavery. ${ }^{51}$ Deducing that the war was caused by slavery, Cheever rejected American belief that the country could be saved with slavery intact. He expounded on the scripture in Isaiah 58:6. "Is not this the fast that I have chosen? To loose the bands of wickedness, to undo the heavy burdens, and to let the oppressed go free, and that ye break every yoke?"52 Cheever maintained that the "sin" of the U.S. was its refusal to "let the oppressed go free" or to "loose every yoke." He argued that "God speaks on the occasion of this National Fast, as never before in all history, and speaks through the consequences and to the consciousness of our great national crime and guilt, and calls us to repentance." ${ }^{53}$ Cheever pointed to

\footnotetext{
${ }^{50}$ Guyatt, Providence, 280.

${ }^{51}$ George B. Cheever, Discourse by Rev. Dr. Cheever, September 27, 1861, New York Times (1857-1922) Retrieved from http://ezproxy.fiu.edu/login?url=https://search-proquestcom.ezproxy.fiu.edu/docview/91593652? accountid=10901 (accessed September 30, 2017).

${ }^{52}$ Ibid.

${ }^{53}$ Ibid.
} 
the nation's war as the consequences of that sin. He quoted Ezekiel 14:13 and 21 to argue that when a nation sins against God, God would "stretch out mine hand upon it." War, said Cheever, was a form of punishment that God meted out on a guilty nation. ${ }^{54}$

Cheever's public proclamation published in the New York Times thrust him into the public spot light and earned him a public audience with the House of Representatives. Appearing before the highest legislative authority in the land, Cheever proved to be every bit the powerful and radical prophet on behalf of the poor and against American slavery that the body would host. Cheever opened his address with a direct quote from one of the Hebrew Prophets, Ezekiel:

The people of the land have used oppression and exercised robbery, and have vexed the poor and needy; yea, they have oppressed the stranger wrongfully. I sought for a man among them that make up the hedge and stand before me for, that I should not destroy it; but I found none. Therefore have I poured out mine indignation upon them; I have consumed them with the fire of my wrath; their own ways have I recompensed upon their heads saith the Lord God. ${ }^{55}$

It is clear by the tone of the scripture Cheever, employed pointed language to summon and indict the nation's highest legislative leadership. As Ezekiel accused the Israelites of "oppression" and "robbery" against the "poor and needy," Cheever also accused the Congress of oppression against African Americans. They had a "controversy against

\footnotetext{
${ }^{54}$ The modern version of this scripture reads: "For this is what the Sovereign Lord says: how much worse will it be when I send against Jerusalem my four dreadful judgments - sword and famine and wild beasts and plague - to kill its men and their animals!" (The Holy Bible, New International Version. Zondervan, 1984).

${ }^{55}$ Ezekiel 22:29-31 cited in George B. Cheever, Rights of the Coloured Race to Citizenship and Representation: And the Guilt and Consequences of Legislation against Them, a Discourse Delivered in the Hall of Representatives of the United States, in Washington, D.C., May 29, 1864, New York: Francis \& Loutrel, 1864, 1, http://find.galegroup.com/openurl/openurl?url_ver=Z39.882004\&url_ctx_fmt=info:ofi/fmt:kev:mtx:ctx\&res_id=info:sid/gale:NCCO\&ctx_enc=info:ofi:enc:UTF8\&rft_val_fmt $=$ info:ofi/fmt:kev:mtx:unknown\&rft.artnum=CSEGLH154227024\&req_dat=info:sid/gale:ug nid, (accessed October 1, 2017).
} 
God" over a "perversion of our own Constitution and Government for the oppression of millions: the impiety, injustice, and inhumanity of our legislation against the coloured race, on account of their colour..."

The text of the speech itself has the subtitle "Counts of the Indictment." ${ }^{57}$ Cheever set forth the counts of his indictment against a nation that had yet to abolish slavery through an amendment to the Constitution. Oppression was directed toward the "stranger" who in this case was a people of color. This was in spite of "divine law" which held the stranger was considered "a sacred class, guarded by [its] special provisions." The U.S. had "disregarded and violated the peculiar injunctions and claims of God and humanity in behalf of that class." All this was done in "wanton defiance, not only of the spirit of their own Constitution, and the law of natural equity, but against the letter of their won covenant and laws of liberty and justice." Cheever held that the U.S. had "thus belied the nature of the institutions, both of freedom and Christianity." 58

Continuing his indictment, Cheever listed the specific reasons for which he believed God had a "controversy" with the nation. Cheever said the U.S. "used oppression" as part and parcel of "their policy;" and "used it as an instrument of power, and made it the means of their prosperity." ${ }^{, 59}$ Cheever attacked what U.S. Congress for using oppression as a part of its policy. Cheever needed only to review American law from the inception of the Constitution in 1789. That this policy lasted until 1864 made

\footnotetext{
${ }^{56}$ Ibid.

${ }^{57}$ Ibid, 4 .

${ }^{58}$ Ibid.

${ }^{59}$ Ibid.
} 
clear to him the direct reason the nation was under God's chastisement. "Even now," said Cheever, "in the very centre of this rebellion and conflict we have renewed our original sin, the very sin on account of which God is striking us. We have put the iniquity into direct legislation. We have dared to make the colour of skin the ground on which we adjudge a whole race of millions of our fellow beings to slavery." ${ }^{\prime 60}$ Despite the Emancipation Proclamation, slavery had not been abolished and the Fugitive Slave Law had not been annulled and the racial overtones of the Dred Scott decision had not been vacated. Supreme Court Justice Taney asserted, "The black man has no rights which the white man is bound to respect." Furthermore, there were no prospects that African Americans would one day be granted citizenship or suffrage.

Second, Cheever accused Congress of using oppression as an instrument of power. Although the Emancipation Proclamation served to free thousands of slaves in the Confederacy, Cheever charged it was done as a measure of war. Since only those slaves in states "in rebellion" were declared free, thus leaving untouched those in the Border States, Cheever could summon no other conclusion that such "justice" was employed as "an instrument of power" in warfare. "What shall be said," Cheever demanded, "of a government, church, and people, maintaining, under all circumstances, the right of oppression by law if it is judged expedient, but disavowing all right of protection and beneficence, all right of doing justice, except in a state of war?" ${ }^{61}$ Many, including Lincoln, understood the power available in deploying Negroes to fight for the North. By the end of the war, the Union added to their military power around 180,000 African

\footnotetext{
${ }^{60} \mathrm{Ibid}, 5$.

${ }^{61}$ Ibid, 6.
} 
American soldiers. ${ }^{62}$ Cheever, therefore, gave the Union little credit for its Emancipation Proclamation, calling it an "instrument of power." 63

Prosperity, argued Cheever, was a by-product of the nation's oppression. From the nation's inception, up to the Civil War, cotton guided its economic rise to the levels of European states. African Americans played a key role in this economic development as they planted, grew and cultivated the cotton. Both the U.S. and Great Britain benefitted as cotton gave impulse to American land expansion in the South and the industrial revolution in Great Britain. Industry encouraged tremendous demand that was met by a cotton supply that grew exponentially. In 70 years, from 1791 to 1860 , cotton production grew 500 fold - from 2 million pounds to around a billion pounds. ${ }^{64}$ By the time of the Civil War, U.S. economic growth reached its zenith with the aid of cotton. At its height in 1860, the U.S. dominated world production of cotton by producing almost 4 times as India, the world's second greatest producer of cotton at the time. Great Britain's need for cotton which grew from 5.19 million pounds in 1781 to 1.39 billion pounds in 1860 . Great Britain's imports of U.S. cotton rose from 487 million pounds in 1840 to 1.1 billion pounds in 1860. No one nation in the world imported more cotton than Great Britain. And no one provided more cotton to Great Britain than the U.S. Southern slave states from 1790 through $1860 .^{65}$

\footnotetext{
62 "African-American soldiers during the Civil War," Civil War and Reconstruction, Library of Congress, http://loc.gov/teachers/classroommaterials/presentationsandactivities/presentations/timeline/civilwar/aasold rs/ (accessed October 1, 2017).

${ }^{63}$ Ibid.

${ }^{64}$ Ed. Bruchey, Stuart. Cotton and the growth of the American Economy, 1790-1860 (New York: Harcourt, Brace \& World, 1967), 2.

${ }^{65}$ Stuart, Cotton and the growth of the American Economy, 7-40.
} 
A common but unsophisticated trope of antebellum U.S. historiography is that the South alone benefitted financially from cotton and slavery. A little known secret is the amount of prosperity cotton brought to Northern cities. But as Lincoln suggested, the North was complicit and enriched by the American slave institution. Financing fueled the cotton trade and New York capital provided it abundantly. New York itself was enriched by the cotton trade as it sold the cotton sent direct from the South to Europe aboard one of its vessels insured by a New York firm. ${ }^{66}$ Besides the strategic location of New York ports, entrepreneurs increasingly became involved in moving cotton to Europe. By 1860 the time of the Civil War New York served as the nexus of most of the cotton trade. This predictably brought much wealth and banking capital to the city. ${ }^{67}$

The fortune gained from cotton ironically actually helped the Union win the Civil War. The New York elite loaned the federal government the funds it needed after its reserves were nearly exhausted by the war. ${ }^{68}$ Revenue gained from the southern trade in cotton invariably made its way in the hands of their opponents and employed to hasten the South's demise. Thus, when Cheever accused the U.S. of making “oppression a source of their prosperity" cotton and its lucre made his point viable. That cotton profits gained from slavery were employed to defeat the slave apparatus that was the South is one of the ironies of the war. And that a prominent northern city like New York enriched itself from those same profits is a little discussed incongruity. For Cheever, this made the North and South equally responsible and accountable to divine retribution.

\footnotetext{
${ }^{66}$ Bruchey, Cotton and the growth of the American Economy, 226.

${ }^{67}$ Bruchey, Cotton and the growth of the American Economy, 226; Beckert, The Monied Metropolis, 117.

${ }^{68}$ Beckert, The Monied Metropolis, 117.
} 
Cheever demonstrated his vision for what he believed were the rights of all African Americans. His demand for emancipation and citizenship rights for African Americans was far more radical than the Federal government was willing to be in 1864 . Just a year earlier, Lincoln had issued the most massive emancipatory measure in the nation's history. Still, Lincoln's Emancipation Proclamation was a war order not meant for universal emancipation and citizenship for African Americans. It freed African Americans throughout the Confederacy but not those in the Border States. These slave Border States, which had remained loyal to the Union, were left unmolested by Lincoln's order lest the Union's balance of power be upset. In the winter of 1863 Lincoln and the Congress was in the process of thinking through preliminary Reconstruction plans. Lincoln offered his "Ten Percent Plan" which allowed rebel states to return to the Union provided ten percent of their voters took an oath of loyalty. While the plan abolished involuntary servitude, it did not require states to provide African Americans with suffrage. Louisiana, Arkansas and Tennessee were admitted to the Union in 1864 under the terms of Lincoln's plan. Of course, Cheever thought little of this plan perceiving its motive to be Union convenience rather than justice for African Americans.

When it came to African American citizenship rights Cheever was more radical than Lincoln or the so-called Radical Republicans - never mind the Confederacy. He challenged Congress to amend the Constitution to provide African Americans the right of suffrage though congressional proposals to amend the Constitution would be heretofore limited to emancipation. Years would pass before the question of citizenship or suffrage would not be even considered. The Wade-Davis Plan proposed in the summer of 1864 was the Radical Republicans' brand of justice. However, it fell well short of Cheever's 
challenge to them to provide the full rights of citizenship to African Americans. ${ }^{69}$

Cheever said:

Citizenship, under a republican form of government, carries with it the right of suffrage, irrespective of race or colour. If the right of suffrage be restricted, it must be on other grounds, and in regard to all persons equally. ${ }^{70}$

Cheever warned that leaving African Americans without the vote would allow their old masters in the South to continue their hegemony. ${ }^{71}$ Emancipation without citizenship was in reality "oppression" and de facto slavery. ${ }^{72}$

Chided by American abolitionists like Cheever, and to a lesser extent Lincoln and the Radical Republicans, Congress finally abolished slavery by passing the $13^{\text {th }}$ Amendment in January $31^{\text {st }}, 1865$. To commemorate the occasion, Congress and Lincoln invited Henry Highland Garnet to address Congress.

When Henry Highland Garnet addressed the House of Representatives on February 12, 1865 he reached a political peak. Invited to Capitol Hill to commemorate the passing of the $13^{\text {th }}$ Amendment, the former slave marked the first time an African American would speak before Congress. Personally for Garnet the speech also signaled a shift in his faith. Famous for his call for slave rebellion in his 1843 "An Address to the Slaves of the United States of America," a call inconsistent with the Exodus model of emancipation, Garnet was now before Congress 22 years later with a different message. On this occasion Garnet invoked the language of Exodus, and its imagery of providential

\footnotetext{
${ }^{69}$ Eric Foner, A Short History of Reconstruction, 1863-1877 (New York: Harper \& Row, 1984), 28-29.

${ }^{70}$ Cheever, "Rights of the Coloured Race," p. 21.

${ }^{71}$ Ibid, 22.

${ }^{72}$ Ibid.
} 
deliverance through divine retribution, to explain the cataclysmic Civil War and the subsequent emancipation of slaves. The evolution of Garnet's world view and faith can be tracked along key indicators beginning with where it stood first in 1842 , the dramatic shift in 1843 and its permutations at evident markers until his speech before Congress in 1865. By the time he addressed Congress, Garnet came to embrace the Exodus model of emancipation for African Americans that he had first rejected.

In 1842 Garnet was a man who believed that deliverance would come through non-violent means and that U.S. would respond to the cries of the oppressed. Garnet also believed that if this nation did not hear their cries, God would "hold trigger and sheath swords until the oppressor's cup is full." ${ }^{73}$ Somehow, for Garnet, God was in control in 1842 and African Americans needed only to wait on him for deliverance. By 1843, however, Garnet had a change of heart as his world view and faith saw no deliverance without slave rebellion. Whereas in 1842 he preached that God would "sheath the sword till the oppressor's cup is full," now, only a year later, the Reverend was prophesying to slaves that it was a sin against God for them to submit to slavery. Garnet proclaimed that "To such Degradation it is sinful in the Extreme for you to make voluntary Submission. The divine commandments you are in duty bound to reverence and obey. If you do not obey them, you will surely meet with the displeasure of the Almighty." 74 For Garnet, it was their "solemn and imperative duty to use every means, both moral, intellectual, and

\footnotetext{
${ }^{73}$ Henry Highland Garnet, "Speech Delivered at The Liberty Party Convention, Massachusetts, 1842," cited in Joel Schor, Henry Highland Garnet: A Voice of Black Radicalism in the Nineteenth Century (Westport, Connecticut and London, England, 1977), 143.

${ }^{74}$ Henry Highland Garnet, A memorial discourse: delivered in the hall of the House of Representatives, Washington City, D.C., on Sabbath, February 12, 1865, 47, Philadelphia, 1865, Slavery and Anti-Slavery, Gale, Florida International University (accessed March 9 2017).
} 
physical, that promises success." ${ }^{75}$ Moreover, Garnet held that Emancipation could not be achieved without the slaves shedding their blood to attain it. Any comparison to the Israelite slaves, Garnet argued, was futile for, "It is impossible, like the children of Israel, to make a grand exodus from the land of bondage. The Pharaohs are on both sides of the blood-red waters!"76

Garnet's declaration that there were "Pharaohs" on "both sides of the blood-red waters" represents his contention that both the North and the South were complicit in the oppression of blacks in America. For Garnet, this complicated any unilateral applications of the Exodus account to the African American experience. That slavery was legal in the South and protected throughout the land by the Constitution and the Fugitive Slave law of 1793 was testimony enough that African Americans could not compare themselves with the Israelites in a land rife with bondage. Appealing to their sense of manhood in view of their families being torn asunder by slavery, their "sons murdered," and their women “doomed to prostitution," Garnet urged his brothers in bondage to take a stand and "Strike for your lives and liberties," even if it meant death. ${ }^{77}$

This stance by Garnet represents the point in his life when he was not in step with the idea of slaves waiting on deliverance or a deliverer as the Israelites in the book of Exodus. As Eddie Glaude correctly argues in his Exodus! "Garnet rejected Exodus as a model for political action, claiming that it induced in slaves and freemen a passive

\footnotetext{
${ }^{75}$ Ibid.

${ }^{76}$ Ibid, 49.

${ }^{77}$ Ibid, 51.
} 
gradualism in which the group, like the children of Israel, waited for providential deliverance." ${ }^{78}$ To Garnet, the notion of providential deliverance by way of divine retribution, as is central to the Exodus emancipation model, was unacceptable. Garnet's stance was representative of the collective pain and disillusionment of many African Americans in the U.S. who were willing to take the matters of liberty into their own hands and force the issue of emancipation. ${ }^{79}$

There are, however, causal factors that contributed to Garnet's disillusionment. In 1842 the Supreme Court decision affirmed the Fugitive Slave Act of 1793 in its Prigg v. Pennsylvania decision, further bolstering the slave institution. Also in 1842, Rep. Joshua Giddings of Ohio was censured in the House of Representatives because of his antislavery activism. These, along with other factors, had worn on Garnet and brought about his radical 1843 address ${ }^{80}$ For the next 17 years after Garnet's speech, event after event spoke loud and clear that African Americans could not expect for freedom to come any time soon. The addition of Texas as a slave state in 1845 and the subsequent war with Mexico in 1846 signaled to African Americans that the slave power was getting stronger. The Compromise of 1850 made lands in the New Mexico and Utah Territories available to the slave power by popular sovereignty. Furthermore, the Fugitive Slave Act of 1850 made it legally binding on northern and southern state officials to return slaves to their masters. It also made it illegal for abolitionists to aid runaway slaves.

\footnotetext{
${ }^{78}$ Eddie Glaude, Jr., Exodus!: Religion, Race, and Nation in Early Nineteenth-Century Black America, (Chicago: University of Chicago Press, 2000), 146.

${ }^{79}$ Ibid.

${ }^{80} \mathrm{Ibid}, 147$.
} 
Signs, however, that the nation was convulsing because of slavery came with the Kansas-Nebraska Act of 1854. The subsequent strife known as "Bloody Kansas" unleashed violence manifesting the nation's willingness to decide the question of slavery through violence. "Bloody Kansas" was also the first indicator of the self-destructive clash that David Walker predicted in 1829. It signaled that the oppressors were beginning to turn against each other with, as he said, "sword in hand." ${ }^{81}$ The Supreme Court's Dred Scott decision, and Chief Justice Roger B. Taney's opinion, also served as a reminder that the black man "had no rights that the white man was bound to respect." 82 Furthermore, John Brown's failure at Harper's Ferry after “Bloody Kansas” in 1857 was yet another blow to the cause of freedom. Not only had he failed to seize the garrison, he had failed to ignite the slave rebellion and emancipation he hoped to incite. He and his cohorts were captured, tried, convicted and condemned to death.

But if Garnet's dream of freedom achieved by slave uprising was dashed by Brown's failure, the debacle somehow gave rise to thoughts of emancipation through a higher power. At a memorial on December 2, 1859 for the executed Brown, Garnet began to speak in terms of providential deliverance through divine retribution for a guilty nation. He proclaimed that he saw "the dreaded truth, written as by the finger of Jehovah-'For the sins of this nation there is not atonement without the shedding of

\footnotetext{
${ }^{81}$ United States, Supreme Court, The case of Dred Scott in the United States Supreme Court: the full opinions of Chief Justice Taney and Justice Curtis, and abstracts of the opinions of the other judges, with an analysis of the points ruled, and some concluding observations, New York, 1857, 9, Slavery and AntiSlavery, Gale, Florida International University (accessed March 9, 2017).

${ }^{82}$ David Walker, Walker's appeal: with a brief sketch of his life, New-York, 1848, 14, Slavery and AntiSlavery, Gale, Florida International University (accessed March 9, 2017).
} 
blood." $" 83$ Within a year and a half, the nation was embroiled in Civil War. There is evidence that some African Americans saw the onset of the Civil War as divine providence and in millennial terms, believing the opportunity for freedom was close at hand. ${ }^{84}$ And, if African Americans saw providence they also saw one more thing-a golden opportunity. Garnet and Douglass were among the first to set about recruiting black soldiers. ${ }^{85}$

As the war came to a close, Abraham Lincoln and Congress turned to the business of universal emancipation. The $13^{\text {th }}$ Amendment abolishing slavery was passed and Congress unanimously asked Garnet to speak on the occasion. That Garnet was invited, and not Douglass, indicates the level of regard Garnet had earned in his time. No other black man had ever received such an honor in the U.S. And Garnet did not disappoint. His speech on Sunday, February 14, 1865 gained outstanding reviews from several newspapers. ${ }^{86}$ Most significantly, the speech signaled Garnet's evolutionary faith. In it he used the imagery of Exodus and its doctrine of providential deliverance through divine retribution to explain the cataclysm from which the nation was now emerging. Whereas in 1843 he saw emancipation being in the hands of slave agency and called on slave resistance and rebellion as the way to freedom, now twenty-two years later, he saw something of the hand of God in what had transpired. ${ }^{87}$ Whereas in 1843 he rejected

\footnotetext{
${ }^{83}$ Garnet, Weekly Anglo-African, December 10, 1859 cited in Ofari's, "Resistance," 107, footnote 7.

${ }^{84}$ Orville Vernon Burton, The Age of Lincoln (New York: Hill and Wang, 2007), 237.

${ }^{85}$ Ofari, "Resistance," 109.

${ }^{86}$ Schor, H.H. Garnet, 209.

${ }^{87}$ Schor, H.H. Garnet, 210.
} 
Exodus as a model for emancipation, now he was alluding to the language of Exodus to explain in prophetic terms what had transpired in the last 4 years. Garnet declared:

Moses, the greatest of all lawgivers and legislators, said, while his face was yet radiant with the light of Sinai: "whoso stealeth a man, and selleth him, or if he be found in his hand, he shall surely be put to death." The destroying angel has gone forth through his land to execute the fearful penalties of God's broken law. ${ }^{88}$ His reference to the "destroying angel" was a reference to the Exodus account. In

that account the Israelite slaves, as it were, gained their freedom from Egypt after the $10^{\text {th }}$ and final plague. In that plague the "destroying angel" in retributive justice, went through the land and killed the firstborn of each Egyptian household. For Garnet the "hand of God" had worked in the Civil War and made possible the "miracle" of black soldiers marching on the Confederacy. In all this the "destroying angel" had done its work to emancipate his people. Now, for Garnet, the passing of the $13^{\text {th }}$ Amendment was Congress' humble way to prevent the "destroying angel" from returning to mete out divine retribution on future generations. Garnet declared that, "The Representatives of the nation have bowed with reverence to the Divine edict, and laid the axe at the root of the tree, and thus saved succeeding generations from the guilt of oppression, and from the wrath of God. ${ }^{89}$ Garnet closed his speech with a poem from Exodus further demonstrating that he framed the African American experience in Exodus language. He had come full circle from rejecting the Exodus model for freedom to fully embracing its message of providential deliverance for African Americans through divine retribution.

\footnotetext{
${ }^{88}$ Henry Highland Garnet, A Memorial Discourse: Delivered in the hall of the House of Representatives, Washington City, D.C., on Sabbath, February 12, 1865, Philadelphia, 1865, 82, Slavery and Anti-Slavery, Gale, Florida International University, (accessed March 9, 2017).

${ }^{89}$ Ibid.
} 
Less than a month after Garnet's address, it was Lincoln's turn to address the American people for the final time in his Second Inauguration, there was a wealth of literature in the national discourse to frame the Civil War as an act of divine retribution. Pastors, chaplains and even Congressmen had become familiar with the biblical language that defined American slavery as a national sin. Congress had hosted at least two preachers that spoke at length about the war as an act of God against American oppression. By the time Lincoln spoke much had already been said in the public square and in the nation's places of worship about the nation's ample "blood and the treasure" that had been lost because of the national sin of American slavery. By the time Lincoln addressed the nation, thousands of families had mourned their husbands, fathers, brothers and sons. It was up to the Commander-In-Chief to put on an oratorical robe of a different color and act as Pastor-In-Chief to comfort the grieving nation.

To comfort the hurting nation Lincoln invoked the biblical language employed by pastors throughout the Union to explain why so much blood and treasure had to be expended to restore freedom to the nation in his second inaugural speech. Lincoln reminisced about his first inauguration during which he urged the southern states to remain within the Union to no avail. He lamented that while all "dreaded" and sought to "avert" war, there were those who were willing to "make war" to spread American slavery while others were willing to "accept" war to save the Union. ${ }^{90}$ And so the Civil War came. What troubled Lincoln was that both sides "read the same Bible and pray to

\footnotetext{
${ }^{90}$ Abraham Lincoln, and Roy P. Basler, Abraham Lincoln: His Speeches and Writings (Millwood, New York: Kraus Reprint Co, 1976), 792-793.
} 
the same God." ${ }^{\text {"1 }}$ Lincoln found it "strange" that anyone would "dare to ask a just God's assistance in wringing their bread from other men's faces." ${ }^{92}$ In this regard, Lincoln was skeptical about the religious conflict of interest of a people that prayed to God to oppress another part of his creation. Despite his skepticism, Lincoln surmised that "the prayers of both could not be answered fully." 93 God stood apart from the prayers and purposes of all men, regardless of whether from the North or the South. As Lincoln related it, "The Almighty has His own purposes." 94 The war for Lincoln, therefore, had a purpose that transcended the religious beliefs of the North and the South. The war was a "woe" that came "because of offenses" that is, because of sin. Lincoln quoted Jesus' words warning of the consequences of sin. "Woe unto the world because of offenses; for it must needs be that offenses come, but woe to that man by whom the offense cometh." 95

Lincoln understood the South was not the only part of the nation that was culpable in the enslavement of millions of African Americans. As abolitionists like Cheever and Garnet had already leveled the accusation and northern pastors accepted responsibility for American oppression, to say nothing of southern oppression. For Lincoln, God was intent of delivering a retributive lesson on the whole nation, not just to the South. "He gives to both North and South this terrible woe due to those by whom the offense came." ${ }^{96}$

\footnotetext{
${ }^{91}$ Ibid.

${ }^{92}$ Ibid.

${ }^{93}$ Ibid.

${ }^{94}$ Ibid.

${ }^{95}$ Ibid; biblical reference in Matthew 18:7.

${ }^{96}$ Ibid.
} 
Mindful that the war lasted interminably more than the nation hoped, Lincoln hoped and "fervently" prayed "that this mighty scourge of war may speedily pass away." ${ }^{\prime 97}$ It is here that he gently explained to the nation that they were dealing with a God working justice for African Americans against both the North and the South. And, God would not relent until justice was served. As the United States had extracted from enslaved African Americans much blood and treasure from the sweat of African American brow, so God was extracting an equal amount of blood and treasure from the whole nation. "Yet, if God wills," Lincoln explained, "that [the war] continue until all the wealth piled by the bondman's two hundred and fifty years of unrequited toil shall be sunk, and until every drop of blood drawn with the lash shall be paid by another drawn with the sword, as was said three thousand years ago, so still it must be said 'the judgments of the Lord are true and righteous altogether." ${ }^{, 98}$ For Lincoln, God had passed judgment on the United States of America and American slavery, and the war would go on until every drop of African American blood was accounted for and all the wealth due to the Africans was expended. For Lincoln, therefore, divine justice for what the enslaved endured was 850,000 casualties and 1.4 trillion dollars lost. A heavy price. It was for Americans to quietly and humbly pick up the pieces and "bind up the nation's wounds" showing "malice toward none" and "charity for all." ${ }^{99}$ Lincoln called on the nation "to care for him who shall have borne the battle and for his widow and his orphan." ${ }^{100}$ A nation that widowed and

\footnotetext{
${ }^{97}$ Ibid.

${ }^{98}$ Ibid.

${ }^{99}$ Ibid.

${ }^{100}$ Ibid.
} 
orphaned millions of enslaved African Americans, would now have to care for thousands of widows and orphans created by the war to end American slavery. Beyond that, the nation would need to "bind up its wounds" build "a just and lasting peace," within and without. $^{101}$

${ }^{101}$ Ibid. 


\section{REFERENCES}

\section{Primary Sources: Published Works and Letters}

Adams, W. E. The slaveholders' war: an argument for the North and the Negro. Manchester, 1863. Slavery and Anti-Slavery. Gale. Florida International University. (accessed September 30, 2017).

Anti-Slavery Convention of American Women (1st: 1837: New York, N.Y.). An appeal to the women of the nominally free states: issued by an Anti-Slavery Convention of American Women: held by adjournments from the 9th to the 12th of May, 1837, 2nd ed. Boston, 1838. Slavery and Anti-Slavery. Gale. Florida International University. (accessed October 1, 2017)

Benezet, Anthony to Granville Sharp, May 14, 1772. In Memoirs of Granville Sharp, ed. Prince Hoare. London, 1820.

Benezet, Anthony. A caution and warning to Great Britain and her colonies, in a short representation of the calamitous state of the enslaved Negroes in the British dominions: collected from various authors and submitted to the serious consideration of all, more especially of those in power by Ant. Benezet. Philadelphia, 1766. Slavery and AntiSlavery. Gale. Florida International University (accessed March 25, 2016).

Bittinger, J. B. (Joseph Baugher). A sermon, preached before the Presbyterian churches of Cleveland: on the national fast day, September 26, 1861. Cleveland, 1861. Slavery and Anti-Slavery. Gale. Florida International University. (accessed September 29, 2017).

Bourne, George. Condensed anti-slavery Bible argument. New York.1845. Slavery and Anti-Slavery. Gale. Florida International University. (accessed October 1, 2017);

. Picture of slavery in the United States of America, Middletown, Conn., 1834. Slavery and Anti-Slavery. Gale. Florida International University (accessed July 10, 2016).

. Slavery illustrated in its effects upon women and domestic society. Boston, 1837. Slavery and Anti-Slavery. Gale. Florida International University. (accessed April 3, 2017).

. The abrogation of the Seventh commandment, by the American churches. New-York, 1835. Slavery and Anti-Slavery. Gale. Florida International University. (accessed April 3, 2017).

. The book and slavery irreconcilable: with animadversions upon Dr.

Smith's philosophy. Philadelphia, 1816. Slavery and Anti-Slavery. Gale. Florida International University. (accessed July 8, 2016). 
Bourne, Theodore. Rev. George Bourne: the pioneer of American antislavery [Louisville, Ky.], [1882]. Slavery and Anti-Slavery. Gale. Florida International University (accessed October 22, 2016).

Branagan, Thomas. A preliminary essay, on the oppression of the exiled sons of Africa: consisting of animadversions on the impolicy and barbarity of the deleterious commerce and subsequent slavery of the human subspecies ... (Philadelphia, 1804) Slavery and Anti-Slavery. Gale. Florida International University. (accessed July 5, 2016).

. Serious remonstrances, addressed to the citizens of the northern states, and their representatives: being an appeal to their natural feelings \& common sense: consisting of speculations and animadversions, on the recent revival of the slave trade, in the American republic: with an investigation relative to the consequent evils resulting to the citizens of the northern states from that event Interspersed with a simplified plan for colonizing the free negroes of the northern, in conjunction with those who have or may emigrate from the southern states, in a distant part of the national territory : considered as the only possible means of avoiding the deleterious evils attendant on slavery in a republic (Philadelphia, 1805). Slavery and Anti-Slavery. Gale. Florida International University. (accessed July 5, 2016).

. The penitential tyrant, or, Slave trader reformed: a pathetic poem, in four cantos. $2 d$ ed., enl. ... (New-York, 1807) Slavery and Anti-Slavery. Gale. Florida International University. (accessed July 5, 2016).

Cheever, George B. "Discourse by Rev. Dr. Cheever.” September 27, 1861. New York Times (1857-1922) Retrieved from http://ezproxy.fiu.edu/login?url=https://searchproquest-com.ezproxy.fiu.edu/docview/91593652? accountid=10901 (accessed September 30, 2017).

. Rights of the Coloured Race to Citizenship and Representation: And the Guilt and Consequences of Legislation against Them, a Discourse Delivered in the Hall of Representatives of the United States, in Washington, D.C., May 29, 1864, New York: Francis \& Loutrel, 1864.

http://find.galegroup.com/openurl/openurl?url_ver=Z39.88-

2004\&url_ctx_fmt=info:ofi/fmt:kev:mtx:ctx\&res_id=info:sid/gale:NCCO\&ctx_enc=info: ofi:enc:UTF-

8\&rft_val_fmt=info:ofi/fmt:kev:mtx:unknown\&rft.artnum=CSEGLH154227024\&req_da $\mathrm{t}=$ info:sid/gale:ugnid. (accessed October 1, 2017).

The fire and hammer of God's word against the sin of slavery: speech of George B. Cheever, D.D., at the anniversary of the American Abolition Society. May, 1858. New-York. 1858. Slavery and Anti-Slavery. Gale. Florida International University. (accessed October 1, 2017). 
Chew, John H. God's judgments teaching righteousness: a sermon delivered on the national fast day, January 4, 1861, in St. Matthew's parish. Prince George's County, Md. Washington, 1861. Slavery and Anti-Slavery. Gale. Florida International University. (accessed September 28, 2017).

Clark, Frederick Gorham. Gold in the fire, our national position: a sermon, preached ... on Thanksgiving Day, Nov. 27th1862. New-York, 1862. Sabin Americana, Gale, Cengage Learning (accessed September 29, 2017).

Clarkson, Thomas. The History of the Rise, Progress and Accomplishment of the Abolition of the Slave-Trade by the British Parliament. New York: John S. Taylor, 1936.

Cornish, Samuel E. and Samuel Eli, The colonization scheme considered: in its rejection by the colored people, in its tendency to uphold caste, in its unfitness for Christianizing (Newark, NJ: 1840) Sabin Americana, Gale, Cengage Learning. (accessed April 18, 2017).

Douglass, Frederick. Narrative of the life of Frederick Douglass: an American slave. Boston, 1846. Slavery and Anti-Slavery. Gale. Florida International University. (accessed October 1, 2017).

Duffield, George. The God of our fathers: an historical sermon preached in the Coates' Street Presbyterian Church, Philadelphia, on Fast Day, January 4, 1861. Philadelphia (Philadelphia), 1861. Sabin Americana. Gale. Cengage Learning. (accessed September 28, 2017).

Furness, William Henry. A word of consolation for the kindred of those who have fallen in battle: a discourse delivered September 28, 1862. Philadelphia, 1862. Sabin Americana. Gale. Cengage Learning. (accessed September 29, 2017).

Garnet, Henry Highland. "Speech Delivered at The Liberty Party Convention, Massachusetts, 1842," in Joel Schor, Henry Highland Garnet: A Voice of Black Radicalism in the Nineteenth Century. Westport, Connecticut and London, England, 1977.

. A memorial discourse: delivered in the hall of the House of Representatives, Washington City, D.C., on Sabbath, February 12, 1865. Philadelphia, 1865. Slavery and Anti-Slavery. Gale. Florida International University. (accessed March 9, 2017).

Garrison, William Lloyd. "Anti-Slavery Celebration of the Fourth of July, 1856," William Lloyd Garrison, President, National Anti-Slavery Standard (New York, New York, United States). Saturday, July 12, 1856; Issue 8. Slavery and Anti-Slavery. Gale. Florida International University (accessed October 1, 2017). 
. Three unlike speeches. New York, 1862. Slavery and Anti-

Slavery. Gale. Florida International University. (accessed September 29, 2017).

Gilbert, Olive. Narrative of Sojourner Truth: a northern slave, emancipated from bodily servitude by the State of New York, in 1828: with a portrait. Boston, 1850. Slavery and Anti-Slavery. Gale. Florida International University. (accessed October 1, 2017).

Grimké, Angelina Emily, and Charles Wilbanks. Walking by Faith: The Diary of Angelina Grimké, 1828-1835. Columbia: University of South Carolina Press, 2003. Grimké, Angelina Emily Appeal to the Christian women of the South [s.1.], [1836?]. Slavery and Anti-Slavery. Gale. Florida International University. (accessed April 3, 2017).

Grimké, Sarah Moore. An epistle to the clergy of the southern states, [New York], [1836?], Slavery and Anti-Slavery. Gale. Florida International University. (accessed April 3, 2017).

Hopkins, Samuel. A dialogue concerning the slavery of the Africans: shewing it to be the duty and interest of the American states to emancipate all their African slaves: with an address to the owners of such slaves: dedicated to the honourable the Continental congress: to which is prefixed, the institution of the Society, in New-York, for promoting the manumission of slaves, and protecting such of them as have been, or may be, liberated ... Hazard pamphlets; v. 70, no. 3 Norwich [Conn.], 1776. Slavery and AntiSlavery. Gale. Florida International University. (accessed March 25, 2016).

Hunt, Ezra Mundy. The war and its lessons. New York, 1862. Sabin Americana. Gale. Cengage Learning. (accessed September 29, 2017.

Julian, George Washington. The cause and cure of our national troubles: speech of Hon. Geo. W. Julian, of Indiana, delivered in the House of representatives, Tuesday, ... Washington, D.C., 1862. Sabin Americana. Gale. Cengage Learning. (accessed September 29, 2017).

Kirkland, Charles P. (Charles Pinckney). The destiny of our country. New York, 1864. Slavery and Anti-Slavery. Gale. Florida International University. (accessed September 30, 2017).

Lay, Benjamin. All slave-keepers that keep the innocent in bondage, apostates pretending to lay claim to the pure \& holy Christian religion; of what congregation so ever; but especially in their ministers, by whose example the filthy leprosy and apostacy is spread far and near; it is a notorious sin, which many of the true Friends of Christ, and his pure truth, called Quakers, has been for many years, and still are concern'd to write and bear testimony against; as a practice so gross \& hurtful to religion, and destructive to government, beyond what words can set forth, or can be declared of by men or angels, 
and yet lived in by ministers and magistrates in America. The leaders of the people cause them to err. Written for a general service, by him that truly and sincerely desires the present and eternal welfare and happiness of all mankind, all the world over, of all colours, and nations, as his own soul; Benjamin Lay. Philadelphia, 1737 [i.e., 1738]. Slavery and Anti-Slavery. Gale. Florida International University (accessed March 25, 2016).

Lincoln, Abraham and Roy P. Basler. Abraham Lincoln: His Speeches and Writings. Millwood, New York: Kraus Reprint Co, 1976.

Lord, Charles Eliphalet. Slavery, secession and the Constitution: An appeal to our country's loyalty. Boston, 1864. Slavery and Anti-Slavery. Gale. Florida International University. (accessed September 30, 2017).

Moore, Henry D. Our country--its sin and its duty: A discourse: on the occasion of the national fast, September 26th, 1861. Portland [ME], 1861.Slavery and Anti-Slavery. Gale. Florida International University. (accessed September 29, 2017).

Moncrieff, Rev. Sir Henry. "Speech of Rev. Sir Henry Moncrieff," National Anti-Slavery Standard (New York, New York, United States), Saturday, March 23, 1861. Issue 45. Slavery and Anti-Slavery. Gale. Florida International University. (accessed September 28, 2017).

May, Samuel J. “A Sermon on Our Civil War,” The Liberator (Boston, Massachusetts), Friday, May 24, 1861. 84. Issue 21. Slavery and Anti-Slavery. Gale. Florida International University (accessed September 28, 2017).

. The fugitive slave law and its victims, Rev and enlarged ed., New York, 1861. Slavery and Anti-Slavery, Gale, Florida International University (accessed September 29, 2017).

Noble, Frederick A. Blood the price of redemption: A Thanksgiving discourse delivered in the House of Hope, Nov. 27, 1862. St. Paul, 1862. Slavery and Anti-Slavery. Gale. Florida International University. (accessed September 29, 2017).

Northup, Solomon. Twelve years a slave: narrative of Solomon Northup, a citizen of New-York, kidnapped in Washington City in 1841, and rescued in 1853, from a cotton plantation near the Red River, in Louisiana, Auburn, 1853. Slavery and Anti-Slavery. Gale. Florida International University. (accessed February 28, 2017).

Oakey, P. D. The war, its origin, purpose, and our duty respecting it: a sermon preached in the First Presbyterian Church, Jamaica, L.I., on the day of ... New-York, 1861. Sabin Americana. Gale. Cengage Learning. (accessed September 29, 2017). 
Philadelphia Female Anti-slavery Society. Twenty-eighth annual report of the Philadelphia Female Anti-slavery Society. Philadelphia, 1862. Slavery and Anti-Slavery. Gale. Florida International University. (accessed September 29, 2017).

Rice David. Slavery inconsistent with justice and good policy, proved by a speech delivered in the convention, held at Danville, Kentucky by the Rev. David Rice, London, 1793. Slavery and Anti-Slavery. Gale. Florida International University. (accessed June 29, 2016).

Sandiford, Ralph. The mystery of iniquity; in a brief examination of the practice of the times, by the foregoing and the present dispensation: whereby is manifested how the Devil works in the mystery, which none can understand and get the victory over but those that are armed with the light ... Unto which is added in the postscript, the injury this trading in slaves doth the commonwealth, humbly offer'd to all of a publick spirit. The second edition, with additions. [Five lines of Scripture texts]. [Philadelphia], anno 1730. Slavery and Anti-Slavery. Gale. Florida International University. (accessed March 25, 2016).

Sharp, Granville. An essay on slavery: proving from Scripture its inconsistency with humanity and religion; in answer to a late publication, entitled, 'The African trade for negro slaves shewn to be consistent with principles of humanity, and with the laws of revealed religion.' Burlington [NJ], 1773. Slavery and Anti-Slavery. Gale. Florida International University. (accessed March 25, 2016).

. The law of retribution, or, A serious warning to Great Britain and her colonies: founded on unquestionable examples of God's temporal vengeance against tyrants, slave-holders, and oppressors ... London, 1776. Slavery and Anti-Slavery. Gale. Florida International University. (accessed March 25, 2016).

. The just limitation of slavery in the laws of God, compared with the unbounded claims of the African traders and British American slaveholders London, 1776. Slavery and Anti-Slavery. Gale. Florida International University. (accessed March 25, 2016).

Sarter, Caesar. "Address to Those who are Advocates for Holding the Africans in Slavery," in Carol Sue Humphrey, Voices of revolutionary America: contemporary accounts of daily life (Santa Barbara, California: Greenwood, 2011).

Stearns, William A. (William Augustus). Necessities of the war and the conditions of success in it: a sermon preached in the village church, before the college and the united congregations of the town of Amherst, Mass., on the national fast day. Thursday, September 26, 1861. 2nd ed., for the college. Amherst, Mass., 1861. Slavery and AntiSlavery. Gale. Florida International University. (September 29, 2017). 
Stockton, T. H. (Thomas Hewlings). Address by Thomas H. Stockton, Chaplain U.S.H.R.: delivered in the hall of the House of Representatives, on the day of National Humiliation, Fasting, and Prayer, Friday, January 4, 1861. Washington, [D.D], 1861. Slavery and Anti-Slavery. Gale. Florida International University. (accessed September 28, 2017).

Sunderland, La Roy. The Testimony of God against Slavery, Or A Collection of Passages from the Bible, Which Show the Sin of Holding Property in Man; with Notes. St. Clair Shores. Michigan: Scholarly Press, 1970.

Stewart, M. W. Meditations from the pen of Mrs. Maria W. Stewart: (Widow of the late James W. Stewart) now matron of the Freedman's hospital, and presented in 1832 to the First African Baptist church and society of Boston, Mass. Washington, 1879.

. Productions of Mrs. Maria W. Stewart: presented to the First African

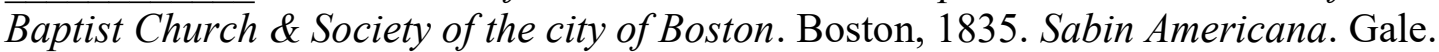
Cengage Learning. (accessed April 18, 2017).

Stowe, Harriet Beecher. The key to Uncle Tom's cabin: presenting the original facts and documents upon which the story is founded: together with corroborative statements verifying the truth of the work. Boston, 1854. Slavery and Anti-Slavery. Gale. Florida International University. (accessed October 1, 2017).

Thompson, George. American slavery: a lecture delivered in the Music Hall, Store Street, Monday, Dec. 13th, 1852 by George Thompson. London. 1853. Slavery and Anti-Slavery. Gale. Florida International University. (accessed October 1, 2017).

Thompson, Thomas. The African trade for Negro slaves: shewn to be consistent with principles of humanity, and with the laws of revealed religion. Canterbury, [1772?]. Slavery and Anti-Slavery. Gale. Florida International University. (accessed March 25, 2016).

Walker, David and Henry Highland Garnet. Walker's appeal: with a brief sketch of his life. New York: Printed by J.H. Tobitt, 1830. Slavery and Anti-Slavery. Gale. Florida International University. (accessed April 18, 2017).

Walker, David. Walker's appeal: with a brief sketch of his life. New-York, 1848. Slavery and Anti-Slavery. Gale. Florida International University. (accessed March 9, 2017).

Webb, Richard Davis. The life and letters of Captain John Brown, who was executed at Charlestown, Virginia, Dec. 2, 1859, for an armed attack upon American slavery: with notices of some of his confederates, edited by Richard D. Webb. London, 1861. Slavery and Anti-Slavery. Gale. Florida International University. (accessed October 1, 2017). 
Weld, Theodore Dwight. The Bible against slavery: an inquiry into the patriarchal and Mosaic systems on the subject of human rights. New York, 1837. Slavery and AntiSlavery. Gale. Florida International University. (accessed October 1, 2017).

Weld, Theodore Dwight, Angelina Emily Grimké, Sarah Moore Grimké, Gilbert Hobbs Barnes, and Dwight Lowell Dumond. Letters of Theodore Dwight Weld, Angelina Grimké and Sarah Grimké, 1822-1844. Gloucester, Mass: P. Smith, 1965.

Woolman, John. Considerations on the keeping of Negroes: recommended to the professors of Christianity of every denomination. Tract Association of Friends (Series); no. 85. Philadelphia, [18--?]. Slavery and Anti-Slavery. Gale. Florida International University. (accessed March 25, 2016).

\section{Secondary Sources: Books}

Abzug, Robert H. Cosmos Crumbling: American Reform and the Religious Imagination. New York: Oxford University Press, 1994.

Adams, Catherine, and Elizabeth H. Pleck. Love of Freedom: Black Women in Colonial and Revolutionary New England. Oxford: Oxford University Press, 2010.

Andrews, William L., Jarena Lee, Zilpha Elaw, and Julia A. J. Foote. Sisters of the Spirit: Three Black Women's Autobiographies of the Nineteenth Century. Bloomington: Indiana University Press, 1986.

Anstey, Roger. The Atlantic Slave Trade and British Abolition, 1760-1810. New Jersey: Humanities Press, 1975.

Bailyn, Bernard. The Idealogical Origins of the American Revolution. Cambridge, MA.: Harvard University Press, 1967.

Banner, Stuart. How the Indians Lost Their Land: Law and Power on the Frontier. Cambridge, Mass: Belknap Press of Harvard University Press, 2005.

Baptist, Edward E. The Half Has Never Been Told: Slavery and the Making of American Capitalism. 2014.

Barnes, Gilbert Hobbs. The Antislavery Impulse, 1830-1844. Gloucester, Mass: P. Smith, 1973.

Bay, Mia. The White Image in the Black Mind: African-American Ideas About White People, 1830-1925. New York: Oxford University Press, 2000.

Beckert, Sven, and Seth Rockman. Slavery's capitalism: a new history of American economic development. 2016. 
Belohlavek, John M. Andrew Jackson: Principle and Prejudice. 2016.

Berkin, Carol. Civil War Wives: The Lives and Times of Angelina Grimké Weld, Varina Howell Davis, and Julia Dent Grant. New York: Alfred A. Knopf, 2009.

Berlin, Ira. Generations of Captivity: A History of African-American Slaves. Cambridge, Mass: Belknap Press of Harvard University Press, 2003.

1998. . Many Thousands Gone: The First Two Centuries of Slavery in North America.

Berry, Daina Ramey. The Price for Their Pound of Flesh: The Value of the Enslaved from Womb to Grave in the Building of a Nation. 2017.

Birney, Catherine H. The Grimké Sisters; Sarah and Angelina Grimké: The First American Women Advocates of Abolition and Woman's Rights. Westport, Conn: Greenwood Press, 1969.

Bradley, K. R. Slavery and Society at Rome. Cambridge [England]: Cambridge University Press, 1994.

Breen, T. H., and Stephen Innes. Myne Owne Ground: Race and Freedom on Virginia's Eastern Shore, 1640-1676. New York: Oxford University Press, 1980.

Brookhiser, Richard. James Madison. New York, NY: Basic Books, 2011.

Brown, Christopher Leslie. Moral Capital: Foundations of British Abolitionism. Chapel Hill: Published for the Omohundro Institute of Early American History and Culture, Williamsburg, Virginia, by the University of North Carolina Press, 2006.

Brown, Vincent. The Reaper's Garden: Death and Power in the World of Atlantic Slavery. Cambridge, Mass: Harvard University Press, 2008.

Browne, Stephen H. Angelina Grimké: Rhetoric, Identity, and the Radical Imagination. East Lansing: Michigan State University Press, 1999.

Bruchey, Stuart Weems. Cotton and the Growth of the American Economy, 1790-1860; Sources and Readings. New York: Harcourt, Brace \& World, 1967.

Burrough, Bryan. Public Enemies: America's Greatest Crime Wave and the Birth of the FBI, 1933-34. New York: Penguin Press, 2004.

Burton, Orville Vernon. The Age of Lincoln. New York: Hill and Wang, 2007. 
Cahill, Kevin, and Lene Johannessen. Considering Class: Essays on the Discourse of the American Dream. Münster: Lit, 2007.

Cameron, Christopher. To Plead Our Own Cause: African Americans in Massachusetts and the Making of the Antislavery Movement. 2014.

Carp, Benjamin L. Rebels Rising: Cities and The American Revolution. Oxford: Oxford University Press, 2007.

Ceplair, Larry, Angelina Emily Grimké, and Sarah Moore Grimké. The Public Years of Sarah and Angelina Grimké: Selected Writings, 1835-1839. New York: Columbia University Press, 1989.

Chesebrough, David B. "God Ordained This War": Sermons on the Sectional Crisis, 1830-1865. Columbia, S.C.: University of South Carolina Press, 1991.

Christie, John W., Dwight Lowell Dumond, and George Bourne. George Bourne and the Book and Slavery Irreconcilable. Wilmington: Historical Society of Delaware, 1969.

Christopher, Emma, Cassandra Pybus, and Marcus Rediker. Many Middle Passages: Forced Migration and the Making of the Modern World. Berkeley. University of California Press, 2007.

Conforti, Joseph. Samuel Hopkins and the New Divinity Movement. New Haven, Conn.: Yale University Press, 2007.

Cooper, Charles R. Chronological and Alphabetical Record of the Engagements of the Great Civil War With the Casualties On Both Sides And Full And Exhaustive Statistics And Tables of the Army And Navy, Military Prisons, National Cemeteries, Etc., Etc., (Milwaukee, Wis.: The Caxton press, 1904) Hathi Trust Digital Library. (accessed September 30, 2017).

Copeland, David A. The Antebellum Era: Primary Documents on Events from 1820 to 1860. Westport, Conn: Greenwood Press, 2003.

Coupland, Sir Reginald. The British Anti-Slavery Movement. London: Frank Cass \& Co. LTD, 1933.

Davis, David Brion. Challenging the Boundaries of Slavery. Cambridge, Mass: Harvard University Press, 2003.

. Inhuman Bondage: The Rise of Fall of Slavery in the New World. New York City, NY: Oxford University Press, 2006. 
. The Problem of Slavery in the Age of Revolution, 1770-1823. Ithaca, N.Y.: Cornell University Press, 1975.

D'Emilio, John, and Estelle B. Freedman. Intimate Matters: A History of Sexuality in America. Chicago: University of Chicago Press, 1997.

Deyle, Steven. Carry Me Back: The Domestic Slave Trade in American Life. New York: Oxford University Press, 2005.

Drescher, Seymour. Abolition: a history of slavery and antislavery. Cambridge:

Cambridge University Press, 2009.

Dumond, Dwight Lowell. Antislavery: The Crusade for Freedom in America. Ann Arbor: University of Michigan Press, 1961.

Egerton, Douglas R. He Shall Go Out Free: The Lives of Denmark Vesey. Lanham, Md: Rowman \& Littlefield, 2004.

Ericson, David F. The Debate Over Slavery: Antislavery and Proslavery Liberalism in Antebellum America. New York: New York University Press, 2000.

Ernest, John. Liberation Historiography: African American Writers and the Challenge of History, 1794-1861. Chapel Hill: University of North Carolina Press, 2004.

Ernst, Robert. Rufus King, American Federalist. Chapel Hill: Published for the Institute of Early American History and Culture at Williamsburg, Va., by University of North Carolina Press, 1968.

Faust, Drew Gilpin. The Ideology of Slavery: Proslavery thought in the Antebellum South, 1830-1860. Baton Rouge: Louisiana State University Press, 1981. . This Republic of Suffering: Death and the American Civil War. New York: Alfred A. Knopf, 2008.

Fenn, Elizabeth A. Pox Americana: The Great Smallpox Epidemic of 1775-82. New York: Hill and Wang, 2001.

Finkelman, Paul, and Donald R. Kennon. Congress and the Emergence of Sectionalism: From the Missouri Compromise to the Age of Jackson. Athens, Ohio: Ohio University Press, 2008.

Foner, Eric. A Short History of Reconstruction, 1863-1877. New York: Harper \& Row, 1984. 
Fogel, Robert William. Without Consent or Contract: The Rise and Fall of American Slavery. New York: Norton, 1989.

Ford, Lacy K. Deliver Us from Evil: The Slavery Question in the Old South. Oxford [England]: Oxford University Press, 2009.

Foreman, Grant. Indian Removal; The Emigration of the Five Civilized Tribes of Indians. Norman: University of Oklahoma Press, 1953.

Freehling, William W. The Reintegration of American History: Slavery and the Civil War. New York: Oxford University Press, 1994.

. The Road to Disunion. New York: Oxford University Press, 1990. Gates, Henry Louis. The Classic Slave Narratives. New York, N.Y., U.S.A.: Penguin, 1987.

Gay, Sydney Howard. James Madison. New Rochelle, N.Y.: Arlington House, 1970.

Gibbs, Jenna M. Performing the Temple of Liberty: Slavery, Theater, and Popular Culture in London and Philadelphia, 1760-1850. Baltimore: Johns Hopkins University

Press, 2014.

Glancy, Jennifer A. Slavery in Early Christianity. Oxford: Oxford University Press, 2002. Greene Arnold, Samuel. History of the state of Rhode Island and Providence plantations, Spartanburg, S.C.: Reprint Co., 1859.

Gudmestad, Robert H. A Troublesome Commerce: The Transformation of the Interstate Slave Trade. Baton Rouge: Louisiana State University Press, 2003.

Guyatt, Nicholas. Providence and the Invention of the United States, 1607-1876. New York: Cambridge University Press, 2007.

Hall, Stephen G. A Faithful Account of the Race: African American Historical Writing in Nineteenth-Century America. Chapel Hill: University of North Carolina Press, 2009.

Harrill, James Albert. Slaves in the New Testament: Literary, Social, and Moral Dimensions. Minneapolis: Fortress Press, 2006.

Hinks, Peter P. To Awaken My Afflicted Brethren: David Walker and the Problem of Antebellum Slave Resistance. University Park, Pa: Pennsylvania State University Press, 1997.

Hoare, Prince. Memoirs of Granville Sharp. London, 1820.

Hochschild, Adam. Bury the Chains: Prophets and Rebels in the Fight to Free an Empire's Slaves. New York: Houghton Mifflin Co., 2005. 
Humphrey, Carol Sue. Voices of Revolutionary America: Contemporary Accounts of Daily Life. Santa Barbara, California: Greenwood, 2011.

Hurd, John C. The Law of Freedom and Bondage in the United States. New York: Negro Universities Press, 1968.

Jeffrey, Julie Roy. The Great Silent Army of Abolitionism: Ordinary Women in the Antislavery Movement. Chapel Hill: University of North Carolina Press, 1998.

Jenkins, William Sumner. Pro-slavery thought in the Old South. Gloucester, Mass: P. Smith, 1960.

Johnson, Paul E. A Shopkeeper's Millennium: Society and Revivals in Rochester, New York, 1815-1837. New York: Hill and Wang, 2004.

Johnson, Paul E., and Sean Wilentz. The Kingdom of Matthias. New York: Oxford University Press, 1994.

Johnson, Walter. The Chattel Principle: Internal Slave Trades in the Americas. New Haven, CT: Yale University Press, 2004.

Jones, Howard. Abraham Lincoln and a New Birth of Freedom: The Union and Slavery in the Diplomacy of the Civil War. Lincoln: University of Nebraska Press, 1999.

Jordan, Winthrop D. White Over Black: American Attitudes Toward the Negro, 15501812. Chapel Hill: Published for the Institute of Early American History and Culture at Williamsburg, Va., by the University of North Carolina Press, 1968.

Kann, Mark E. The Gendering of American Politics: Founding Mothers, Founding Fathers, and Political Patriarchy. Westport, Conn: Praeger, 1999.

Kantrowitz, Stephen David. More Than Freedom: Fighting for Black Citizenship in a White Republic, 1829-1889. New York: Penguin Press, 2012.

Ketcham, Ralph. James Madison; A Biography. New York, N.Y.: Macmillan, 1971.

Lerner, Gerda. The Grimké Sisters from South Carolina: Pioneers for Women's Rights and Abolition. Chapel Hill: University of North Carolina Press, 2004.

Lumpkin, Katharine Du Pre. The Emancipation of Angelina Grimké. Chapel Hill: University of North Carolina Press, 1974.

Maffly-Kipp, Laurie F. Setting Down the Sacred Past: African-American Race Histories. Cambridge, Mass: Belknap Press of Harvard University Press, 2010. 
Madison, James, Merrill D. Peterson, and James Madison. James Madison: A Biography in His Own Words. New York: Newsweek, 1974.

Magrath, C. Peter, Robert Fletcher, and John Peck. Yazoo: Law and Politics in the New Republic: The Case of Fletcher V. Peck. New York: Norton, 1967.

McCowen, George Smith. The British Occupation of Charleston, 1780-82. 1972.

McKissack, Pat, and Fredrick McKissack. Sojourner Truth: Ain't I a Woman? New York: Scholastic, 1992.

Morgan, Edmund S. American Slavery, American Freedom: The Ordeal of Colonial Virginia. New York: Norton, 1975.

Morgan, Kenneth. Slavery and Servitude in Colonial North America: A Short History. Washington Square, N.Y.: New York University Press, 2001.

Nash, Gary B. Forging Freedom: The Formation of Philadelphia's Black Community, 1720-1840. Cambridge, Mass: Harvard University Press, 1988.

Nederveen Pieterse, Jan. White on black: images of Africa and Blacks in Western popular culture. New Haven: Yale University Press, 1992.

Neely, Mark E. The Civil War and the Limits of Destruction. Cambridge, Mass: Harvard University Press, 2007.

Nelson, Megan Kate. Ruin Nation: Destruction and the American Civil War. Athens: University of Georgia Press, 2012.

Newman, Richard S. The Transformation of American Abolitionism: Fighting Slavery in the Early Republic. Chapel Hill: University of North Carolina Press, 2002.

Noll, Mark A. The Civil War as a Theological Crisis. Chapel Hill: University of North Carolina Press, 2006.

O'Kane-Lipartito, Elizabeth. "The Misfortunes and Calamities of War": Civilians and Society in the American Revolution and After, 1775-1830, Unpublished Dissertation, University of Houston, 1993.

Oldfield, J. R. Transatlantic Abolitionism in the Age of Revolution: An International History of Anti-Slavery, C.1787-1820. 2013. 
Oshatz, Molly. Slavery and Sin: The Fight against Slavery and the Rise of Liberal Protestantism. New York: Oxford University Press, 2012.

Pagden, Anthony. Lords of All the World: Ideologies of Empire in Spain, Britain and France C. 1500-C. 1800. New Haven, Conn: Yale University Press, 1995.

Painter, Nell Irvin. Sojourner Truth: A Life, a Symbol. 1996.

Perry, Lewis. Radical Abolitionism: Anarchy and the Government of God in Antislavery Thought. Knoxville: University of Tennessee Press, 1995.

Patterson, Orlando. Slavery and Social Death: A Comparative Study. Cambridge, Mass: Harvard University Press, 1982.

Raboteau, Albert J. A Fire in the Bones: Reflections on African-American Religious History. Boston: Beacon Press, 1995.

Slave Religion: The "Invisible Institution" in the Antebellum South. New York: Oxford University Press, 1978.

Rael, Patrick. Black identity and Black protest in the antebellum North. Chapel Hill, University of North Carolina Press, 2002.

Rosen, Gary. American Compact: James Madison and the Problem of Founding. Lawrence, Kan: University Press of Kansas, 1999.

Rothman, Adam. Slave Country: American Expansion and the Origins of the Deep South. Cambridge, Mass: Harvard University Press, 2005.

Ruchames, Louis, ed. The Letters of William Lloyd Garrison, vol. 2: A House Dividing Against Itself, 1836-1840. Cambridge: Harvard University Press, 1971.

Rutland, Robert Allen. James Madison: The Founding Father. 1987.

Saillant, John. Black Puritan, Black Republican: The Life and Thought of Lemuel Haynes, 1753-1833. Oxford: Oxford University Press, 2003.

Seyda, Barbara and Nicholas Wright. Celia, a Slave. New Haven: Yale University Press, 2016.

Schantz, Mark S. Awaiting the Heavenly Country: The Civil War and America's Culture of Death. Ithaca: Cornell University Press, 2008.

Sinha, Manisha. The Slave's Cause: A History of Abolition. 2016. 
Slaughter, Thomas P. The Beautiful Soul of John Woolman, Apostle of Abolition. New York: Hill and Wang, 2008.

Smithers, Gregory D. Slave Breeding: Sex, Violence, and Memory in African American History. 2012.

Soderlund, Jean R. Quakers \& Slavery: A Divided Spirit. Princeton, N.J.: Princeton University Press, 1985.

Speicher, Anna M. The Religious World of Antislavery Women: Spirituality in the Lives of Five Abolitionist Lecturers. New York: Syracuse University Press, 2000.

Stauffer, John. The Black Hearts of Men: Radical Abolitionists and the Transformation of Race. Cambridge, Mass: Harvard University Press, 2002.

Stewart, David O. The Summer of 1787: The Men Who Invented the Constitution. New York: Simon \& Schuster, 2007.

Stewart, Maria W., and Marilyn Richardson. Maria W. Stewart, America's First Black Woman Political Writer: Essays and Speeches. Bloomington: Indiana University Press, 1987.

Striner, Richard. Father Abraham: Lincoln's Relentless Struggle to End Slavery. Oxford: Oxford University Press, 2006.

Strong, Douglas M. Perfectionist Politics: Abolitionism and the Religious Tensions of American Democracy. Syracuse, N.Y.: Syracuse University Press, 1999.

Swift, David Everett. Black Prophets of Justice: Activist Clergy Before the Civil War. Baton Rouge: Louisiana State University Press, 1989.

Tadman, Michael. Speculators and Slaves: Masters, Traders, and Slaves in the Old South. Madison, Wis: University of Wisconsin Press, 1989.

Tackach, James. Lincoln's Moral Vision: The Second Inaugural Address. Jackson: University Press of Mississippi, 2002.

Thomas, Benjamin Platt. Theodore Weld, Crusader for Freedom. New York: Octagon Books, 1973.

Thomas, John L. The Liberator, William Lloyd Garrison: A Biography. Boston: Little, Brown and Company, 1963.

Torrey, Jesse. A Portraiture of Domestic Slavery, in the United States: With Reflections on the Practicability of Restoring the Moral Rights of the Slave, Without Impairing the 
Legal Privileges of the Possessor; and a Project of a Colonial Asylum for Free Persons of Colour: Including Memoirs of Facts on the Interior Traffic in Slaves, and on Kidnapping. St. Clair Shores, Mich: Scholarly Press, 1970.

Tucker, Robert W., and David C. Hendrickson. The Fall of the First British Empire: Origins of the War of American Independence. Baltimore: Johns Hopkins University Press, 1982.

United States, Max Farrand, and David Maydole Matteson. The Records of the Federal Convention of 1787. New Haven: Yale University Press, 1986.

Van Cleve, George. A Slaveholders' Union: Slavery, Politics, and the Constitution in the Early American Republic. Chicago: University of Chicago Press, 2010.

Waldstreicher, David. Runaway America: Benjamin Franklin, Slavery, and the American Revolution. New York: Hill and Wang, 2004.

Walker, David, and Peter P. Hinks. David Walker's Appeal to the Coloured Citizens of the World. University Park, Pa: Pennsylvania State University Press, 2000.

Wallis, Jim. America's Original Sin: Racism, White Privilege, and the Bridge to a New America. 2016.

White, Deborah G. Ar'n't I a Woman?: Female Slaves in the Plantation South. New York: W.W. Norton, 1999.

Wilentz, Sean. Andrew Jackson. New York: Times Books, 2005.

Williams, Eric Eustace. Capitalism \& Slavery. New York: Capricorn Books, 1944, 1966.

Windley, Lathan A. Runaway Slave Advertisements: A Documentary History from the 1730s to 1790. Westport, Conn: Greenwood Press, 1983.

Wood, Kirsten E. Masterful Women: Slaveholding Widows from the American Revolution Through the Civil War. Chapel Hill: University of North Carolina Press, 2004.

Wright, Gavin. Slavery and American Economic Development. Baton Rouge: Louisiana State University Press, 2006.

. The Political Economy of the Cotton South: Households, Markets, and Wealth in the Nineteenth Century. New York: Norton, 1978.

Wyatt-Brown, Bertram. Lewis Tappan and the Evangelical War against Slavery. New York: Atheneum, 1971. 
Yee, Shirley J. Black Women Abolitionists: A Study in Activism, 1828-1860. Knoxville: University of Tennessee Press, 1992.

Yellin, Jean Fagan, and John C. Van Horne. The Abolitionist Sisterhood: Women's Political Culture in Antebellum America. Ithaca: Cornell University Press, 1994.

Zaeske, Susan. Signatures of Citizenship: Petitioning, Antislavery, and Women's Political Identity. Chapel Hill: University of North Carolina Press, 2003.

\section{Articles}

Brown, Lois A. "William Lloyd Garrison and Emancipatory Feminism in NineteenthCentury America, "In William Lloyd Garrison at Two Hundred, edited by STEWART JAMES BREWER, 41-76, Yale University Press, 2008.

Coffey, John. Aug. “'Tremble Britannia!': Fear, Providence and the Abolition of the Slave Trade, 1758-1807." English Historical Review, Vol. CXXVII, No. 527. Oxford University Press, 2012.

Lasser, Carol. "Voyeuristic Abolitionism: Sex, Gender, and the Transformation of Antislavery Rhetoric," Journal of the Early Republic 28, no. 1 (2008).

Lowe, Richard G. and Randolph B. Campbell, "The Slave-Breeding Hypothesis: A Demographic Comment on the "Buying" and "Selling" States." The Journal of Southern History 42, no. 3 (1976).

May, Nicholas. "Holy Rebellion: Religious Assembly Laws in Antebellum South Carolina and Virginia," The American Journal of Legal History 49, no. 3 (2007).

Minkema, Kenneth P. and Harry S. Stout in "The Edwardsean Tradition and the Antislavery Debate, 1740-1865," The Journal of American History 92, (June, 2005).

Schultz, Stanley K. "The Making of a Reformer: The Reverend Samuel Hopkins as an Eighteenth-Century Abolitionist," Proceedings of the American Philosophical Society 5 (Oct. 15, 1971).

Walters, Ronald. "The Erotic South: Civilization and Sexuality in American Abolitionism,” American Quarterly 25, May 1973. 
VITA

RICHARD RODRIGUEZ

Born in New York, New York

ACADEMIC HISTORY

$1981-1987$

B.A. History

Florida Atlantic University

Boca Raton, Florida

2008-2010

M.A. U.S. History

Florida International University

Miami, Florida

$2015-2017$

Doctoral Candidate

Florida International University

Miami, Florida

\section{PRESENTATIONS}

Paper Presentation, "The Fearful Penalties of God's Broken Law"

Memphis University Graduate Student Conference in African-American History (Feb.

2015)

Paper Presentation, "The Fearful Penalties of God's Law"

Florida International University Graduate Student Conference (Mar. 2017) 